\author{
UNIVERSIDADE DE SÃO PAULO \\ ESCOLA DE ENGENHARIA DE SÃO CARLOS \\ DEPARTAMENTO DE GEOTECNIA
}

\title{
Influência da contaminação por cloreto de cobre na resistência ao cisalhamento de solos utilizados em liners
}

DANILO PACHECO E SILVA

Dissertação apresentada à Escola de Engenharia de São Carlos da Universidade de São Paulo, como parte dos requisitos para a obtenção do título de Mestre em Geotecnia.

ORIENTADOR: PROF. DR. EDMUNDO ROGÉRIO ESQUIVEL

São Carlos - SP

2005 
Dedico este trabalho aos meus pais (meus ídolos) José Carlos e Renata, meus educadores e professores na escola da vida. Aos meus irmãos Mauricio e Viviane, pela amizade e companhia durante toda a minha vida. À Juliana, minha esposa e fonte inspiradora. 


\section{AGRADECIMENTOS}

À Escola de Engenharia de São Carlos e ao Departamento de Geotecnia pela oportunidade de realizar esta pesquisa.

Ao CNPq - Conselho Nacional de Desenvolvimento Científico e Tecnológico, pela bolsa de mestrado concedida.

Ao Prof. Dr. Edmundo Rogério Esquivel pela orientação, companheirismo e rigor nas correções.

Aos funcionários do Departamento de Geotecnia, Oscar, Décio, Herivelto, Toninho, Maristela, Álvaro, Neiva, Cléver e Benedito pela atenção. E em especial ao Sr. Antonio e ao José Luis pela amizade e grande contribuição que prestaram a este trabalho.

Aos amigos da turma, Sergião, Adelvan, Angelita, Josieli, Vanessa e Luciene. Em especial ao Francis (China) e ao Thiago (Miséria) pela amizade sincera que compartilhamos desde a época da graduação.

Ao Roger e ao Heraldo, que além de amigos, foram incentivadores e conselheiros durante a realização deste trabalho.

Em especial à Juliana, minha esposa, pelo seu amor, compreensão e incentivo nesta importante fase de minha vida.

A Deus, pois sem ele nada seria possível. 
“Às vezes parece muito dificil viver neste mundo. É preciso considerar o modo como as criaturas enfrentam as diversidades e como buscam a solução de seus problemas. A solução desses momentos difíceis nunca está no desespero, na revolta e nas atitudes impensadas, mas na inteligência, na serenidade, na coragem, no bom senso dos pensamentos e atitudes, na determinação de vencer. A diferença entre o possível e o impossível, na maioria das vezes, é questão de persistência e determinação".

Autor Desconhecido 


\section{SUMÁRIO}

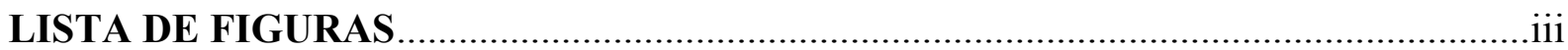

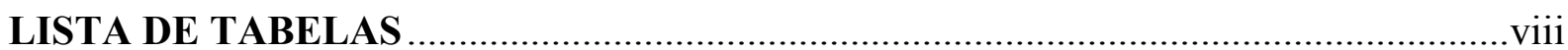

LISTA DE ABREVIATURAS, SIGLAS E SÍMBOLOS ...........................................

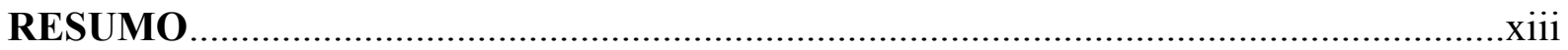

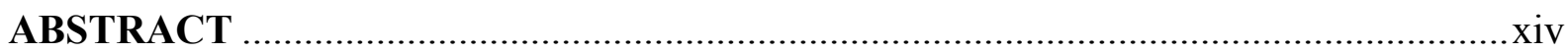

1.INTRODUÇÃO

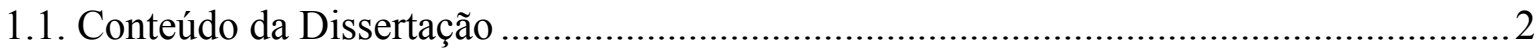

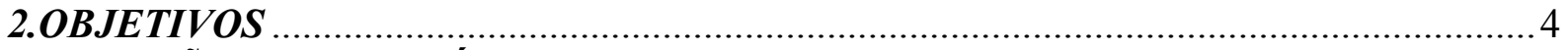

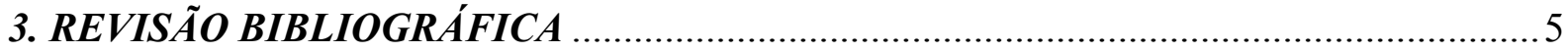

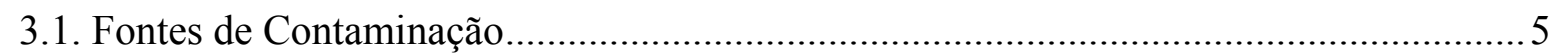

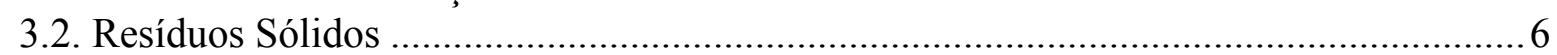

3.2.1. Definição e Classificação ............................................................................ 6

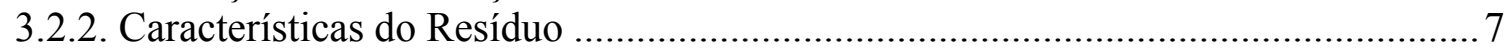

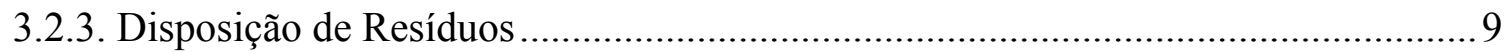

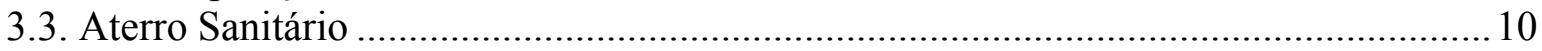

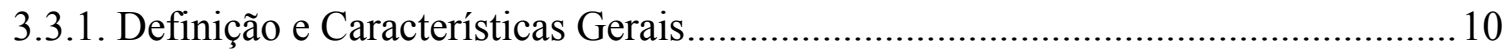

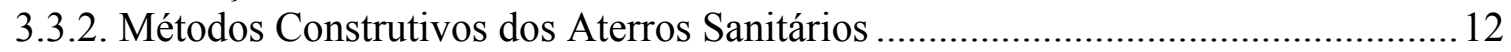

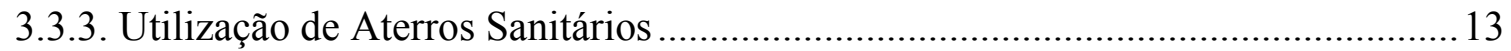

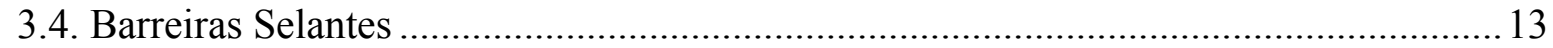

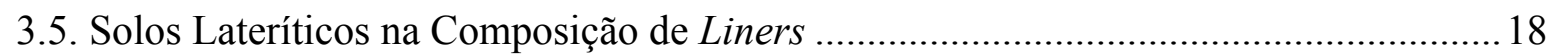

3.6. Mecanismos Físicos de Transporte de Contaminantes.................................................20

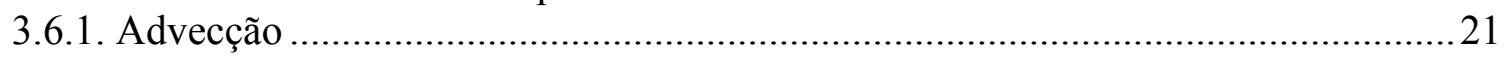

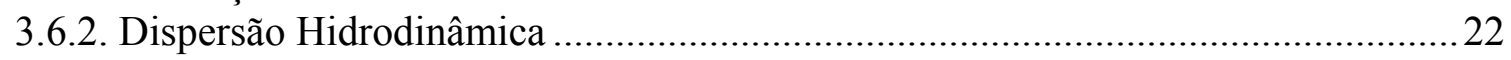

3.6.3. Mecanismo Final de Transporte de Contaminantes ............................................25

3.7. Interação entre o Solo e a Solução Contaminante .........................................................26

3.7.1. Influência das Cargas Elétricas no Comportamento do Solo .................................27

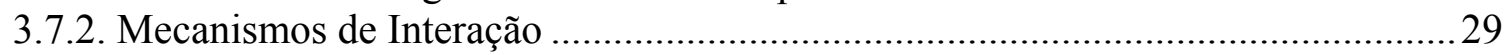

3.8. Realização do Transporte e Adsorção de Contaminantes em Laboratório...................... 32

3.8.1. Parâmetros Obtidos com a Realização dos Ensaios de Percolação em Colunas ....33

3.9. Condutividade Hidráulica dos Solos Utilizados em Liners ............................................ 34

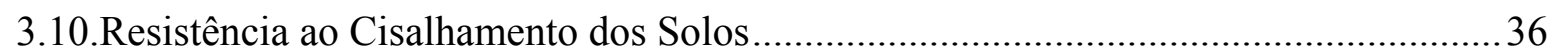

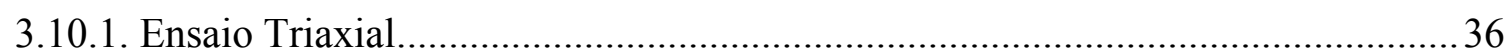

3.10.2. Saturação por Contra Pressão .......................................................................... 38

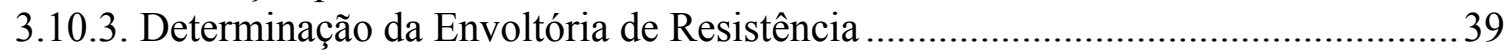

3.11. Comportamento Mecânico de Solos Contaminados....................................................... 41

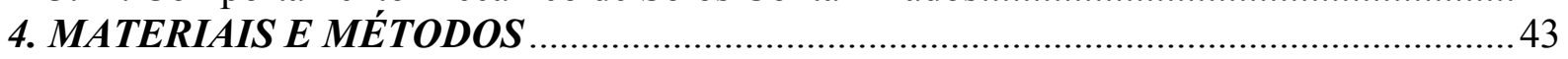

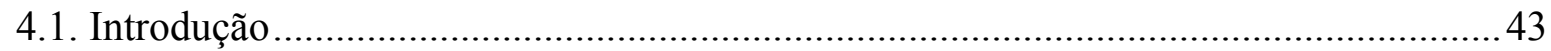

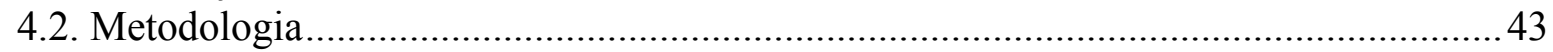

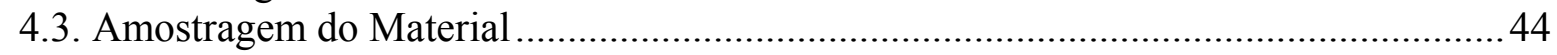

4.4. Preparação da Mistura ................................................................................................... 46

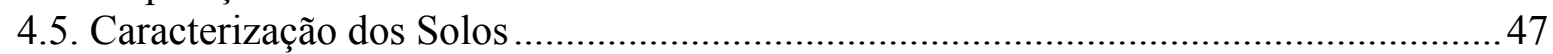

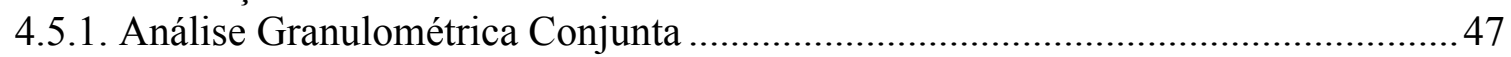

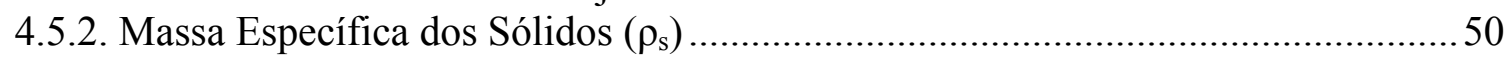

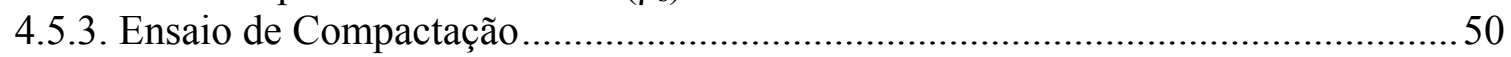

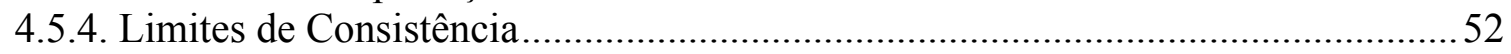

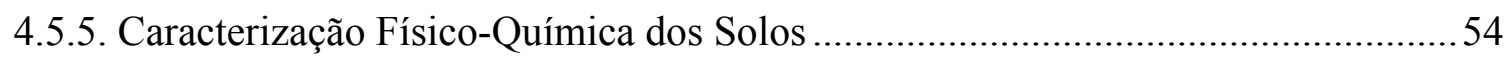

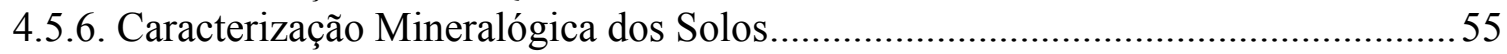


4.5.7. Comentários com Relação à Caracterização dos Solos .......................................... 55

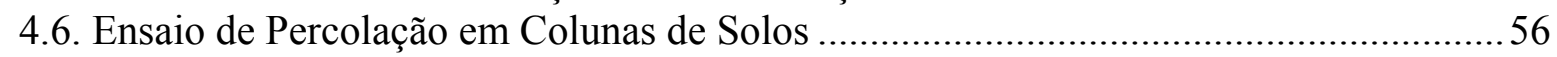

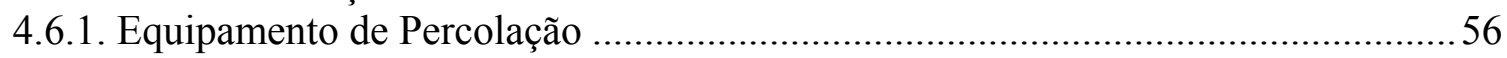

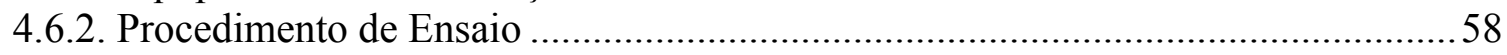

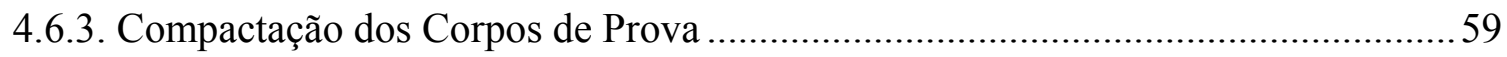

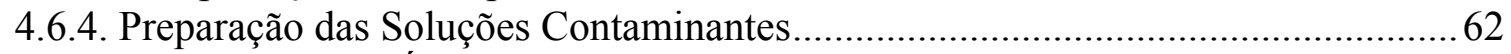

4.6.5. Percolação com Água Destilada e Contaminante...................................................6 63

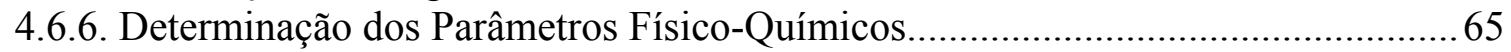

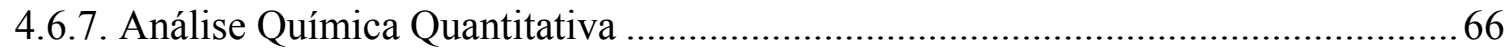

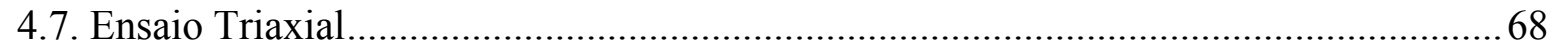

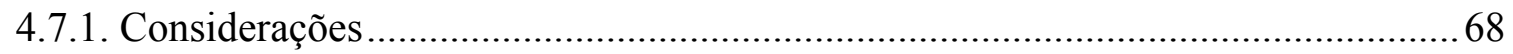

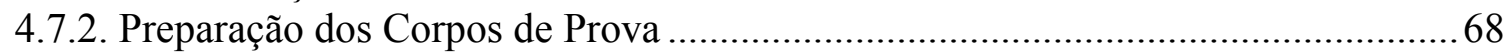

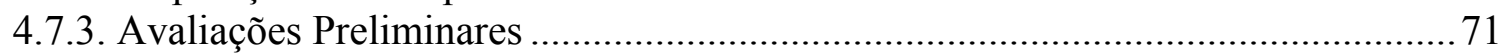

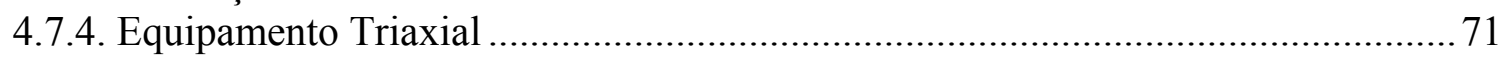

4.7.5. Procedimento de Ensaio .................................................................................. 73

4.7.6. Correção da área do corpo de prova no Ensaio Triaxial........................................... 79

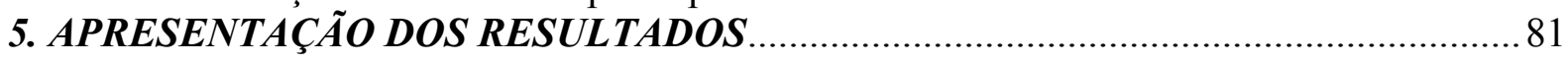

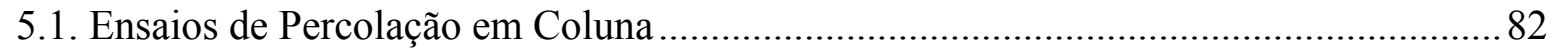

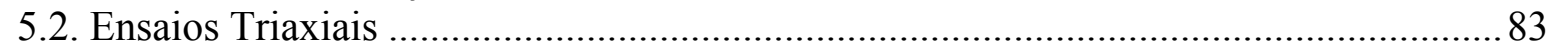

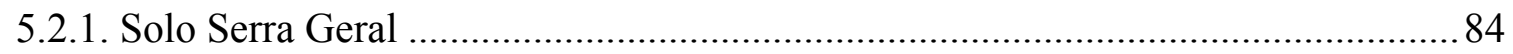

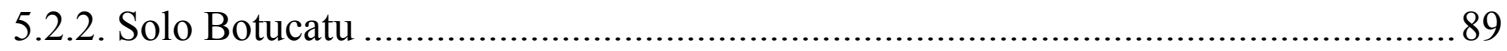

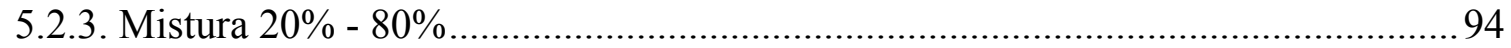

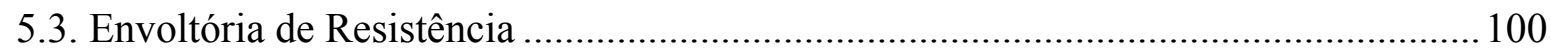

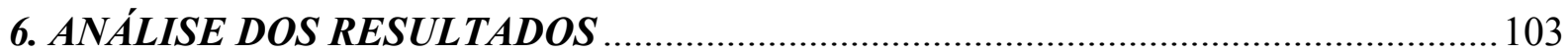

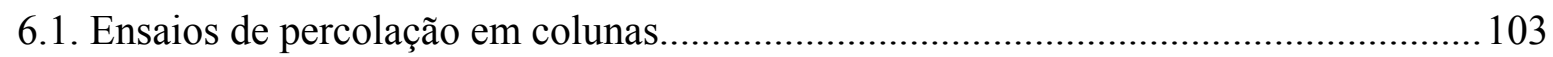

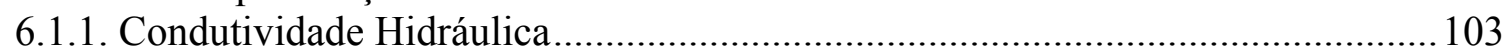

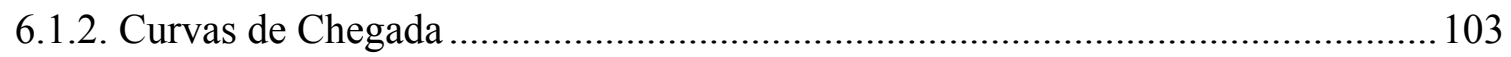

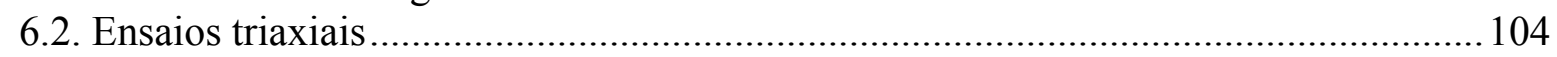

6.2.1. Parâmetros de Resistência em Função da Concentração....................................... 109

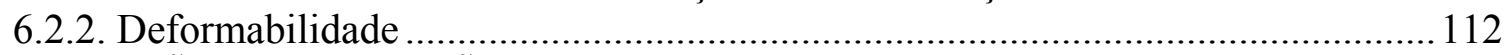

7.CONCLUSÕES E SUGESTÕES PARA PESQUISAS FUTURAS ............................. 115

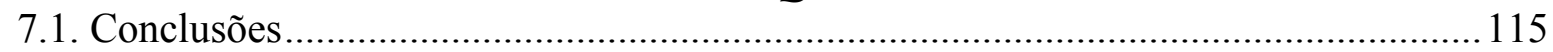

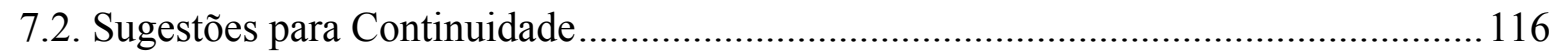

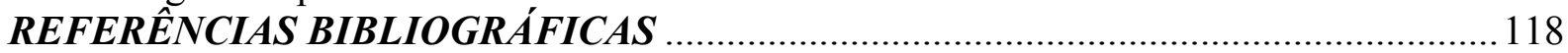

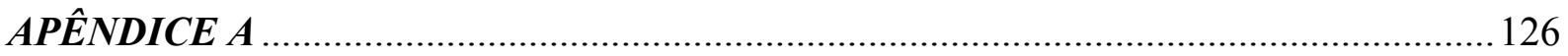

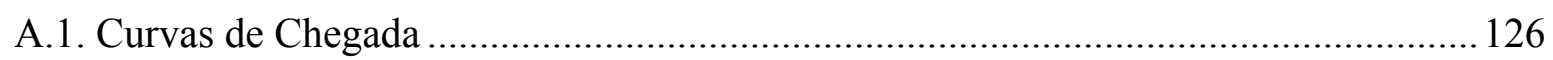

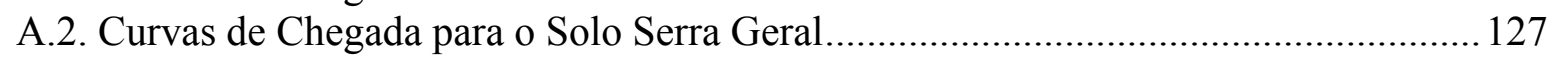

A.3. Curvas de Chegada para o Solo Botucatu................................................................... 130

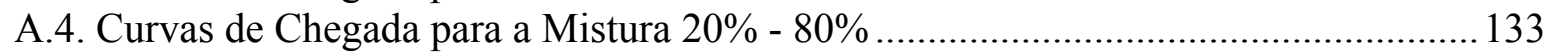




\section{LISTA DE FIGURAS}

Figura 3.1. Interações existentes entre as fontes poluidoras, o solo e as águas subterrâneas. 6

Figura 3.2. Elementos constituintes do aterro sanitário (Instituto de Pesquisas Tecnológicas - IPT, 1995) 12

Figura 3.3 (a). Configurações de liners (SHARMA; LEWIS, 1994). 15

Figura 3.3 (b). Configurações de liners (SHARMA; LEWIS, 1994). .15

Figura 3.4. Talude lateral de liners construído em camadas paralelas (a) e horizontais (b) (DANIEL, 1993).

Figura 3.5. Distribuição dos solos lateríticos no Brasil (MELFI, 1994).

Figura 3.6. Representação do transporte de contaminante por advecção (SHARMA; LEWIS, 1994). 22

Figura 3.7. Representação do transporte de contaminante por dispersão hidrodinâmica

( SHARMA; LEWIS, 1994).

Figura 3.8. Fatores que interferem no transporte por dispersão mecânica no solo.(SCHALCKELFORD, 1993 - modificado).

Figura 3.9. Formação da dupla camada elétrica e dupla camada difusa junto à superfície de uma partícula com cargas negativas (MITCHELL, 1993).

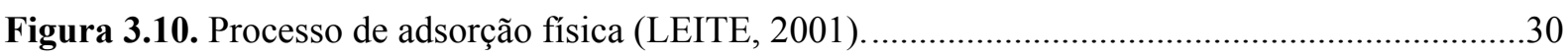

Figura 3.11. Processo de troca iônica (YONG et al.,1992).

Figura 3.12. Tipos de curvas de chegada: (a) soluto não reativo - transporte advectivo; (b) soluto reativo - efeito da dispersão hidrodinâmica (FREEZE; CHERRY, 1979 - modificado). .33

Figura 3.13. Plano de ruptura nos aterros escavados (SHARMA; LEWIS, 1994). ...............................36

Figura 3.14. Esquema típico de um ensaio triaxial (BARDET, 1997) ...................................................

Figura 3.15. Fluxograma que sintetiza os tipos de ensaio triaxial. ......................................................38

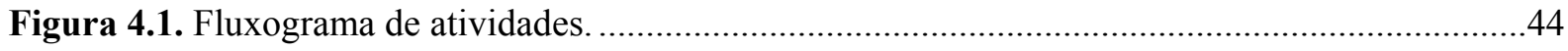

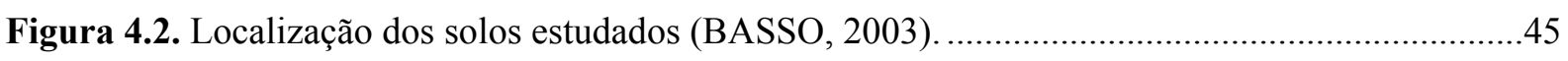

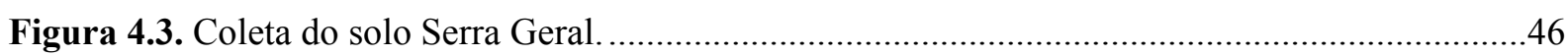

Figura 4.4. Mineração Itaporanga: local de coleta do solo Botucatu. ...................................................46

Figura 4.5. Curva de distribuição granulométrica para o solo Serra Geral. ............................................48

Figura 4.6. Curva de distribuição granulométrica para o solo Botucatu.................................................48

Figura 4.7. Curva de distribuição granulométrica para a mistura. .........................................................49

Figura 4.8. Curva de compactação Proctor Normal para o solo Serra Geral. .......................................51

Figura 4.9. Curva de compactação Proctor Normal para o solo Botucatu. ............................................51

Figura 4.10. Curva de compactação Proctor Normal para a mistura. ……...........................................52

Figura 4.11. Curva de fluência para determinação do limite de liquidez para o solo Serra Geral........53

Figura 4.12. Curva de fluência para determinação do limite de liquidez para a Mistura.......................54

Figura 4.13. Equipamento utilizado para a realização dos ensaios de percolação em colunas..............57 
Figura 4.14. Procedimento de ensaio de percolação em coluna de solo (DANIEL, 1993 modificado) 58

Figura 4.15. Compactador dinâmico. .60

Figura 4.16.Milivoltímetro utilizado para a determinação do $E h$. .65

Figura 4.17. pHmetro utilizado para a determinação do $p H$. .65

Figura 4.18. Condutivímetro utilizado para a determinação da condutividade elétrica. .66

Figura 4.19. Espectrofotômetro visível $\mathrm{HACH}$.

Figura 4.20. Detalhe da amostra no interior de um erlenmeyer e sobre um agitador magnético, durante sua titulação utilizando-se o nitrato de prata.

Figura 4.21. Retirada de amostras por meio de extrator.

Figura 4.22. Detalhe da caixa metálica utilizada para a retirada do corpo de prova Serra Geral..........69

Figura 4.23. Processo de talhagem do topo e da base do corpo de prova. ...........................................70

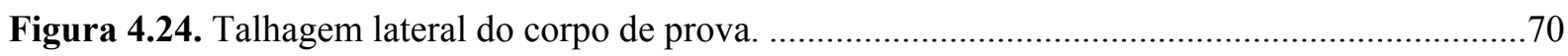

Figura 4.25. Corpos de prova condicionados no interior de um dessecador........................................ 71

Figura 4.26. Esquema do equipamento utilizado para realizar os ensaios triaxiais. ..............................72

Figura 4.28. Corpo de prova após sua montagem para a realização do ensaio triaxial..........................74

Figura 4.29. Equipamento utilizado para a medição da variação de volume.........................................78

Figura 4.30. Determinação de $t_{100}$ a partir do gráfico de adensamento.................................................78

Figura 5.1. Curvas de Variação volumétrica (\%) versus $1 t$, sendo o tempo em minutos......................84

Figura 5.2. Curvas de Tensão desvio versus Deformação axial. ..........................................................84

Figura 5.3. Curvas de Pressão neutra versus Deformação axial........................................................85

Figura 5.4. Curvas de Variação volumétrica (\%) versus $1 t$, sendo o tempo em minutos......................85

Figura 5.5. Curvas de Tensão desvio versus Deformação axial. .........................................................86

Figura 5.6. Curvas de Pressão neutra versus Deformação axial.........................................................86

Figura 5.7. Curvas de Variação volumétrica (\%) versus ${ }^{t}$, sendo o tempo em minutos......................87

Figura 5.8. Curvas de Tensão Desvio versus Deformação axial............................................................87

Figura 5.9. Curvas de Pressão neutra versus Deformação axial. ..........................................................87

Figura 5.10. Curvas de Variação volumétrica (\%) versus ${ }^{t}$, sendo o tempo em minutos....................88

Figura 5.11. Curvas de Tensão desvio versus Deformação axial. ........................................................8

Figura 5.12. Curvas de Pressão neutra versus Deformação axial......................................................89

Figura 5.13. Curvas de Variação volumétrica (\%) versus 1 t, sendo o tempo em minutos...................89

Figura 5.14. Curvas de Tensão desvio versus Deformação axial. .....................................................90

Figura 5.15. Curvas de Pressão neutra versus Deformação axial......................................................90

Figura 5.16. Curvas de Variação volumétrica (\%) versus ${ }^{t}$, sendo o tempo em minutos...................91

Figura 5.17. Curvas de Tensão desvio versus Deformação axial. .......................................................91

Figura 5.18. Curvas de Pressão neutra versus Deformação axial.....................................................91 
Figura 5.19. Curvas de Variação volumétrica (\%) versus $1 t$, sendo o tempo em minutos. .92

Figura 5.20. Curvas de Tensão Desvio versus Deformação axial .92

Figura 5.21. Curvas de Pressão neutra versus Deformação axial. .93

Figura 5.22. Curvas de Variação volumétrica (\%) versus $1 t$, sendo o tempo em minutos. .93

Figura 5.23. Curvas de Tensão desvio versus Deformação axial. .......................................................94

Figura 5.24. Curvas de Pressão neutra versus Deformação axial.......................................................94

Figura 5.25. Curvas de Variação volumétrica (\%) versus $v_{t}$, sendo o tempo em minutos...................95

Figura 5.26. Curvas de Tensão desvio versus Deformação axial. ......................................................95

Figura 5.27. Curvas de Pressão neutra versus Deformação axial.......................................................95

Figura 5.28. Curvas de Variação volumétrica (\%) versus 1 t, sendo o tempo em minutos....................96

Figura 5.29. Curvas de Tensão desvio versus Deformação axial ........................................................96

Figura 5.30. Curvas de Pressão neutra versus Deformação axial......................................................97

Figura 5.31. Curvas de Variação volumétrica (\%) versus ${ }^{t}$, sendo o tempo em minutos...................97

Figura 5.32. Curvas de Tensão desvio versus Deformação axial. .......................................................98

Figura 5.33. Curvas de Pressão neutra versus Deformação axial..........................................................98

Figura 5.34. Curvas de Variação volumétrica (\%) versus $1 t$, sendo o tempo em minutos...................99

Figura 5.35. Curvas de Tensão desvio versus Deformação axial. ......................................................99

Figura 5.36. Curvas de Pressão neutra versus Deformação axial.....................................................99

Figura 5.37. Envoltórias de resistência em termos de tensões totais - solo Serra Geral. .....................100

Figura 5.38. Envoltórias de resistência em termos de tensões efetivas - solo Serra Geral. .................100

Figura 5.39. Envoltórias de resistência em termos de tensões totais - solo Botucatu. ........................101

Figura 5.40. Envoltórias de resistência em termos de tensões efetivas - solo Botucatu. ......................101

Figura 5.41. Envoltórias de resistência em termos de tensões totais - mistura. ..................................101

Figura 5.42. Envoltórias de resistência em termos de tensões efetivas - mistura. ................................102

Figura 6.1. Tensão desvio na ruptura em função da concentração do contaminante para os três solos, confinados com $50 \mathrm{kPa}$. 106

Figura 6.2. Tensão desvio na ruptura em função da concentração do contaminante para os três solos, confinados com $100 \mathrm{kPa}$. 106

Figura 6.3. Tensão desvio na ruptura em função da concentração do contaminante para os três solos, confinados com $200 \mathrm{kPa}$..

Figura 6.4. Valores relativos da tensão desvio de ruptura em função da concentração do contaminante, para os três solos, confinados com $50 \mathrm{kPa}$.

Figura 6.5. Valores relativos da tensão desvio de ruptura em função da concentração do contaminante, para os três solos, confinados com $100 \mathrm{kPa}$.

Figura 6.6. Valores relativos da tensão desvio de ruptura em função da concentração do contaminante, para os três solos, confinados com $200 \mathrm{kPa}$. 108 
Figura 6.7. Variação da coesão total com a concentração do contaminante. 110

Figura 6.8. Variação da coesão efetiva com a concentração do contaminante. 110

Figura 6.9. Variação do ângulo de atrito total com a concentração do contaminante. 110

Figura 6.10. Variação do ângulo de atrito efetivo com a concentração do contaminante.

Figura 6.11. Variação do módulo de deformabilidade $\left(E_{50}\right)$ com a concentração de contaminante para o solo Serra Geral.

Figura 6.12. Variação do módulo de deformabilidade $\left(E_{50}\right)$ com a concentração de contaminante para o solo Botucatu...

Figura 6.13. Variação do módulo de deformabilidade $\left(E_{50}\right)$ com a concentração de contaminante para a mistura. 114

Figura A1. Curva de chegada para a amostra 04. 127

Figura A2. Curva de chegada para a amostra 05. 127

Figura A3. Curva de chegada para a amostra 06. 128

Figura A4. Curva de chegada para a amostra 07. 128

Figura A5. Curva de chegada para a amostra 08. 128

Figura A6. Curva de chegada para a amostra 09. 129

Figura A7. Curva de chegada para a amostra 10. 129

Figura A8. Curva de chegada para a amostra 11. 129

Figura A9. Curva de chegada para a amostra 12. 130

Figura A10. Curva de chegada para a amostra 04. 130

Figura A11. Curva de chegada para a amostra 05 131

Figura A12. Curva de chegada para a amostra 06 131

Figura A13. Curva de chegada para a amostra 07 131

Figura A14. Curva de chegada para a amostra 08 132

Figura A15. Curva de chegada para a amostra 09 132

Figura A16. Curva de chegada para a amostra 10 132

Figura A17. Curva de chegada para a amostra 11 133

Figura A18. Curva de chegada para a amostra 12 133

Figura A19. Curva de chegada para a amostra 04. 134

Figura A20. Curva de chegada para a amostra 05 134

Figura A21. Curva de chegada para a amostra 06 134

Figura A22. Curva de chegada para a amostra 07 135

Figura A23. Curva de chegada para a amostra 08 135

Figura A24. Curva de chegada para a amostra 09 135

Figura A25. Curva de chegada para a amostra 10 136

Figura A26. Curva de chegada para a amostra 11 136 


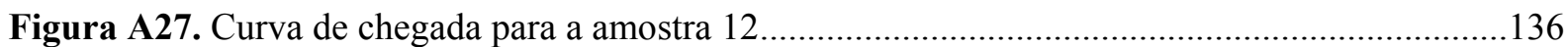




\section{LISTA DE TABELAS}

Tabela 3.1. Classificação dos resíduos sólidos quanto à periculosidade.

Tabela 3.2. Concentrações máximas detectadas em águas subterrâneas natural e contaminadas por ação humana (Água de mina) em mg/L ( MATHESS et al.,1985 - modificado)...

Tabela 3.3. Parâmetros que podem ser determinados a partir de ensaios de percolação em colunas. ..34

Tabela 4.1. Distribuição granulométrica em porcentagem de ocorrência para os três solos estudados, obtidos experimentalmente.

Tabela 4.2. Valores teóricos para cada fração granulométrica da mistura a partir dos resultados de granulometria conjunta dos solos Serra Geral e Botucatu.

Tabela 4.3. Resultados médios da massa específica dos sólidos para os três solos. ..............................50

Tabela 4.4. Parâmetros de compactação para energia Proctor Normal. ................................................52

Tabela 4.5. Resultados de limites de consistência e índice de atividade..............................................54

Tabela 4.6. Propriedades físico-químicas dos solos estudados. .........................................................55

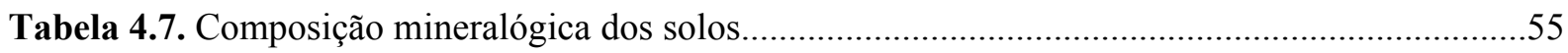

Tabela 4.8. Classificação dos solos pelo sistema unificado (SUCS) ....................................................56

Tabela 4.9. Dados referentes à compactação das amostras de solo Serra Geral. ....................................61

Tabela 4.10. Dados referentes à compactação das amostras de solo Botucatu. .....................................61

Tabela 4.11. Dados referentes à compactação das amostras da mistura. ...............................................62

Tabela 4.12. Massa de cloreto de cobre utilizado na preparação das soluções. ....................................63

Tabela 4.13. Parâmetros físico-químicos das Soluções...........................................................................63

Tabela 4.14. Constantes dos canais do sistema de aquisição. ............................................................73

Tabela 4.15. Estágios de saturação para o solo Serra Geral. ................................................................75

Tabela 4.16. Estágios de saturação para o solo Botucatu......................................................................76

Tabela 4.17. Estágios de saturação para a mistura. .........................................................................76

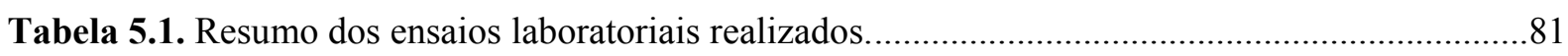

Tabela 5.2. Resultados do ensaio de percolação em colunas para o solo Serra Geral...........................82

Tabela 5.3. Resultado do ensaio de percolação em colunas para o solo Botucatu.................................82

Tabela 5.4. Resultados do ensaio de percolação em colunas para a mistura...........................................83

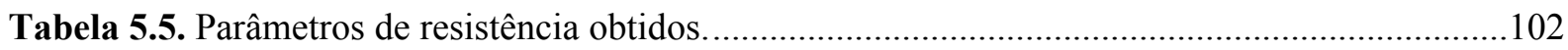

Tabela 5.6 - Módulo de deformabilidade secante a 50\% $\left(E_{50}\right)$ para solo Serra Geral.........................112

Tabela 5.7 - Módulo de deformabilidade secante a 50\% $\left(E_{50}\right)$ para solo Botucatu..............................112

Tabela 5.8 - Módulo de deformabilidade secante a $50 \%\left(E_{50}\right)$ para a mistura $20 \%-80 \%$...................113 


\section{LISTA DE ABREVIATURAS, SIGLAS E SÍMBOLOS}

$a=$ intercepto da envoltória no plano p-q

$\mathrm{A}=$ área da seção transversal do solo

$\mathrm{A}_{0}=$ área inicial do corpo de prova

$\mathrm{ABNT}=$ Associação Brasileira de Normas Técnicas

ASTM $=$ Association of Soil and Testing Materials

ATD $=$ análise térmica diferencial

ATG $=$ análise térmica gravimétrica

$B=$ parâmetro de Skempton

CETESB = Companhia de Tecnologia e de Saneamento Ambiental de São Paulo

$c=$ coesão do solo

$c^{\prime}=$ coesão efetiva do solo

$C=$ concentração

$\mathrm{CD}=$ adensado e drenado

$\mathrm{CE}=$ condutividade elétrica

$C_{p}=$ constante de permeabilidade

$C / C_{0}=$ concentração relativa

$C_{0}=$ concentração inicial

$C_{S}=$ concentração do soluto

$\mathrm{CTC}=$ capacidade de troca catiônica

$\mathrm{CU}=$ adensado e não drenado

$D=$ diâmetro do corpo de prova

$d=$ distância percorrida

$D^{*}=$ coeficiente de difusão molecular efetiva

$d_{c}=$ diâmetro do canal do poro

$D_{h}=$ coeficiente de dispersão hidrodinâmica

$D_{m}=$ coeficiente de dispersão mecânica

$D_{0}=$ coeficiente de difusão molecular

$e=$ índice de vazios

$\mathrm{EB}=$ Ensaio Brasileiro

EESC $=$ Escola de Engenharia de São Carlos

Eh $=$ potencial de oxi-redução

$E_{50}=$ módulo de deformabilidade secante à $50 \%$ da tensão de ruptura 
$g=$ aceleração da gravidade

$G C=$ grau de compactação

GCL's = geocomposto bentonítico

$H=$ altura do corpo de prova

$h=$ diferença de carga entre duas faces livres do solo

$i=$ gradiente hidráulico

$I A=$ índice de atividade de Skempton

$I P=$ índice de plasticidade

$J_{A}=$ fluxo unidimensional de massa por advecção

$J_{D}=$ fluxo unidimensional de massa por difusão molecular

$J_{M}=$ fluxo unidimensional de massa por dispersão mecânica

$J_{T}=$ fluxo unidimensional de massa total

$k=$ condutividade hidráulica

$k_{\min }=$ condutividade hidráulica mínima

$k_{\text {méd }}=$ condutividade hidráulica média

$k_{\text {máx }}=$ condutividade hidráulica máxima

$k_{T}=$ condutividade hidráulica na temperatura do ensaio

$k_{20}=$ condutividade hidráulica a $20^{\circ} \mathrm{C}$

LDS $=$ sistema para escoamento do percolado

$\mathrm{LL}=$ limite de liquidez

$\mathrm{LP}=$ limite de plasticidade

$\mathrm{MB}=$ Método Brasileiro

MCT $=$ Miniatura, Compactado, Tropical

$M_{S}=$ massa de solo a ser compactado

$N=$ normalidade

$n=$ porosidade do solo

NBR $=$ Norma Brasileira Registrada

OMS = Organização Mundial da Saúde

$P=$ carga axial

$p=$ média das tensões principais totais

$p^{\prime}=$ média das tensões principais efetivas

$\mathrm{pH}=$ potencial hidrogeniônico

$P l=$ número de Peclet

$\mathrm{PVC}=$ cloreto polivinílico 
$Q=$ taxa de fluxo volumétrica (vazão)

$q=$ semi-diferença das tensões principais totais

$q^{\prime}=$ semi-diferença das tensões principais efetivas

$R_{d}=$ fator de retardamento

$\mathrm{SE}=$ superfície específica

SUCS $=$ Sistema Unificado de Classificação dos Solos

$S r=$ grau de saturação

$t=$ tempo decorrido

$t_{f}=$ tempo de ruptura

$T_{p}=$ número de volume de vazios percolados

$t_{100}=$ tempo para ocorrência de $100 \%$ do adensamento

$u=$ pressão neutra

USP $=$ Universidade de São Paulo

$\mathrm{UU}=$ não adensado e não drenado

UTM = Projeção Universal Transversa de Mercator

$v=$ velocidade de Darcy

$V_{a}=$ volume utilizado na titulação da amostra

$V_{b}=$ volume utilizado na titulação do branco

$V_{c}=$ volume da coluna

$V_{i}=$ volume da amostra

$V_{\text {máx }}=$ velocidade máxima de ensaio

$V_{p}=$ volume percolado

$v_{S}=$ velocidade de percolação

$V_{v}=$ volume de vazios

$V_{0}=$ volume inicial do corpo de prova

$x=$ direção do fluxo

$w_{c}=$ umidade de compactação

$w=$ teor de umidade

$w_{o t}=$ umidade ótima

$\phi=$ ângulo de atrito total

$\phi{ }^{\prime}=$ ângulo de atrito efetivo

$\alpha=$ declividade da envoltória no plano $\mathrm{p}-\mathrm{q}$

$\varepsilon=$ deformação axial 
$\varepsilon_{f}=$ deformação na ruptura

$\Delta w=$ desvio de umidade

$\Delta v_{i}=$ variação de volume do corpo de prova no instante $\mathrm{i}$

$\rho=$ massa específica

$\rho_{d}=$ massa específica seca

$\rho_{d m a ́ x}=$ massa específica seca máxima

$\rho_{s}=$ massa específica dos sólidos

$\mu=$ viscosidade dinâmica do fluído

$\mu_{T}=$ viscosidade dinâmica do fluído na temperatura do ensaio

$\mu_{20}=$ viscosidade dinâmica do fluído à temperatura de $20^{\circ} \mathrm{C}$

$\sigma_{3}=$ tensão de confinamento

$\sigma_{1-} \sigma_{3}=$ tensão desvio

$\sigma_{1-} \sigma_{3 \operatorname{máx}}=$ máxima tensão desvio

$\sigma^{\prime} 1 \sigma_{3}^{\prime}=$ razão máxima entre as tensões principais efetivas

$\sqrt{ } t=$ raiz quadrada do tempo 
SILVA, D.P. (2005) Influência da contaminação por cloreto de cobre na resistência ao cisalhamento de solos utilizados em liners. São Carlos, 2005. 136 p. Dissertação de Mestrado - Escola de Engenharia de São Carlos, Universidade de São Paulo.

\section{RESUMO}

Avaliou-se, experimentalmente, o efeito da contaminação, por uma solução de cloreto de cobre, na resistência ao cisalhamento de solos a serem utilizados na construção de liners. Foi escolhido o cloreto de cobre como contaminante pelo fato de os íons cobre serem os mais comuns nos aterros sanitários industriais. Apresentam-se resultados de ensaios de percolação em colunas e ensaios triaxiais convencionais do tipo CU para solos provenientes das Formações Serra Geral (argilosos), Botucatu (arenosos) e uma mistura dos mesmos na proporção de $20 \%$ de solo Serra Geral e $80 \%$ de solo Botucatu. A mistura apresentou condutividade hidráulica e resistência mais adequadas para utilização em liners do que cada um dos solos isolados. Da análise dos resultados dos ensaios triaxiais do tipo CU, constatouse a maior influência da contaminação no comportamento do solo Serra Geral, como conseqüência da dupla camada elétrica. Para os três solos, observou-se que o efeito da contaminação foi mais pronunciado para menores tensões confinantes.

Palavras-chave: resistência ao cisalhamento, contaminação, cloreto de cobre, liner, aterro sanitário. 
SILVA, D.P. (2005) Copper chloride contamination influence on the shear strength of soils used as liners. São Carlos, 2005. 136 p. Dissertação de Mestrado - Escola de Engenharia de São Carlos, Universidade de São Paulo.

\begin{abstract}
The contamination effects of copper chloride, on the shear strength of soils to be used as liners, were experimentally tested in laboratory. The copper chloride was chosen as the contaminant agent because it is the most common in found in industrial sanitary landfills. The results of percolation and conventional triaxial tests for soils from Serra Geral Formation (clayed soils), Botucatu Formation (sandy soils) and a mix in a convenient proportion with both soils are presented. The hydraulic condutivity and strength of the mixed soil indicated that it is more suitable to be used as liners than the original soils. From the comparison of triaxial test results, the effects of contamination were more significant in the soils from the Serra Geral Formation as a consequence of the electrical double layer. For the three soils, the effects of contamination were more noticeable for smaller confining pressures.
\end{abstract}

Key words: shear strength, contamination, copper chloride, liner, sanitary landfill. 


\section{INTRODUÇÃO}

Os primeiros resíduos sólidos gerados eram provenientes de materiais, em grande parte, de origem natural e a sua disposição inadequada não trazia sérias conseqüências. A partir da revolução industrial houve migrações populacionais para os centros urbanos. A geração de empregos e, conseqüentemente, o aumento do poder aquisitivo da população efetivaram o consumo dos produtos industrializados. A situação apenas agravou a necessidade de gerenciar os restos produzidos pela sociedade.

A disposição não planejada de resíduos pode provocar a degradação do meio ambiente. A construção de obras que tornem a disposição mais segura, obedecendo aos critérios técnicos de proteção ao meio ambiente é uma das formas de se evitar o problema. Neste sentido, a engenharia tenta contribuir, criando novas soluções técnicas que viabilizem tais propósitos, como por exemplo, os aterros sanitários. Assim, procura-se evitar cada vez mais os depósitos a céu aberto, lançamentos em rios e mares, convertendo tais locais de lixões a aterros sanitários controlados e seguros.

A importância deste assunto nos dias de hoje, faz com que várias pesquisas sejam realizadas para promover um avanço técnico-científico nesta área. Os aterros sanitários devem grande parte de seu desempenho à eficiência das barreiras protetoras (liners). Os liners são barreiras de contenção que visam proteger mananciais (superficiais ou subsuperficiais) e solos de líquidos contaminados, provenientes da decomposição da matéria orgânica e contaminantes inorgânicos, que se originam das mais variadas atividades humanas e ambientes urbanos.

Os solos tropicais, devido a sua existência em quase todo território brasileiro, são os materiais naturais mais disponíveis para a construção das barreiras impermeáveis (liners). Dentro deste grupo de solos, enquadram-se os originários das Formações Botucatu e Serra Geral. Estes solos ao serem analisados de forma isolada podem apresentar algumas desvantagens, como alta permeabilidade (Formação Botucatu) ou baixa resistência (Formação Serra Geral). Neste contexto, visando melhorias no comportamento mecânico das barreiras de contenção, realizou-se a mistura entre estes solos. A mistura foi constituída de $20 \%$ do solo proveniente da Formação Serra Geral e $80 \%$ do solo da Formação Botucatu. A escolha desta proporção teve como base o trabalho de Leite (1997), que verificou por meio de ensaios de percolação em colunas que a retenção do contaminante passa a ser efetivo a partir de $10 \%$ de acréscimo de solo da Formação Serra Geral no solo da Formação Botucatu. 
Algumas propriedades dos solos tropicais, relacionadas com a retenção de contaminantes, são atribuídas principalmente às frações silte e argila. Neste sentido, a segurança e a durabilidade das barreiras impermeáveis podem estar relacionadas com a interação solo-contaminante. O longo tempo de exposição do solo aos líquidos contaminantes pode condicionar alterações na sua estrutura e diferentes mecanismos de ruptura.

Torna-se necessário ampliar os critérios usuais para a seleção e utilização dos solos como liners. Além de considerar a condutividade hidráulica e os parâmetros de compactação, salienta-se a importância de avaliar a resistência ao cisalhamento do solo frente ao processo de contaminação.

O presente trabalho apresenta e discute os resultados de ensaios de compressão triaxial do tipo CU (adensado e não drenado) em solos compactados da Formação Serra Geral, Formação Botucatu e uma mistura entre ambos em dosagem pré-definida. As amostras de solo foram percoladas com água destilada e solução de cloreto de cobre aquoso, em diferentes concentrações, visando o estudo da influência do íon cobre na resistência do solo estudado. Empregou-se o cloreto de cobre como contaminante, pelo fato dos íons cobre serem os mais comuns nos aterros sanitários industriais. O processo de atenuação deste íon isolado permitiu quantificar sua influência na resistência ao cisalhamento de forma mais precisa, pois a presença de outros íons dificultaria esta análise específica.

Os dados obtidos, associados aos resultados já produzidos em outras pesquisas desenvolvidas no Departamento de Geotecnia, principalmente relacionadas aos parâmetros de transporte e retenção de poluentes, ampliaram o banco de dados em relação ao estudo desses materiais para utilização como liners.

\subsection{CONTEÚDO DA DISSERTAÇÃO}

Os objetivos que esta dissertação pretende atingir estão apresentados no Capítulo 2. O Capítulo 3 apresenta uma Revisão Bibliográfica sobre os principais tópicos relacionados ao tema desta pesquisa. Tentou-se apresentá-la dentro de uma seqüência natural de assuntos, com o intuito de torná-la mais didática, facilitando assim o seu entendimento.

O Capítulo 4 está relacionado com os materiais e métodos utilizados. Este capítulo apresenta a seqüência adotada para a realização das etapas experimentais, bem como as metodologias utilizadas nos ensaios. Apresentam-se, também, os resultados de caracterização dos solos, a localização de sua coleta e o procedimento utilizado na preparação da mistura dos solos. 
O Capítulo 5 apresenta os resultados obtidos neste programa experimental. Apresentam-se os resultados de ensaios de percolação em colunas de solos e ensaios triaxiais do tipo CU (adensado e não drenado).

O Capítulo 6 apresenta a análise dos resultados. Avaliou-se e quantificou-se a influência da solução contaminante na resistência ao cisalhamento dos solos. Apresenta-se, também, uma avaliação da capacidade de atenuação do contaminante pelos solos estudados.

No Capítulo 7 são apresentadas as considerações finais e sugestões para as pesquisas futuras.

No Apêndice A são apresentadas as curvas de chegada, para os três solos estudados, correspondentes aos íons $\mathrm{Cu}^{+2}$ e $\mathrm{Cl}^{-1}$. 
O objetivo deste trabalho é ampliar o estudo que vêm sendo realizado no Departamento de Geotecnia (EESC-USP) em relação à avaliação do comportamento de materiais para utilização como barreiras impermeáveis (liners). Além de analisar o processo de percolação de contaminante, por meio de ensaios de percolação em colunas, pretendeu-se atingir novos alvos, realizando ensaios triaxiais do tipo $\mathrm{CU}$ (consolidado e não drenado) em amostras de solos contaminados. A seguir descrevem-se os objetivos específicos deste trabalho:

- Quantificar a influência da percolação de uma solução de cloreto de cobre aquoso, em três diferentes concentrações, na resistência ao cisalhamento de um solo argiloso (Formação Serra Geral), um arenoso (Formação Botucatu) e uma mistura entre estes solos;

- Avaliar como o processo de contaminação (interação solo-contaminante) pode alterar o comportamento dos solos em termos de condutividade hidráulica e, principalmente, na resistência ao cisalhamento;

- Aprimorar os equipamentos necessários para a realização de ensaios triaxiais (interfaces de pressão), principalmente, em relação ao processo de saturação do corpo de prova por contra pressão utilizando-se a própria solução contaminante. 


\section{REVISÃO BIBLIOGRÁFICA}

\subsection{FONTES DE CONTAMINAÇÃO}

O processo de contaminação dos solos e das águas subterrâneas pode ser provocado por variadas formas e por diferentes fontes contaminadoras. Lundgren (1986) classifica as fontes de contaminação em dois grandes grupos: fontes pontuais e fontes não pontuais. Segundo o autor, a classificação é baseada na escala do mapa utilizado. Em virtude de suas menores dimensões, as fontes pontuais são mais facilmente controladas que as não pontuais.

As principais fontes pontuais de contaminação são:

- Tanques e fossas sépticas;

- Sistemas de coleta e tratamento empregado em manejo de resíduo municipal (resíduos doméstico e industrial);

- Solos nos quais são lançados lodo ou efluentes do sistema de tratamento de esgoto municipal;

- Represamento de resíduos industriais;

- Minas (resíduos de minas);

As principais fontes não pontuais incluem:

- Solos de agricultura e áreas de pasto suburbano (fertilizantes, pesticidas e esterco);

- Solos irrigados de agricultura;

- Áreas urbanas (óleo, gasolina, entre outros);

- Massas de ar (contaminantes transportados pelo ar).

O processo de contaminação dos solos e das águas a partir de uma fonte de contaminação pode ser representado pela Figura 3.1. 


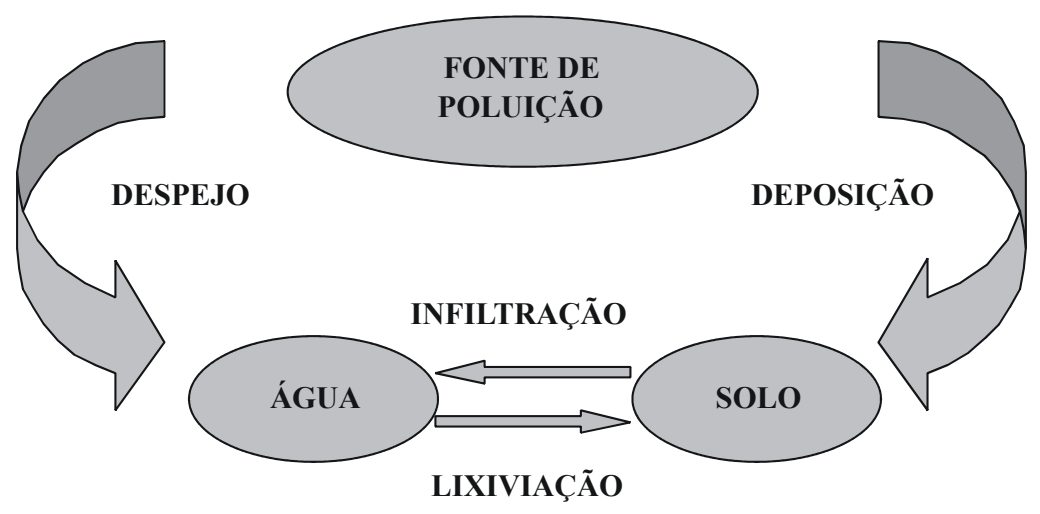

Figura 3.1. Interações existentes entre as fontes poluidoras, o solo e as águas subterrâneas.

A partir da Figura 3.1, observa-se que a fonte de poluição pode ser despejada na água ou depositada no solo, contaminando-os de forma direta. Se medidas preventivas não forem tomadas, estando um deles (água ou solo) contaminado, haverá também a contaminação do outro. Este processo ocorre de forma indireta por meio da infiltração de água no solo ou lixiviação do solo pela água.

\subsection{RESÍDUOS SÓLIDOS}

\subsubsection{Definição e Classificação}

Os resíduos sólidos podem se apresentar sob a forma de sólidos, líquidos, semisólidos ou gases. A norma NBR 10004/87 da Associação Brasileira de Normas Técnicas (ABNT), apresenta a seguinte definição: “Os resíduos nos estados sólidos e semi-sólidos, que resultam de atividade da comunidade, de origem: industrial, doméstica, hospitalar, comercial, agrícola, de serviços de varrição. Ficam incluídas nesta definição os lodos provenientes de sistemas de tratamentos de água, aqueles gerados em equipamentos e instalações de controle de poluição, bem como determinados líquidos cujas peculiaridades tornem inviável o seu lançamento na rede pública de esgotos ou corpos de água, ou exijam para isso soluções técnicas e economicamente inviáveis em face à melhor tecnologia disponivel".

De acordo com Bidoni e Povinelli (1999), os resíduos podem ser classificados em função de sua origem e de sua degradabilidade. Quanto à origem, podem ser classificados em: urbanos, industriais, de serviços de saúde, radioativos e agrícolas. Quanto à degradabilidade, se classificam em: facilmente degradáveis (compostos de matérias orgânicas dos resíduos sólidos urbanos), moderadamente degradáveis (papéis, papelões e material celulósico), 
dificilmente degradáveis (panos, retalhos, borrachas e madeira) e não degradáveis (vidros, metais, plásticos, pedras, terra, entre outros).

Quanto a sua periculosidade, os resíduos sólidos podem ser classificados da seguinte forma (NBR 10004/87):

Tabela 3.1. Classificação dos resíduos sólidos quanto à periculosidade.

\begin{tabular}{cl}
\hline Tipo & \multicolumn{1}{c}{ Características } \\
\hline Classe 1 ( perigoso) & $\begin{array}{l}\text { Apresentam riscos à saúde pública ou ao meio } \\
\text { ambiente. Caracteriza-se por ter uma ou mais das } \\
\text { seguintes propriedades: inflamabilidade, } \\
\text { reatividade, toxidade e patogenicidade }\end{array}$ \\
\hline Classe 2 ( não-inertes) & $\begin{array}{l}\text { Podem ter propriedades como combustibilidade, } \\
\text { biodegrabilidade ou solubilidade, porém não se } \\
\text { enquadram como resíduo 1 ou 3. }\end{array}$ \\
\hline Classe 3 & $\begin{array}{l}\text { Não tem nenhum dos seus constituintes (inertes) } \\
\text { solubilizados em concentrações superiores aos } \\
\text { padrões de potabilidade de águas. }\end{array}$ \\
\hline
\end{tabular}

\subsubsection{Características do Resíduo}

Os resíduos podem conter uma ampla gama de contaminantes inorgânicos, entre eles os metais pesados e os macrocomponentes, que podem ser tanto inertes como perigosos. O termo metais pesados vem sendo amplamente utilizado na literatura científica como elementos com densidade atômicas maiores que $5 \mathrm{~g} / \mathrm{cm}^{3}$. Esse termo engloba grupos de metais, semi-metais e até de não metais (selênio), que normalmente se encontram associados à poluição, à contaminação e à toxicidade. Incluem-se também alguns elementos essenciais aos seres vivos ( $\mathrm{Cu}, \mathrm{Zn}, \mathrm{Mn}, \mathrm{Co}, \mathrm{Mo}$, etc.) e não essenciais ( $\mathrm{Pb}, \mathrm{Cd}, \mathrm{Hg}, \mathrm{As}, \mathrm{Ti}, \mathrm{V}$, etc.). As concentrações desses metais pesados podem variar de 0-100 ppm nos resíduos sólidos domésticos a 100 - 10.000 ppm nos esgotos sanitários e resíduos industriais.

Leite (1995) comenta que os metais pesados mesmo sendo tóxicos são necessários aos microorganismos e à vida. Esta dualidade é uma questão quantitativa, onde o importante é conhecer o limite, no qual, a quantidade de metal pesado passa a ser nocivo ao ser humano. Os máximos valores permitidos, quanto à presença em água potável, comparados aos máximos valores detectados em águas subterrâneas e em águas contaminadas por ação humana, encontram-se na Tabela 3.2: 
Tabela 3.2. Concentrações máximas detectadas em águas subterrâneas natural e contaminadas por ação humana (Água de mina) em mg/L ( MATHESS et al.,1985 - modificado).

\begin{tabular}{cccc}
\hline \multirow{2}{*}{ Metal } & \multirow{2}{*}{$\begin{array}{c}\text { CMP* } \\
\text { (OMS) }\end{array}$} & \multicolumn{2}{c}{ Maiores concentrações detectadas } \\
\cline { 3 - 4 } & 50 & 32.300 & Água natural \\
\hline $\mathrm{As}$ & 10 & 207 & - \\
$\mathrm{Cd}$ & 50 & 400 & 41.100 \\
$\mathrm{Cr}$ & $\mathrm{N} . \mathrm{d}$ & 20 & - \\
$\mathrm{Co}$ & 50 & 344 & - \\
$\mathrm{Cu}$ & 100 & 1.000 .000 & - \\
$\mathrm{Fe}$ & 1 & 0,07 & 45.633 .000 \\
$\mathrm{Hg}$ & 50 & 42.000 & 474.600 \\
$\mathrm{Mn}$ & $\mathrm{Nd}$ & 40.000 & - \\
$\mathrm{Ni}$ & 100 & 1.200 & - \\
$\mathrm{Pb}$ & 100 & 177.000 & 319.300 \\
$\mathrm{Zn}$ & 5000 & & 2.122 .000 \\
\hline
\end{tabular}

*Concentrações máximas permitidas (Organização Mundial de Saúde).

$\mathrm{Nd}=$ não detectadas

Os dados apresentados na Tabela 3.2 mostram a existência de fontes de água contaminadas com concentrações de metais acima do regulamentado pela Organização Mundial da Saúde (OMS). Tais dados retratam a situação de muitas outras fontes que já se encontram impróprias para o consumo. Neste contexto, medidas precisam ser tomadas para controlar essa poluição, minimizando o impacto da chegada de poluentes à zona saturada dos materiais inconsolidados, e mantendo satisfatoriamente a qualidade dos cursos d'água superficiais.

Os íons $\mathrm{Na}^{+}, \mathrm{Ca}^{+2}, \mathrm{~K}^{+}, \mathrm{SO}_{4}^{-2}, \mathrm{Cl}^{-1}, \mathrm{HCO}_{3}$, são chamados de macrocomponentes e correspondem a aproximadamente $90 \%$ dos íons existentes nas águas naturais. Eles estão normalmente presentes em concentrações maiores do que $1 \mathrm{mg} / \mathrm{L}$ em chorumes e ou águas subterrâneas poluídas (FREEZE; CHERRY, 1979). No entanto, como os macrocomponentes não constituem um problema muito severo de poluição para as águas de subsuperfície, os padrões de qualidade normalmente incluem a maior parte destes macrocomponentes na composição da água potável. Além disso, alguns destes macrocomponentes são importantes na atenuação dos metais pesados.

$\mathrm{O}$ cloreto de cobre presente na solução contaminante $\mathrm{CuCl}_{2} \cdot 2 \mathrm{H}_{2} \mathrm{O}$ (cloreto de cobre aquoso) apresenta características químicas que podem ser descritas de forma isolada pelos elementos químicos cloro e cobre. O cloro é um elemento não metálico pertencente ao grupo dos halogênios com raio atômico de 0,099 nm. É um forte agente oxidante que possui muitas aplicações, podendo ser empregado, por exemplo, na cloração da água potável, como descolorante nas indústrias e na produção de uma grande quantidade de produtos químicos. De acordo com resoluções do Conama (1986) para resíduos Classe 1 e 2, a concentração 
máxima permitida é de $250 \mathrm{mg} / \mathrm{L}$. De acordo com Freezy e Cherry (1979), a concentração de cloreto nos líquidos percolados em aterros sanitários varia de 300 a $3000 \mathrm{mg} / \mathrm{L}$.

Já o cobre pode ser classificado como elemento de transição metálico de número atômico 29 e raio atômico de $0,128 \mathrm{~nm}$. É um metal pesado que pode ser altamente tóxico se ingerido, mesmo em pequenas quantidades. A ingestão em quantidades superiores à estabelecida pela Organização Mundial da Saúde (OMS), $50 \mathrm{mg} / \mathrm{L}$, pode desencadear sérios problemas à saúde humana, tais como: irritação da mucosa, problemas hepáticos e renais, câncer, irritação no sistema nervoso e depressão. A contaminação das águas ou dos solos por cobre é provocada mais intensamente por resíduos industriais provenientes de algicidas, fungicidas, industrias de mineração, fundição, galvanoplastia, além do refino e da corrosão de tubos de cobre provocados por águas ácidas.

\subsubsection{Disposição de Resíduos}

Segundo Yong et al. (1992), há pelo menos seis quesitos que devem ser considerados no gerenciamento de disposição de resíduos:

- O resíduo produzido e o contaminante gerado;

- Localização, projeto e conhecimento do substrato geológico;

- Características físicas, químicas e biológicas dos contaminantes percolados através do substrato, interação com o solo, características de transformação e atenuação;

- Previsão do transporte de contaminante;

- Monitoramento e medidas;

- Avaliação das medidas operacionais e de monitoramento, para satisfazer regulamentos e outras normas de segurança.

De acordo com a pesquisa publicada pelo Instituto de Pesquisas Tecnológicas IPT (1995), a disposição final do lixo nos municípios brasileiros é distribuída da seguinte forma:

- $76 \%$ em lixões (a céu aberto);

- $13 \%$ em aterros controlados;

- $10 \%$ em aterros sanitários;

- $0,9 \%$ em usinas de compostagem;

- $0,1 \%$ em usinas de incineração. 
Nos países desenvolvidos, a realidade apresenta-se bem diferente da brasileira. De acordo com dados apresentados por Balerini (2000), a disposição final em tais países é distribuída da seguinte maneira:

- $55 \%$ em aterros sanitários;

- $25 \%$ em usinas de incineração;

- $15 \%$ em usinas de reciclagem;

- $5 \%$ em usinas de compostagem.

Ao analisar os processos utilizados para a destinação dos resíduos, salienta-se que a reciclagem e a compostagem não são técnicas de disposição final, mas sim artifícios para a redução do volume de resíduo através de sua reutilização na forma de produtos secundários. Estas duas soluções não podem ser aplicadas em larga escala no Brasil porque são de custo elevado e de baixa produção. Enquanto a compostagem esbarra na dificuldade de se obter um produto de qualidade e de boa aceitação pelos agricultores, a reciclagem é adotada como instrumento de educação ambiental, que geralmente necessita de subsídios. O alto custo da incineração também inviabiliza esta prática no Brasil. Entretanto, como dispomos de grandes áreas de terra, a tendência é o crescimento de investimentos na construção de aterros sanitários, assim como ocorre nos países desenvolvidos.

\subsection{ATERRO SANITÁRIO}

\subsubsection{Definição e Características Gerais}

Segundo a norma NBR 8419/92 da Associação Brasileira de Normas Técnicas (ABNT): "Aterro sanitário de resíduos sólidos urbanos consiste na técnica de disposição de resíduos sólidos urbanos no solo, sem causar danos ou riscos à saúde pública e à segurança, minimizando os impactos ambientais, método este que utiliza princípios da engenharia para confinar os resíduos à menor área permissível, cobrindo-os com uma camada de terra na conclusão de cada jornada de trabalho ou intervalos menores se necessário”.

Um aterro sanitário é composto por diversas partes, dentre as quais pode-se destacar: 
- Revestimento lateral e de fundo: visa impedir a contaminação dos solos e lençol freático, cujo comportamento mecânico em termos de resistência ao cisalhamento é objeto de estudo deste trabalho;

- Células de resíduo: consiste no volume de resíduos disposto durante um período de lançamento, incluindo o material de recobrimento que o envolve;

- Recobrimento da célula: camada de material inerte (solo ou outro material) que cobre a superfície da célula. Sua função é impedir o espalhamento dos resíduos de forma a minimizar impactos ao meio ambiente, tais como: eliminação de proliferação de vetores, redução de exalação de odores e formação de poeiras a partir dos resíduos. Além das características mencionadas, o recobrimento permite o tráfego de veículos coletores sobre o aterro.

- Bermas: realizadas em aterros com altura superior a 15 metros para garantir a estabilidade do talude lateral do aterro sanitário. São construídas entre todas as camadas de resíduos;

- Sistema de drenagem de águas pluviais e líquidos percolados: os drenos de águas pluviais são dispositivos projetados para captar e conduzir as águas superficiais para áreas externas do aterro, prevenindo-o contra a erosão. Os líquidos percolados (chorume) são coletados através de drenos internos e conduzidos a um tanque de armazenagem, onde se realiza o tratamento do líquido percolado;

- Sistema de drenagem de gases: os gases gerados no processo de decomposição da matéria orgânica podem resultar em sérios problemas, pois o gás metano em alta concentração pode ser explosivo. Esses gases devem ser drenados para evitar que sua migração, através dos poros do subsolo, atinja redes de esgoto, fossas, poços e edificações.

A Figura 3.2 ilustra esquematicamente um aterro sanitário, mostrando as três fases de seu ciclo e os elementos que o constituem. 


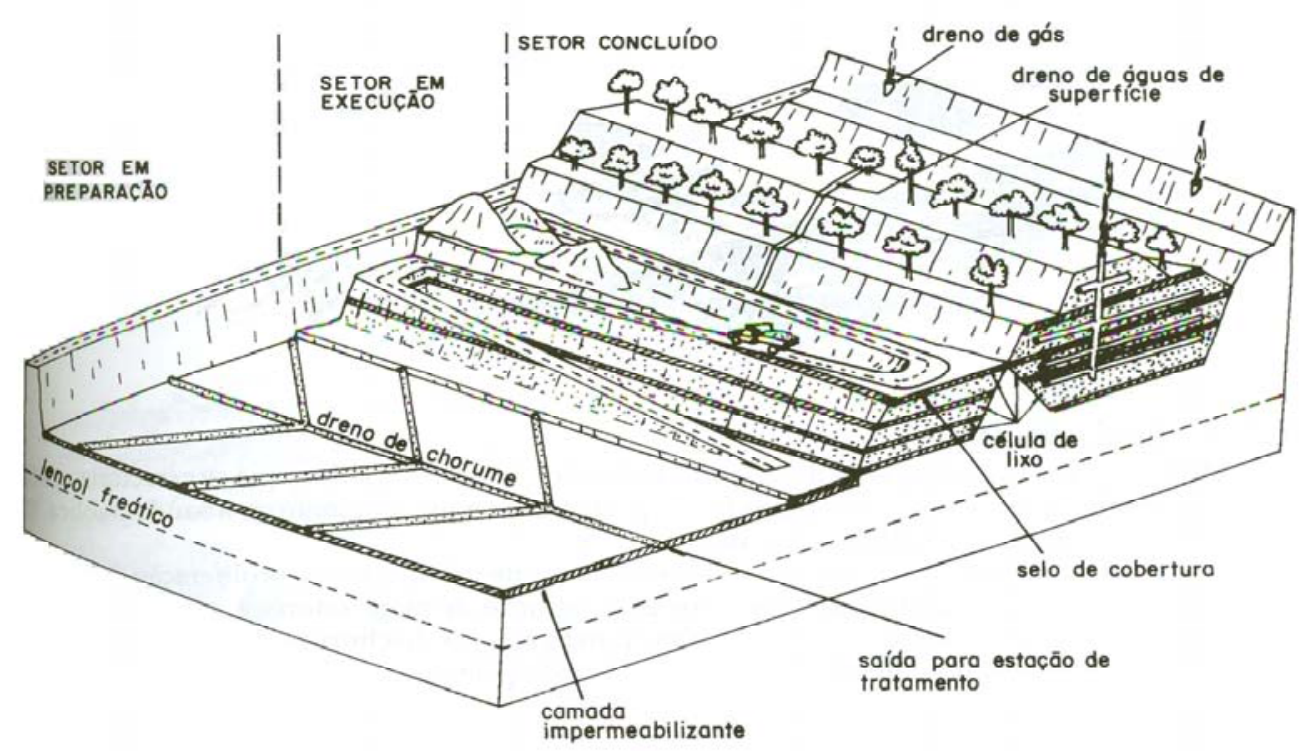

Figura 3.2. Elementos constituintes do aterro sanitário (Instituto de Pesquisas Tecnológicas - IPT, 1995).

\subsubsection{Métodos Construtivos dos Aterros Sanitários}

A construção de aterros sanitários envolve movimentação de terra e engloba vários fatores. As formas construtivas e operacionais dependem da topografia do local onde será implantado o aterro. Aterros realizados em regiões planas (aterros de superfície) podem ser operados pelos seguintes métodos: método das trincheiras, método da escavação progressiva e método da área. Em contrapartida, os aterros executados em regiões de topografia acidentadas podem ser construídos tanto em lagoas, como em depressões. Os principais métodos construtivos e operacionais dos aterros sanitários são apresentados a seguir (LEITE, 1991):

- Método das trincheiras: escavação de trincheiras com larguras de 6,0 a 40,0 m e profundidade de 3,0 a 4,0 m. O resíduo é lançado, compactado e o material escavado é utilizado na cobertura.

- Método da escavação progressiva: executado acima do nível natural do terreno. Deposita-se o resíduo sobre o solo, compactando-o em camadas de 3,0 a 4,0 m. Lança-se um material de cobertura para formar as células sanitárias.

- Método da área: aterros em áreas baixas e úmidas, sujeitas à flutuação da maré. Requer cuidados especiais durante sua execução, como: rebaixamento do lençol freático, construção de diques. Entretanto, este método permite a recuperação de áreas inaproveitáveis. 
- Aterros em lagoas: executados em lagoas, resultantes de escavações para a extração de areia ou argila. O lodo depositado no fundo da lagoa é dragado e utilizam-se os materiais existentes nas margens da lagoa para a cobertura do aterro.

- Aterros em depressões: a construção dos aterros é realizada em fundos de vales. Os materiais localizados nas encostas adjacentes podem ser utilizados na cobertura.

\subsubsection{Utilização de Aterros Sanitários}

A utilização de aterros sanitários, para disposição das mais variadas formas de resíduos, apresenta vantagens e desvantagens. Suas vantagens são: aceitar qualquer tipo de resíduos sólidos; utilizar na sua execução e operação equipamentos utilizados em serviços de terraplenagem; utilizar áreas com topografia acidentadas; controlar a proliferação de vetores, tais como ratos e artrópodes e possibilitar a disposição do lodo. Quanto às desvantagens: transporte à longa distância; produção de águas residuais; disponibilidade limitada de material de cobertura; possibilidade de poluição do lençol freático; e produção de ruídos e poeiras durante a execução do aterro (SCHALCH et al.1990).

O processo de decomposição predominantemente anaeróbia em aterros sanitários produz o chorume (líquido negro, ácido e malcheiroso). A quantidade produzida depende do teor de umidade encerrado na matéria orgânica, mas é normalmente reduzida. O maior problema reside nas águas pluviais não desviadas do aterro, que se infiltram, arrastando o chorume e outros elementos prejudiciais tanto para o lençol subterrâneo como para as águas superficiais próximas ao aterro (BIDONI; POVINELLI, 1999).

Neste sentido, a operação do aterro sanitário deve ser efetuada de modo a garantir que as especificações e cuidados estipulados pelo projeto se mantenham durante toda a sua vida útil, minimizando os riscos de acidentes ambientais. Deve-se manter um sistema de monitoramento dos recursos hídricos para se detectar eventuais falhas na impermeabilização. Isso pode ser realizado por um programa de amostragem periódica nos mananciais da região.

\subsection{BARREIRAS SELANTES}

As barreiras selantes, também denominadas de liners, são recursos utilizados para minimizar o movimento de fluidos contaminados (chorume, rejeitos líquidos, hidrocarbonetos e outros). Assim, protege-se o ambiente circundante ao aterro contra a poluição, garantindo a 
potabilidade das águas naturais. Os liners podem ser constituídos de materiais naturais (solos argilosos, argilas compactadas e misturas compactadas), artificiais (geossintéticos em geral), ou a combinação de ambos (GCL's).

O liner vem sendo utilizado nas mais variadas obras de engenharia, tais como aterros sanitários e industriais, canais de reservatórios, diques, etc. Nos aterros sanitários, por exemplo, podem ser empregados na base, em coberturas superficiais protetoras e na forma de barreiras, representadas preferencialmente por paredes de contenção utilizadas para controlar a migração lateral dos fluidos. Estas barreiras, como característica principal, devem apresentar estanqueidade, durabilidade, resistência mecânica, resistência a intempéries e principalmente compatibilidade com os resíduos a serem enterrados.

Segundo Leite e Zuquette (1995), a escolha de um determinado tipo de liner é influenciada pelos seguintes fatores:

- Uso a que se destina;

- Ambiente físico;

- Composição química da solução percoladora e da água subterrânea;

- Vida útil do projeto;

- Taxa de infiltração;

- Restrições físicas.

As barreiras argilosas podem ser classificadas em três tipos:

- Argilosas naturais: barreiras formadas por terreno natural já existente nos locais de implantação do aterro sanitário. Devem possuir elevado teor de argila (partículas finas), para conferir aos solos baixa permeabilidade e grande capacidade de adsorção, principalmente provocadas pela presença de cargas eletrostáticas na sua superfície (FARINHA, 1998).

- Argilosas compactadas: são constituídas por material argiloso compactado. A condutividade hidráulica depende da estrutura do material inconsolidado, o que inclui: distribuição granulométrica, tamanho dos poros, orientação das partículas, agregados, forças de ligação e agentes cimentantes. A distribuição dos tamanhos dos grãos e dos agregados de argila é função da sua mineralogia, da composição química do fluido dos poros e do teor de umidade de compactação. (LEITE; ZUQUETTE, 1995). 
- Geossintéticos argilosos (GCL's): os geocompostos bentoníticos (GCL's) consistem num produto manufaturado à base de bentonita natural, geralmente sódica ou cálcica, a qual exibe elevado potencial de expansão. Pode ser aderida quimicamente ou mecanicamente a elementos geossintéticos, formando um sistema de baixa condutividade hidráulica.

As possíveis configurações de liners são apresentadas por Sharma e Lewis (1994), nas Figuras 3.3 (a) e 3.3 (b).
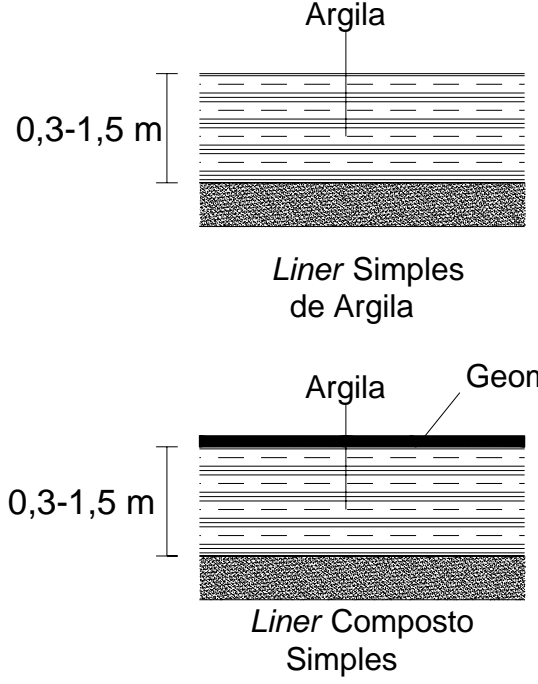

Geomembrana

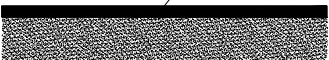

Liner Simples de Geomembrana

Geomembrana Liner Geocomposto Bentonítico

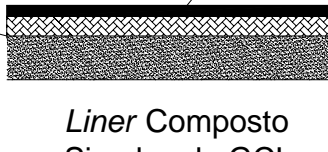

Figura 3.3 (a). Configurações de liners (SHARMA; LEWIS, 1994).

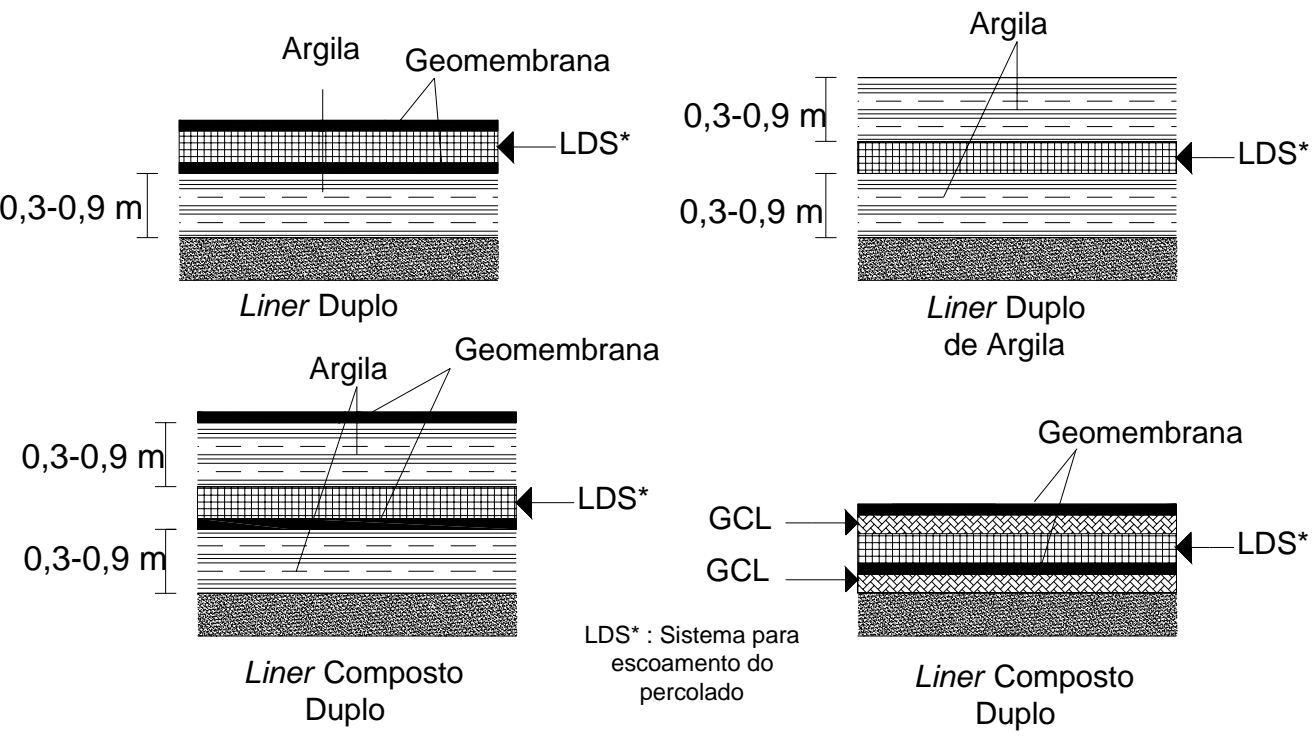

Figura 3.3 (b). Configurações de liners (SHARMA; LEWIS, 1994). 
Segundo estes mesmos autores, os liners duplos ou os liners compostos duplos podem ser utilizados para aumentar o fator de segurança do sistema de impermeabilização. $\mathrm{O}$ mecanismo de percolação e contenção de líquidos contaminados é geralmente o mesmo, tanto para o primeiro quanto para o segundo liner. Entretanto, se o primeiro apresentar um comportamento satisfatório, a percolação sobre o segundo será minimizada, garantindo assim, uma melhor eficiência do sistema.

Em relação aos liners compactados, foco principal deste trabalho, Brandl (1992) lista algumas características que este sistema de contenção deve apresentar:

- Minimizar a migração de poluentes através de advecção e/ou difusão;

- Alta capacidade de adsorção e retardamento de poluentes;

- Resistência química;

- Resistência à erosão;

- Apresentar flexibilidade (não ser sensível a recalques diferenciais);

- Baixa capacidade de expansão e retração.

Segundo Rowe et al. (1995), existem algumas exigências requeridas para atender à legislação, no tocante à utilização de barreiras argilosas:

- O liner deve condutividade hidráulica $(k)$, de pelo menos $10^{-9} \mathrm{~m} / \mathrm{s}$ e estar isento de fraturas naturais ou induzidas pela compactação. Do ponto de vista do fluxo químico, $10^{-10} \mathrm{~m} / \mathrm{s}$ é a condutividade hidráulica ideal, sendo a difusão molecular o mecanismo de transporte dominante;

- A baixa condutividade hidráulica está normalmente associada à presença de argilominerais. Assim, pelo menos de 15 a $20 \%$ do solo deve ser constituído por partículas menores que $2 \mu \mathrm{m}$, deve apresentar índice de plasticidade maior que $7 \%$ e atividade coloidal maior que 0,3. Alternativamente, a mínima capacidade de troca catiônica deve ser de 10 meq /100 g de solo;

- A barreira argilosa deve ser compatível com os contaminantes que irá reter. Em outras palavras, a condutividade hidráulica $(k)$, não deve sofrer aumentos significativos com a pecolação do contaminante;

- A espessura mínima do liner argiloso compactado, utilizado em aterros sanitários de resíduos domésticos, geralmente situa-se entre 0,9 a 1,0 m. Em alguns casos, dependendo da legislação local, esta espessura pode ser reduzida para 0,6 m, quando for utilizado liner composto; 
- Para a impermeabilização e contenção de resíduos industriais e tóxicos, a espessura mínima de uma barreira argilosa é de 3,0 a 4,0 m, embora algumas legislações prefiram adotar espessuras acima de $15,0 \mathrm{~m}$ ou sistemas de liners múltiplos.

Segundo Benson e Daniel (1994), as trajetórias de fluxo em solos compactados são sensíveis aos métodos utilizados durante a preparação e compactação dos solos. O fluxo não se comporta de uma maneira contínua, ou seja, se move através de espaçados macro poros, que se apresentam em pequena porcentagem em relação ao volume total do solo. $\mathrm{O}$ fluido inicia sua percolação através das camadas por meio dos poros. Ao encontrar as interfaces horizontais entre duas camadas, continua sua propagação até migrar em um outro poro existente na camada subjacente. Esta habilidade do fluido escoar entre as camadas tem efeito significante na performance dos liners, sendo um indício que o solo foi processado impropriamente e que a compactação foi realizada de forma satisfatória.

Daniel (1993) comenta que os liners argilosos compactados são constituídos, principalmente por solos naturais, podendo em alguns casos, conter materiais processados, como a bentonita ou materiais sintéticos como polímeros. Os taludes laterais são compactados em camadas que podem estar dispostas horizontalmente ou paralelamente a eles, conforme apresentado nas Figuras 3.4 (a) e 3.4 (b). Entretanto, a disposição em camadas paralelas ao talude não é recomendada para taludes com inclinação maiores que 2,5-3,0: 1,0 (Horizontal: Vertical). A preferência deve ser para a utilização de liners laterais compactados em camadas horizontais, já que os efeitos de uma área construída com material impróprio ou de uma ligação imperfeita entre as camadas proporcionam menor instabilidade. Ao realizar a compactação em camadas horizontais, deve-se promover uma pequena inclinação da camada para minimizar o fluxo ao longo das interfaces. 
(a)

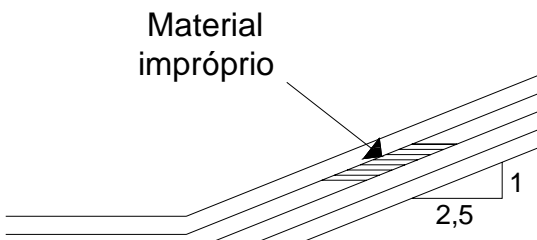

(b) Material

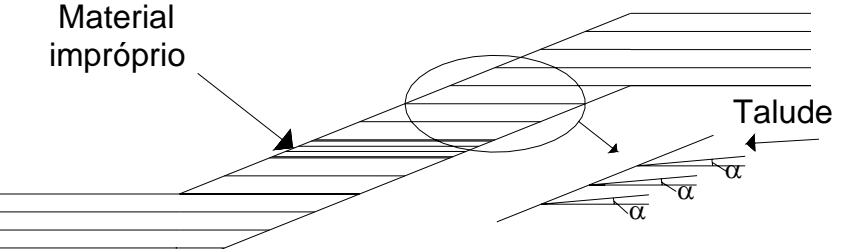

Figura 3.4. Talude lateral de liners construído em camadas paralelas (a) e horizontais (b) (DANIEL, 1993).

O mesmo autor ainda comenta que o objetivo da compactação de um solo para utilização como liner é remover os seus torrões, tornando-o uma massa homogênea e livre de grandes e contínuos vazios interconectados. Ao realizar a compactação de forma adequada, esperam-se obter baixos valores de condutividades hidráulicas (menores que $10^{-9} \mathrm{~m} / \mathrm{s}$ ). As camadas compactadas devem estar perfeitamente aderidas, para eliminar os possíveis caminhos preferenciais existentes entre as camadas.

Outra forma para se reduzir a condutividade hidráulica de um liner, é realizar a compactação do solo com teor de umidade acima do valor ótimo, podendo, para alguns solos, o desvio de umidade ser de até $2 \%$. A compactação no ramo úmido possibilita que as partículas fiquem arranjadas de forma dispersa, facilitando o processo de compactação. Em contrapartida, ao se compactar o solo com teor de umidade abaixo do ótimo, pode ocorrer o processo de agregação das partículas. Tal fato proporciona o aumento do volume de vazios do solo, aumentando a condutividade hidráulica do solo e prejudicando o desempenho da barreira impermeável.

\subsection{SOLOS LATERÍTICOS NA COMPOSIÇÃO DE LINERS}

A utilização de materiais encontrados em áreas próximas aos locais de implantação das obras é de extrema importância, pois elimina o custo originado pelo seu transporte. Neste sentido, a utilização de solos lateríticos é uma alternativa interessante, já que de acordo com Melfi (1994), o Brasil apresenta mais de 60\% de sua superfície recoberta por diferentes solos lateríticos. A Figura 3.5 apresenta a distribuição destes solos no território brasileiro. 


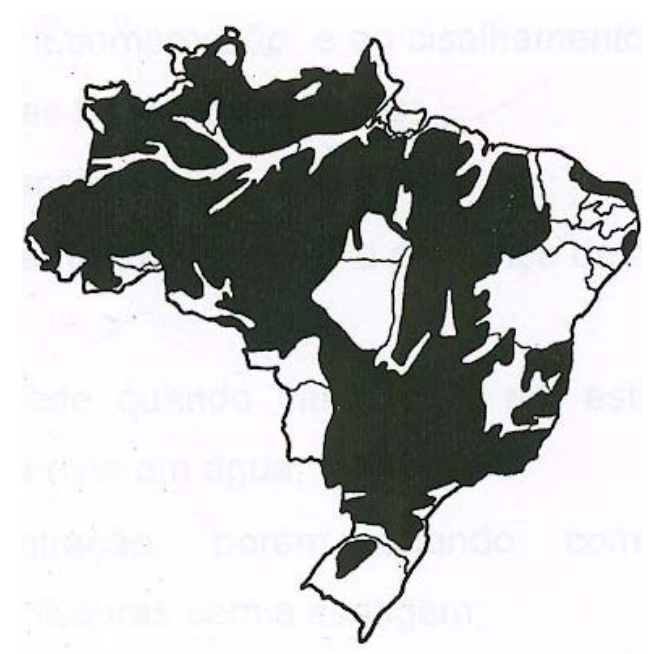

Figura 3.5. Distribuição dos solos lateríticos no Brasil (MELFI, 1994).

O solo laterítico é uma variedade de solo superficial típico da evolução de solos de clima quente com um regime de chuvas de moderadas a intensas (regiões tropicais). Este tipo de solo apresenta-se, geralmente, com uma granulometria fina e com microagregação, sendo costumeiramente classificado na pedologia como latossolo. A fração argila dos solos lateríticos caracteriza-se por conter elevada concentração de ferro e alumínio na forma de óxidos e hidróxidos. Usualmente, estes sais se encontram recobrindo agregações de partículas argilosas. O argilomineral geralmente presente na fração argila dos solos lateríticos é a caulinita, que pertence à família dos argilominerais menos ativos.

Leite (1995) comenta que a maior quantidade de óxidos e hidróxidos na composição destes solos pode resultar no aparecimento de cargas variáveis (positivas e negativas), que dependem principalmente das condições de $\mathrm{pH}$ do meio circundante. Por outro lado, em solos formados em clima frio e temperado, predominam argilominerais com cargas permanentes e negativas, tais como esmectitas, cloritas e ilitas. As diferenças composicionais citadas influenciam significativamente nos processos de retenção de contaminantes, e, portanto, devem ser consideradas nas avaliações desses materiais para utilização como liners.

Os dados geológicos e pedológicos, segundo Nogami e Villibor (1995), consideram a origem, a constituição e a evolução dos solos, relegando para um plano secundário suas propriedades, sobretudo mecânicas e hidrológicas, de interesse fundamental para seu uso em obras civis. Desta forma, a utilização dos solos lateríticos, para tal finalidade, está intimamente ligada ao uso apropriado de um método de estudo geotécnico, atualmente 
designado MCT (Miniatura, Compactado, Tropical). A consideração desse método é indispensável para classificação e identificação dos solos lateríticos.

Ainda segundo Nogami e Villibor (1995), os solos lateríticos apresentam características geotécnicas que interferem no projeto executivo de uma barreira impermeável:

- Os óxidos de ferro e os hidróxidos de alumínio possuem elevada superfície especifica, baixa plasticidade, não apresentam potencial de expansão e nas condições naturais de $\mathrm{pH}$, apresentam capacidade de troca catiônica desprezível para solos com predomínio de cargas positivas;

- Apresentam resistência à compressão e ao cisalhamento acima do previsto pelos índices físicos;

- Quando inundados e carregados apresentam comportamento colapsível;

- Quando compactados podem apresentar fissuras;

- Na fração areia, há predominância dos agregados (peds), sendo necessário interpretar de forma cuidadosa as curvas granulométricas obtidas pelos métodos tradicionais.

Os materiais inconsolidados, utilizados na presente pesquisa, são tipicamente lateríticos, sendo resultantes do intemperismo de rochas das Formações Serra Geral e Botucatu. As propriedades físico-químicas destes solos serão apresentadas de forma mais detalhada no Capítulo 4.

\subsection{MECANISMOS FÍSICOS DE TRANSPORTE DE CONTAMINANTES}

Para o entendimento e conseqüente tratamento de qualquer problema de contaminação no solo, é necessário verificar dois casos gerais. O primeiro se refere aos contaminantes bastante miscíveis em água, tais como os compostos inorgânicos (ácidos, bases e sais) e os orgânicos hidrofilicos (ácidos e bases orgânicos e compostos neutros). O segundo caso se refere aos contaminantes pouco miscíveis ou imiscíveis em água, que se incluem os compostos orgânicos hidrofóbicos.

A presente pesquisa está restrita a contaminantes inorgânicos. As soluções contaminantes inorgânicas são constituídas pelo soluto (substâncias sólidas, moléculas e íons) e pelo solvente (água). O transporte desta solução pode ser descrito como sendo um processo, em que o fluxo através do solo provoca o processo de transferência dos solutos da solução contaminante para o solo, segundo um mecanismo físico-químico. 
Os principais processos físicos responsáveis pelo transporte de contaminantes são a advecção e a dispersão hidrodinâmica (dispersão mecânica e difusão molecular).

\subsubsection{Advecção}

No transporte por advecção, os solutos são transportados concomitantemente com a corrente fluida ou solvente, tipicamente água, em resposta a um gradiente hidráulico (SCHACKELFORD, 1993). A concentração da solução permanece constante durante o processo e o movimento do contaminante pode ser analisado como um fluxo de água em meio poroso, ou seja, através da velocidade de percolação nos vazios do solo, dada pela equação:

$$
v_{s}=\frac{v}{n}
$$

onde:

$v_{s}=$ velocidade de percolação;

$v=$ velocidade de Darcy;

$n=$ porosidade do solo.

O processo de advecção segue a lei de Darcy e está diretamente relacionado com a condutividade hidráulica $(k)$. Sendo assim, o escoamento unidimensional do contaminante, pode ser descrito por:

$$
v=k i=-k \frac{\partial h}{\partial x}=\frac{Q}{A}
$$

onde:

$k=$ condutividade hidráulica;

$i=$ gradiente hidráulico;

$h=$ diferença de carga entre as duas faces livres do solo;

$x=$ direção do fluxo;

$Q=$ taxa de fluxo volumétrico (vazão);

$A=$ área da secção transversal total do solo (sólidos mais vazios) ortogonal à direção de fluxo. 
Assim, os fatores que interferem na condutividade hidráulica também interferem no transporte por advecção. Bueno e Vilar (1997) mencionam que tais fatores estão relacionados às características do fluido e ao tipo de solo:

- Relacionados ao fluido: peso específico e viscosidade;

- Relacionados ao solo: tamanho das partículas, índice de vazios, grau de saturação e estrutura do solo.

O fluxo de soluto através do processo de advecção é definido por:

$$
J_{a}=v C_{s}=k i C_{s}=v_{s} n C_{s}
$$

onde:

$J_{a}=$ fluxo de soluto por advecção (unidade de área por tempo);

$C_{s}=$ concentração do soluto.

A Figura 3.6 mostra o transporte do soluto por advecção, considerando-se uma condição ideal de fluxo macroscópico unidimensional. Percebe-se que a frente de contaminação acompanha o fluxo da solução e que, após um intervalo de tempo $\left(t_{1}\right)$, e percorrida uma distância $d$, a concentração do soluto permanece constante no meio poroso, ou seja, o soluto não é reativo com o solo.

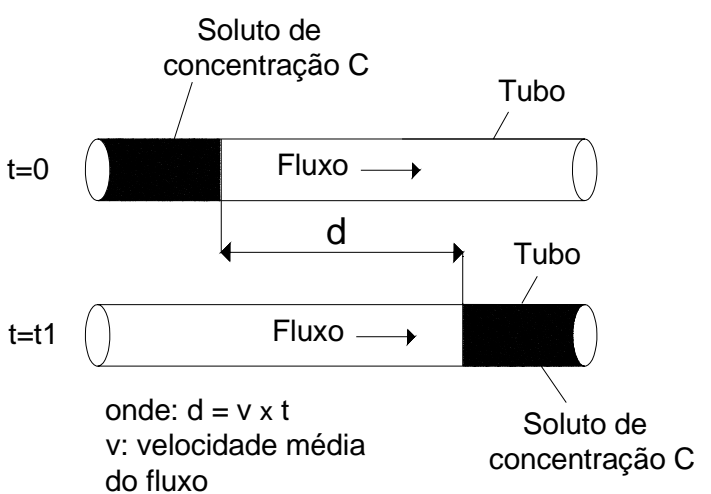

Figura 3.6. Representação do transporte de contaminante por advecção (SHARMA; LEWIS, 1994).

\subsubsection{Dispersão Hidrodinâmica}

O fenômeno de dispersão hidrodinâmica, de acordo com Sharma e Lewis (1994), consiste no espalhamento do soluto para fora da trajetória de fluxo. Durante este fenômeno, o soluto não se movimenta concentrado, mas sim disperso, resultando na diluição da solução, 
conforme apresenta a Figura 3.7. As componentes resultantes desta diluição são denominadas de dispersão mecânica e difusão molecular.

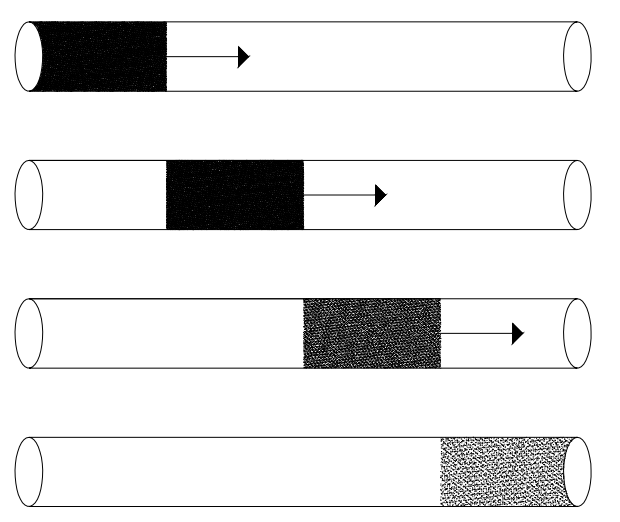

Figura 3.7. Representação do transporte de contaminante por dispersão hidrodinâmica ( SHARMA; LEWIS, 1994).

- Dispersão Mecânica

A dispersão mecânica é definida por Schackelford (1993) como o processo de espalhamento do soluto provocado por uma variação na velocidade de percolação $\left(v_{s}\right)$, durante o transporte de contaminantes através dos poros dos materiais. A nível microscópico, essas variações estão relacionadas a três diferentes fatores, ilustrados na Figura 3.8 e descritos na seqüência:

(a)

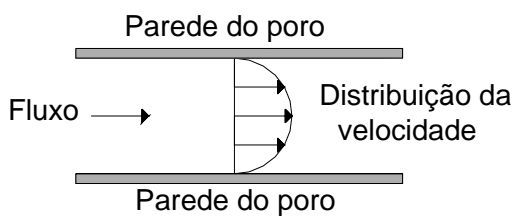

(b)

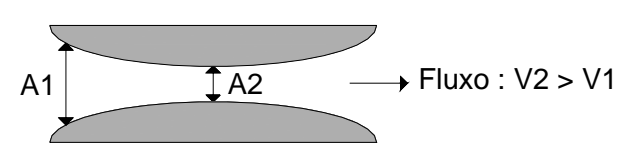

(c)

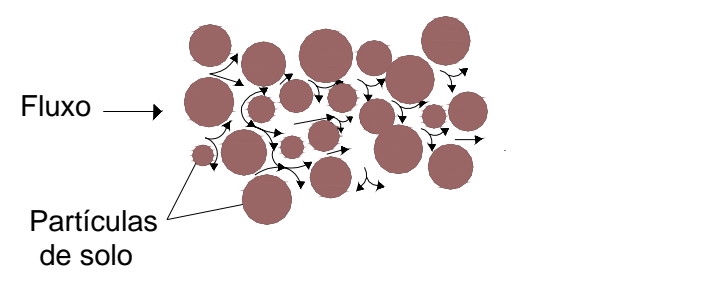

Figura 3.8. Fatores que interferem no transporte por dispersão mecânica no solo.(SCHALCKELFORD, 1993 - modificado). 
(a) A velocidade de fluxo através de um canal poroso do solo apresenta-se distribuída com maior intensidade no centro do canal, pois as laterais sofrem o efeito de atrito nas paredes;

(b) De acordo com a equação da continuidade, a diferença nos tamanhos dos canais dos poros provoca alteração nas velocidades, ou seja, para pequenas aberturas de poros, a velocidade do fluxo tende a aumentar;

(c) Variação de velocidade devido à tortuosidade na matriz do solo, causada pelas ramificações dos canais de fluxo.

Segundo Schackelford (1993), o fluxo de soluto por dispersão mecânica ocorre da seguinte forma:

$$
J_{m}=-D_{m} n \frac{\partial C}{\partial x}
$$

onde:

$D_{m}=$ coeficiente de dispersão mecânica $\left[\mathrm{L}^{2} \mathrm{~T}^{-1}\right]$.

$n=$ porosidade do solo;

$\mathrm{C}=$ concentração;

$x=$ direção do fluxo.

O coeficiente de dispersão mecânica pode ser definido por:

$$
D_{m}=\alpha \times v_{s}
$$

onde:

$\alpha=$ dispersividade no meio, podendo tanto ser longitudinal quanto transversal, apresentando dimensões de comprimento (L);

$v_{s}=$ velocidade de percolação média.

\section{- Difusão Molecular}

De acordo com Bedient et al. (1994), difusão molecular é um processo de transporte de contaminante, no qual o soluto percola através do solo em resposta a um gradiente de concentração, ou seja, de uma região de maior para menor concentração. $O$ mecanismo da difusão molecular tem significância em solos de baixa permeabilidade (por 
exemplo, liners argilosos), ou ainda quando o transporte se processa durante longos períodos de tempo.

Segundo Schackelford (1993), o fluxo do soluto por este processo é assumido como sendo diretamente proporcional ao gradiente de concentração, conforme a teoria da difusão molecular, descrita pela primeira lei de Fick:

$$
J_{D}=-D_{0} \frac{\partial C}{\partial x}
$$

onde:

$J_{D}=$ fluxo de soluto por unidade de tempo e por unidade de área;

$D_{0}=$ constante de proporcionalidade denominada de coeficiente de difusão

molecular.

O sinal negativo na Equação (6) indica que o fluxo por difusão ocorre no sentido do decréscimo de concentração.

Para o caso específico de difusão em meios porosos (solos) saturados, a primeira lei de Fick é apresentada de forma modificada:

$$
J_{D}=-D^{*} n \frac{\partial C}{\partial x}
$$

onde:

$D^{*}=$ coeficiente de difusão molecular efetiva.

Quando o fluxo caminha através de caminhos tortuosos do solo, o coeficiente de difusão efetiva $\left(D^{*}\right)$ se apresenta reduzido em relação ao coeficiente de difusão $\left(D_{o}\right)$. Esta redução é provocada pelo aumento da trajetória do soluto.

Em um solo, especialmente aqueles com granulometria fina, a difusão é consideravelmente menor do que em uma solução livre. Isso se deve à tortuosidade das trajetórias de fluxo e à retenção de íons e moléculas nas superfícies das suas partículas (MITCHELL, 1991).

\subsubsection{Mecanismo Final de Transporte de Contaminantes}

A partir da descrição dos processos de transporte de contaminantes em materiais porosos, é possível concluir que, em geral, o fluxo total unidimensional de massa $\left(J_{T}\right)$ é 
definido pela somatória dos fluxos de advecção $\left(J_{A}\right)$ e da dispersão hidrodinâmica $\left(J_{D}+J_{M}\right)$, como apresentado pela equação 8 (SCHACKELFORD, 1993):

$$
J_{T}=J_{A}+J_{D}+J_{M}
$$

Os três processos são ativos durante o transporte, mas o efeito da dispersão mecânica apresenta-se com menor importância quando as velocidades de percolação são baixas. Assim, em barreiras selantes, este tipo de transporte pode ser negligenciado e o transporte de contaminante pode ser verificado por modelos advectivos e difusivos.

\subsection{INTERAÇÃO ENTRE O SOLO E A SOLUÇÃO CONTAMINANTE}

Solutos reativos são aqueles que apresentam diversos tipos de reações com a fase sólida do solo e, por isto, têm seus movimentos atenuados. A segurança e a durabilidade do liner estão relacionadas à capacidade de atenuação do contaminante pelo solo, daí a necessidade de compreender como ocorre o processo de interação entre o solo e o contaminante.

O sistema solo é composto por três fases: sólida, líquida e gasosa. A fase sólida pode ser constituída por diversos tipos de materiais, dentre os quais, minerais de argila e/ou quartzo, feldspato, mica, óxidos e hidróxidos de Fe, Al, Mn, agentes cimentantes e matéria orgânica. Os vazios do solo podem ser constituídos por uma fase líquida (ácidos e água) e por gases.

Segundo Krauskopf (1972), a fase sólida, quando composta por partículas muito finas e dispersas em outra substância, são consideradas como colóides. Os colóides apresentam uma aparente homogeneidade e estabilidade quando em suspensão e suas partículas são eletricamente carregadas, provocando uma grande dispersão das partículas quando em contato com água.

De acordo com Mitchell (1993), as argilas são consideradas colóides do tipo liofóbica ou hidrofóbica, isto é, devido à presença de fortes ligações entre os átomos de sílicio e de oxigênio nos cristais dos argilominerais, não atraem água ou outras substâncias líquidas para junto de sua superfície. Esta designação surgiu da necessidade em se distinguir as argilas de outras substâncias coloidais que apresentam elevada afinidade por água. 


\subsubsection{Influência das Cargas Elétricas no Comportamento do Solo}

O processo de atenuação dos contaminantes pelos solos, mais especificamente, pela fração fina dos solos, envolve fatores químicos e físico-químicos. Na interface sólidolíquida, as interações são provocadas basicamente pelo desequilíbrio de cargas das partículas. Tal processo é responsável pela maioria das regras sobre o comportamento da fração fina do solo, em relação ao arranjo da estrutura, resistência ao cisalhamento, condutividade hidráulica, volume de vazios, entre outros.

De acordo com Sparks (1986), as possíveis fontes de cargas nas partículas coloidais do solo são substituição isomórfica, dissolução iônica e ionização de grupos orgânicos. Estas fontes serão apresentadas a seguir.

- Substituição isomórfica: é a fonte de cargas mais comum na superfície coloidal do solo. É proveniente de imperfeições estruturais existentes no interior da estrutura cristalina, promovendo assim, substituição de íons ou fixação em sítios vagos que resultam freqüentemente em cargas permanentes, podendo ser assumida tanto como positiva, quanto negativa. Entretanto, devido às limitações no tamanho do íon, geralmente ocorre a substituição de um elemento de maior valência, por outro de menor valência. A título de exemplo, $\mathrm{Al}^{+3}$, ao substituir $\mathrm{Si}^{+4}$, provoca deficiências de cargas positivas no cristal, fato que resulta em cargas negativas na estrutura da argila;

- Dissolução iônica: as cargas superficiais são desenvolvidas através da dissolução iônica da água. Os íons $H^{+}$e $O H$, ao serem adsorvidos pela superfície argilosa, formam superfícies hidroxiladas podendo assumir cargas positivas ou negativas. O sinal e a magnitude das cargas são determinados pelo excesso de íons $\left(\mathrm{H}^{+}\right.$e $\left.\mathrm{OH}\right)$ existentes na superfície. Solos compostos por óxidos e/ou hidróxidos são mais susceptíveis a este processo, desenvolvendo assim, cargas variáveis;

- Ionização: está normalmente associada à fração orgânica do solo. O colóide adquire cargas através da dissociação dos íons $H^{+}$, presentes na atividade do grupo funcional (carboxil, fenol e grupos amínicos), podendo gerar cargas positivas ou negativas.

Independentemente da origem da carga na superfície coloidal, uma quantidade de cargas opostas deve ser acumulada na fase líquida do solo. Busca-se a neutralidade elétrica, 
ou seja, para superfícies coloidais carregadas negativamente, cátions devem ser atraídos junto de sua superfície por um processo de adsorção de íons por meio de forças eletrostáticas (SPARKS, 1986).

Os íons que se situam junto á superfície do argilomineral e formam a primeira camada de cátions atraída às cargas negativas superficiais, consistem na dupla camada elétrica. A grande concentração de íons de cargas opostas junto à superfície gera um gradiente de concentração e algumas dessas cargas são transportadas por processos difusivos para distâncias mais afastadas da superfície. A esta camada dá-se o nome de dupla camada difusa.

A Figura 3.9 (a) exemplifica a formação da dupla camada elétrica e dupla camada difusa. A união entre estas duas camadas dá-se o nome de dupla camada iônica. A Figura 3.9 (b) apresenta o efeito entre a concentração e a distância das cargas à superfície carregada negativamente. Na medida em que se afasta da superfície a concentração de cátions tende a diminuir, mas, em contrapartida, a concentração de ânions tende a aumentar, tendendo ao equilíbrio em uma certa distância.

A espessura da dupla camada elétrica é variável e afeta significativamente o comportamento mecânico do solo. Esta variação pode promover a floculação, com contração das partículas argilosas, ou a dispersão, responsável pela expansão das mesmas partículas. A título de exemplo, para o entendimento do processo, pode-se dizer que ao ocorrer a redução da espessura da dupla camada elétrica, há um aumento na força atrativa entre as partículas com conseqüente floculação das partículas argilosas. Esta mudança na estrutura do solo aumenta seu volume de vazios e, conseqüentemente, implica em um aumento da compressibilidade e condutividade hidráulica. Em contrapartida, há uma diminuição na resistência ao cisalhamento do solo. 


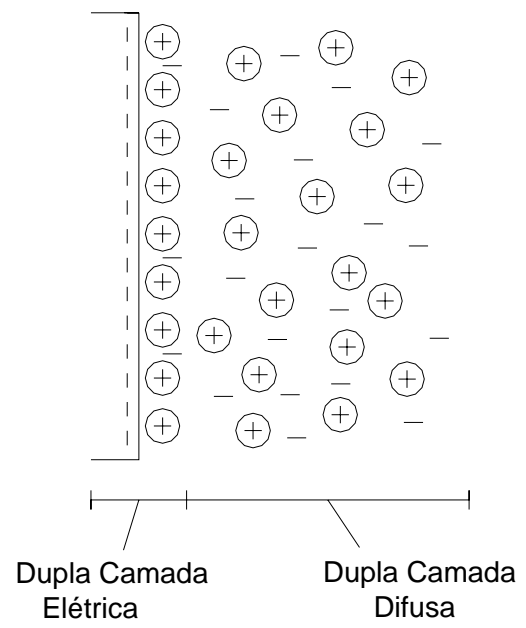

(a)

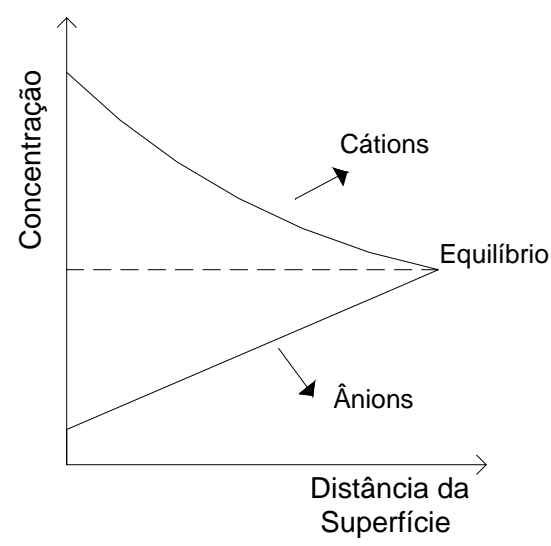

(b)

Figura 3.9. Formação da dupla camada elétrica e dupla camada difusa junto à superfície de uma partícula com cargas negativas (MITCHELL, 1993).

De acordo com Lambe (1958), os fatores que promovem a redução da dupla camada elétrica são os seguintes:

- Decréscimo da constante dielétrica do líquido;

- Aumento na concentração eletrolítica;

- Substituição de cátions de menor valência por de maior valência;

- Aumento da temperatura;

- Redução no tamanho do íon hidratado;

- Decréscimo do $\mathrm{pH}$;

- Decréscimo na adsorção de ânions.

A dupla camada elétrica também está relacionada com os processos de atenuação do contaminante através do solo. A superfície do argilomineral, ao ser polarizada eletricamente, atrai os solutos (íons) de carga oposta existentes no contaminante, aderindo-os em sua superfície. Este fenômeno provoca a diminuição da concentração das soluções contaminantes que adentram o sistema, retardando a frente de contaminação.

\subsubsection{Mecanismos de Interação}

De acordo com Yong et al. (1992), para o entendimento do mecanismo de interação existente entre os contaminantes e as partículas sólidas do solo, é necessário conhecer a composição do contaminante, além de identificar e determinar as características do 
solo. Os mecanismos são baseados no simples processo de transferência ou remoção do soluto da fase líquida para a fase sólida do sistema solo-contaminante. Os principais processos são:

- Sorção

Segundo Bedient et al. (1994), o processo de sorção pode ser definido como a interação do contaminante com a fase sólida do solo, podendo ser dividido em adsorção e absorção. O primeiro se refere à concentração do contaminante na superfície do solo, enquanto o segundo está relacionado à penetração e ao conseqüente acúmulo do contaminante no interior da matriz do solo. Como há poucas informações em relação à natureza específica desta interação, o termo sorção é usado genericamente englobando ambos os processos.

As reações de adsorção podem ser classificadas em adsorção física e adsorção química. O processo de adsorção física, segundo Yong et al. (1992), ocorre quando solutos são atraídos para a superfície das partículas sólidas em resposta às forças elétricas atrativas. Como esta interação está relacionada diretamente às forças eletrostáticas, o conceito da dupla camada difusa pode ser utilizado para o entendimento do processo.

O fenômeno da adsorção física pode ser representado pela Figura 3.10. Considerase uma partícula de argila, com superfície carregada com cargas negativas e previamente ligada a cátions $\mathrm{Na}^{+}$. Esta partícula argilosa é imersa em uma solução composta por íons $\mathrm{Pb}^{+2}$. Observa-se no instante (1) que algumas cargas negativas apresentam-se sem estar ligada aos cátions $\mathrm{Na}^{+}$. No instante (2), em virtude das forças eletrostáticas, os cátions $\mathrm{Pb}^{+2}$ disponíveis na solução se encontram adsorvidos na superfície da argila.

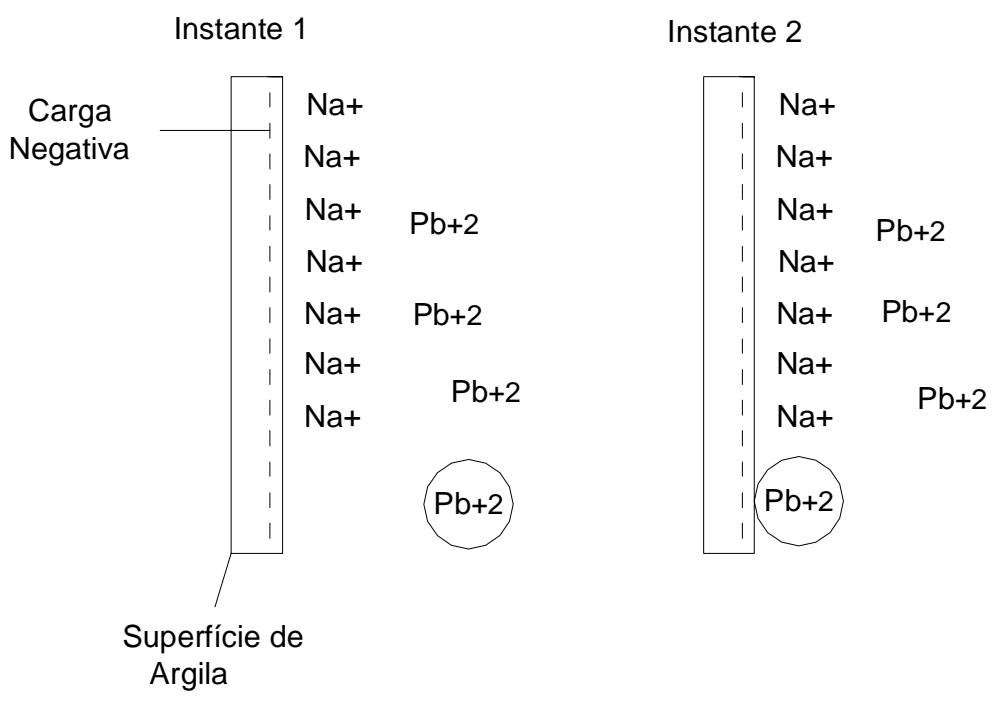

Figura 3.10. Processo de adsorção física (LEITE, 2001). 
Em relação à adsorção química, Yong et al. (1992) comenta que este processo está relacionado a um tipo de adsorção específica de alta afinidade, onde o soluto reage quimicamente com as partículas sólidas do solo por meio de fortes ligações químicas (iônicas, covalentes e coordenadas-covalentes).

\section{- Troca Iônica}

O processo de troca iônica se assemelha ao de adsorção física. Ambos os processos apresentam atração eletrostática quando ocorrem mudanças na composição da solução. O processo de troca iônica promove a troca de íons entre a superfície das partículas e a solução. Esta permuta está relacionada às diferenças de valência, estrutura cristalina e raio hidratado entre os íons. A Figura 3.11 apresenta o processo de troca iônica dos cátions $\mathrm{Na}^{+}$ por cátions $\mathrm{Pb}^{+2}$.

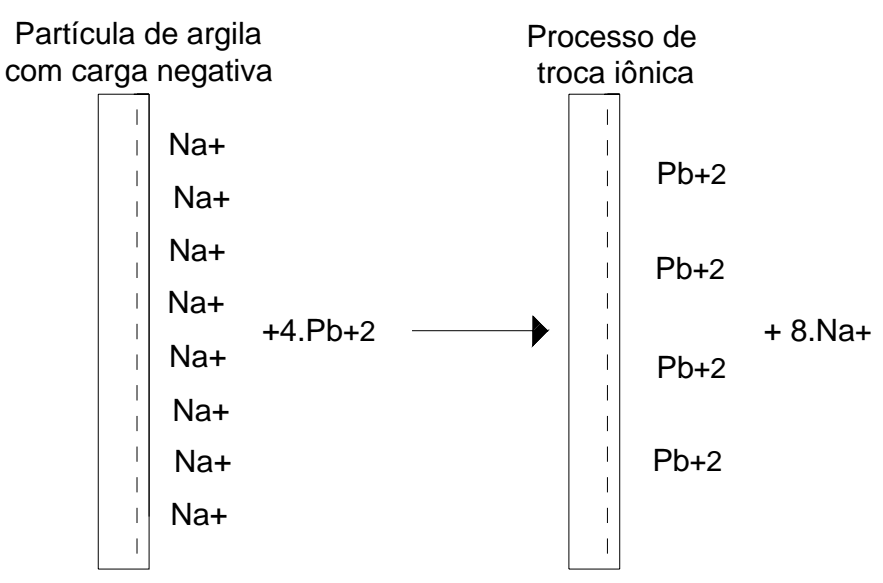

Figura 3.11. Processo de troca iônica (YONG et al.,1992).

Nota-se que a valência do cátion é uma característica fundamental neste processo. Yong et al. (1992) menciona que quanto maior for a valência do cátion, maior será seu poder de substituição. Da mesma forma, quanto maior a valência do cátion preso à superfície da argila, mais difícil será substituí-lo. Para casos específicos de íons que apresentam a mesma valência, o critério de substituição passa a ser o tamanho do íon, onde, quanto maior o tamanho, maior será o poder de substituição.

\section{- Complexação}

A complexação ocorre quando um cátion metálico reage com ânions que funcionam como ligantes inorgânicos $\left(\mathrm{OH}^{-}, \mathrm{Cl}^{-}, \mathrm{SO}_{4}^{-}, \mathrm{CO}_{3}{ }^{-2}, \mathrm{PO}_{3}^{-3}\right.$, entre outros). As ligações 
são do tipo covalente e são mais frágeis que as ligações formadas com ligantes orgânicos (YONG et al., 1992).

\section{- Precipitação}

A precipitação pode ser conceituada como um processo inverso à dissolução. A interação entre o contaminante e algum elemento químico existente na solução forma uma nova substância insolúvel, que se precipita. Tal fenômeno pode ocorrer tanto na superfície dos sólidos do solo, quanto nos seus poros preenchidos com água.

- Oxidação-Redução

As reações químicas de oxidação-redução (redox) são causadas pela transferência de elétrons entre duas substâncias. Estas reações ocorrem ativamente em solos com cargas variáveis. Tal fato decorre das condições de alta temperatura e alta precipitação, pois a decomposição da matéria orgânica libera elétrons que promovem a ocorrência destas reações de redução (LIU et al., 1997).

O potencial de redox pode ser determinado através do coeficiente $E h$, expresso em volts. Altos valores de $E h$ evidenciam pouca atividade eletrônica, espécies químicas pobres em elétrons (oxidados), enquanto os baixos valores indicam alta atividade eletrônica, ou seja, espécies sofrendo redução (ganhando elétrons).

\subsection{REALIZAÇÃO DO TRANSPORTE E ADSORÇÃO DE CONTAMINANTES EM LABORATÓRIO}

A determinação de características geológicas e geotécnicas relativas ao transporte de contaminantes é de fundamental importância para a caracterização de locais e elaboração de projetos para obras destinadas à disposição de resíduos e rejeitos. Atualmente, o ensaio que representa de forma mais realista as condições ocorridas em campo, tanto em transporte de contaminantes quanto no processo de atenuação em materiais naturais, é o ensaio de percolação em coluna.

Este ensaio, segundo Shackelford (1994), pode ser utilizado para o entendimento dos mecanismos químicos e físicos que afetam o transporte de contaminantes no ambiente. $\mathrm{O}$ objetivo do ensaio é a determinação das características de adsorção do solo frente à percolação de soluções químicas (contaminantes) que permeiam através de amostras de solo. 
Ao analisar a composição do efluente que foi percolado através do solo, e comparando-o com a concentração original da solução, é possível quantificar quanto ficou retido pelo solo. Assim, pode-se estimar o tempo de vida útil de uma barreira, e ainda quantificar o tempo máximo para utilização de um sítio de disposição.

\subsubsection{Parâmetros Obtidos com a Realização dos Ensaios de Percolação em Colunas}

Os resultados dos ensaios de percolação em colunas de solos são apresentados em forma de gráficos denominados curvas de chegada. A curva de chegada ilustra os mecanismos de transporte de contaminantes predominantes e o processo de atenuação do contaminante pelo solo. A verificação destas propriedades depende das características do soluto, ou seja, se é reativo ou não com o solo. A Figura 3.12 apresenta curvas de chegada típicas para solutos não reativos e reativos.

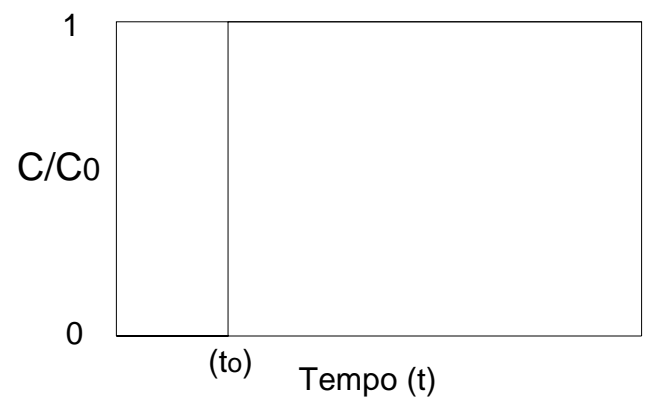

(a)

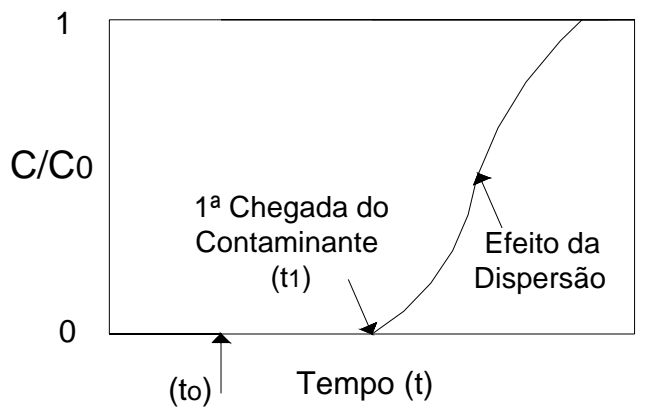

(b)

Figura 3.12. Tipos de curvas de chegada: (a) soluto não reativo - transporte advectivo; (b) soluto reativo - efeito da dispersão hidrodinâmica (FREEZE; CHERRY, 1979 - modificado).

Ao analisar a Figura 3.12 (a), referente a um soluto não reativo, observa-se que após um certo tempo $\left(t_{0}\right)$ a concentração final permanece igual a inicial. Esta situação, representada pela forma em degrau da curva de chegada, demonstra que o transporte de contaminante ocorre por advecção. Na Figura 3.12 (b), a curva de chegada apresenta-se na forma de "S", mostrando o transporte de contaminante por dispersão hidrodinâmica e indicando a ocorrência de adsorção dos solutos pelo solo (solutos reativos).

Os parâmetros que podem ser obtidos por meio de ensaios de percolação em colunas estão apresentados na Tabela 3.3: 
Tabela 3.3. Parâmetros que podem ser determinados a partir de ensaios de percolação em colunas.

\begin{tabular}{|c|c|c|}
\hline Parâmetro & Forma de Obtenção & Características Gerais \\
\hline Fator de Retardamento (Rd) & $\begin{array}{l}\text { (1) Diretamente da curva de } \\
\text { chegada, para um valor de } T_{p} \\
\text { correspondente a C/C0 }=0,5 \\
\text { (FREEZE; CHERRY, 1979) } \\
\text { (2) Calculado a partir da área } \\
\text { acima da curva de chegada } \\
\text { (SCHACKELFORD, 1994). }\end{array}$ & $\begin{array}{l}\text { (1) Indicado para altas taxas } \\
\text { de fluxo, ou seja, solos de alta } \\
\text { permeabilidade. } \\
\text { (2) Indicado para baixas taxas } \\
\text { de fluxo, ou seja, solos de } \\
\text { baixa permeabilidade. }\end{array}$ \\
\hline $\begin{array}{c}\text { Coeficiente de Dispersão } \\
\text { Hidrodinâmica } \\
\text { (Dh) }\end{array}$ & $\begin{array}{l}\text { Pode ser determinada das } \\
\text { seguintes formas: soluções } \\
\text { analíticas, modelagem de } \\
\text { curvas teóricas e relações } \\
\text { empíricas. }\end{array}$ & $\begin{array}{l}\text { Representa a somatória das } \\
\text { componentes: difusão efetiva e } \\
\text { dispersão mecânica. }\end{array}$ \\
\hline Número de Peclet (Pl) & $\begin{array}{l}\qquad P l=\frac{L v}{D_{h}} \\
\text { (SHACKELFORD, 1994). } \\
\text { onde: } L=\text { comprimento da } \\
\text { coluna; } v=\text { velocidade linear } \\
\text { média; } D_{h}=\text { coeficiente de } \\
\text { dispersão hidrodinâmica. }\end{array}$ & $\begin{array}{l}\text { Parâmetro que identifica o } \\
\text { mecanismo de transporte } \\
\text { predominante: } \\
\text { - Para valores de } \mathrm{Pl} \geq 50 \text {, } \\
\text { transporte por advecção; } \\
\text { - Para valores de } \mathrm{Pl} \leq 1 \text { : } \\
\text { Transporte por difusão } \\
\text { molecular. }\end{array}$ \\
\hline
\end{tabular}

Maiores detalhes em relação a este ensaio, bem como sua metodologia de execução, pode ser verificada no Capítulo 4.

\subsection{CONDUTIVIDADE HIDRÁULICA DOS SOLOS UTILIZADOS EM LINERS}

A determinação da condutividade hidráulica é um requisito básico para garantir a segurança construtiva e operacional dos liners. Diversos autores estabelecem que os valores de condutividade hidráulica máxima para solos compactados, devem se apresentar na ordem de $10^{-9} \mathrm{~m} / \mathrm{s}$. Neste sentido, observa-se que para a grande maioria dos engenheiros a condutividade hidráulica e o teor de umidade de compactação são parâmetros determinantes na escolha dos materiais para esta finalidade.

É comum haver confusão, principalmente no meio geotécnico, sobre a utilização dos termos condutividade hidráulica e coeficiente de permeabilidade. Tal fato se deve a utilização desses dois termos em vários ramos da ciência (hidrologia, agronomia, física do solo, engenharia civil, etc.). Para se evitar dúvidas em relação à utilização de uma ou de outra nomenclatura, torna-se necessário defini-las.

Freezy e Cherry (1979) citam que o coeficiente de permeabilidade (permeabilidade intrínseca ou específica) depende somente das características do meio, ou seja, da abertura média dos poros existentes no solo. Em contrapartida, a condutividade hidráulica depende não somente do meio percolado (abertura média dos poros), mas também 
das características do fluido, como densidade e viscosidade. As duas definições podem ser representadas pelas equações a seguir:

$$
\begin{gathered}
k=C_{p} d_{c}{ }^{2} \\
\mathrm{e} \\
K=\frac{k \rho g}{\mu}
\end{gathered}
$$

Na Equação 9, o termo $k$ é denominado de coeficiente de permeabilidade intrínseca, $C_{p}$ é uma constante de permeabilidade que considera algumas propriedades do meio poroso que também afetam o fluxo, tais como a granulometria, o grau de esfericidade e a natureza do solo e $d_{c}$ é o diâmetro do canal do poro percolado. Na Equação 10 o termo $K$ é a condutividade hidráulica, $\rho$ é a densidade do fluido percolado, $\mu$ é o coeficiente de viscosidade dinâmica do fluido e $g$ é a aceleração da gravidade. Nesta dissertação, mediante as definições apresentadas, o parâmetro $k$ será convencionalmente chamado de condutividade hidráulica.

Vários autores vêm estudando e analisando os fatores que interferem na condutividade hidráulica dos liners. Dentre os vários trabalhos existentes nesta linha de pesquisa, pode-se citar alguns, onde maiores informações podem ser encontradas em relação a este assunto, entre os quais: Lambe (1958); Day e Daniel (1985); Benson e Daniel (1990); Sharma e Lewis (1994); Benson; Zhai e Wang (1994) e Macambira (2002).

Entretanto, os sistemas de impermeabilização de aterros sanitários (liners) podem ser solicitados por acomodação e peso próprio dos resíduos, cargas pontuais e mudanças de temperatura. Como conseqüência destas solicitações e da sua forma de disposição, que pode tanto ser horizontal (proteção de fundo) quanto de forma inclinada (para proteger uma encosta ou talude), há necessidade de analisar sua estabilidade frente às tensões atuantes.

A Figura 3.13 apresenta várias superfícies potenciais de ruptura para diferentes tipos de aterros escavados para deposição de resíduos. Tais superfícies são apresentadas na Figura 3.13. 

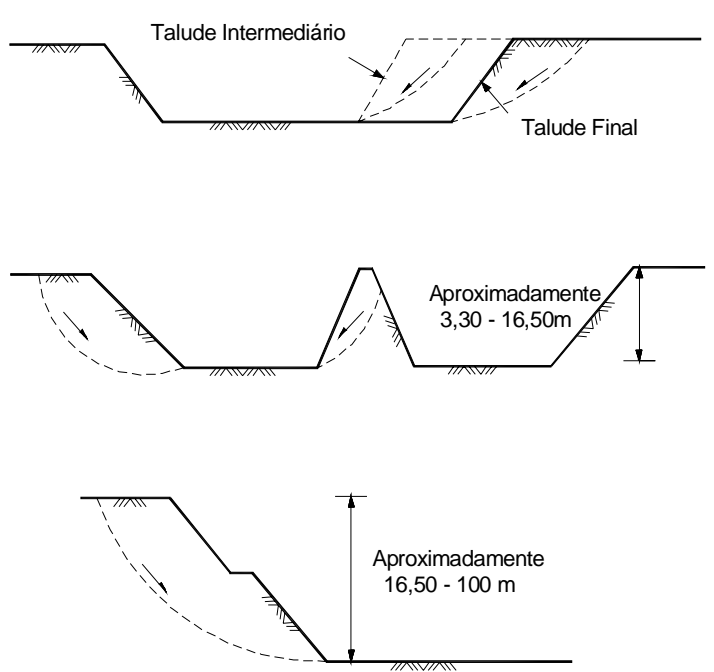

Figura 3.13. Plano de ruptura nos aterros escavados (SHARMA; LEWIS, 1994).

\subsection{RESISTÊNCIA AO CISALHAMENTO DOS SOLOS}

A Mecânica dos Solos clássica define a resistência ao cisalhamento como um limite de resistência à deformação oferecida por uma massa ou amostra de solo quando submetida a um carregamento ou descarregamento (HEAD,1986). Para os solos, são geralmente considerados apenas os casos de solicitação por cisalhamento, pois as deformações em um maciço de terra são resultantes de deslocamentos relativos entre as partículas constituintes dos maciços.

O estudo da resistência ao cisalhamento de um solo pode ser realizado em campo e em laboratório. Dentre os ensaios de campo, o Vane Test (também conhecido como ensaio de palheta) e os ensaios de cone, em que a medida de resistência à penetração usualmente é relacionada com a resistência ao cisalhamento do solo, são os mais difundidos para esta finalidade. Com relação aos ensaios laboratoriais, os mais empregados são o ensaio de cisalhamento direto e o ensaio de compressão triaxial.

O ensaio de compressão triaxial permite um maior controle das condições a que o solo é submetido, o que permite simular as mais variadas situações ocorridas em campo. Apresentam-se como vantagens o controle das condições de drenagem e a possibilidade de medição das pressões neutras geradas.

\subsubsection{Ensaio Triaxial}

O ensaio de compressão triaxial consiste na aplicação de um estado hidrostático de tensões (tensão de confinamento) e de um carregamento axial sobre um corpo de prova 
cilíndrico de solo. O corpo de prova é envolto por uma membrana impermeável, e é colocado no interior de uma câmara como mostra a Figura 3.14. A câmara é preenchida com água, à qual se aplica uma pressão, que confina o corpo de prova. Durante este período, o corpo de prova pode ser adensado ou não. Após esta etapa, mantendo-se o estado hidrostático de tensões, dá-se inicio ao cisalhamento, através de um carregamento vertical aplicado por meio de um pistão.

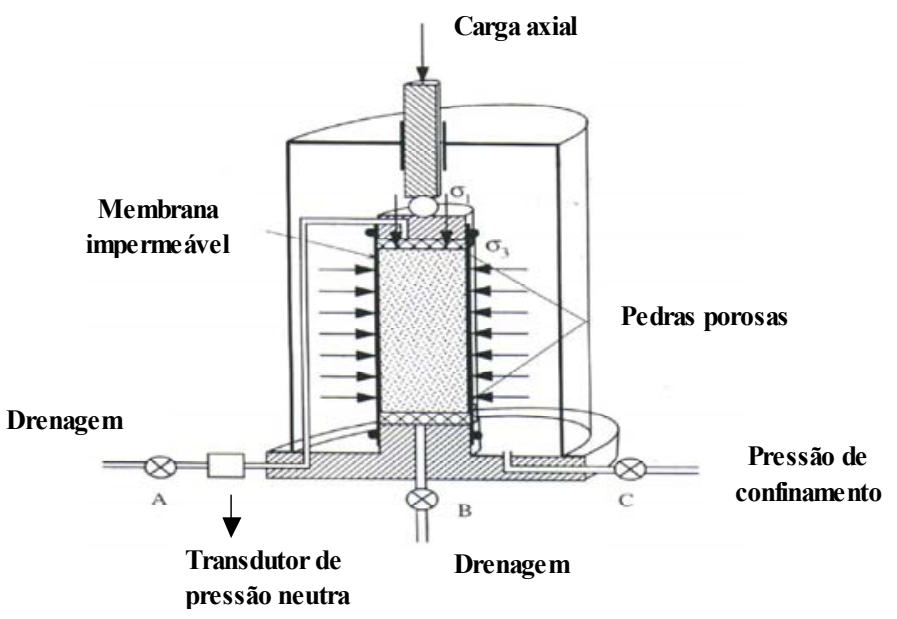

Figura 3.14. Esquema típico de um ensaio triaxial (BARDET, 1997).

As diversas conexões da câmara triaxial com o exterior são responsáveis pelas condições de drenagem impostas durante o ensaio, sendo assim, determinantes nas variadas maneiras que o ensaio pode ser realizado.

As variações dos ensaios triaxiais são descritas abaixo, segundo Craig (1992):

- Ensaio não adensado e não drenado (UU): a amostra é submetida à pressão de confinamento $\left(\sigma_{3}\right)$ e a seguir, de forma imediata, a tensão deviatória $\left(\sigma_{1}-\sigma_{3}\right)$ é aplicada. Durante essas duas fases não é permitida a drenagem do corpo de prova.

- Ensaio adensado e não drenado (CU): a drenagem do corpo de prova é permitida durante a aplicação da pressão de confinamento $\left(\sigma_{3}\right)$, até que o adensamento se processe de forma completa. Posteriormente, a tensão desvio $\left(\sigma_{1}-\sigma_{3}\right)$ é aplicada sem permissão de drenagem. Medidas de pressão neutra podem ser medidas durante a fase não drenada do ensaio.

- Ensaio adensado e drenado (CD): a drenagem do corpo de prova é permitida durante a aplicação da pressão de confinamento $\left(\sigma_{3}\right)$, até que o adensamento 
se processe de forma completa. Ainda com a permissão da drenagem, a tensão desvio $\left(\sigma_{1}-\sigma_{3}\right)$ é aplicada e aumentada a uma razão suficiente para que a pressão neutra seja mantida igual a zero.

O fluxograma apresentado na Figura 3.15 sintetiza as formas como os ensaios triaxiais podem ser realizados:

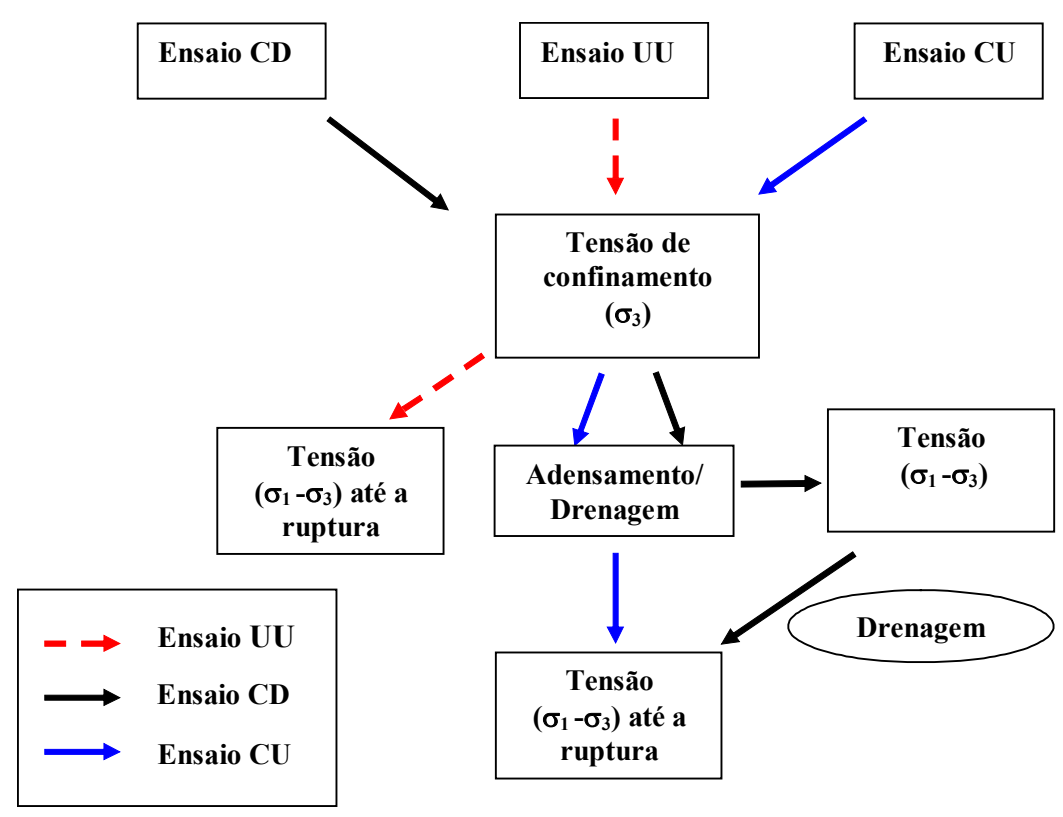

Figura 3.15. Fluxograma que sintetiza os tipos de ensaio triaxial.

\subsubsection{Saturação por Contra Pressão}

A presença de bolhas de ar nos vazios do solo dificulta a determinação da pressão neutra durante a realização dos ensaios triaxias. Este inconveniente pode ser evitado com a completa saturação da amostra. O procedimento que é utilizado para promover a saturação é conhecido como saturação por contra pressão.

De acordo com Head (1986), a saturação é atingida quando a pressão neutra (contra pressão) é aumentada até um nível suficiente que permita que as bolhas de ar possam ser absorvidas (dissolvidas) pela solução aquosa existente nos vazios do solo. Atinge-se esta condição, aplicando-se incrementos de mesma magnitude tanto para a tensão confinante quanto para a contra pressão, mas deixando a contra pressão um pouco inferior à tensão confinante para manter uma pequena tensão efetiva na amostra. Quando se dá a saturação da amostra, a pressão neutra (contra pressão) deve ser mantida, já que a redução da mesma, implicaria no reaparecimento de bolhas de ar nos vazios do solo. 
Head (1986) apresenta as vantagens de se utilizar à saturação por contra pressão:

- Não há separação entre as fases ar-água, já que o ar acaba dissolvido na solução aquosa, evitando erros nas medidas de pressão neutra;

- Qualquer bolha de ar existente entre a membrana e o solo será dissolvida;

- Em amostras que sofrem aumento de volume (dilatação) durante a fase de cisalhamento, a aplicação de elevada contra pressão, implica na permanência da pressão neutra positiva. Tal fato minimiza a possibilidade das amostras apresentarem valores de pressão neutra inferiores a $150 \mathrm{kPa}$.

- Qualquer bolha de ar remanescente nos sistemas de aplicação de contra pressão e medida de pressão neutra serão eliminados, evitando que bolhas de ar impeçam a drenagem da amostra.

\subsubsection{Determinação da Envoltória de Resistência}

É pratica comum relacionar as condições de ruptura de um solo a uma máxima Tensão desvio $\left(\sigma_{1}-\sigma_{3}\right)$ máx. Salienta-se, entretanto, que existem outros critérios para a definição da ruptura. Head (1986) menciona que existem cinco critérios para se determinar a ruptura de um corpo de prova submetido a um ensaio triaxial:

- Tensão desviatória máxima $\left(\sigma_{1}-\sigma_{3}\right)_{\operatorname{máx}}$;

- Razão máxima entre as tensões principais efetivas $\left(\sigma_{1}{ }_{1} / \sigma^{\prime}{ }_{3}\right)$;

- Deformações máximas permitidas;

- Resistência para volume constante, ou seja, condição de estado crítico;

- Resistência Residual.

Pode-se, após ensaiar corpos de prova com diferentes tensões confinantes, determinar a envoltória de resistência por meio de círculos de Mohr na ruptura. Dependendo do tipo de ensaio é possível obter os parâmetros de resistência tanto em termos de tensões totais $(c, \phi)$, como em tensões efetivas $\left(c^{\prime}, \phi^{\prime}\right)$.

Souza Pinto (2002) comenta que quando se pretende representar o estado de tensões de um solo em diversas fases de carregamento, os diversos círculos de Mohr podem representar bem a evolução das tensões. Mas, quando, as duas tensões principais variam simultaneamente, esta representação pode se tornar confusa, procedendo-se então, à sistemática de representar as diversas fases de carregamento pela representação exclusiva dos 
pontos de maior ordenada da cada circulo, ligando-os por uma curva denominada de trajetória de tensões.

Sendo $p$ e $q$ as coordenadas dos pontos da trajetória, por sua definição, tem se:

$$
\begin{gathered}
p=\frac{\sigma_{1}+\sigma_{3}}{2} \\
\mathrm{e} \\
q=\frac{\sigma_{1}-\sigma_{3}}{2}
\end{gathered}
$$

onde:

$p=$ média das tensões principais;

$q=$ semidiferença das tensões principais.

Pode-se, também, definir $p$ e $q$, como tensão normal e a tensão cisalhante no plano de máxima tensão cisalhante, respectivamente.

No plano $p-q$ a envoltória é uma reta determinada pela seguinte equação:

onde:

$$
q=a+p \times \operatorname{tg} \alpha
$$

$a=$ intercepto da envoltória no plano $p-q$;

$\alpha=$ declividade da envoltória.

Os parâmetros de resistência obtidos a partir da envoltória $a$ e $\alpha$ podem ser diretamente relacionados aos parâmetros de resistência de Mohr Coulomb ( $c$ e $\phi)$, através das seguintes relações (CRAIG, 1992):

$$
\begin{gathered}
\operatorname{sen} \phi=\operatorname{tg} \alpha \\
c=\frac{a}{\cos \phi}
\end{gathered}
$$

As Equações (14) e (15) são válidas tanto para tensões totais como para as tensões efetivas. 


\subsection{COMPORTAMENTO MECÂNICO DE SOLOS CONTAMINADOS}

Conhecendo-se todas as etapas e conceitos envolvidos no processo, a verificação da influência do contaminante no comportamento mecânico dos solos, se torna mais acessível e interessante. São poucos os trabalhos científicos que abordam de forma mais específica este tema. A seguir são mencionados alguns trabalhos relacionados ao assunto.

Al - Sanad e Ismael (1995) examinaram o comportamento de areias contaminadas por óleo, provenientes da explosão de poços de óleo no Kuwait, ao final da guerra do Golfo. Programas de ensaios laboratoriais foram realizados para se determinar as características geotécnicas deste material. A areia estudada foi classificada como uma areia mal graduada e apresentou quantidade típica de finos e quartzo na sua composição. O solo foi misturado a quatro tipos de óleo, mas, os resultados apresentados são referentes às amostras misturadas com 6\% (em relação ao seu peso específico seco) de óleo. Os ensaios realizados foram: ensaios de cisalhamento direto, ensaio de compressão triaxial do tipo (CU) com medida de pressão neutra e ensaios de adensamento. Todos os ensaios foram realizados imediatamente após o processo de contaminação das amostras. A areia contaminada apresentou diminuição da permeabilidade e da resistência do solo. Entretanto, as reduções não foram significativas, representando cerca de $2^{\circ}$ no ângulo de atrito, para amostras preparadas com uma densidade relativa de $60 \%$ e misturado com $6 \%$ de óleo cru.

Os mesmos autores, em 1997, realizaram os mesmos ensaios, mas em períodos de tempos sucessivos, ou seja, imediatamente após a contaminação e posteriormente, em períodos de um, três e seis meses. As amostras ensaiadas após o período de seis meses apresentaram perda de componentes voláteis de óleo. Tal ocorrência provocou aumento na resistência e rigidez do solo comparado com as amostras dos outros períodos (um e três meses). Porém, em relação às areias sem contaminante, a resistência permaneceu inferior.

Costa Jr. (2001) estudou o efeito da soda cáustica, em diferentes concentrações, no comportamento tensão-deformação-resistência de um solo laterítico. As amostras foram classificadas como areias finas siltosas, com predomínio de argilominerais menos ativos, pertencentes ao grupo das caulinitas. As propriedades mecânicas foram determinadas a partir de ensaios triaxiais do tipo adensado e drenado (CD), com deformação controlada. A resistência ao cisalhamento não apresentou variações significativas, comparando-se aos ensaios realizados com amostras percoladas somente água.

Corrêa e Souza (2002) realizaram estudos em três tipos de solos tropicais, retirados de duas áreas potenciais para disposição de resíduos sólidos industriais no Distrito 
Federal. Os solos amostrados foram diferenciados quanto ao horizonte de intemperismo de origem e identificados como: solo laterítico, zona mosqueada e saprolito. As amostras de solo foram compactadas com teor de umidade acima do ótimo, submetidas a ensaios de coluna com permeâmetro de parede rígida com percolação de água destilada, solução salina a 1000 ppm $\mathrm{NaCl}$ e chorume. Os ensaio de granulometria, sucção do solo, expansão livre e limites de consistência, indicaram um rearranjo das partículas de solo, aumentando a quantidade de partículas discretizadas, com redução da condutividade hidráulica. Tal comportamento mostra indícios de que a infiltração do contaminante através do solo poderá ser dificultada.

Izzo (2003) realizou um trabalho, com objetivos de avaliar a técnica do ensaio triaxial em múltiplos estágios e estudar a influência da contaminação por cloreto de cobre aquoso, em diferentes concentrações (50,300 e $600 \mathrm{mg} / \mathrm{L})$, na resistência ao cisalhamento de um solo arenoso compactado oriundo da Formação Botucatu. Os resultados obtidos com a técnica de ensaios triaxiais em múltiplos estágios foram comparados com os resultados dos ensaios triaxiais convencionais do tipo adensado e não drenado (CU). Os parâmetros de resistência obtidos pela técnica do ensaio triaxial em múltiplos estágios apresentaram-se inferiores aos parâmetros de resistência obtidos com o ensaio triaxial convencional. Segundo o autor, os ciclos de carregamento e descarregamento sofridos pelos corpos de prova durante o ensaio, podem ter causado a ruptura prévia do corpo de prova. Portanto, esta técnica só pode ser considerada uma alternativa interessante quando é praticamente impossível ou inviável se obter amostras em quantidades suficientes para a realização de ensaios triaxiais convencionais.

Da análise dos resultados dos ensaios triaxiais convencionais, o autor constatou uma pequena redução da tensão de ruptura devido à contaminação. Este efeito foi mais pronunciado para as tensões de confinamento de 50 e $100 \mathrm{kPa}$. Em relação aos parâmetros de resistência, observou-se uma maior redução da coesão efetiva para o solo percolado com as concentrações de 50 e $300 \mathrm{mg} / \mathrm{L}$ de cloreto de cobre aquoso. Não houve uma variação significativa do ângulo de atrito e no módulo de deformabilidade $\left(E_{50}\right)$ provocada por essa contaminação. Mediante aos resultados obtidos, o autor concluiu que a influência da contaminação na resistência e na rigidez foi pouco significativa e não precisa ser considerada para o solo estudado, para fins de aplicação prática. 


\subsection{INTRODUÇÃO}

O programa experimental desta pesquisa foi realizado nos Laboratórios de Mecânica dos Solos e de Geotecnia Ambiental do Departamento de Geotecnia da Escola de Engenharia de São Carlos-USP. Neste capítulo, serão abordados os detalhes referentes à coleta, à caracterização dos solos e às metodologias utilizadas para a realização dos ensaios.

\subsection{METODOLOGIA}

Inicialmente, foram realizadas a coleta, a preparação da mistura na dosagem prédefinida e a caracterização dos solos. As características mineralógicas e físico-químicas foram previamente determinadas por Basso (2003). Em seguida, os solos foram compactados em segmentos de tubo de PVC (colunas) e submetidos aos ensaios de percolação. Estes ensaios foram realizados de modo que houvesse a completa adsorção do contaminante pelo solo. $\mathrm{Na}$ terceira e última etapa, os corpos de prova foram então retirados das colunas de percolação e convenientemente talhados para a realização dos ensaios triaxiais convencionais do tipo CU. A seqüência metodológica adotada está representada pelo fluxograma de atividades mostrado na Figura 4.1. 


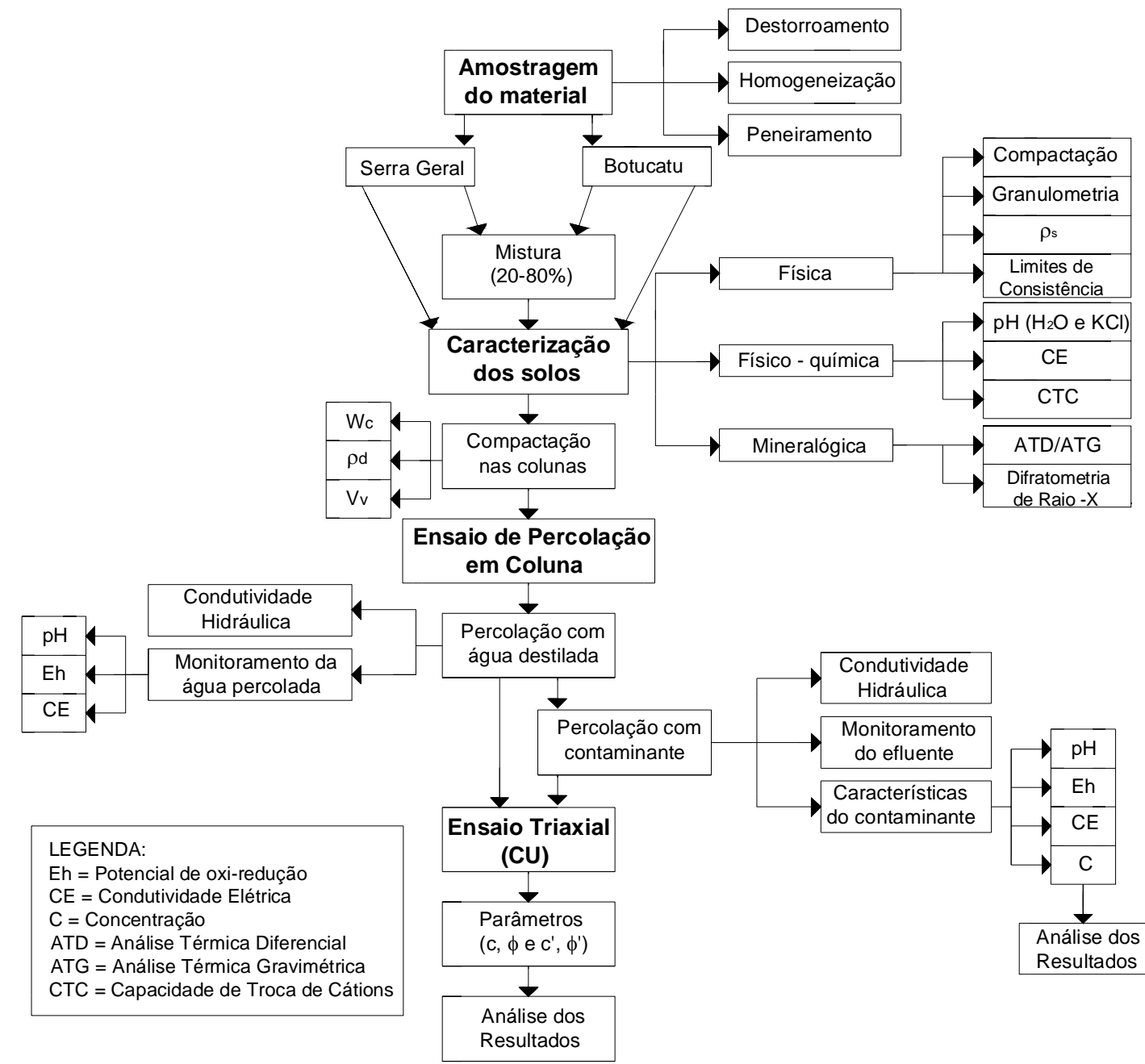

Figura 4.1. Fluxograma de atividades.

\subsection{AMOSTRAGEM DO MATERIAL}

Os solos estudados foram coletados no município de São Carlos, sendo provenientes das coberturas de material inconsolidado das Formações Botucatu e Serra Geral (Figura 4.2). Por simplicidade, estes solos serão denominados nesta dissertação, de solo Serra Geral e solo Botucatu.

O solo Serra Geral foi coletado em um talude lateral da rodovia que liga São Carlos a Ribeirão Bonito no sentido Ribeirão Bonito - São Carlos (Figura 4.3). O local apresenta as coordenadas UTM 7.557.026 m e $198.732 \mathrm{~m}$ (Zona 23S). O solo Botucatu foi coletado por Basso (2003) em um porto de areia denominado Mineração Itaporanga, localizado no Km 154 da estrada São Carlos-Ribeirão Bonito, com coordenadas UTM 7.557.355 m e 198.152 m (Zona 23S) (Figura 4.4). 


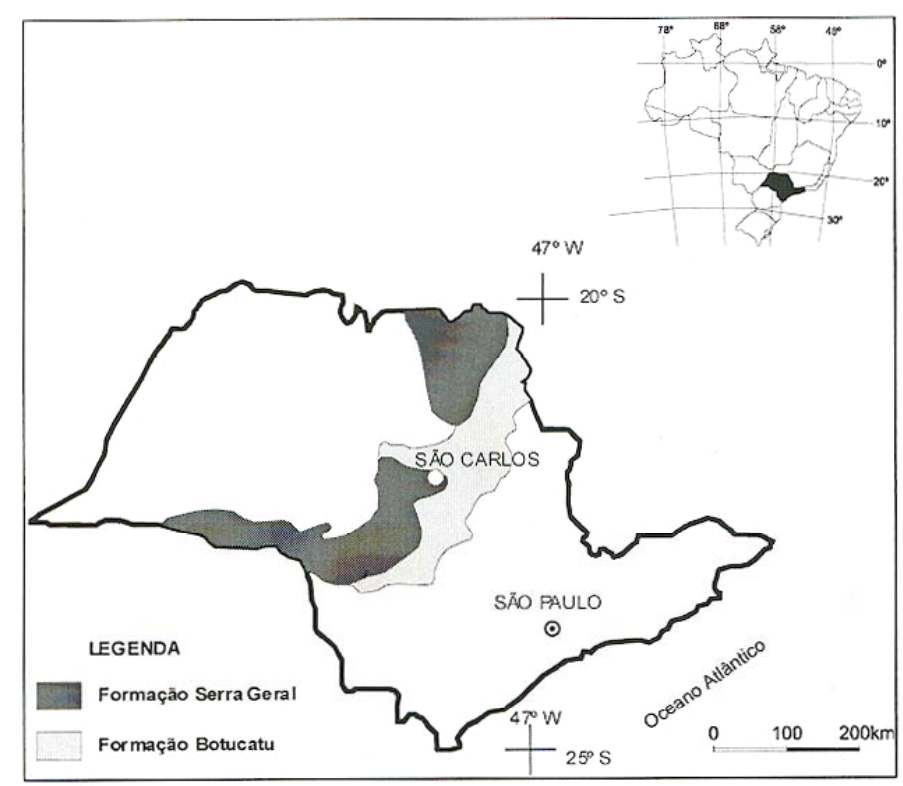

Figura 4.2. Localização dos solos estudados (BASSO, 2003).

A coleta do solo Serra Geral (aproximadamente $250 \mathrm{Kg}$ ) foi realizada à uma profundidade de $1,80 \mathrm{~m}$, enquanto que o solo Botucatu (aproximadamente $400 \mathrm{Kg}$ ), foi coletado a uma profundidade de aproximadamente $3,0 \mathrm{~m}$. A coleta das amostras deformadas foi realizada após uma cuidadosa limpeza do local, com a remoção da vegetação superficial e de toda camada externa submetida ao processo de ciclagem (umedecimento e secagem). Buscou-se assim, garantir uma maior homogeneidade dos solos.

As amostras coletadas foram levadas ao laboratório e preparadas sem secagem prévia. Inicialmente foram passadas através da peneira 4,8 $\mathrm{mm}$ (\#4), utilizando-se um tripé como acessório para facilitar o processo. Foi estendida uma lona sobre o chão, tomando-se os devidos cuidados para minimizar a perda de partículas finas durante o processo. Após o peneiramento, os solos foram armazenados em sacos plásticos e devidamente identificados para a realização dos ensaios. 


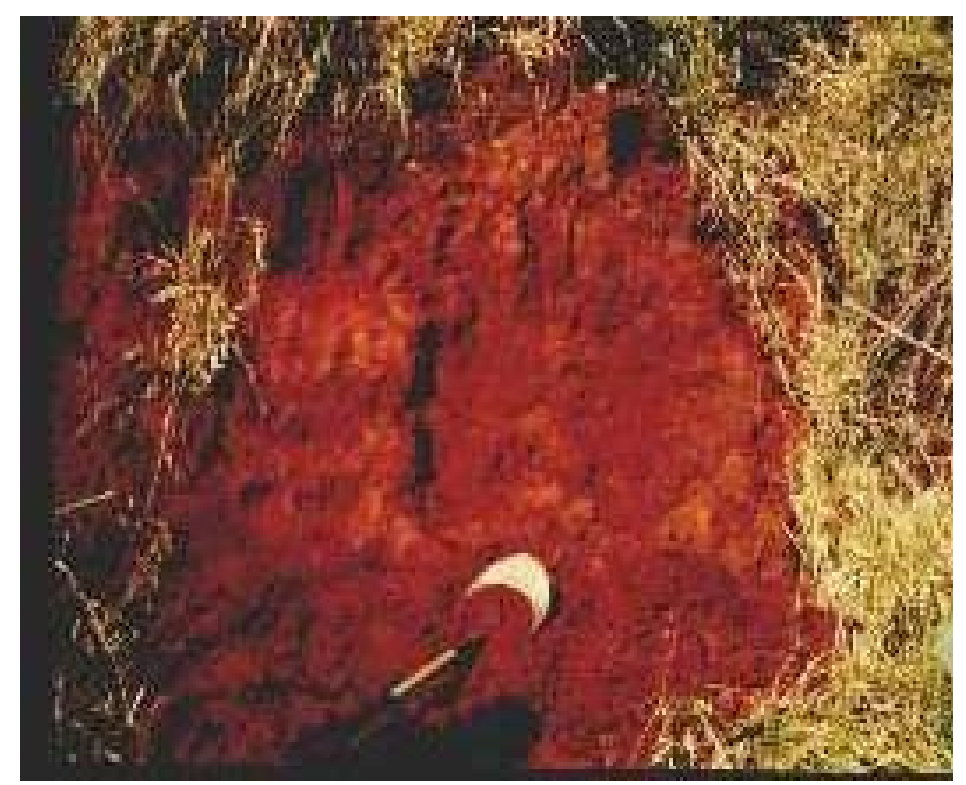

Figura 4.3. Coleta do solo Serra Geral.

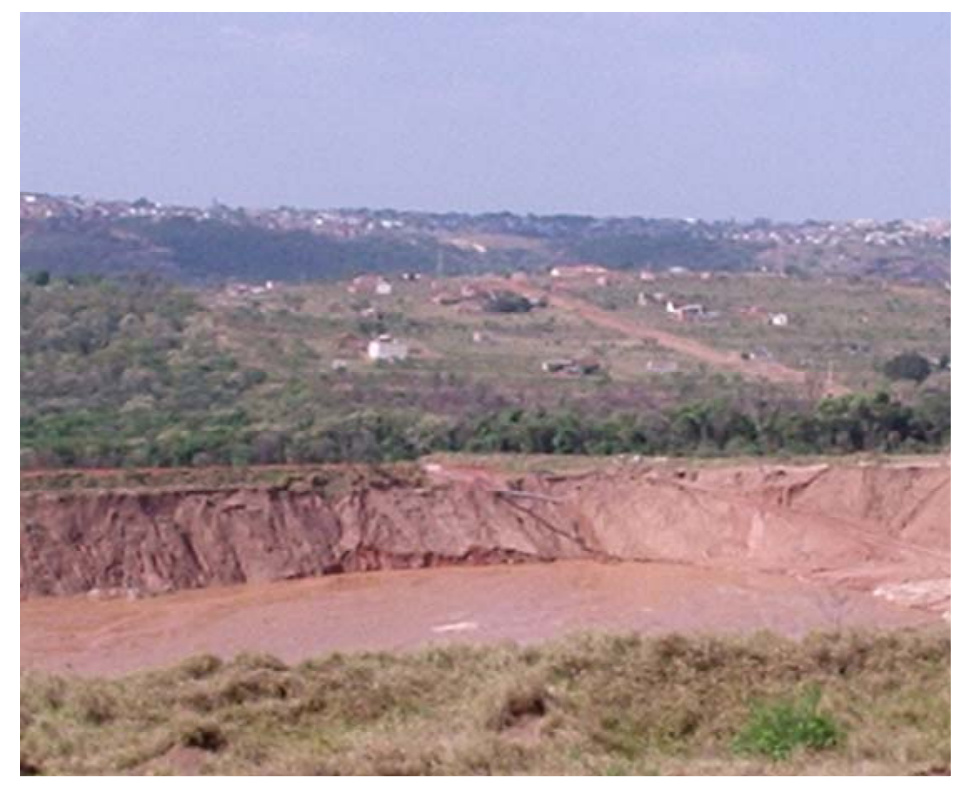

Figura 4.4. Mineração Itaporanga: local de coleta do solo Botucatu.

\subsection{PREPARAÇÃO DA MISTURA}

A mistura entre os solos Serra Geral e Botucatu foi preparada com o auxílio de uma betoneira elétrica de capacidade aproximada de $80 \mathrm{~kg}$. Em trabalhos anteriores, conforme relatado por Basso (2003), ocorreram problemas na preparação da mistura. Perda de finos para o ar durante o movimento de rotação da betoneira e falta de representatividade da amostra com a realização da mistura com quantidade de solo superior à capacidade da 
betoneira foram os principais problemas observados. Estes problemas foram constatados por meio do resultado do ensaio de ganulometria conjunta.

A preparação da mistura foi realizada da seguinte forma:

- Determinaram-se as umidades dos solos Botucatu $(0,40 \%)$ e Serra Geral $(8,4 \%)$ e preparou-se a mistura na dosagem pré-definida em relação à sua massa seca: $80 \%$ Botucatu e $20 \%$ Serra Geral.

- A mistura foi preparada com 80,0 kg de massa seca (capacidade da betoneira). Assim, evitaram-se os problemas de representatividade da amostra.

- Uma lona plástica foi cuidadosamente fixada na boca da betoneira para evitar perda de finos durante os trinta minutos de rotação.

- Após a sua preparação, a mistura foi armazenada em sacos plásticos para posterior utilização em ensaios.

\subsection{CARACTERIZAÇÃO DOS SOLOS}

Para caracterizar os solos estudados, foram realizados ensaios de caracterização geotécnica, ensaios de caracterização físico-química e ensaios de caracterização mineralógica. A caracterização geotécnica foi realizada por meio de ensaios de análise granulométrica conjunta, massa específica dos sólidos, limites de liquidez e plasticidade e compactação. A caracterização físico-quimica foi efetuada por Basso (2003) por meio de ensaios de capacidade de troca catiônica (C.T.C), superfície específica (S.E) e pH dos solos. A mineralogia dos solos foi determinada por ensaios de difração de raios-X e análise térmica diferencial.

\subsubsection{Análise Granulométrica Conjunta}

Os ensaios de granulometria conjunta para os solos Serra Geral, Botucatu e a mistura seguiram os procedimentos da Norma ABNT MB-32 (NBR 7181/84). Estes ensaios foram realizados em duas etapas: (1) peneiramento da fração grossa (pedregulho e areia) e (2) sedimentação da fração fina (silte e argila). Para a realização da segunda etapa utilizou-se uma solução química defloculadora das partículas, hexamatafosfato de sódio $\left(\mathrm{Na}_{3} \mathrm{PO}_{4}\right)_{\mathrm{n}}$. As peneiras utilizadas na etapa de peneiramento seguem o padrão da ABNT - EB - 22 (NBR $5734 / 80)$. 
As curvas de distribuição granulométricas obtidas para os solos Serra Geral, Botucatu e para a mistura, estão apresentadas nas Figuras 4.5, 4.6 e 4.7, respectivamente.

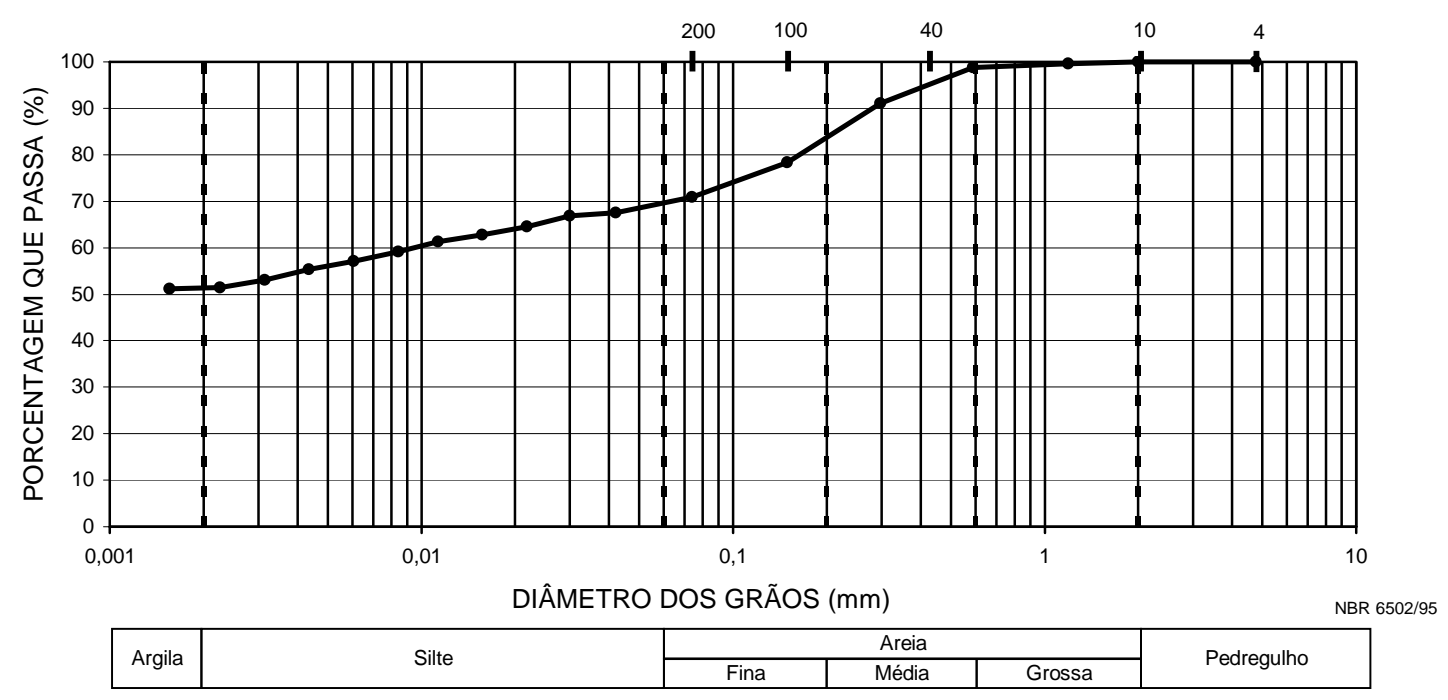

Figura 4.5. Curva de distribuição granulométrica para o solo Serra Geral.

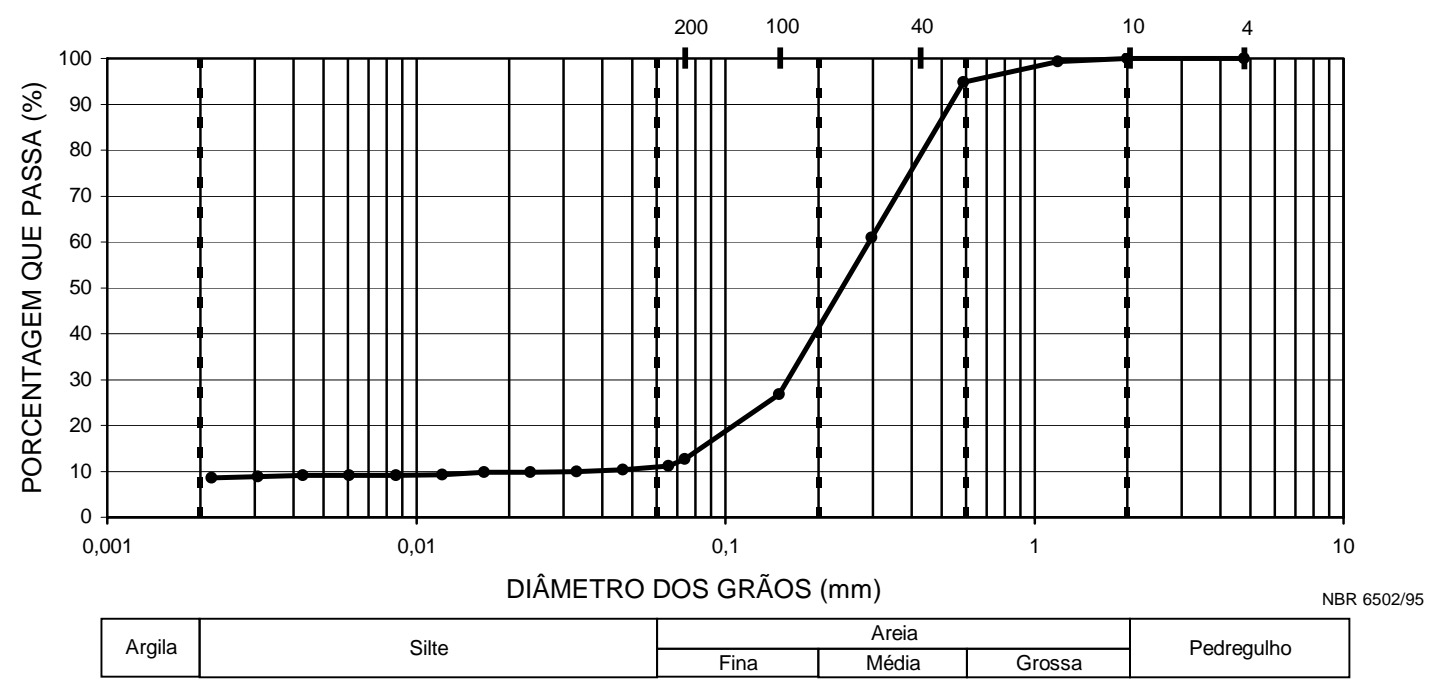

Figura 4.6. Curva de distribuição granulométrica para o solo Botucatu. 


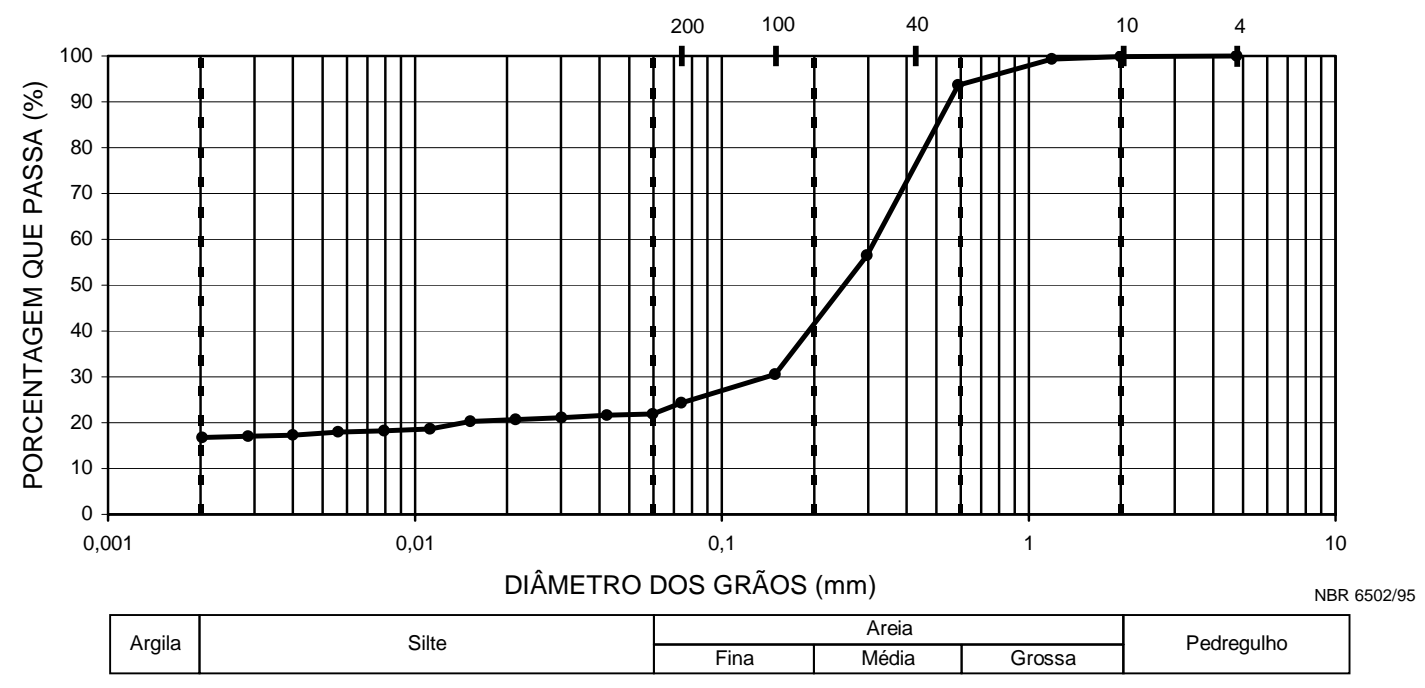

Figura 4.7. Curva de distribuição granulométrica para a mistura.

Cada fração granulométrica, em porcentagem de ocorrência, para o solo Serra Geral, para o solo Botucatu e para a mistura estão apresentadas na Tabela 4.1.

Tabela 4.1. Distribuição granulométrica em porcentagem de ocorrência para os três solos estudados, obtidos experimentalmente.

\begin{tabular}{cccc}
\hline $\begin{array}{c}\text { Fração } \\
\text { Granulométrica }\end{array}$ & $\begin{array}{c}\text { Serra } \\
\text { Geral }\end{array}$ & Botucatu & Mistura \\
\hline Argila (\%) & 51,2 & 8,6 & 16,8 \\
Silte (\%) & 18,8 & 2,5 & 5,2 \\
Areia (\%) & 30,0 & 88,9 & 78,0 \\
\hline
\end{tabular}

Para verificar se as frações granulométricas, obtidas a partir da curva de distribuição granulométrica se apresentavam de acordo com a proporção pré-definida (20\% Serra Geral e $80 \%$ Botucatu), foram calculados os valores teóricos para cada fração granulométrica da mistura. Para tal, realizou-se uma média ponderada entre os resultados obtidos para os solos Serra Geral e Botucatu (Tabela 4.1) e a proporção utilizada nesta pesquisa. Os valores teóricos calculados, bem como, a variação porcentual em relação ao valor determinado experimentalmente, encontra-se na Tabela 4.2. 
Tabela 4.2. Valores teóricos para cada fração granulométrica da mistura a partir dos resultados de granulometria conjunta dos solos Serra Geral e Botucatu.

\begin{tabular}{ccc}
\hline $\begin{array}{c}\text { Fração } \\
\text { Granulométrica }\end{array}$ & Teórico & $\begin{array}{c}\text { Variação } \\
\text { porcentual }\end{array}$ \\
\hline Argila (\%) & 17,1 & $+0,3$ \\
Silte (\%) & 5,8 & $+0,6$ \\
Areia (\%) & 77,1 & $-0,9$ \\
\hline
\end{tabular}

Ao analisar os valores mostrados na Tabela 4.2, verificaram-se pequenas variações entre os resultados experimentais e os teóricos obtidos para a mistura. Estas variações podem ser atribuídas a erros inerentes ao ensaio, porém, encontram-se dentro de uma faixa aceitável.

\subsubsection{Massa Específica dos Sólidos ( $\left.\rho_{s}\right)$}

A massa específica dos sólidos $\left(\rho_{s}\right)$ foi determinada de acordo com as sugestões da ASTM - D 854 e os procedimentos descritos por Nogueira (1995). Foram realizados três ensaios para cada solo. Os valores médios encontram-se na Tabela 4.3.

Tabela 4.3. Resultados médios da massa específica dos sólidos para os três solos.

\begin{tabular}{cc}
\hline Solo & $\boldsymbol{\rho}_{\text {s médio }}\left(\mathbf{g} / \mathbf{c m}^{\mathbf{3}}\right)$ \\
\hline Serra Geral & 2,838 \\
Botucatu & 2,649 \\
Mistura & 2,707 \\
\hline
\end{tabular}

\subsubsection{Ensaio de Compactação}

O objetivo deste ensaio foi determinar os parâmetros de compactação, umidade ótima $\left(w_{o t}\right)$ e massa específica seca máxima $\left(\rho_{\text {dmáx }}\right)$, para os solos estudados. À partir destes parâmetros, foi realizada a compactação dos corpos de prova a serem utilizados nos ensaios de percolação em coluna.

O ensaio de compactação foi realizado de acordo com os procedimentos descritos pela norma ABNT MB-33 (NBR-7182/84). Utilizou-se a energia de compactação Proctor Normal por unidade de volume $\left(583 \mathrm{KJ} / \mathrm{m}^{3}\right)$. 
As Figuras 4.8, 4.9 e 4.10 mostram as curvas de compactação obtidas para os solos Serra Geral, Botucatu e mistura, respectivamente.

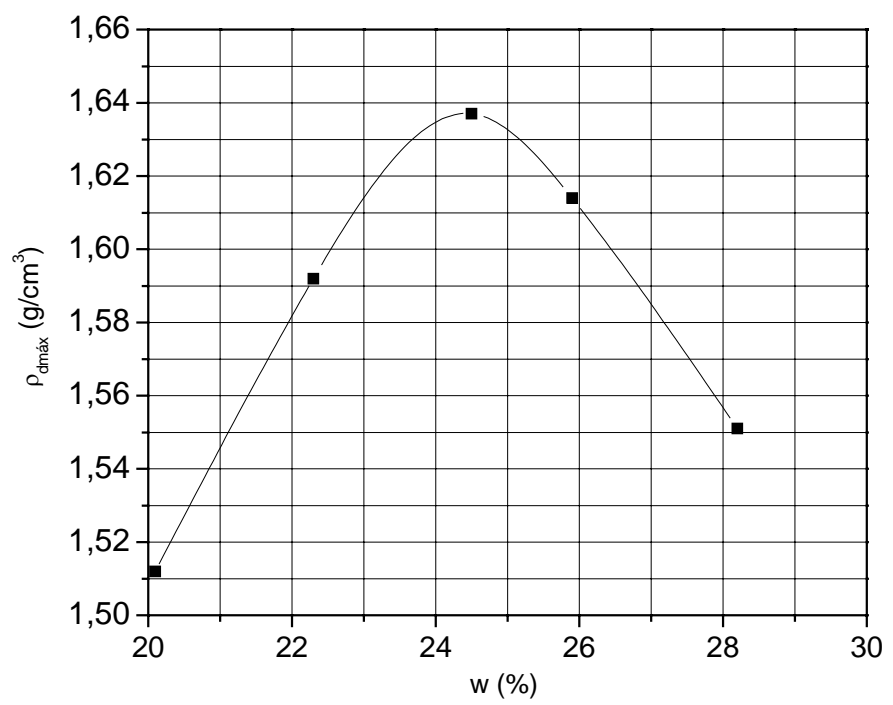

Figura 4.8. Curva de compactação Proctor Normal para o solo Serra Geral.

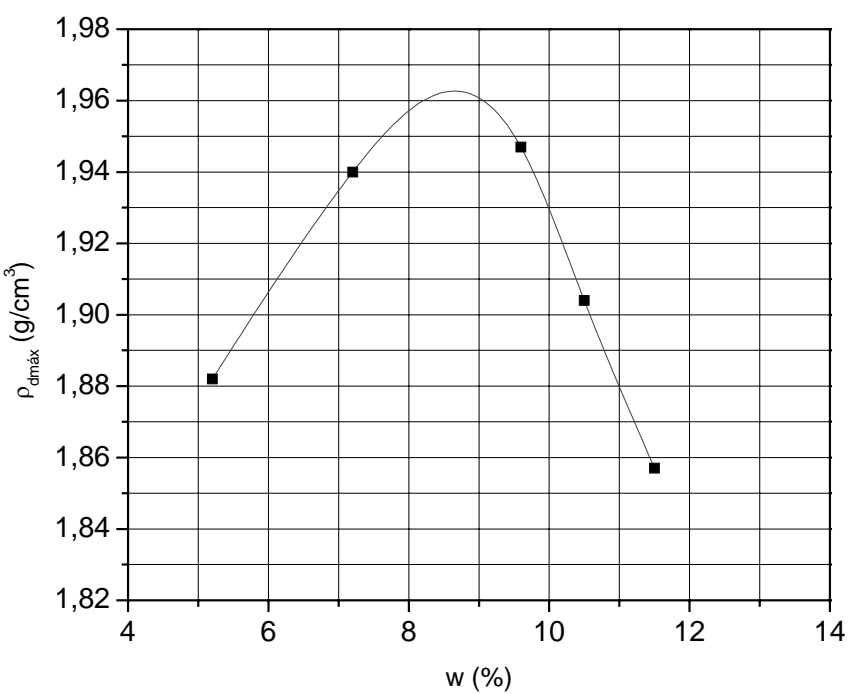

Figura 4.9. Curva de compactação Proctor Normal para o solo Botucatu. 


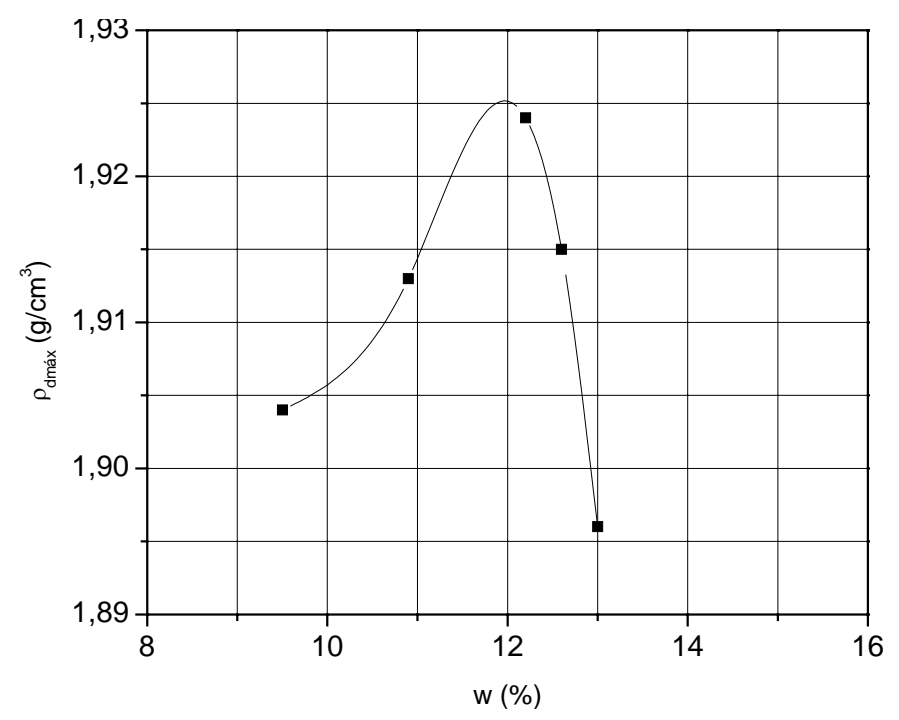

Figura 4.10. Curva de compactação Proctor Normal para a mistura.

A Tabela 4.4 mostra os parâmetros de compactação determinados a partir do ensaio de compactação para energia Proctor Normal.

Tabela 4.4. Parâmetros de compactação para energia Proctor Normal.

\begin{tabular}{ccc}
\hline Solo & $\boldsymbol{\rho}_{\text {dmáx }}\left(\mathbf{g} / \mathbf{c m}^{\mathbf{3}}\right)$ & $\mathbf{w}_{\text {ot }} \mathbf{( \% )}$ \\
\hline Serra Geral & 1,637 & 24,4 \\
Botucatu & 1,963 & 8,7 \\
Mistura & 1,925 & 12,0 \\
\hline
\end{tabular}

\subsubsection{Limites de Consistência}

Os ensaios de limite de liquidez e limite de plasticidade foram realizados de acordo com os procedimentos descritos nas normas ABNT-MB 30 (NBR-6459) e ABNT MB 31 (NBR-9180), respectivamente, e recomendações de Nogueira (1995). O ensaio de limite de liquidez foi realizado com o Aparelho de Casagrande. Para o solo Botucatu não foi possível determinar o limite de liquidez e o limite de plasticidade foi considerado não plástico.

O índice de atividade (IA) de Skempton considera as distintas propriedades mineralógicas e químico-coloidais de solos argilosos. Considerando-se as distintas 
características que os minerais argilas podem apresentar, pequenas quantidades de argilas muito ativas podem produzir um comportamento mais típico de solos argilosos do que maiores quantidades de outras argilas menos ativas. Este parâmetro, determinado por Skempton, foi verificado através da equação (VARGAS, 1977):

$$
I A=\frac{I_{p}(\%)}{(\%<2 \mu m)}
$$

A argila presente num solo é considerada normal quando seu $I A$ se situa entre 0,75 e 1,25. Quando IA é menor do que 0,75, a argila é inativa, e quando maior do que 1,25, a argila é considerada ativa, pois pequena quantidade de argila leva a um elevado índice de plasticidade (SOUSA PINTO, 1998).

As Figuras 4.11, 4.12 apresentam as curvas de fluência para os solos Serra Geral e Botucatu, respectivamente. A Tabela 4.5 apresenta de forma resumida, os resultados obtidos para os três solos em relação ao limite de liquidez (LL), limite de plasticidade (LP), índice de plasticidade (IP) e índice de atividade de Skempton (IA).

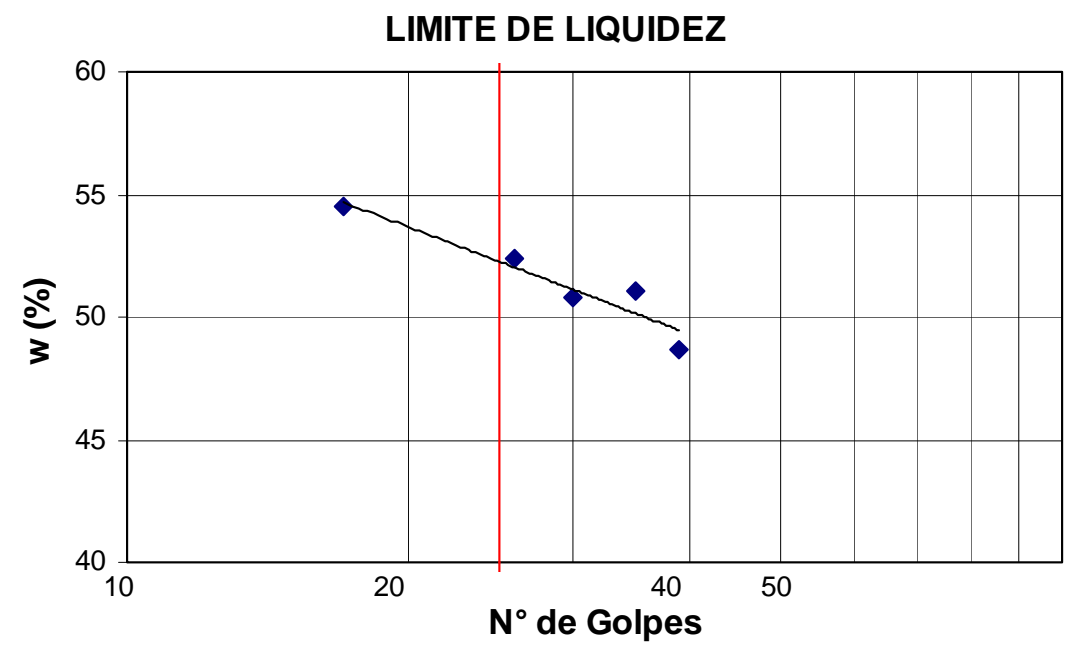

Figura 4.11. Curva de fluência para determinação do limite de liquidez para o solo Serra Geral. 


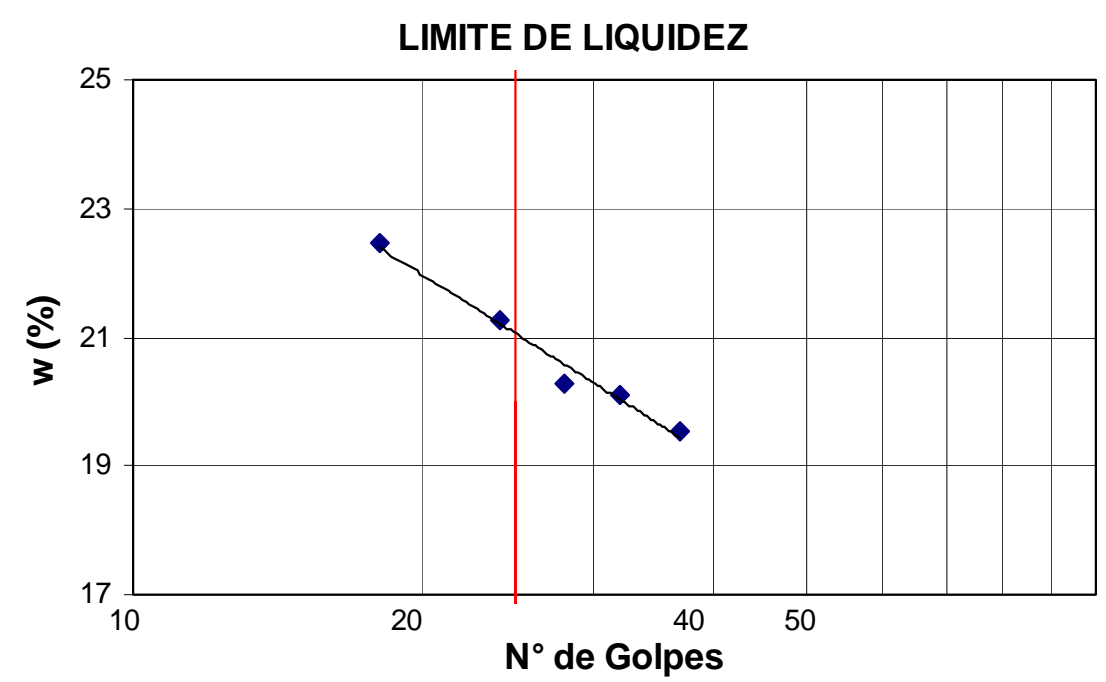

Figura 4.12. Curva de fluência para determinação do limite de liquidez para a Mistura.

Tabela 4.5. Resultados de limites de consistência e índice de atividade.

\begin{tabular}{ccccc}
\hline Solo & LL (\%) & $\mathbf{L P ( \% )}$ & $\mathbf{I P ( \% )}$ & IA \\
\hline Serra Geral & 49 & 32 & 17 & 0,33 \\
Botucatu & Não plástico & - & - \\
& & & \\
Mistura & 21 & 14 & 7 & 0,42 \\
\hline
\end{tabular}

\subsubsection{Caracterização Físico-Química dos Solos}

As propriedades físico-químicas, capacidade de troca de cátions (CTC) e a superfície específica (SE), foram determinadas por Basso (2003). A CTC representa a aptidão do argilomineral em trocar e reter íons positivos na sua superfície coloidal. A superfície específica relaciona-se a maior ou menor adsorção dos íons presentes na solução. Esta propriedade está relacionada à dimensão da área exposta na sua superfície. Para a determinação destes parâmetros foi utilizado o método de adsorção de Azul de Metileno, conforme metodologia descrita por Pejon (1992).

A determinação do pH em água foi realizada por Basso (2003), de acordo com o procedimento de Camargo et al. (1986). As propriedades físico-químicas estão apresentadas na Tabela 4.6. 
Tabela 4.6. Propriedades físico-químicas dos solos estudados.

\begin{tabular}{ccccc}
\hline Propriedade & Serra Geral & \multicolumn{2}{c}{ Botucatu } \\
\hline $\begin{array}{c}\text { Solo passado na } \\
\text { peneira }\end{array}$ & $\# 10$ & $\# 200$ & $\# 10$ & $\# 200$ \\
\hline $\begin{array}{c}\text { Capacidade de } \\
\text { Troca de Cátions } \\
\text { (CTC) (meq/100g) }\end{array}$ & 3,4 & 4,4 & 0,7 & 3,3 \\
$\begin{array}{c}\text { Superfície } \\
\text { Específica (SE) } \\
\left(\mathrm{m}^{2} / 100 \mathrm{~g}\right)\end{array}$ & 25,9 & 34,7 & 5,7 & 26,1 \\
\hline $\mathrm{pH}$ do solo $\left(\mathrm{H}_{2} \mathrm{O}\right)$ & \multicolumn{2}{c}{6,08} & \multicolumn{2}{c}{4,78} \\
\hline
\end{tabular}

\subsubsection{Caracterização Mineralógica dos Solos}

A caracterização mineralógica dos solos estudados foi realizada por Basso (2003) em amostras de solo com fração menor que $0,037 \mathrm{~mm}$ (passada na peneira \#400) e secas em estufa a $60^{\circ} \mathrm{C}$. Os métodos utilizados para descrição e análise foram: Análise Térmica Diferencial (ATD), Análise Térmica Gravimétrica (ATG) e Difratometria de Raios-X. A composição mineralógica está apresentada na Tabela 4.7.

Tabela 4.7. Composição mineralógica dos solos.

\begin{tabular}{ccc}
\hline Propriedade & Serra Geral & Botucatu \\
\hline Composição & Caulinita,Gibsita, & Caulinita, Gibsita e \\
Mineralógica & Goethita e Hematita & Quartzo \\
& & \\
\hline
\end{tabular}

\subsubsection{Comentários com Relação à Caracterização dos Solos}

Os resultados dos ensaios de caracterização geotécnica, juntamente com os resultados mineralógicos e físico-quimicos, determinados por Basso (2003), permitiram conhecer as propriedades dos solos estudados. Estes resultados serviram como base para poder iniciar os ensaio de percolação em colunas e ensaios triaxiais.

As distribuições granulométricas obtidas para os solos Serra Geral e Botucatu apresentaram-se bem próximos àquelas obtidas por Basso (2003), daí a justificativa para a realização de apenas um ensaio de granulometria conjunta para cada um dos solos. 
O procedimento utilizado na preparação da mistura mostrou-se eficaz, pois as frações granulométricas da mistura, obtidas experimentalmente, apresentaram-se próximas aos valores teóricos, o que garantiu uma maior consistência aos valores obtidos. De acordo com a análise granulométrica conjunta, a mistura é constituída de $22 \%$ de material fino (fração silte e argila). O índice de plasticidade foi de 7\%, que segundo Rowe et al. (1995) é uma das exigências técnicas requeridas para a sua utilização como barreira impermeável. $\mathrm{O}$ índice de atividade de Skempton indicou pouca atividade da fração fina ( menor que $2 \mu \mathrm{m}$ ), e seu resultado caracterizou a atividade das argilas presentes como inativas.

As massas específicas dos sólidos dos solos Serra Geral e Botucatu estão de acordo com a mineralogia dos solos. Os resultados da mineralogia mostraram que os argilominerais presentes na fração fina dos solos Serra Geral e Botucatu são do tipo 1:1 correspondendo ao grupo da caulinita e gibsita (óxidos e hidróxidos de Fe e Al).

Os valores de CTC e SE indicaram materiais com baixa retenção catiônica se comparados com os solos de clima temperado, enquanto que o resultado do $\mathrm{pH}$ do solo imerso em $\mathrm{H}_{2} \mathrm{O}$ caracterizou os solos como levemente ácidos, sendo que os mais ácidos correspondem ao solo Botucatu ( $\mathrm{pH}$ aproximadamente igual a 4,8).

A classificação dos solos Serra Geral, Botucatu e mistura segundo o Sistema Unificado de Classificação dos Solos (SUCS), está apresentada na Tabela 4.8.

Tabela 4.8. Classificação dos solos pelo sistema unificado (SUCS).

\begin{tabular}{ccc}
\hline Solo & Classificação - SUCS & Descrição \\
\hline Serra Geral & CL & $\begin{array}{c}\text { Argila Inorgânica de } \\
\text { baixa plasticidade }\end{array}$ \\
Botucatu & SC & Areia Argilosa \\
Mistura & SC & Areia Argilosa \\
\hline
\end{tabular}

\subsection{ENSAIO DE PERCOLAÇÃO EM COLUNAS DE SOLOS}

\subsubsection{Equipamento de Percolação}

O equipamento utilizado para a realização dos ensaios de percolação em colunas com água destilada e deionizada e com a solução contaminante, foi projetado e construído no Departamento de Geotecnia - USP (Leite et al.,1998). O equipamento utilizado consiste em um sistema de percolação, no qual a fonte de pressão se dá por injeção de ar comprimido em 
câmaras infláveis existentes no interior dos reservatórios. Este sistema apresenta a vantagem de poder realizar vários ensaios ao mesmo tempo, com colunas alimentadas por diferentes contaminantes e sob a mesma pressão. A Figura 4.13 apresenta o equipamento de percolação utilizado nesta pesquisa.
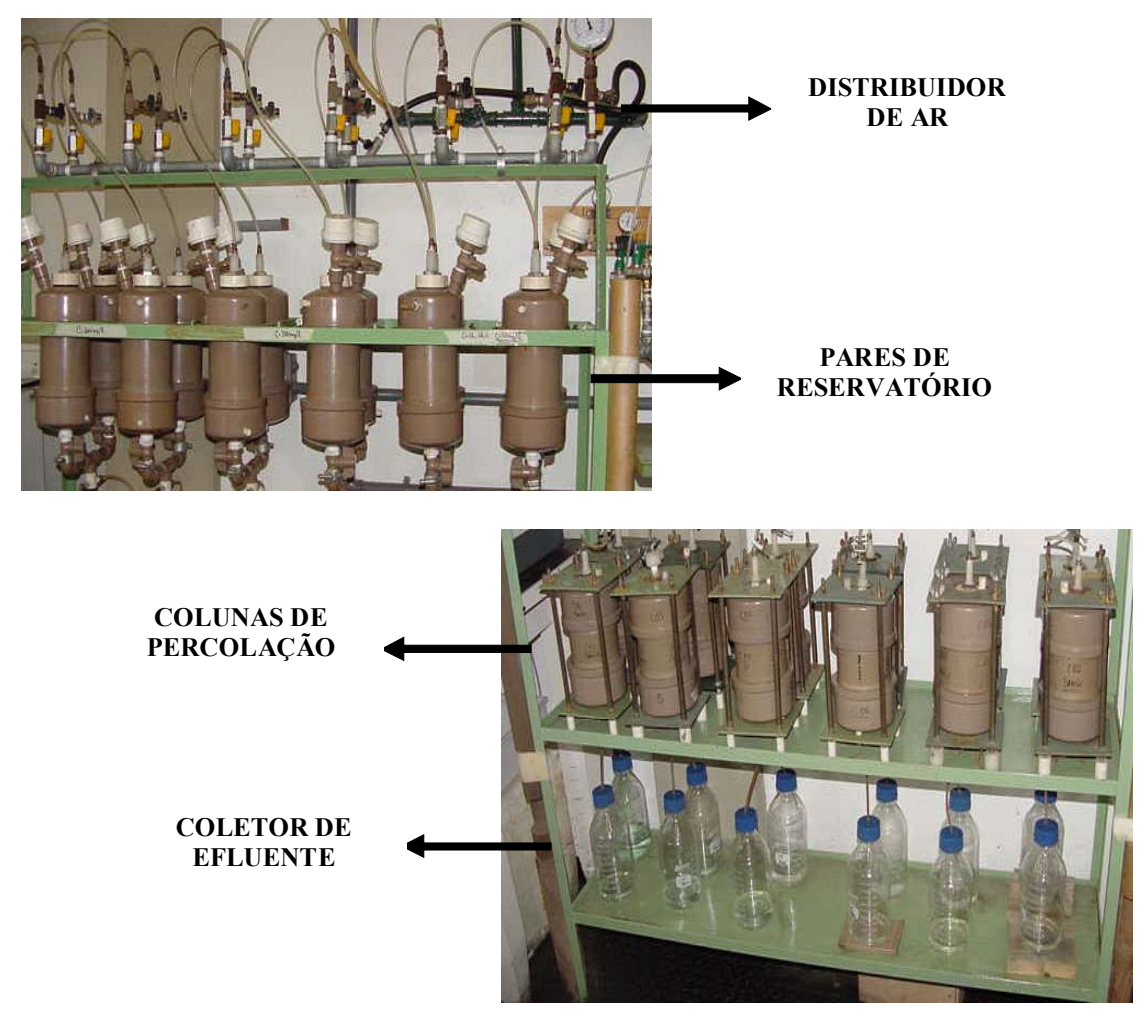

Figura 4.13. Equipamento utilizado para a realização dos ensaios de percolação em colunas.

O equipamento de percolação em colunas, conforme apresentado na Figura 4.13 é constituído pelos seguintes elementos:

- Distribuidor de ar comprimido: têm a finalidade de pressurizar todos os reservatórios com ar comprimido, mantendo-se constante o gradiente hidráulico;

- Reservatórios: são constituídos de tubos de PVC para alta pressão com 250 $\mathrm{mm}$ de altura, 92,8 $\mathrm{mm}$ de diâmetro externo e $0,35 \mathrm{~mm}$ de espessura de parede. Apresentam capacidade volumétrica de aproximadamente $1600 \mathrm{ml}$. No seu interior existe uma câmara inflável (membrana flexível) que serve como interface de pressão entre o ar comprimido e o líquido armazenado. A membrana apresenta as seguintes dimensões: $320 \mathrm{~mm}$ de comprimento, 190 $\mathrm{mm}$ de largura e $0,3 \mathrm{~mm}$ de espessura. 
- Colunas de percolação: compostas por células de percolação, placas de PVC pefuradas e caps superior e inferior. As células de percolação são segmentos de tubo de PVC para alta pressão que alojam os corpos de prova compactados com altura (H) de $150 \mathrm{~mm}$ e diâmetro (D) de $100 \mathrm{~mm}$. As placas perfuradas de PVC são colocadas no topo e na base do corpo de prova na forma de "sanduíche", ou seja, duas placas de PVC com uma malha de nylon de 400 mesh entre elas. Este sistema promove uma melhor distribuição da pressão hidráulica, além de evitar o carreamento de partículas finas durante a percolação. Os caps superior e inferior apresentam orifícios que tem a finalidade de promover o contato entre a solução e o corpo de prova e permitir a saída do liquido percolado.

- Coletor de efluente: é composto por um frasco de vidro graduado que apresenta volume de $1000 \mathrm{~cm}^{3}$ e por uma tampa rosqueada que apresenta um orifício para permitir que as mangueiras de borracha de silicone sejam conectadas e que a solução contaminante seja percolada.

\subsubsection{Procedimento de Ensaio}

O ensaio de percolação em coluna assemelha-se ao ensaio de condutividade hidráulica a carga constante. O procedimento do ensaio pode ser melhor apresentado pela Figura 4.14.

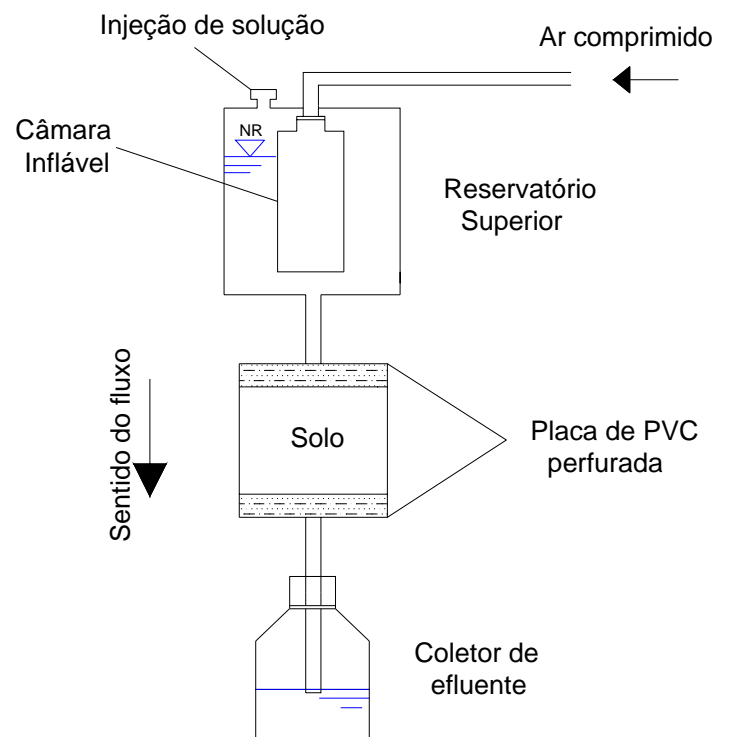

Figura 4.14. Procedimento de ensaio de percolação em coluna de solo (DANIEL, 1993 - modificado). 
Um reservatório superior alimenta o sistema com a solução contaminante de concentração conhecida $\left(C_{0}\right)$, provocando um fluxo descendente com carga constante através da amostra de solo compactado. Utilizando-se um reservatório, instalado na parte inferior do equipamento, realiza-se a coleta do efluente para proceder a análise química quantitativa.

\subsubsection{Compactação dos Corpos de Prova}

Os corpos de prova foram compactados nas próprias colunas destinadas ao ensaio de percolação. A compactação foi realizada em cinco camadas utilizando-se um compactador dinâmico com energia Proctor normal $\left(583 \mathrm{~kJ} / \mathrm{m}^{3}\right)$, conforme apresentado na Figura 4.15.

Para os três solos em estudo, utilizaram-se os parâmetros de compactação ( $w_{o t} \mathrm{e}$ $\rho_{d m a ́ x}$ ), obtidas nos ensaios de compactação Proctor normal. Todas as amostras foram compactadas com grau de compactação próximo a $100 \%$.

Os procedimentos utilizados para a preparação e compactação das amostras foram:

- Separação das amostras em sacos plásticos com 2,6 kg de solo e posterior armazenamento em câmara úmida;

- Umedecimento homogêneo com o volume de água necessário para atingir a umidade ótima;

- Armazenamento em câmara úmida para completa homogeneização e manutenção do teor de umidade;

- Após 24 h, determinação do teor de umidade;

- Correção do teor de umidade (quando não atingida a umidade ótima).

Após a amostra estar devidamente preparada para ser compactada, determinou-se a massa de solo a ser compactada através da seguinte equação:

$$
M_{s}=\rho_{d} V_{c}\left(1+w_{c}\right) G C
$$

onde:

$M s=$ massa de solo a ser compactada $(\mathrm{g})$;

$\rho_{d}=$ massa específica seca $\left(\mathrm{g} / \mathrm{cm}^{3}\right)$;

$V_{c}=$ volume da coluna $\left(\mathrm{cm}^{3}\right)$;

$w_{c}=$ umidade de compactação $(\%)$;

$G C=$ grau de compactação (\%). 


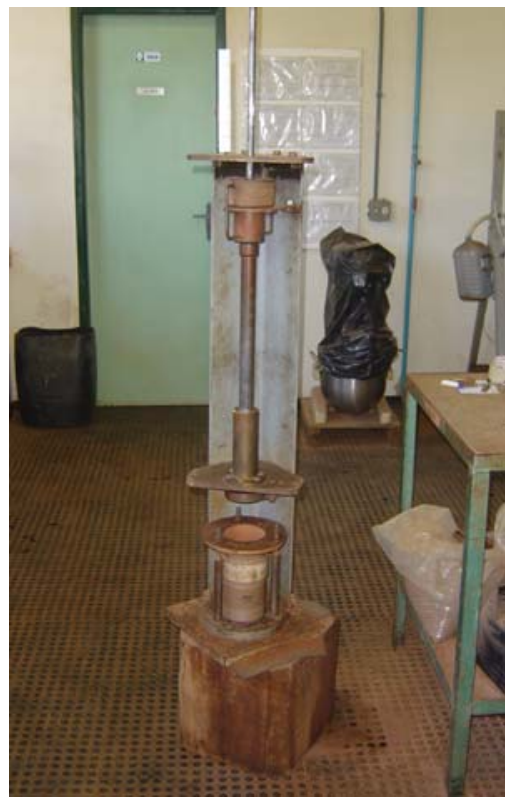

Figura 4.15. Compactador dinâmico.

Durante a etapa de compactação, os corpos de prova que não atingiram o grau de compactação estabelecido foram descartados. Nas Tabelas 4.9, 4.10 e 4.11, apresentam-se, respectivamente, os dados referentes à compactação de doze corpos de prova (colunas de solo compactado) para o solo Serra Geral, solo Botucatu e para a mistura. A quantidade apresentada está relacionada ao número de corpos de prova aproveitados para a realização do ensaio triaxial. 
Tabela 4.9. Dados referentes à compactação das amostras de solo Serra Geral.

\begin{tabular}{|c|c|c|c|c|c|c|c|c|c|c|c|c|}
\hline \multirow{3}{*}{$\begin{array}{l}\text { Dados de } \\
\text { compactação }\end{array}$} & \multicolumn{3}{|c|}{$\mathrm{C}=0 \mathrm{mg} / \mathrm{L}$} & \multicolumn{3}{|c|}{$C=50 \mathrm{mg} / \mathrm{L}$} & \multicolumn{3}{|c|}{$C=300 \mathrm{mg} / \mathrm{L}$} & \multicolumn{3}{|c|}{$\mathrm{C}=600 \mathrm{mg} / \mathrm{L}$} \\
\hline & \multicolumn{3}{|c|}{ Colunas } & \multicolumn{3}{|c|}{ Colunas } & \multicolumn{3}{|c|}{ Colunas } & \multicolumn{3}{|c|}{ Colunas } \\
\hline & 1 & 2 & 3 & 4 & & 6 & 7 & 8 & 9 & 10 & 11 & 12 \\
\hline thu &, 50 & 47 & 4,45 & 4,44 & 14,46 & 14,44 & 14,47 & 14,40 & 14,54 & 14,49 & 14,47 & 14,55 \\
\hline iân &, 7 & 9,74 & 9,72 & 9,72 & & 9 & 9,72 & & 9,72 & ,72 & & 9,7 \\
\hline Área & 3,9 & 74,5 & 74,2 & 74,2 & 2 & 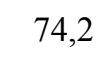 & 4,2 & 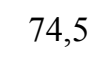 & 74,2 & 4,2 & 4,0 & 73,9 \\
\hline Volume $(\mathrm{cm}$ & 071 & 1078 & 1072 & 1071 & 1073 & 71 & 1074 & 1073 & 1079 & 1075 & 1071 & 1075 \\
\hline $\mathrm{M}_{\text {coluna }}(\mathrm{g})$ & 33,4 & 383,7 & 387,1 & 372,8 & 3 & $3 / 1$ & 392,6 & 84 & 388,4 & 374,4 & 86 & 380,2 \\
\hline $\mathrm{M}_{\text {solo }}$ & 66 & 2586 & 2578 & 2560 & & 9 & 92 & 79 & 2595 & 74 & 69 & 2574 \\
\hline $\mathrm{M}_{\text {solo }}$ & 83 & 2202 & 2191 & 2187 & 2203 & 21 & 2199 & 2195 & 2207 & 2200 & 83 & 2194 \\
\hline & 7 & & & 24 & & 2 & & & 24,7 & 4,7 & & 17 \\
\hline $\mathrm{w}_{\mathrm{c}}(\mathrm{O}$ & 4,9 & 25,2 & 25,1 & 25,2 & 25,4 & 25 & 25,4 & 5,0 & 25,2 & 25,0 & 25,0 & 25,1 \\
\hline $0_{0}(\mathrm{~g}$ & ,838 & 2,838 & 2,838 & 2,838 & 2,838 & 2,838 & 2,838 & 2,838 & 2,838 & 2,838 & 2,838 & 2,838 \\
\hline 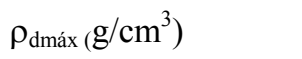 & 638 & 638 & 638 & 1,638 & 1,638 & 1,638 & 1,638 & 1,638 & 1,638 & 1,638 & 1,638 & 1,638 \\
\hline náx & 1, גו & 1,631 & 1,634 & 1,631 & 1,637 & 1,636 & 1,633 & 6 & 4 & 7 & 0 & 1,631 \\
\hline G &, 6 & 99,6 & 99,7 & 99,5 & 99,9 & 9 & 99,7 & ,9 & 99,7 & 99,9 & 99,5 & 99,6 \\
\hline & & & & & & & & & 0,74 & 0,73 & & 074 \\
\hline Poro & 42,5 & 42,5 & 42,4 & 42,5 & 42,3 & 42,4 & 42,4 & 42,3 & 42,4 & 42,3 & 42,6 & 42,5 \\
\hline & 155,7 & 458,4 & 455,1 & 455,8 & 454,0 & 454,0 & 455,7 & 454,2 & 457,9 & 455,0 & 456,2 & 457,4 \\
\hline & 95,5 & 96,7 & 96,6 & 96,6 & 98 & 98 & 97,7 & 96,6 & 97,0 & 96,7 & 95,7 & 96,2 \\
\hline Gradiente hidráulico & 52,4 & 52,5 & 52,6 & 52,6 & 52,6 & 52,6 & 52,5 & 52,8 & 52,3 & 52,4 & 52,5 & 52,2 \\
\hline
\end{tabular}

Tabela 4.10. Dados referentes à compactação das amostras de solo Botucatu.

\begin{tabular}{|c|c|c|c|c|c|c|c|c|c|c|c|c|}
\hline \multirow{3}{*}{$\begin{array}{l}\text { Dados de } \\
\text { compactação }\end{array}$} & \multicolumn{3}{|c|}{$C=0 \mathrm{mg} / \mathrm{L}$} & \multicolumn{3}{|c|}{$C=50 \mathrm{mg} / \mathrm{L}$} & \multicolumn{3}{|c|}{$\mathrm{C}=300 \mathrm{mg} / \mathrm{L}$} & \multicolumn{3}{|c|}{$\mathrm{C}=600 \mathrm{mg} / \mathrm{L}$} \\
\hline & \multicolumn{3}{|c|}{ Colunas } & \multicolumn{3}{|c|}{ Colunas } & \multicolumn{3}{|c|}{ Colunas } & \multicolumn{3}{|c|}{ Colunas } \\
\hline & 1 & 2 & 3 & 4 & 5 & 6 & 7 & 8 & 9 & 10 & 11 & 12 \\
\hline Altura (cm) & 14,64 & 15,00 & 15,00 & 14,98 & 14,98 & 14,99 & 14,98 & 14,98 & 15,00 & 15,00 & 15,00 & 15,00 \\
\hline Diâmetro (cm) & 9,71 & 9,69 & 9,7 & 9,7 & 9,7 & 9,7 & 9,69 & 9,7 & 9,7 & 9,7 & 9,7 & 9,7 \\
\hline Área $\left(\mathrm{cm}^{2}\right)$ & 74,0 & 73,7 & 73,9 & 73,9 & 73,9 & 73,9 & 73,7 & 73,9 & 73,9 & 73,9 & 73,9 & 73,9 \\
\hline Volume $\left(\mathrm{cm}^{3}\right)$ & 1084 & 1106 & 1108 & 1107 & 1107 & 1108 & 1105 & 1107 & 1108 & 1108 & 1108 & 1108 \\
\hline $\mathrm{M}_{\text {coluna }}(\mathrm{g})$ & 381,3 & 413,1 & 409,5 & 413 & 408,7 & 416,8 & 413,5 & 416,7 & 407,37 & 409,5 & 409,5 & 409,5 \\
\hline $\mathrm{M}_{\text {solo }}+\mathrm{M}_{\text {coluna }}(\mathrm{g})$ & 2686 & 2770 & 2756 & 2765 & 2756 & 2761 & 2765 & 2774 & 2774 & 2786 & 2763 & 2763 \\
\hline $\mathrm{M}_{\text {solo }}(\mathrm{g})$ & 2304 & 2357 & 2346 & 2352 & 2348 & 2344 & 2352 & 2358 & 2366 & 2376 & 2353 & 2354 \\
\hline Umidade ótima (\%) & 8,7 & 8,7 & 8,7 & 8,7 & 8,7 & 8,7 & 8,7 & 8,7 & 8,7 & 8,7 & 8,7 & 8,7 \\
\hline $\mathrm{w}_{\mathrm{c}}(\%)$ & 8,8 & 8,6 & 8,4 & 8,7 & 8,5 & 8,4 & 8,5 & 8,5 & 8,7 & 8,3 & 8,4 & 8,5 \\
\hline$\rho_{\mathrm{s}}\left(\mathrm{g} / \mathrm{cm}^{3}\right)$ & 2,648 & 2,648 & 2,648 & 2,648 & 2,648 & 2,648 & 2,648 & 2,648 & 2,648 & 2,648 & 2,648 & 2,648 \\
\hline$\rho_{\text {dmáx }\left(g / \mathrm{cm}^{3}\right)}$ & 1,963 & 1,963 & 1,963 & 1,963 & 1,963 & 1,963 & 1,963 & 1,963 & 1,963 & 1,963 & 1,963 & 1,963 \\
\hline $\begin{array}{l}\rho_{\text {dmáx }} \text { compactação } \\
\left(\mathrm{g} / \mathrm{cm}^{3}\right)\end{array}$ & 1,954 & 1,962 & 1,953 & 1,955 & 1,955 & 1,952 & 1,962 & 1,963 & 1,964 & 1,979 & 1,958 & 1,957 \\
\hline GC (\%) & 99,5 & 100,0 & 99,5 & 99,6 & 99,6 & 99,5 & 99,9 & 100,0 & 100,1 & 100,8 & 99,8 & 99,7 \\
\hline Índice de vazios (e) & 0,36 & 0,35 & 0,36 & 0,35 & 0,35 & 0,36 & 0,35 & 0,35 & 0,35 & 0,34 & 0,35 & 0,35 \\
\hline Porosidade (n) & 26,2 & 25,9 & 26,3 & 26,2 & 26,2 & 26,3 & 25,9 & 25,9 & 25,8 & 25,3 & 26,0 & 26,1 \\
\hline $\mathrm{Vv}\left(\mathrm{cm}^{3}\right)$ & 284,2 & 286,5 & 291,0 & 289,8 & 289,9 & 291,0 & 286,2 & 286,4 & 286,3 & 279,9 & 288,7 & 289,3 \\
\hline $\operatorname{Sr}(\%)$ & 65,6 & 65,2 & 62,5 & 65,0 & 63,4 & 62,4 & 64,4 & 64,5 & 66,2 & 65,1 & 63,2 & 63,7 \\
\hline Gradiente hidráulico & 15,7 & 15,3 & 15,3 & 15,4 & 15,4 & 15,3 & 15,4 & 15,4 & 15,3 & 15,3 & 15,3 & 15,3 \\
\hline
\end{tabular}


Tabela 4.11. Dados referentes à compactação das amostras da mistura.

\begin{tabular}{|c|c|c|c|c|c|c|c|c|c|c|c|c|}
\hline \multirow{3}{*}{$\begin{array}{l}\text { Dados de } \\
\text { compactação }\end{array}$} & \multicolumn{3}{|c|}{$C=0 \mathrm{mg} / \mathrm{L}$} & \multicolumn{3}{|c|}{$C=50 \mathrm{mg} / \mathrm{L}$} & \multicolumn{3}{|c|}{$C=300 \mathrm{mg} / \mathrm{L}$} & \multicolumn{3}{|c|}{$C=600 \mathrm{mg} / \mathrm{L}$} \\
\hline & \multicolumn{3}{|c|}{ Colunas } & \multicolumn{3}{|c|}{ Colunas } & \multicolumn{3}{|c|}{ Colunas } & \multicolumn{3}{|c|}{ Colunas } \\
\hline & 1 & 2 & 3 & 4 & 5 & 6 & 7 & 8 & 9 & 10 & 11 & 12 \\
\hline Altura (cm) & 14,92 & 15 & 14,97 & 14,97 & 14,97 & 14,94 & 14,97 & 14,55 & 14,97 & 15 & 14,5 & 14,64 \\
\hline Diâmetro (cm) & 9,64 & 9,68 & 9,7 & 9,68 & 9,68 & 9,7 & 9,72 & 9,74 & 9,7 & 9,7 & 9,71 & 9,71 \\
\hline Área $\left(\mathrm{cm}^{2}\right)$ & 73,0 & 73,6 & 73,9 & 73,6 & 73,6 & 73,9 & 74,2 & 74,5 & 73,9 & 73,9 & 74,0 & 74,0 \\
\hline Volume $\left(\mathrm{cm}^{3}\right)$ & 1089 & 1104 & 1106 & 1102 & 1102 & 1104 & 1111 & 1084 & 1106 & 1108 & 1074 & 1084 \\
\hline $\mathrm{M}_{\text {coluna }}(\mathrm{g})$ & 419,8 & 418,5 & 430,1 & 422,2 & 425,9 & 423,5 & 419,52 & 391,11 & 405,7 & 412,5 & 390 & 381,3 \\
\hline $\mathrm{M}_{\text {solo }}+\mathrm{M}_{\text {coluna }}(\mathrm{g})$ & 2768 & 2804 & 2820 & 2795 & 2812 & 2806 & 2809 & 2725 & 2792 & 2814 & 2718 & 2723 \\
\hline $\mathrm{M}_{\text {solo }}(\mathrm{g})$ & 2348 & 2385 & 2389 & 2373 & 2386 & 2383 & 2389 & 2334 & 2387 & 2402 & 2328 & 2341 \\
\hline Umidade ótima (\%) & 11,9 & 11,9 & 11,9 & 11,9 & 11,9 & 11,9 & 11,9 & 11,9 & 11,9 & 11,9 & 11,9 & 11,9 \\
\hline $\mathrm{w}_{\mathrm{c}}(\%)$ & 12,1 & 12,4 & 12,2 & 11,8 & 12,5 & 12,3 & 11,6 & 11,8 & 12,1 & 12,4 & 12,5 & 12,2 \\
\hline$\rho_{\mathrm{s}}\left(\mathrm{g} / \mathrm{cm}^{3}\right)$ & 2,707 & 2,707 & 2,707 & 2,707 & 2,707 & 2,707 & 2,707 & 2,707 & 2,707 & 2,707 & 2,707 & 2,707 \\
\hline$\rho_{\text {dmáx }}\left(\mathrm{g} / \mathrm{cm}^{3}\right)$ & 1,925 & 1,925 & 1,925 & 1,925 & 1,925 & 1,925 & 1,925 & 1,925 & 1,925 & 1,925 & 1,925 & 1,925 \\
\hline $\begin{array}{l}\rho_{\text {dmáx }} \text { compactação } \\
\left(\mathrm{g} / \mathrm{cm}^{3}\right)\end{array}$ & 1,923 & 1 & 5 & 27 & 25 & 2 & 1,927 & 1, & 25 & 28 & 1,927 & 1,925 \\
\hline GC (\%) & 99,9 & 99,9 & 100,0 & 100,1 & 100,0 & 99,8 & 100,1 & 100,0 & 100,0 & 100,1 & 100,1 & 100,0 \\
\hline Índice de vazios (e) & 0,41 & 0,41 & 0,41 & 0,40 & 0,41 & 0,41 & 0,40 & 0,41 & 0,41 & 0,40 & 0,40 & 0,41 \\
\hline Porosidade (n) & 28,9 & 29,0 & 28,9 & 28,8 & 28,9 & 29,0 & 28,8 & 28,9 & 28,9 & 28,8 & 28,8 & 28,9 \\
\hline $\mathrm{Vv}\left(\mathrm{cm}^{3}\right)$ & 315,2 & 320,0 & 319,5 & 317,5 & 318,1 & 320,2 & 320,0 & 312,9 & 319,7 & 319,2 & 309,2 & 313,2 \\
\hline $\operatorname{Sr}(\%)$ & 80,4 & 82,2 & 81,3 & 78,9 & 83,3 & 81,5 & 77,6 & 78,7 & 80,6 & 83,0 & 83,7 & 81,3 \\
\hline Gradiente hidráulico & 20,9 & 20,0 & 20,0 & 20,0 & 20,0 & 20,1 & 20,0 & 20,6 & 20,0 & 20,0 & 20,7 & 20,5 \\
\hline
\end{tabular}

\subsubsection{Preparação das Soluções Contaminantes}

As soluções contaminantes de cloreto de cobre $\left(\mathrm{CuCl}_{2} \cdot 2 \mathrm{H}_{2} \mathrm{O}\right)$ foram preparadas no Laboratório de Geotecnia Ambiental do Departamento de Geotecnia, em três diferentes concentrações em relação aos íons cobre: $50 \mathrm{mg} / \mathrm{L}, 300 \mathrm{mg} / \mathrm{L}$ e $600 \mathrm{mg} / \mathrm{L}$. Conhecendo-se a massa molecular do soluto $(170,5 \mathrm{~g})$ e a massa atômica do $C u^{+2}$ de $63,5 \mathrm{~g}$, foi possível, por meio de cálculos estequiométricos, calcular a quantidade necessária do cloreto de cobre para a preparação das soluções contaminantes nas diferentes concentrações iônicas de $\mathrm{Cu}^{+2}$.

Para a obtenção destas soluções, utilizou-se uma balança com precisão de décimos de miligrama, para a determinação da massa do soluto, e um balão volumétrico com capacidade volumétrica de $2000 \mathrm{ml}$, devidamente calibrado, para medir o volume de solvente (água destilada e deionizada). As soluções foram preparadas em volumes de 20 litros e armazenadas em galões devidamente limpos e identificados, permanecendo em ambiente com temperatura controlada $\left(20^{\circ} \mathrm{C}\right)$. As massas de cloreto de cobre utilizadas para a preparação de 20 litros da solução, nas diferentes concentrações, estão sintetizadas na Tabela 4.12. 
Tabela 4.12. Massa de cloreto de cobre utilizado na preparação das soluções.

\begin{tabular}{cc}
\hline $\begin{array}{c}\mathbf{C u}^{+2} \\
(\mathbf{m g} / \mathbf{L})\end{array}$ & $\begin{array}{c}\text { Massa(g) } \mathbf{C u C l}_{\mathbf{2}} \cdot \mathbf{2} \mathbf{H}_{\mathbf{2}} \mathrm{O} / \\
\mathbf{2 0} \text { litros de solução }\end{array}$ \\
\hline 50 & 2,68 \\
300 & 16,11 \\
600 & 32,22 \\
\hline
\end{tabular}

Após a preparação das soluções, foram determinados os parâmetros físicoquímicos e foram realizadas análises químicas quantitativas para confirmar os valores das concentrações em estudo. A Tabela 4.13 apresenta os parâmetros físico-químicos das soluções contaminantes:

Tabela 4.13. Parâmetros físico-químicos das Soluções.

\begin{tabular}{ccccc}
\hline $\begin{array}{c}\mathbf{C u}^{+2} \\
(\mathbf{m g} / \mathbf{L})\end{array}$ & $\begin{array}{c}\mathbf{C l}^{-1} \\
(\mathbf{m g} / \mathbf{L})\end{array}$ & $\mathbf{p H}$ & $\begin{array}{c}\mathbf{E h} \\
(\mathbf{m V})\end{array}$ & $\begin{array}{c}\mathbf{C E} \\
(\mathbf{u S} / \mathbf{c m})\end{array}$ \\
\hline 50 & 55,9 & 5,59 & 525 & 209 \\
300 & 335,4 & 5,09 & 547 & 1164 \\
600 & 670,9 & 4,96 & 555 & 2135 \\
\hline
\end{tabular}

\subsubsection{Percolação com Água Destilada e Contaminante}

Os ensaios de percolação em colunas foram realizados com os três solos estudados. O tempo médio despendido nesta etapa para realizar a completa atenuação do contaminante pelo solo foi de aproximadamente oito meses, três meses e um mês, para os solos Serra Geral, mistura e Botucatu, respectivamente.

O número de colunas percoladas foi determinado de forma que sobrassem algumas colunas para eventuais substituições durante o programa de ensaios. Esta preocupação surgiu em virtude do tempo despendido para realizar a completa atenuação do contaminante pelo solo e da necessidade de se substituir os corpos de prova que viessem a ter problemas durante a realização do ensaio triaxial. Inicialmente realizou-se a percolação simultânea em dezesseis colunas de solo Serra Geral. Para cada concentração de contaminante utilizada $(0,50,300$ e $600 \mathrm{mg} / \mathrm{L})$ foram percoladas quatro colunas com pressão de $76 \mathrm{kPa}$, a mesma utilizada por Boff (1999), Leite (2000) e Basso (2003). Esta pressão é 
justificada por situar-se no intervalo entre 50 a $100 \mathrm{kPa}$, pressões estas representativas para as barreiras selantes de aterros sanitários.

Na seqüência realizou-se a percolação simultânea em vinte colunas da mistura, sendo cinco para cada concentração de contaminante $(0,50,300$ e $600 \mathrm{mg} / \mathrm{L})$. Devido a limitação do equipamento, foram percoladas mais oito colunas do solo Botucatu, sendo quatro para a concentração $0 \mathrm{mg} / \mathrm{L}$ e quatro para concentração $50 \mathrm{mg} / \mathrm{L}$. À medida em que se encerravam as percolações das colunas, foram colocadas mais colunas do solo Botucatu até completar as doze colunas restantes, ou seja, cinco para a concentração $300 \mathrm{mg} / \mathrm{L}$, cinco para a concentração $600 \mathrm{mg} / \mathrm{L}$, uma para a concentração 0 e uma para a concentração $50 \mathrm{mg} / \mathrm{L}$.

Em virtude da maior condutividade hidráulica do solo Botucatu e da mistura em relação ao solo Serra Geral, não foi possível manter para estes solos a mesma pressão que foi utilizada para o solo Serra Geral. Utilizou-se a pressão de $23 \mathrm{kPa}$ para o solo Botucatu e 30 $\mathrm{kPa}$ para a mistura.

O ensaio de percolação foi iniciado com a percolação de água destilada. Durante esta etapa os principais objetivos eram:

a) reduzir a concentração iônica pré-existente nos poros dos solos, com a lixiviação dos sais solúveis;

b) promover a saturação do corpo de prova, obtendo-se a condição de fluxo estacionário, com a condutividade hidráulica passando a permanecer constante.

Durante a percolação com água destilada monitoravam-se as amostras do efluente, quanto às condições físico-químicas ( $p H, E h$ e $C E$ ). Quando os valores de condutividade elétrica $(C E)$ se apresentavam próximos aos da água pura, consideravam-se que as amostras apresentavam-se isentas de sais, podendo então, iniciar a percolação com a solução contaminante.

No transcorrer da percolação com a solução contaminante, as amostras coletadas continuavam a ser monitoradas, conforme descrito anteriormente, mas também, passou-se a determinar o volume acumulado da solução percolada $(V p)$ e a concentração $(C)$ dos íons $\mathrm{Cu}^{+2}$ e $\mathrm{Cl}^{-1}$ existentes nas amostras, por meio de análises químicas quantitativas.

Durante estes ensaios também foram determinadas às condutividades hidráulicas dos solos. Os valores de condutividade hidráulica foram calculados a partir da equação de Darcy e referenciados à temperatura de $20^{\circ} \mathrm{C}$ para padronizar o efeito da viscosidade com a temperatura. 


\subsubsection{Determinação dos Parâmetros Físico-Químicos}

A quantificação dos parâmetros físico-químicos $(p H, E h$ e $C E)$ em amostras coletadas dos efluentes durante as etapas de saturação com água e contaminante é um indicativo importante para definir a estabilidade química das soluções percolantes (água ou solução contaminante) no solo.

O potencial de oxi-redução $(E h)$ foi determinado por um milivoltímetro, modelo B 374 e marca microNal. O potencial hidrogenionico $(p H)$ foi determinado por um pHmetro, modelo DM 21 e marca Digimed, enquanto que a condutividade elétrica $(C E)$ foi quantificada por um condutivímetro, modelo 650 e marca Analyser. Estes equipamentos estão mostradas nas Figuras 4.16, 4.17 e 4.18.

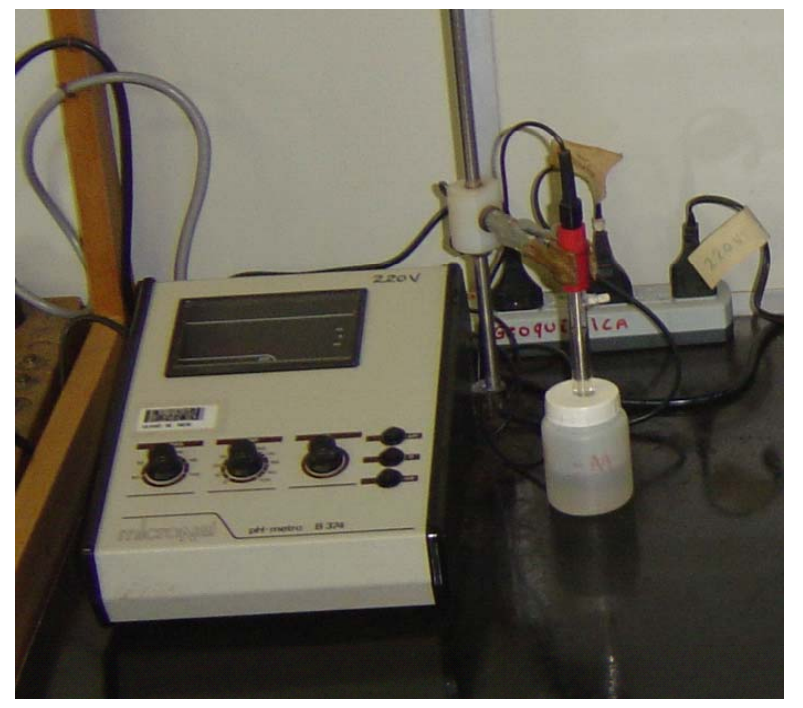

Figura 4.16.Milivoltímetro utilizado para a determinação do $E h$.

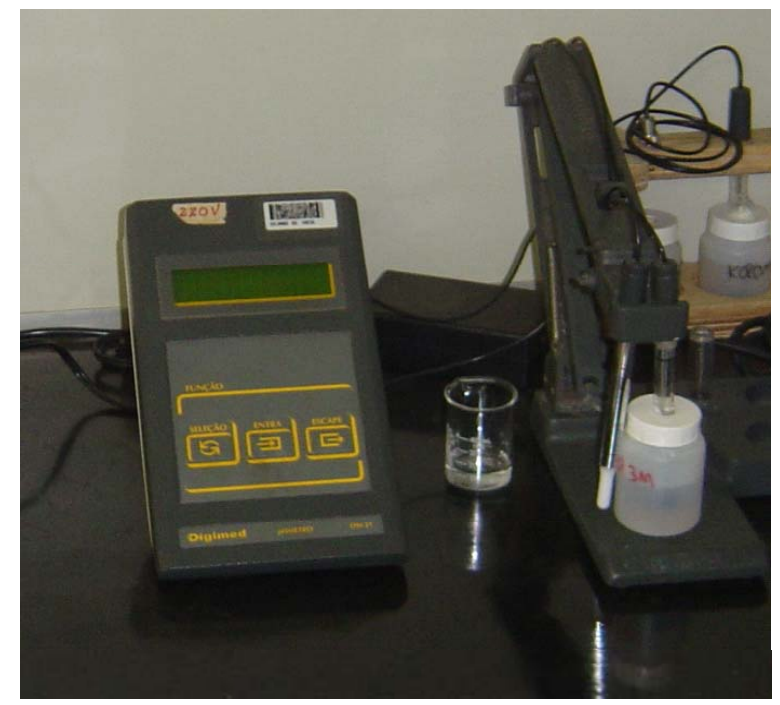

Figura 4.17. pHmetro utilizado para a determinação do $p H$. 


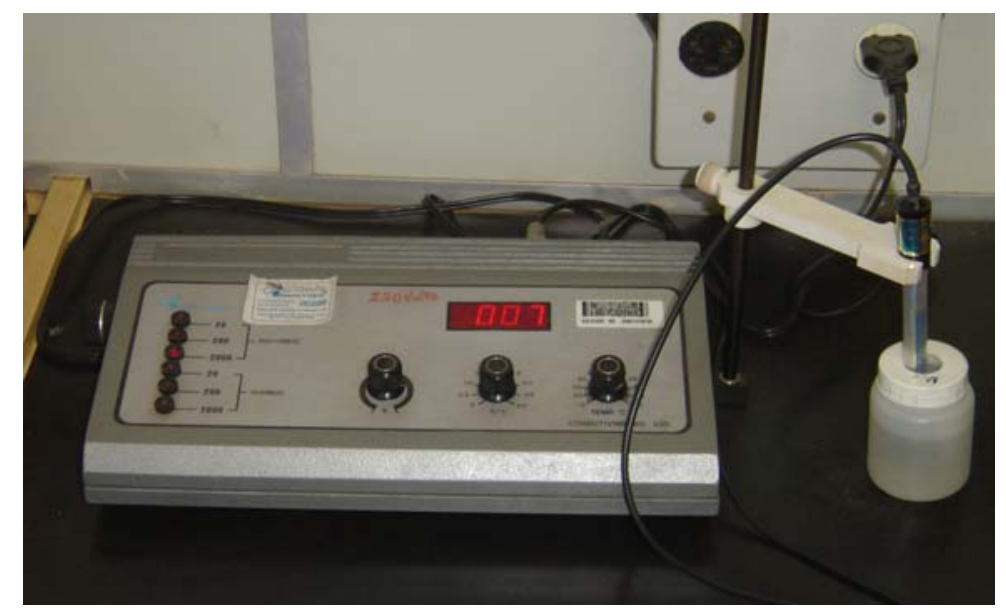

Figura 4.18. Condutivímetro utilizado para a determinação da condutividade elétrica.

As amostras submetidas à caracterização físico-quimica foram divididas em três lotes, uma amostra para cada determinação $(E h, p H$ e $C E)$. Assim, buscou-se eliminar erros provocados por eventuais interações químicas que pudessem ocorrer entre os eletrodos e a solução analisada.

\subsubsection{Análise Química Quantitativa}

A concentração de íons cobre na amostra foi determinada através de um espectrofotômetro visível, marca HACH e modelo DR/2010, com comprimento de onda de $560 \mathrm{~nm}$. Este equipamento determina com precisão as concentrações de $\mathrm{Cu}^{+2}$, dentro de uma faixa que varia de 0,0 a 5,0 mg/L. Para adequar as amostras à faixa do equipamento, realizouse a diluição das soluções amostradas.

Para realizar a diluição da solução de $50 \mathrm{mg} / \mathrm{L}$ utilizou-se uma pipeta graduada de $20,0 \mathrm{ml}$ da amostra de solução contaminante e balão volumétrico de $250 \mathrm{ml}$. Para a concentração de $300 \mathrm{mg} / \mathrm{L}$, utilizou-se uma pipeta graduada de 3,0 $\mathrm{ml}$ da amostra de solução contaminante e balão volumétrico de $250 \mathrm{ml}$ enquanto que para a solução de $600 \mathrm{mg} / \mathrm{L}$ uma pipeta graduada de $3,0 \mathrm{ml}$ da amostra de solução contaminante e balão volumétrico de $500 \mathrm{ml}$.

O equipamento inicialmente foi zerado com uma solução em branco, composta por 10,0 $\mathrm{ml}$ de água destilada e um reagente em pó que identifica a presença de íons cobre. Em seguida adicionou-se este reagente a uma amostra de efluente. A reação com os íons cobre existentes na amostra provocou mudança na coloração da solução para roxa/rósea, ficando com cores mais intensificadas para maiores concentrações de íons cobre. Após um 
período de ensaio de dois minutos, o equipamento determinou a concentração de cobre na solução.

A presença de íons Cloreto $\left(\mathrm{Cl}^{-1}\right)$ na amostra, foi quantificada através do Método Argentométrico $(4500-\mathrm{Cl})$, descrito por Alpha Standard Methods (1995). Este método consiste na titulação da amostra utilizando o nitrato de prata $\mathrm{AgNO}_{3}$. A titulação ocorre sobre um agitador magnético, para facilitar as reações químicas. Inicialmente, adiciona-se à amostra, condicionada em um erlenmeyer, aproximadamente $0,5 \mathrm{ml}$ de $\mathrm{NaOH}$ para aumentar o pH e facilitar as reações químicas e $1,0 \mathrm{ml}$ de Cromato de Potássio $\left(\mathrm{k}_{2} \mathrm{CrO}_{4}\right)$ como indicador, que torna a solução amarela. Ao adicionar o nitrato de prata à amostra, por meio de uma bureta graduada, ocorre a reação entre os íons cloreto e os íons prata, formando o cloreto de prata $\mathrm{AgCl}$. Ao término desta reação, inicia-se a reação entre o indicador e o nitrato de prata, formando o cromato de prata. A mudança da coloração da solução, tornando-se avermelhada, indica o final da análise. O cálculo da concentração de íons cloreto (mg/l) presentes na amostra, é realizado da seguinte forma:

$$
C l^{-}=\frac{35450\left(V_{a}-V_{b}\right) N}{V_{i}}
$$

onde:

$V_{a}=$ volume utilizado $(\mathrm{ml})$ na titulação da amostra;

$V_{b}=$ volume utilizado $(\mathrm{ml})$ na titulação do branco;

$N=$ normalidade do $\mathrm{AgNO}_{3}(\mathrm{~N})$;

$V_{i}=$ volume da amostra $(\mathrm{ml})$.

As Figuras 4.19 e 4.20 mostram os equipamentos utilizados para a determinação dos íons cobre e cloreto presentes na solução contaminante.

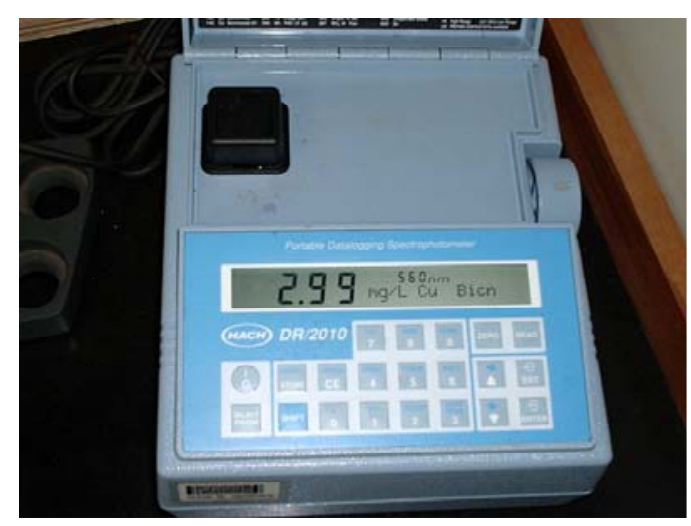

Figura 4.19. Espectrofotômetro visível HACH. 


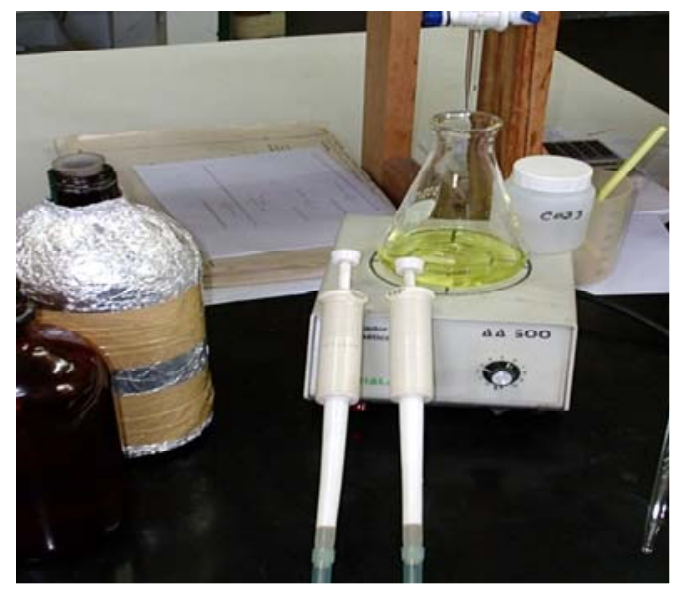

Figura 4.20. Detalhe da amostra no interior de um erlenmeyer e sobre um agitador magnético, durante sua titulação utilizando-se o nitrato de prata.

\subsection{ENSAIO TRIAXIAL}

\subsubsection{Considerações}

Dentre os modos como os ensaios triaxiais podem ser conduzidos, pode-se dizer que o ensaio consolidado - não drenado (CU) seria o que melhor se aplicaria às barreiras impermeáveis (liners). Este tipo de ensaio representa as situações em que, o maciço apresenta-se em equilíbrio com as tensões aplicadas e em seguida, ao ocorrer uma solicitação rápida, sem possibilidade de dissipação das novas pressões neutras geradas, dá-se a ruptura. Esta situação pode ser relacionada ao carregamento de um liner, onde durante o lançamento e conseqüente alteamento do aterro de resíduos dentro de uma célula de disposição, é permitida a dissipação das pressões neutras geradas. Ao se atingir uma altura ou solicitação crítica, gera-se uma tensão que promove a ruptura da barreira de forma instantânea.

\subsubsection{Preparação dos Corpos de Prova}

Ao término do ensaio de percolação em colunas, os corpos de prova foram extrudados das respectivas colunas. Os corpos de prova do solo Botucatu e da mistura foram retirados normalmente, através de um extrator de amostras (Figura 4.21). Entretanto, a alta aderência entre o solo Serra Geral e a coluna de PVC, não permitiu este procedimento. Foi necessário confinar a coluna compactada dentro de uma caixa metálica e cortá-la em quatro posições para facilitar a retirada das amostras. Esta caixa, apresentada na Figura 4.22, é 
constituída por paredes laterais e de fundo soldadas em uma base e por uma parede frontal móvel que permite, com o auxílio de um parafuso, ajustar a coluna no interior da caixa.

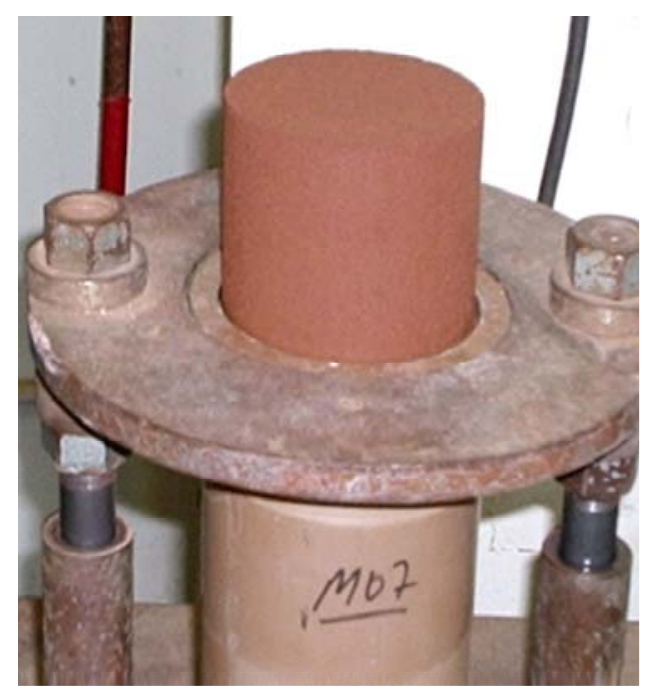

Figura 4.21. Retirada de amostras por meio de extrator.

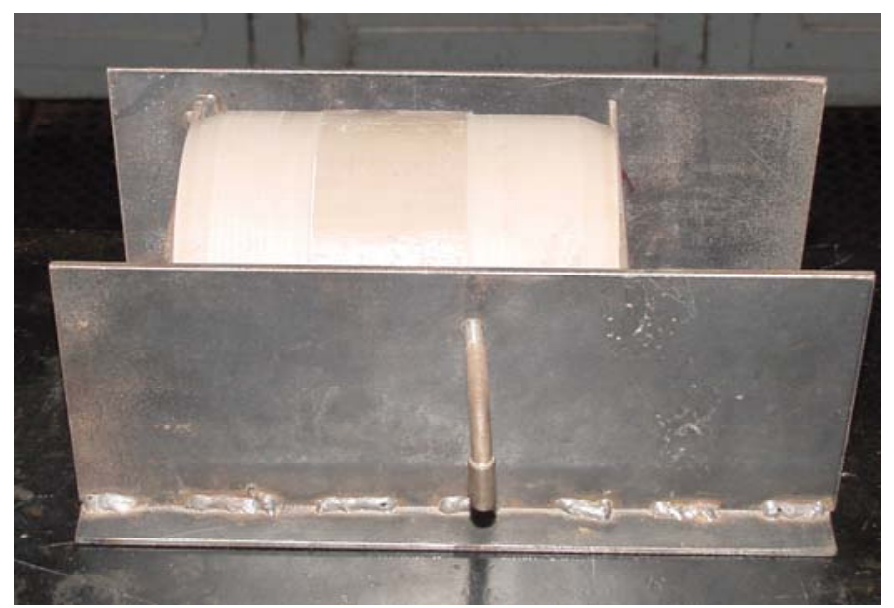

Figura 4.22. Detalhe da caixa metálica utilizada para a retirada do corpo de prova Serra Geral.

As dimensões iniciais dos corpos de prova $(100 \mathrm{~mm}$ x $150 \mathrm{~mm})$ não atendiam as relações entre altura e diâmetro $(\mathrm{H}=2,0$ a 2,5 D), conforme prescrito pela ASTM D 476795. Realizou-se, então, o processo de talhagem das amostras, transformando-as em corpos de prova com as seguintes dimensões: $\mathrm{D}=50 \pm 1 \mathrm{~mm} \mathrm{e} \mathrm{H}=125 \pm 2 \mathrm{~mm}$. O processo se iniciou com a colocação da amostra sobre um berço apropriado (Figura 4.23) para realizar a retirada do excesso de solo do topo e da base, tomando-se os devidos cuidados para deixá-las planas e paralelas. Posteriormente, a amostra foi levada a um torninho de talhagem e com o auxílio de uma faca retirou-se o excesso lateral de solo (Figura 4.24), deixando o corpo de prova com o diâmetro mencionado. 


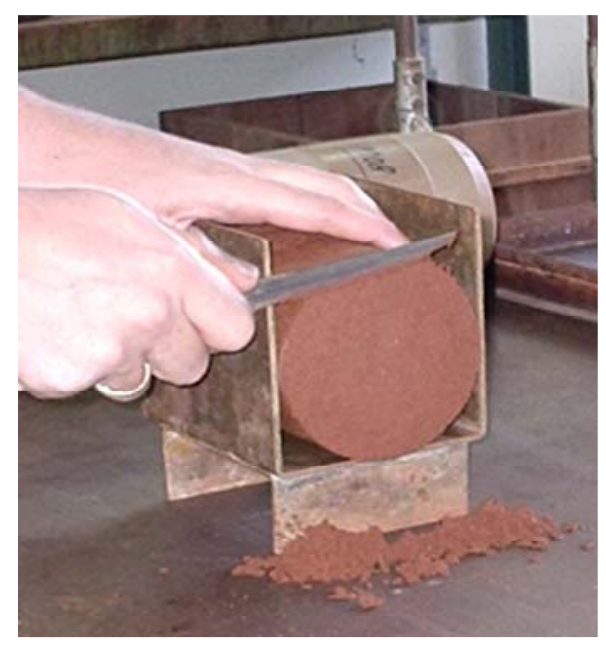

Figura 4.23. Processo de talhagem do topo e da base do corpo de prova.

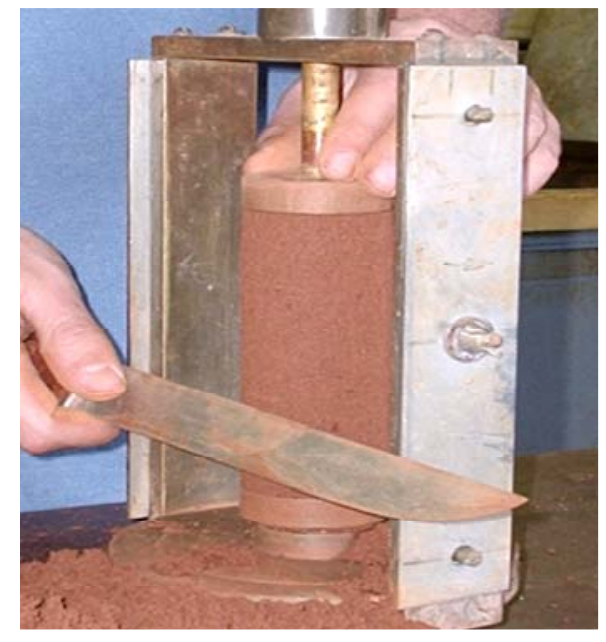

Figura 4.24. Talhagem lateral do corpo de prova.

Após o processo de talhagem, foram determinadas as dimensões do corpo de prova (diâmetro e altura), a sua massa e o teor de umidade. Para se evitar perdas de umidade até a realização dos ensaios, os corpos de prova foram envolvidos por filme de PVC e guardados em um dessecador, conforme mostrado na Figura 4.25. 


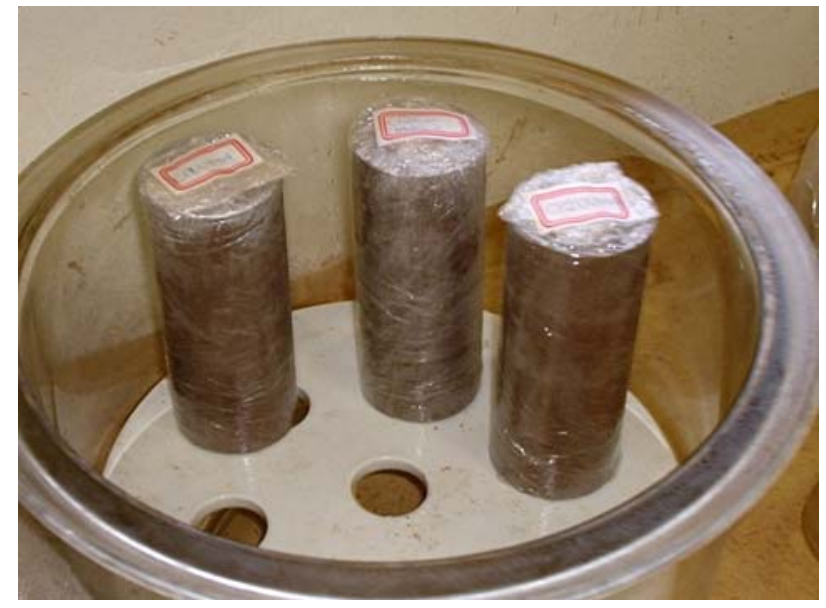

Figura 4.25. Corpos de prova condicionados no interior de um dessecador.

\subsubsection{Avaliações Preliminares}

Para avaliar, preliminarmente, se a interação entre o contaminante e os materiais do equipamento triaxial poderiam deteriorá-lo, realizou-se um teste. Para tal, amostras dos materiais existentes no equipamento triaxial, tais como latão, acrílico, látex e aço-inox, foram imersos dentro de um recipiente. Este recipiente foi preenchido com cloreto de cobre na concentração mais crítica $(600 \mathrm{mg} / \mathrm{L})$ e foi deixado durante o período de uma semana no interior de uma sala climatizada para se evitar qualquer alteração na concentração da solução por evaporação.

Após o período de avaliação, constatou-se que não ocorreu nenhum processo de deterioração dos materiais mencionados anteriormente.

\subsubsection{Equipamento Triaxial}

Os equipamentos utilizados nesta pesquisa, para a realização dos ensaios triaxiais, encontram-se disponíveis no Laboratório de Mecânica dos Solos. Todos os componentes utilizados na montagem e realização do ensaio estão listados a seguir:

- Prensa mecânica modelo Wykeham Farrance com capacidade de 100 kN, com velocidades utilizáveis entre 25 e $0,2 \mathrm{~mm} / \mathrm{min}$ para cargas abaixo de $50 \mathrm{kN}$ e inferiores de $0,2 \mathrm{~mm} / \mathrm{min}$ para cargas até $100 \mathrm{kN}$;

- Anel dinamométrico Wykeham Farrance com capacidade de 5 kN e 15 kN;

- Relógio comparador Wykeham Farrance de precisão 0.002 mm;

- Câmara para ensaio triaxial Wykeham Farrance resistente até 1,7 MPa;

- Trandutor de pressão Wykeham Farrance, modelo 17060 com capacidade de $1000 \mathrm{kPa}$;

- Transdutores de deslocamento LSC Transducer $50 \mathrm{~mm}$; 
- Transdutor LSC Transducer $25 \mathrm{~mm}$;

- Medidor de variação de volume Wykeham Farrance;

- Painel para controle de pressão;

- Sistema para aquisição de dados.

A Figura 4.26 apresenta o esquema de funcionamento do equipamento triaxial após a sua montagem. A Figura 4.27 apresenta o equipamento utilizado para realização dos ensaios triaxiais.

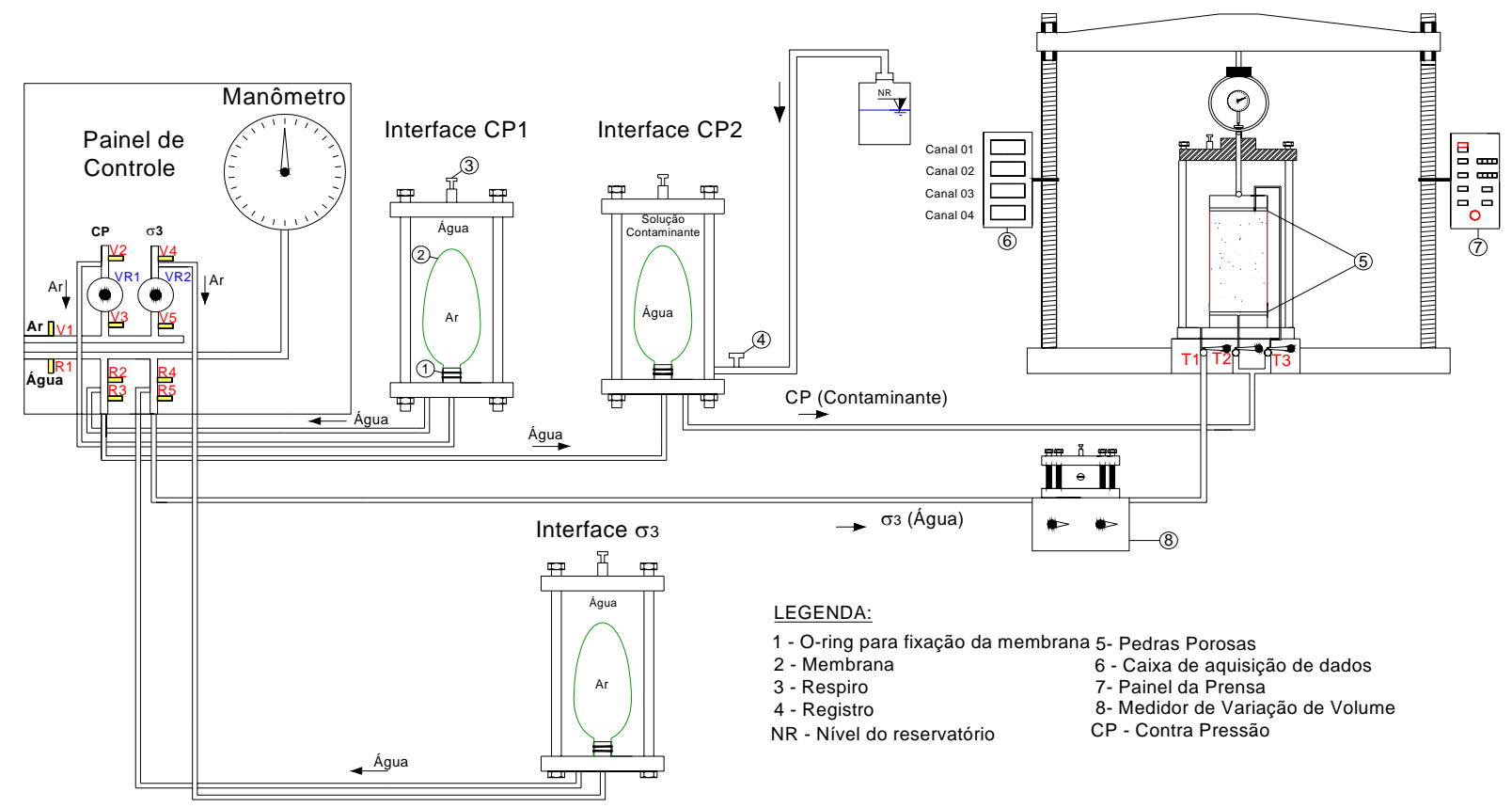

Figura 4.26. Esquema do equipamento utilizado para realizar os ensaios triaxiais.

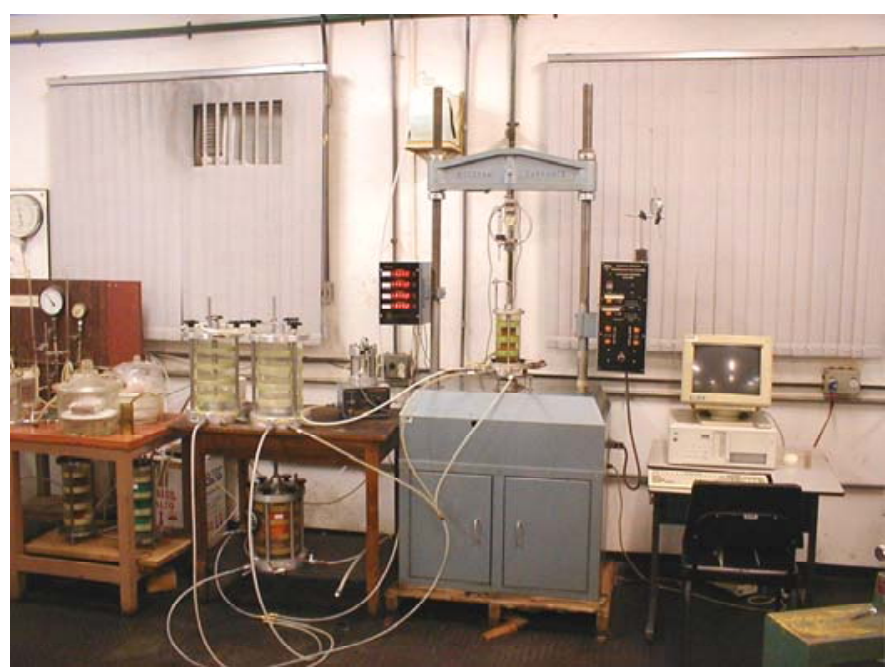

Figura 4.27. Equipamento para a realização dos ensaios triaxiais. 
- Aquisição de Dados - Calibração do Equipamento

O sistema de aquisição de dados do equipamento triaxial é composto por um aquisitor com quatro canais. $\mathrm{O}$ ensaio de compressão triaxial do tipo adensado-rápido envolve as seguintes leituras: força aplicada ao pistão (utilizando um anel dinamométrico), deformação do corpo de prova (obtidas com o auxilio de um transdutor de deslocamento), variação de volume do corpo de prova e leitura de pressões neutras (ensaios não drenados). Desta forma, para a realização dos ensaios desta pesquisa, os canais representavam as seguintes variáveis: força, variação de volume, pressão neutra e deslocamento.

Todos os instrumentos foram devidamente calibrados nos seus correspondentes canais, determinando-se as respectivas constantes de calibração (Tabela 4.14).

Tabela 4.14. Constantes dos canais do sistema de aquisição.

\begin{tabular}{cc}
\hline Variável & Constante \\
\hline Força & $0,3590 \mathrm{Kgf}$ \\
Variação de Volume & $0,02837 \mathrm{~cm}^{3}$ \\
Pressão Neutra & $0,1188 \mathrm{kPa}$ \\
Deslocamento & $0,01256 \mathrm{~mm}$ \\
\hline
\end{tabular}

\subsubsection{Procedimento de Ensaio}

- Montagem do Corpo de Prova na Câmara Triaxial

A seqüência da montagem do corpo de prova na câmara triaxial foi a seguinte:

- Imersão das pedras porosas em água e aquecimento para eliminação das bolhas de ar inclusas;

- Posicionamento do corpo de prova na base da câmara triaxial, estando o corpo de prova capeado no topo e base pela pedra porosa;

- Com o uso de um testador de membranas, realizou-se o controle de qualidade das membranas quanto ao aparecimento de furos;

- Encamisamento do corpo de prova com a membrana de látex, com o auxílio de um aplicador de membrana;

- Fixação da membrana de látex com orings (base) e elásticos de borracha (cap). 
- Aplicação de graxa de silicone no contato entre a membrana e o cap para vedar qualquer caminho preferencial de água para o interior do corpo de prova.

A Figura 4.28 mostra o corpo de prova após sua fixação na câmara triaxial.

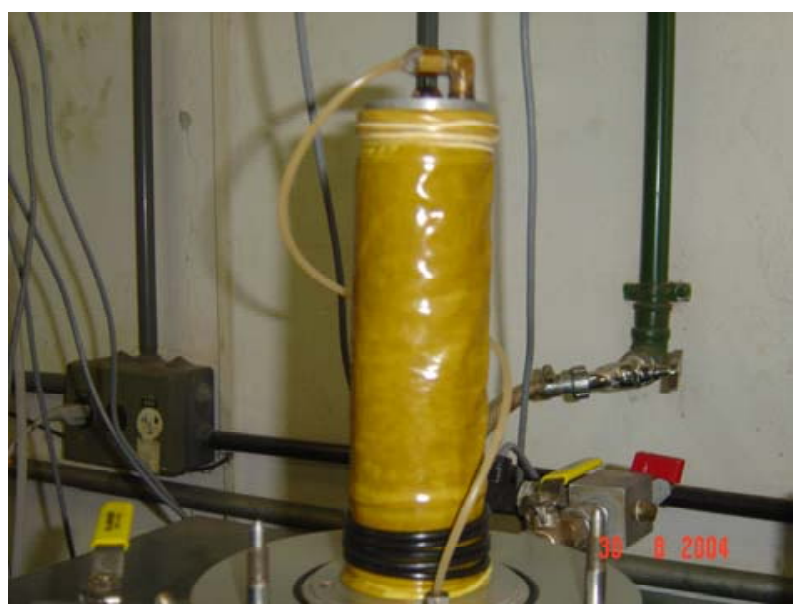

Figura 4.28. Corpo de prova após sua montagem para a realização do ensaio triaxial.

\section{- Fase de Saturação da Amostra}

A saturação do corpo de prova foi realizada por contra pressão, conforme procedimento descrito por Head (1986). Para tal, utilizaram-se duas interfaces de pressão para a aplicação da contra pressão e uma interface para a aplicação da pressão de confinamento $\left(\sigma_{3}\right)$.

O processo de saturação do corpo de prova pode ser melhor entendido por meio da Figura 4.26. Inicialmente, aplicou-se a pressão de confinamento $\left(\sigma_{3}\right)$. Para tal, abriu-se a válvula V1, liberando a entrada de ar comprimido na tubulação para, então, abrir a válvula V5 que dá acesso a válvula reguladora de ar VR2. A pressão de ar foi aplicada a uma membrana de látex existente no interior da interface $\sigma_{3}$ (ar-água). Esta pressão foi transmitida à água circundante, retornando ao painel de controle para a realização da leitura manométrica, com a abertura do registro R4. A aplicação desta pressão à câmara triaxial se deu através da abertura do registro R5 e torneira T1 conectado à base da câmara.

A aplicação da contra pressão foi realizada da mesma forma, mas, para se evitar o contato entre a solução contaminante e o manômetro, instalou-se uma segunda interface. A interface $\mathrm{CP} 1$ trabalha de forma idêntica à interface $\sigma_{3}$, porém, a água pressurizada, ao invés de ir diretamente para a câmara, ocupa o interior de uma membrana de látex existente na segunda interface CP2 (água-contaminante), transmitindo esta pressão à solução 
contaminante circundante (alimentada por um reservatório superior). Através de dois registros (T2 e T3) acoplados à base da câmara triaxial, a solução contaminante entra em contato com o solo pela base e pelo topo, respectivamente.

A fase de saturação durou 48 horas para o solo Serra Geral e 24 horas para o solo Botucatu e para a mistura. Os incrementos e períodos de manutenção das pressões de confinamento e contra pressão foram dimensionados de forma a otimizar a fase de saturação, sendo, portanto, distribuídos dentro destes períodos. Adotou-se como procedimento deixar o último estágio de saturação em um intervalo de tempo equivalente à metade do tempo despendido durante a saturação.

A máxima pressão disponível de ar comprimido no equipamento triaxial foi de $780 \mathrm{kPa}$. Para poder realizar o ensaio triaxial da mesma forma, tanto para a maior tensão de confinamento (200 kPa) quanto para as menores menores tensões confinantes (50 e $100 \mathrm{kPa})$, o último estágio de saturação foi definido com pressão de confinamento de $550 \mathrm{kPa}$ e contra pressão de $540 \mathrm{kPa}$. Assim, a tensão de confinamento no corpo de prova foi aplicada, aumentando-se a pressão de confinamento e mantendo-se constante a contra pressão, até atingir a tensão confinante de interesse (dada pela diferença entre a pressão de confinamento e a contra pressão). A título de exemplo, para a aplicação da tensão confinante de $200 \mathrm{kPa}$, aumentou-se a pressão de confinamento até $740 \mathrm{kPa}$ e manteve-se constante a contra pressão do último estágio $(540 \mathrm{kPa})$. Desta forma, foi possível atingir a máxima tensão de confinamento $(200 \mathrm{kPa})$, respeitando a pressão de ar comprimido disponível.

A distribuição dos estágios de pressão confinante e de contra pressão para a saturação do solo Serra Geral, do solo Botucatu e da mistura, está sintetizada a seguir pelas Tabelas 4.15, 4.16 e 4.17, respectivamente.

Tabela 4.15. Estágios de saturação para o solo Serra Geral.

\begin{tabular}{ccccc}
\hline Estágio & $\begin{array}{c}\text { Pressão } \\
\text { Confinante } \\
\text { (kPa) }\end{array}$ & $\begin{array}{c}\text { Contra } \\
\text { Pressão } \\
(\mathbf{k P a})\end{array}$ & $\begin{array}{c}\text { Duração } \\
\text { do Estágio } \\
\text { (h) }\end{array}$ & $\begin{array}{c}\text { Parâmetro } \\
\text { B }\end{array}$ \\
\hline 1 & 50 & 40 & 2 & - \\
2 & 100 & 90 & 2 & - \\
3 & 200 & 190 & 2 & - \\
4 & 300 & 290 & 2 & - \\
5 & 400 & 390 & 4 & - \\
6 & 500 & 490 & 12 & 0,92 \\
7 & 550 & 540 & 24 & 0,95 \\
\hline
\end{tabular}


Tabela 4.16. Estágios de saturação para o solo Botucatu.

\begin{tabular}{ccccc}
\hline Estágio & $\begin{array}{c}\text { Pressão } \\
\text { Confinante } \\
(\mathbf{k P a})\end{array}$ & $\begin{array}{c}\text { Contra } \\
\text { Pressão (kPa) }\end{array}$ & $\begin{array}{c}\text { Duração } \\
\text { do Estágio } \\
\text { (h) }\end{array}$ & $\begin{array}{c}\text { Parâmetro } \\
\mathbf{B}\end{array}$ \\
\hline 1 & 50 & 40 & 2 & - \\
2 & 100 & 90 & 2 & - \\
3 & 200 & 190 & 2 & - \\
4 & 300 & 290 & 2 & - \\
5 & 400 & 390 & 2 & - \\
6 & 500 & 490 & 2 & 0,89 \\
7 & 550 & 540 & 12 & 0,92 \\
\hline
\end{tabular}

Tabela 4.17. Estágios de saturação para a mistura.

\begin{tabular}{ccccc}
\hline Estágio & $\begin{array}{c}\text { Pressão } \\
\text { Confinante } \\
(\mathbf{k P a})\end{array}$ & $\begin{array}{c}\text { Contra } \\
\text { Pressão (kPa) }\end{array}$ & $\begin{array}{c}\text { Duração do } \\
\text { Estágio } \\
\text { (h) }\end{array}$ & $\begin{array}{c}\text { Parâmetro } \\
\text { B }\end{array}$ \\
\hline 1 & 50 & 40 & 2 & - \\
2 & 100 & 90 & 2 & - \\
3 & 200 & 190 & 2 & - \\
4 & 300 & 290 & 2 & - \\
5 & 400 & 390 & 2 & - \\
6 & 500 & 490 & 2 & 0,90 \\
7 & 550 & 540 & 12 & 0,93 \\
\hline
\end{tabular}

A leitura do parâmetro B foi realizada nos estágios 6 e 7. Para realizar a leitura do parâmetro $\mathrm{B}$, aplicou-se um incremento de pressão confinante $\left(\Delta \sigma_{3}\right)$ de $50 \mathrm{kPa}$, e mediu-se o acréscimo de pressão neutra $(\Delta \mathrm{u})$ gerado. $\mathrm{O}$ parâmetro $B$ de Skempton é expresso pela relação:

$$
B=\frac{\Delta u}{\Delta \sigma_{3}}
$$

Segundo Vilar (2002), para valores de $B$ superiores a 0,95, pode-se considerar que o corpo de prova está saturado. Em virtude da limitação da pressão de ar comprimido e da dificuldade de se atingir este valor, principalmente para solos com maiores porcentagens de areia, os valores máximos do parâmetro $B$ atingidos para os solo Serra Geral, para o solo Botucatu e para a mistura, foram, respectivamente, 0,95, 0,92 e 0,93.

- Fase de Adensamento e Cisalhamento das Amostras

Os ensaios triaxiais do tipo CU (adensado e não drenado) foram realizados de forma convencional, ou seja, com um único estágio de carregamento. Embora a técnica de ensaios em múltiplos estágios fosse a indicada para utilizar um menor número possível de corpos de prova, os resultados apresentados por Izzo (2003) mostraram que esta técnica 
afetou em demasia os valores de resistência. Foram realizados, para cada solo estudado, quatro séries de ensaios, variando as concentrações do contaminante $(0,50,300$ e $600 \mathrm{mg} / \mathrm{L})$. Dentro de cada série, foram ensaiados pelo menos três corpos de prova com diferentes tensões de confinamento.

As tensões de confinamento $(50,100$ e $200 \mathrm{kPa})$ foram adotadas considerando dados apresentados por Sharma e Lewis (1994), ou seja, considerando uma solicitação crítica no liner de $150 \mathrm{kPa}$, provocada pelo peso próprio de um resíduo de peso específico igual a 10 $\mathrm{kN} / \mathrm{m}^{3}$ e disposto em um aterro de altura média de $15,0 \mathrm{~m}$.

Antes de iniciar o adensamento, ajustou-se a tensão de confinamento (diferença entre a pressão de confinamento e a contra pressão) aplicada no corpo de prova, aumentando -se a pressão confinante e mantendo-se constante a contra pressão. Aplicou-se a tensão de confinamento com a abertura da torneira T1, mantendo-se fechadas as torneiras T2 e T3. O valor de variação de volume registrado em conseqüência da aplicação da pressão de confinamento e aumento volumétrico do sistema (câmara + mangueiras), serviu como valor de referência para a aquisição de dados da fase de adensamento. Iniciou-se o ensaio com a permissão da drenagem do corpo de prova, abrindo-se as torneiras T2 e T3. O tempo despendido nesta fase foi de aproximadamente duas horas para o solo Serra Geral e uma hora e meia para os outros solos.

Durante a fase de adensamento, a variação de volume do corpo de prova foi determinada por um medidor de variação de volume, instalado em série na tubulação de aplicação da pressão de confinamento $\sigma_{3}$ (Figura 4.26). Este equipamento registrou a variação de volume do corpo de prova, pelo volume de água que entrou ou saiu da câmara triaxial. Durante a drenagem do corpo de prova, por exemplo, um volume adicional de água entrou na câmara triaxial para compensar a diminuição de volume do corpo de prova e para manter a pressão de confinamento constante dentro da câmara triaxial. A Figura 4.29 mostra o equipamento utilizado para a determinação da variação de volume no ensaio triaxial. 


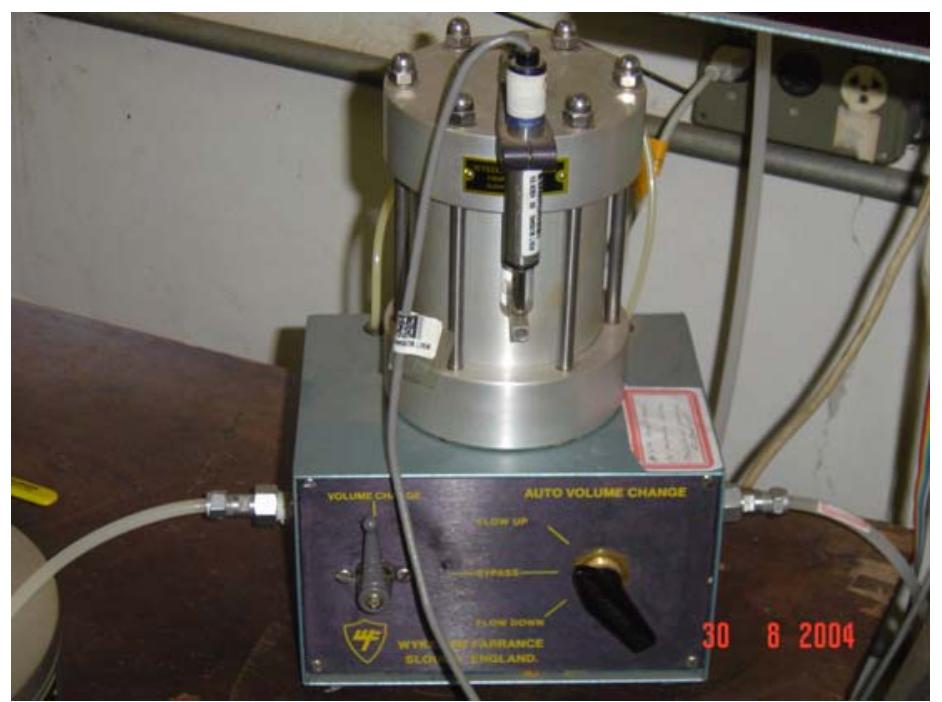

Figura 4.29. Equipamento utilizado para a medição da variação de volume.

Antes de iniciar a fase de cisalhamento das amostras, determinou-se a velocidade para realizar os incrementos da tensão desvio $\left(\sigma_{1}-\sigma_{3}\right)$, conforme o critério sugerido por Head (1986). A velocidade de carregamento deve ser tal que o excesso de pressão neutra gerado durante o ensaio CU seja estabilizado e registrado de forma mais representativa.

Inicialmente, estimou-se o tempo $t_{100}$ (tempo despendido para a ocorrência de $100 \%$ do adensamento), obtido a partir dos gráficos de adensamento (Variação volumétrica versus $\sqrt{ } t$ ), conforme procedimento apresentado na Figura 4.30.

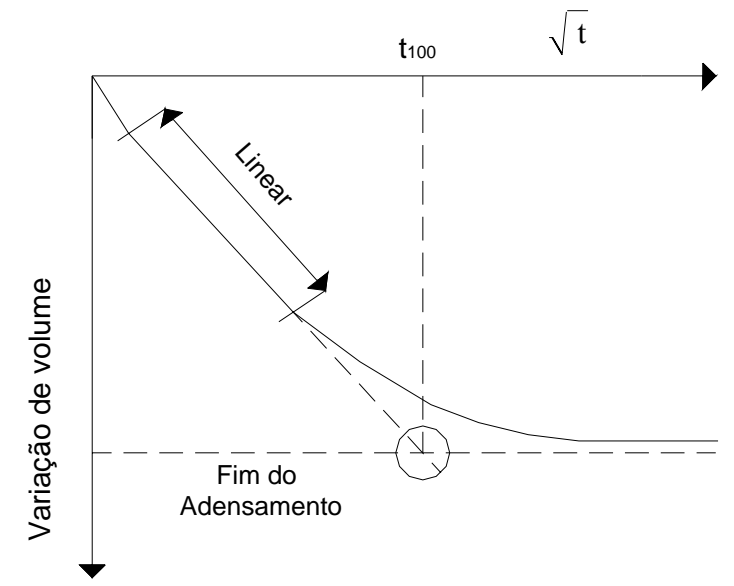

Figura 4.30. Determinação de $t_{100}$ a partir do gráfico de adensamento.

A partir do tempo despendido para a ocorrência de $100 \%$ do adensamento, estimou-se o tempo de ruptura do corpo de prova $\left(t_{f}\right)$, considerando o corpo de prova sem drenagem lateral, a partir da equação a seguir (HEAD, 1986): 


$$
t_{f}=0,51 \times t_{100}
$$

Desta forma, a velocidade máxima $\left(V_{\text {máx }}\right)$ a ser adotada no ensaio triaxial tipo CU foi estimada pela expressão:

$$
V_{\text {máx }}=\frac{\varepsilon_{f} L}{100 t_{f}}
$$

onde:

$\varepsilon_{f}=$ deformação do corpo de prova na ruptura $(\%)$;

$L=$ altura inicial do corpo de prova $(\mathrm{mm})$;

$t_{f}=$ tempo necessário para que a ruptura ocorra $(\min )$.

O valor de $t_{100}$ foi de aproximadamente 2 minutos para os três solos. Assim, o tempo de ruptura $\left(t_{f}\right)$ foi calculado em aproximadamente 1 minuto. A deformação na ruptura $\left(\varepsilon_{f}\right)$ foi estimada, em média, como sendo $5 \%$. Assim, a velocidade máxima com que os ensaios poderiam ser realizados seria de $6,25 \mathrm{~mm} / \mathrm{minuto}$. Entretanto, como esta velocidade é relativamente alta, preferiu-se adotar uma velocidade mais baixa e usual para este tipo de ensaio. A velocidade utilizada foi de $0,5 \mathrm{~mm} /$ minuto, já que esta velocidade se apresentou de forma eficaz em alguns ensaios-teste realizados preliminarmente.

\subsubsection{Correção da área do corpo de prova no Ensaio Triaxial}

Em um ensaio triaxial do tipo $\mathrm{CU}$, em que a drenagem do corpo de prova é impedida, o volume do corpo de prova permanece inalterado. Sendo assim, a diminuição da altura do corpo de prova (perda de volume em altura) corresponde a um aumento no diâmetro do corpo de prova, fenômeno este denominado de "barreling".

O aumento no diâmetro do corpo de prova provoca um aumento na área da sua seção transversal, que resulta no cálculo de uma tensão menor que a calculada a partir da área original. Neste sentido, para evitar erros de cálculo, pode-se proceder à correção da área, utilizando-se a seguinte expressão (Head, 1986):

$$
\left(\sigma_{1}-\sigma_{3}\right)=\frac{P\left(1-\varepsilon_{i}\right)}{A_{0}\left(1-\frac{\Delta V_{i}}{V_{0}}\right)}
$$


onde:

$\sigma_{1}-\sigma_{3}=$ tensão desviatória $(\mathrm{kPa})$;

$P=$ carga aplicada axialmente no corpo de prova $(\mathrm{kN})$;

$A_{0}=$ área inicial do corpo de prova $\left(\mathrm{m}^{2}\right)$;

$V_{0}=$ volume inicial do corpo de prova $\left(\mathrm{m}^{3}\right)$;

$\varepsilon_{i}=$ deformação axial do corpo de prova no instante $\mathrm{i}$;

$\Delta V_{i}=$ variação de volume do corpo de prova no instante $\mathrm{i}\left(\mathrm{m}^{3}\right)$.

A correção da área do corpo de prova, quando submetido a um carregamento axial, já se apresentou incorporada ao programa de aquisição de dados utilizado, permitindo assim que a correção fosse feita automaticamente durante a execução do ensaio triaxial. 
Apresentam-se neste capítulo, os resultados obtidos neste programa experimental referentes aos ensaios de percolação em colunas e ensaios triaxiais adensado e não drenado. Na Tabela 5.1 apresenta-se um resumo dos ensaios realizados. São informados o número total de ensaios que foram realizados e o número de ensaios aproveitados. Dentre os descartados, apresentam-se às causas para a sua inutilização. Busca-se mostrar quais e onde foram os maiores problemas encontrados. Os números apresentados são referentes aos três solos estudados.

A perda de corpos de prova durante a realização dos ensaios de percolação em colunas deve-se, principalmente, a problemas ocorridos durante o processo de compactação das amostras, tais como: grau de compactação não atingido e variação no teor de umidade de compactação. Os problemas ocorridos na realização dos ensaios triaxiais devem-se principalmente a: talhagem do corpo de prova (ruptura ou falta de planicidade entre o topo e a base do corpo de prova), funcionamento não adequado do equipamento (problemas na interface de pressão), vedação do corpo de prova no decorrer do ensaio (furo na membrana ou micro abertura na interface cap - membrana), sistema de aquisição de dados (falha na aquisição dos dados) e problemas na rede elétrica (falta de energia).

Tabela 5.1. Resumo dos ensaios laboratoriais realizados.

\begin{tabular}{ccc}
\hline Informações sobre os & \multicolumn{2}{c}{ Número de ensaios realizados } \\
\cline { 2 - 3 } ensaios & $\begin{array}{c}\text { Percolação em } \\
\text { colunas }\end{array}$ & Triaxial \\
\hline Total Realizado & 66 & 54 \\
Total Aproveitado & 56 & 36 \\
Problema na Compactação & 10 & 0 \\
Problema na Talhagem & 0 & 11 \\
Problema no Equipamento & 0 & 2 \\
Problema na Vedação do CP & 0 & 3 \\
Problema na Aquisição & 0 & 1 \\
Problema na Rede Elétrica & 0 & 1 \\
\hline
\end{tabular}




\subsection{ENSAIOS DE PERCOLAÇÃO EM COLUNA}

Os resultados obtidos com a realização dos ensaios de percolação em colunas de solos, conforme já mencionado no Capítulo 3, geralmente são apresentados por meio de uma curva de chegada. Salienta-se que as Figuras representativas dessas curvas de chegada encontram-se no Apêndice A. Os resultados dos ensaios de percolação em colunas estão sintetizados nas Tabelas 5.2, 5.3 e 5.4, para os solos Serra Geral, Botucatu e a mistura, respectivamente. Essas tabelas também apresentam os valores médios, mínimos e máximos de condutividade hidráulica obtidos durante as fases de percolação com água destilada e deionizada e com as soluções contaminantes nas diferentes concentrações.

Tabela 5.2. Resultados do ensaio de percolação em colunas para o solo Serra Geral.

\begin{tabular}{|c|c|c|c|c|c|c|c|c|c|c|}
\hline \multirow[b]{2}{*}{ Amostra } & \multirow{2}{*}{$\underset{(\mathrm{mg} / \mathrm{L})}{\mathrm{C}}$} & \multicolumn{3}{|c|}{ Percolação Água Destilada } & \multicolumn{6}{|c|}{ Percolação Solução Contaminante } \\
\hline & & $\begin{array}{c}\mathbf{k}_{\min } \\
\left(10^{-9} \mathrm{~m} / \mathrm{s}\right)\end{array}$ & $\begin{array}{c}\mathbf{k}_{\text {máx }} \\
\left(10^{-9} \mathbf{m} / \mathbf{s}\right)\end{array}$ & $\begin{array}{c}\mathbf{k}_{\mathrm{med}} \\
\left(10^{-9} \mathrm{~m} / \mathrm{s}\right)\end{array}$ & $\begin{array}{l}\mathbf{V}_{p} \\
(\mathrm{ml})\end{array}$ & \multicolumn{2}{|c|}{$T_{p}\left(C / C_{0}=1\right)$} & $\begin{array}{c}\mathbf{k}_{\min } \\
\left(10^{-9} \mathrm{~m} / \mathrm{s}\right)\end{array}$ & $\begin{array}{c}\mathbf{k}_{\text {máx }} \\
\left(10^{-9} \mathrm{~m} / \mathrm{s}\right)\end{array}$ & $\begin{array}{c}\mathbf{k}_{\mathrm{med}} \\
\left(10^{-9} \mathrm{~m} / \mathrm{s}\right)\end{array}$ \\
\hline 1 & 0 & 1,37 & 2,72 & 1,62 & - & - & - & - & - & \\
\hline 2 & 0 & 2,35 & 3,02 & 2,53 & - & - & - & - & - & \\
\hline 3 & 0 & 1,69 & 3,41 & 2,43 & - & - & - & - & - & \\
\hline 4 & 50 & 0,80 & 1,08 & 0,94 & 23034 & 50,5 & 20,4 & 1,53 & 2,81 & 2,25 \\
\hline 5 & 50 & 1,37 & 1,48 & 1,40 & 24720 & 54,3 & 19,02 & 2,09 & 3,68 & 3,18 \\
\hline 6 & 50 & 1,12 & 1,42 & 1,27 & 23560 & 51,7 & 21,9 & 1,33 & 3,05 & 2,55 \\
\hline 7 & 300 & 1,04 & 2,89 & 1,81 & 13665 & 29,8 & 17,3 & 2,75 & 3,92 & 2,98 \\
\hline 8 & 300 & 0,83 & 0,94 & 0,93 & 13190 & 29,0 & 18,4 & 0,93 & 2,20 & 1,68 \\
\hline 9 & 300 & 1,17 & 1,83 & 1,63 & 13780 & 30,3 & 17,8 & 1,69 & 3,61 & 3,19 \\
\hline 10 & 600 & 0,89 & 1,58 & 1,23 & 11295 & 24,9 & 16,3 & 1,78 & 2,48 & 2,17 \\
\hline 11 & 600 & 1,04 & 3,45 & 1,75 & 11820 & 25,9 & 19,6 & 3,96 & 5,06 & 4,23 \\
\hline 12 & 600 & 0,78 & 1,01 & 0,91 & 11145 & 24,4 & 17,2 & 1,13 & 2,87 & 2,26 \\
\hline
\end{tabular}

Tabela 5.3. Resultado do ensaio de percolação em colunas para o solo Botucatu.

\begin{tabular}{|c|c|c|c|c|c|c|c|c|c|c|}
\hline \multirow{3}{*}{ Amostra } & \multirow{3}{*}{$\begin{array}{c}\mathrm{C} \\
(\mathrm{mg} / \mathrm{L})\end{array}$} & \multicolumn{3}{|c|}{ Percolação Água Destilada } & \multicolumn{6}{|c|}{ Percolação Solução Contaminante } \\
\hline & & \multirow{2}{*}{$\begin{array}{c}k_{\min } \\
\left(10^{-8} \mathrm{~m} / \mathrm{s}\right)\end{array}$} & \multirow{2}{*}{$\begin{array}{c}\mathbf{k}_{\text {máx }} \\
\left(10^{-8} \mathrm{~m} / \mathrm{s}\right)\end{array}$} & \multirow{2}{*}{$\begin{array}{c}\mathbf{k}_{\text {med }} \\
\left(10^{-8} \mathrm{~m} / \mathrm{s}\right)\end{array}$} & \multirow{2}{*}{$\begin{array}{c}V_{p} \\
(\mathrm{ml})\end{array}$} & \multicolumn{2}{|c|}{$T_{p}\left(C / C_{0}=1\right)$} & \multirow{2}{*}{$\begin{array}{c}k_{\min } \\
\left(10^{-8} \mathrm{~m} / \mathrm{s}\right)\end{array}$} & \multirow{2}{*}{$\begin{array}{c}k_{\text {máx }} \\
\left(10^{-8} \mathrm{~m} / \mathrm{s}\right)\end{array}$} & \multirow{2}{*}{$\begin{array}{c}\mathbf{k}_{\text {med }} \\
\left(10^{-8} \mathrm{~m} / \mathrm{s}\right)\end{array}$} \\
\hline & & & & & & $\mathrm{Cu}^{+2}$ & $\mathrm{Cl}^{-1}$ & & & \\
\hline 1 & 0 & 9,81 & 10,4 & 10,1 & - & - & - & - & - & \\
\hline 2 & 0 & 8,78 & 9,95 & 9,25 & - & - & - & - & - & \\
\hline 3 & 0 & 8,68 & 9,52 & 9,13 & - & - & - & - & - & \\
\hline 4 & 50 & 9,68 & 10,2 & 9,95 & 5390 & 18,68 & 8,46 & 6,92 & 8,0 & 7,12 \\
\hline 5 & 50 & 8,40 & 10,1 & 8,90 & 5680 & 19,82 & 8,06 & 6,03 & 8,14 & 7,09 \\
\hline 6 & 50 & 6,72 & 8,95 & 8,05 & 5380 & 18,24 & 7,56 & 5,83 & 8,51 & 7,40 \\
\hline 7 & 300 & 7,81 & 9,88 & 8,51 & 4110 & 14,13 & 7,89 & 7,91 & 9,36 & 8,67 \\
\hline 8 & 300 & 7,37 & 9,79 & 8,23 & 4350 & 15,0 & 8,41 & 6,44 & 7,55 & 7,05 \\
\hline 9 & 300 & 7,59 & 9,14 & 8,28 & 4075 & 14,06 & 7,55 & 7,40 & 9,52 & 8,74 \\
\hline 10 & 600 & 7,34 & 9,59 & 8,74 & 4250 & 14,8 & 7,75 & 7,73 & 9,93 & 9,12 \\
\hline 11 & 600 & 8,23 & 11,5 & 9,80 & 4750 & 16,6 & 6,4 & 8,70 & 9,95 & 9,36 \\
\hline 12 & 600 & 8,89 & 17,4 & 10,3 & 4410 & 15,47 & 8,38 & 9,05 & 19,3 & 11,5 \\
\hline
\end{tabular}


Tabela 5.4. Resultados do ensaio de percolação em colunas para a mistura.

\begin{tabular}{|c|c|c|c|c|c|c|c|c|c|c|}
\hline \multirow[b]{2}{*}{ Amostra } & \multirow{2}{*}{$\begin{array}{c}\mathrm{C} \\
(\mathrm{mg} / \mathrm{L})\end{array}$} & \multicolumn{3}{|c|}{ Percolação Água Destilada } & \multicolumn{6}{|c|}{ Percolação Solução Contaminante } \\
\hline & & $\begin{array}{c}\mathbf{k}_{\min } \\
\left(10^{-8} \mathrm{~m} / \mathbf{s}\right)\end{array}$ & $\begin{array}{c}\mathbf{k}_{\text {máx }} \\
\left(10^{-8} \mathrm{~m} / \mathrm{s}\right)\end{array}$ & $\begin{array}{c}\mathbf{k}_{\text {med }} \\
\left(10^{-8} \mathrm{~m} / \mathrm{s}\right)\end{array}$ & $\begin{array}{c}\mathrm{V}_{\mathrm{p}} \\
(\mathrm{ml})\end{array}$ & \multicolumn{2}{|c|}{$T_{p}\left(C / C_{0}=1\right)$} & $\begin{array}{c}\mathbf{k}_{\min } \\
\left(10^{-8} \mathrm{~m} / \mathrm{s}\right)\end{array}$ & $\begin{array}{c}\mathbf{k}_{\text {máx }} \\
\left(10^{-8} \mathrm{~m} / \mathbf{s}\right)\end{array}$ & $\begin{array}{c}\mathbf{k}_{\mathrm{med}} \\
\left(10^{-8} \mathrm{~m} / \mathrm{s}\right)\end{array}$ \\
\hline 1 & 0 & 1,98 & 3,42 & 2,80 & - & - & - & - & - & \\
\hline 2 & 0 & 1,12 & 3,27 & 2,17 & - & - & - & - & - & \\
\hline 3 & 0 & 1,53 & 3,92 & 2,38 & - & - & - & - & - & \\
\hline 4 & 50 & 1,19 & 1,49 & 1,38 & 8420 & 26,3 & 13,9 & 1,49 & 4,20 & 2,28 \\
\hline 5 & 50 & 1,92 & 3,82 & 2,39 & 8270 & 26,7 & 13,2 & 3,82 & 5,18 & 4,53 \\
\hline 6 & 50 & 1,28 & 2,35 & 1,70 & 7990 & 25,2 & 14,5 & 2,35 & 5,25 & 3,33 \\
\hline 7 & 300 & 1,05 & 1,89 & 1,29 & 7770 & 24,4 & 15,6 & 1,80 & 4,15 & 2,33 \\
\hline 8 & 300 & 0,89 & 0,93 & 0,91 & 7455 & 23,4 & 14,8 & 0,95 & 3,91 & 2,01 \\
\hline 9 & 300 & 0,91 & 0,93 & 0,92 & 7535 & 23,5 & 14,1 & 0,94 & 3,53 & 2,10 \\
\hline 10 & 600 & 1,93 & 2,00 & 1,97 & 6370 & 19,9 & 10,3 & 2,58 & 5,40 & 3,76 \\
\hline 11 & 600 & 1,50 & 1,78 & 1,65 & 6775 & 21,2 & 11,5 & 1,78 & 3,06 & 0,27 \\
\hline 12 & 600 & 1,86 & 2,50 & 2,05 & 6670 & 22,0 & 12,9 & 2,80 & 5,20 & 3,86 \\
\hline
\end{tabular}

Os valores de condutividade hidráulica foram calculados a partir da equação de Darcy e referenciados à temperatura de $20^{\circ} \mathrm{C}$ para padronizar o efeito da viscosidade com a temperatura, Seu cálculo foi feito pela expressão:

$$
k_{20}=\frac{\mu_{T}}{\mu_{20}} k_{T}
$$

onde:

$k_{20}=$ condutividade hidráulica a $20^{\circ} \mathrm{C}$;

$k_{T}=$ condutividade hidráulica na temperatura do ensaio;

$\mu_{T}=$ viscosidade do fluído na temperatura do ensaio;

$\mu_{20}=$ viscosidade do fluido à temperatura de $20^{\circ} \mathrm{C}$.

$\mathrm{O}$ volume percolado $(V p)$ está relacionado ao término do ensaio. Os fatores $T p$ correspondentes a $\mathrm{Cu}^{+2}$ e $\mathrm{Cl}^{-1}$ representam os instantes de completa adsorção dos íons $\mathrm{Cu}^{+2} \mathrm{e}$ $\mathrm{Cl}^{-1}$, respectivamente.

\subsection{ENSAIOS TRIAXIAIS}

Para melhor avaliar o efeito da contaminação nos solos estudados, apresentam-se os resultados dos corpos de prova percolados com as concentrações de $0,50 \mathrm{mg} / \mathrm{L}$ e 600 mg/L. Para cada concentração de cloreto de cobre analisada, serão apresentadas três curvas, uma para cada tensão de confinamento $(50,100$ e $200 \mathrm{kPa})$. Os resultados serão apresentados separadamente, para cada solo estudado. 


\subsubsection{Solo Serra Geral}

- $\quad$ Solo Serra Geral percolado com água destilada $(C=0)$

Nesta série os ensaios foram realizados em três corpos de prova percolados com água destilada, ou seja, concentração 0 . Os corpos de prova foram submetidos a tensões de confinamento de 50, 100 e $200 \mathrm{kPa}$. Os resultados correspondentes à fase de adensamento são apresentados em curvas de Variação volumétrica (\%) versus $V_{t}$ (minutos) (Figura 5.1). Os resultados correspondentes à fase de cisalhamento são apresentados em curvas de Tensão desvio ( $\mathrm{kPa}$ ) versus Deformação axial (\%) (Figura 5.2) e de Pressão neutra (kPa) versus Deformação axial (\%) (Figura 5.3).

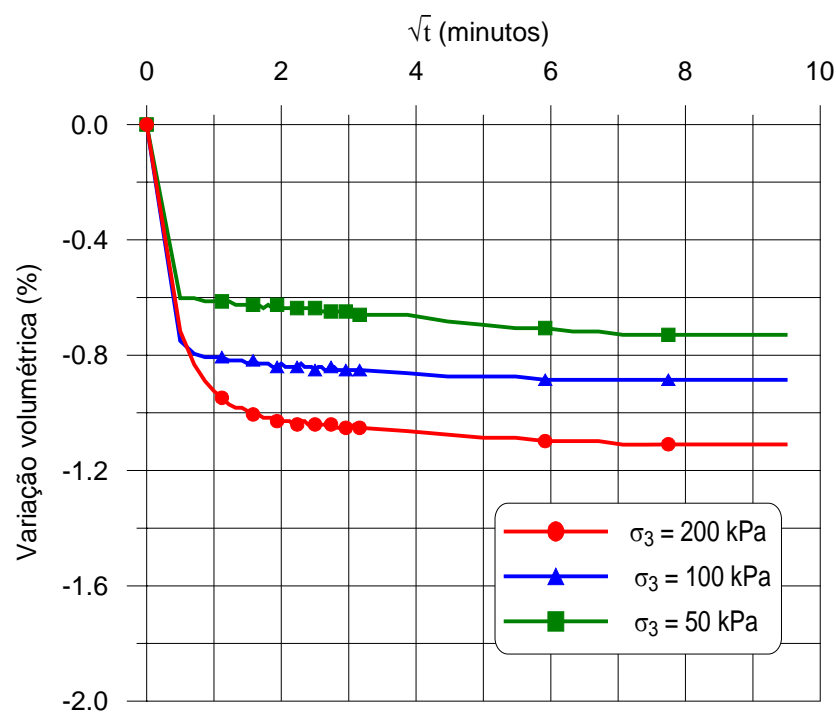

Figura 5.1. Curvas de Variação volumétrica (\%) versus $\downarrow$ t, sendo o tempo em minutos.

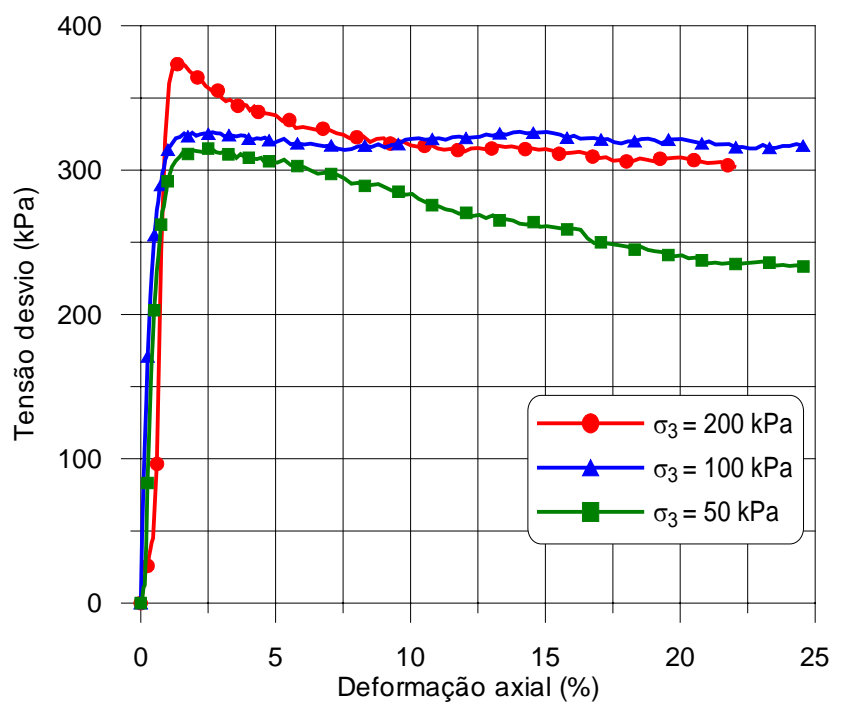

Figura 5.2. Curvas de Tensão desvio versus Deformação axial. 


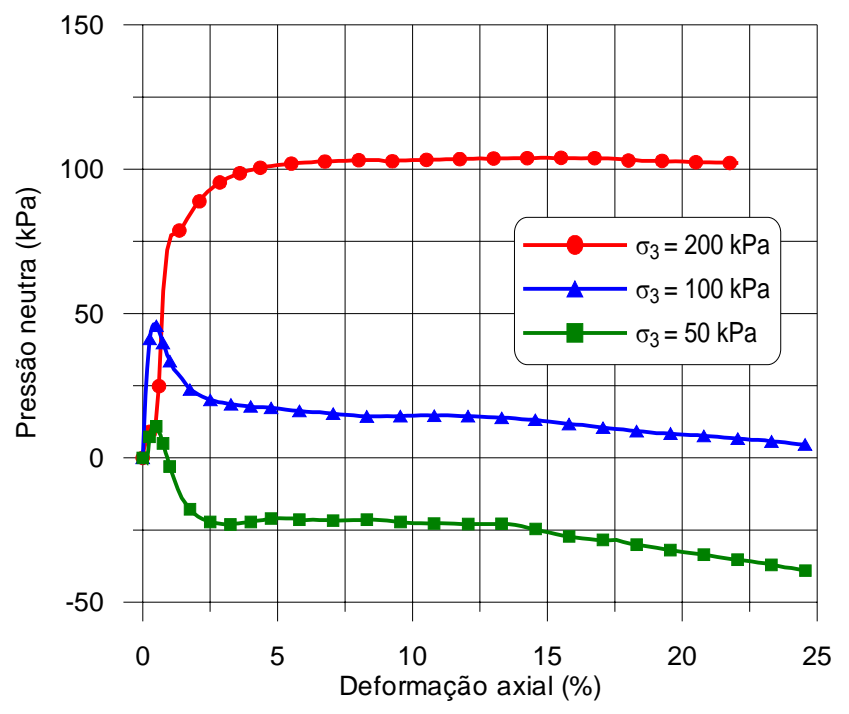

Figura 5.3. Curvas de Pressão neutra versus Deformação axial.

- $\quad$ Solo Serra Geral percolado com solução contaminante de $50 \mathrm{mg} / \mathrm{L}$

Nesta série os ensaios foram realizados em três corpos de prova percolados com solução contaminante de concentração $50 \mathrm{mg} / \mathrm{L}$. Os corpos de prova foram submetidos a tensões de confinamento de 50,100 e $200 \mathrm{kPa}$. Os resultados correspondentes à fase de adensamento são apresentados em curvas de Variação volumétrica (\%) versus $\bigvee_{t}$ (minutos) (Figura 5.4). Os resultados correspondentes à fase de cisalhamento são apresentados em curvas de Tensão desvio ( $\mathrm{kPa}$ ) versus Deformação axial (\%) (Figura 5.5) e de Pressão neutra $(\mathrm{kPa})$ versus Deformação axial (\%) (Figura 5.6).

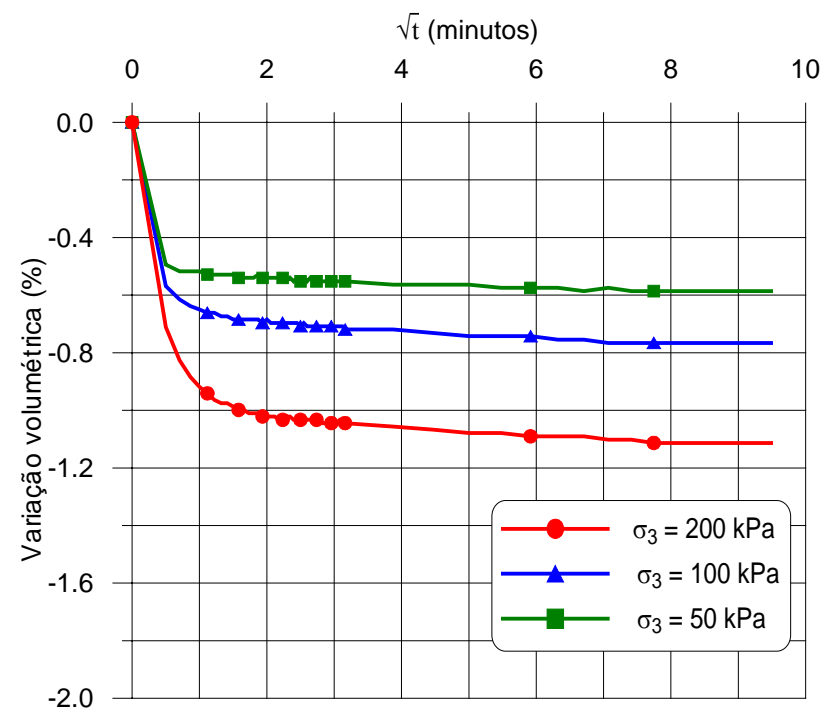

Figura 5.4. Curvas de Variação volumétrica (\%) versus $\downarrow$ t, sendo o tempo em minutos. 


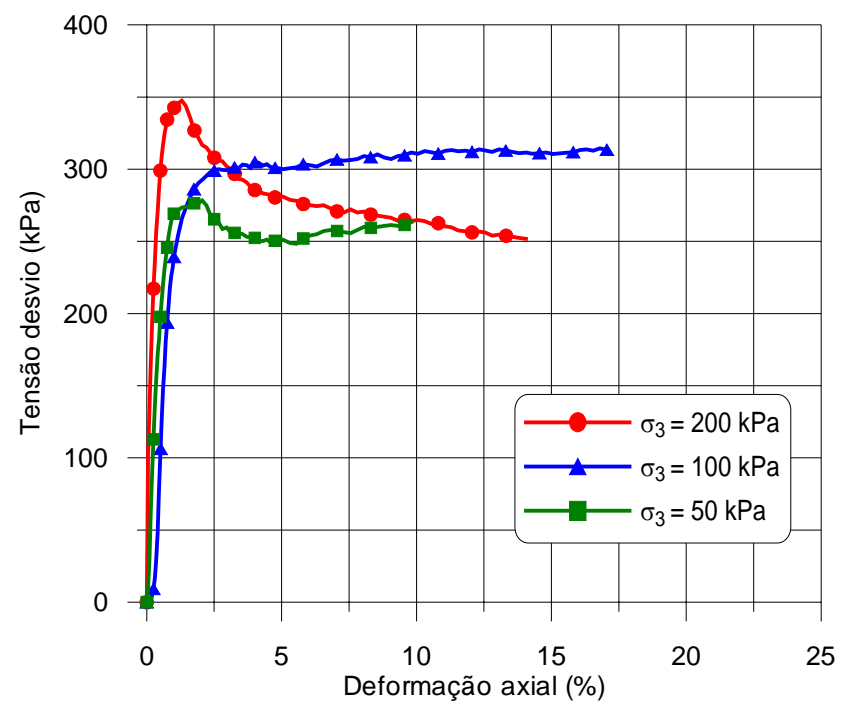

Figura 5.5. Curvas de Tensão desvio versus Deformação axial.

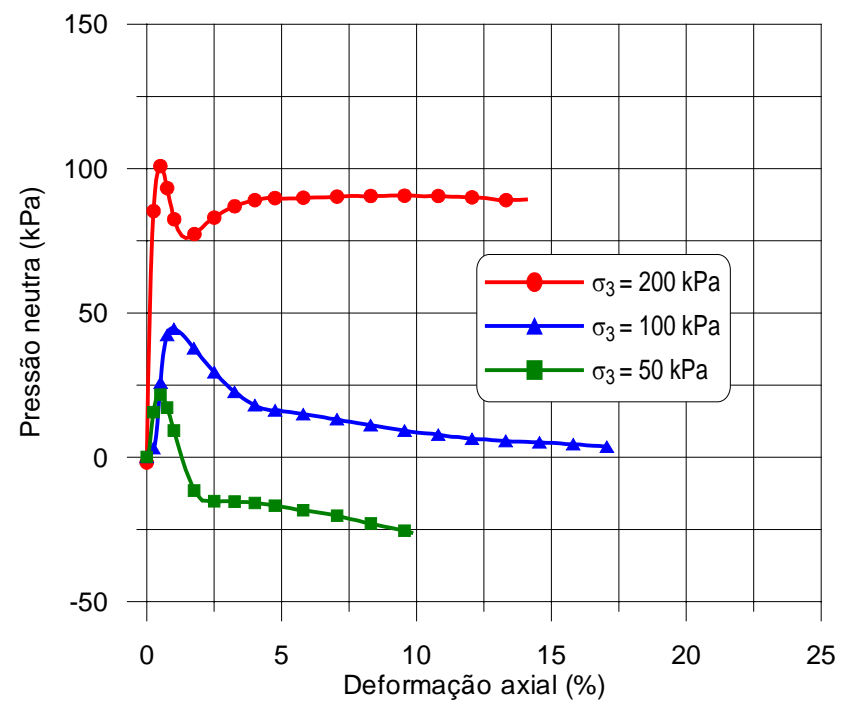

Figura 5.6. Curvas de Pressão neutra versus Deformação axial.

- Solo Serra Geral percolado com solução contaminante de $300 \mathrm{mg} / \mathrm{L}$

Nesta série os ensaios foram realizados em três corpos de prova percolados com solução contaminante de concentração $300 \mathrm{mg} / \mathrm{L}$. Os corpos de prova foram submetidos a tensões de confinamento de 50,100 e $200 \mathrm{kPa}$. Os resultados da fase de adensamento são apresentados em curvas de Variação volumétrica (\%) versus $\sqrt{t}_{t}$ (minutos) (Figura 5.7). Os resultados correspondentes à fase de cisalhamento são apresentados em curvas de Tensão desvio ( $\mathrm{kPa}$ ) versus Deformação axial (\%) (Figura 5.8) e de Pressão neutra (kPa) versus Deformação axial (\%) (Figura 5.9). 


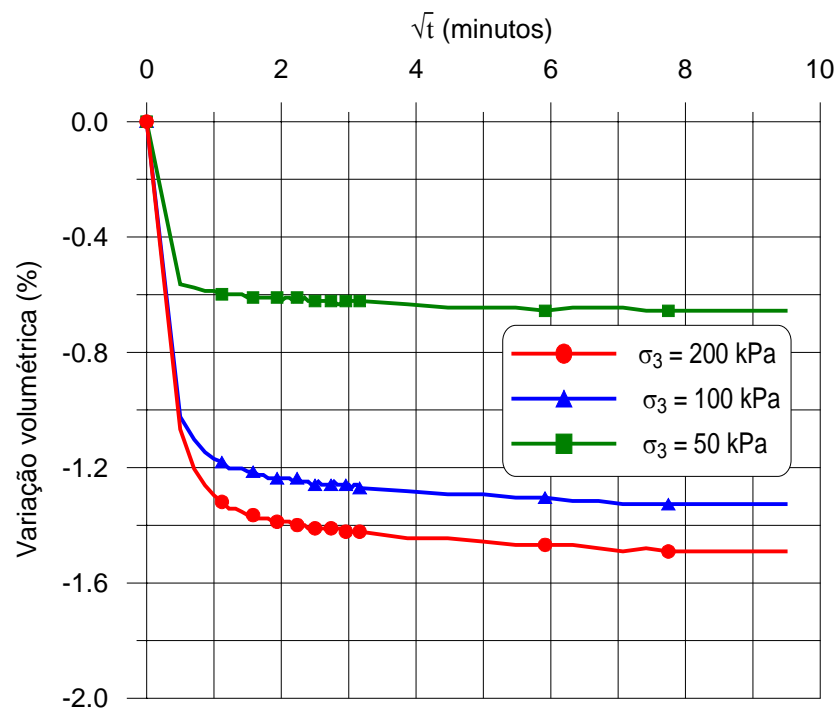

Figura 5.7. Curvas de Variação volumétrica (\%) versus $\downarrow t$, sendo o tempo em minutos.

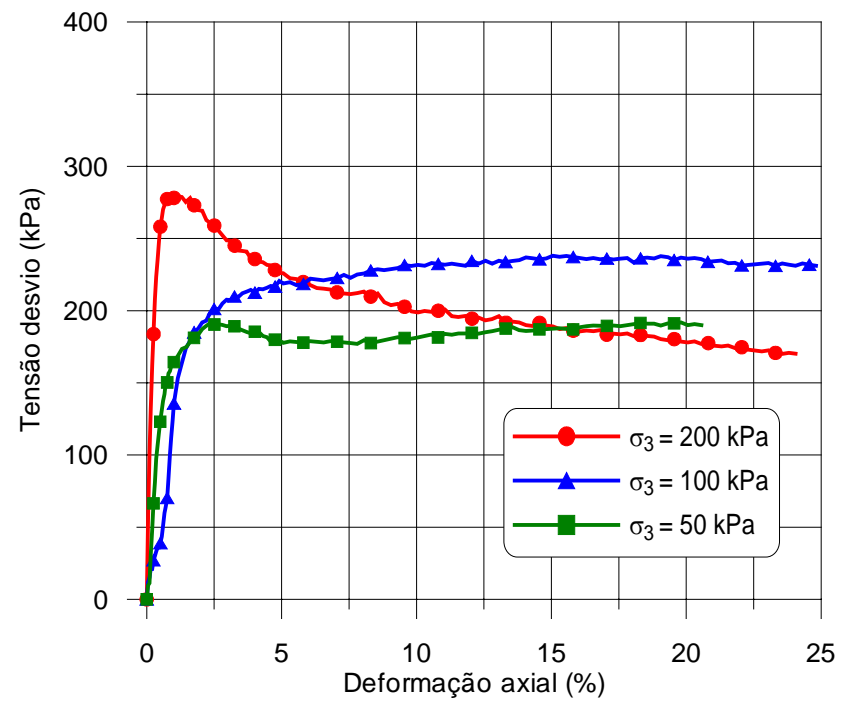

Figura 5.8. Curvas de Tensão Desvio versus Deformação axial.

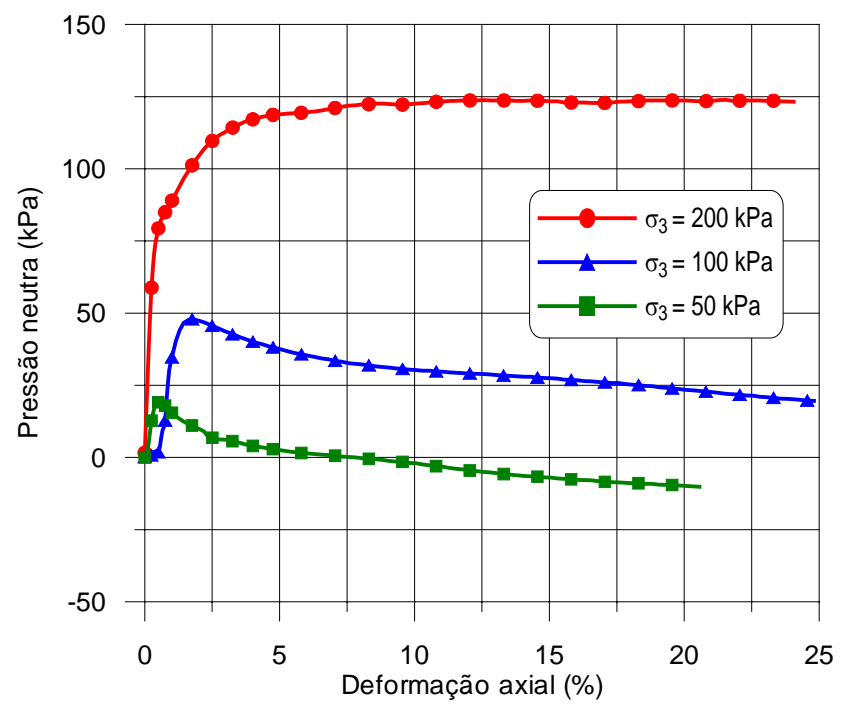

Figura 5.9. Curvas de Pressão neutra versus Deformação axial. 
- Solo Serra Geral percolado com solução contaminante de $600 \mathrm{mg} / \mathrm{L}$

Nesta série os ensaios foram realizados em três corpos de prova percolados com solução contaminante de concentração $600 \mathrm{mg} / \mathrm{L}$. Os corpos de prova foram submetidos a tensões de confinamento de 50,100 e $200 \mathrm{kPa}$. Os resultados correspondentes à fase de adensamento são apresentados em curvas de Variação volumétrica (\%) versus $\bigvee_{t}$ (minutos) (Figura 5.10). Os resultados correspondentes à fase de cisalhamento são apresentados em curvas de Tensão desvio (kPa) versus Deformação axial (\%) (Figura 5.11) e de Pressão neutra (kPa) versus Deformação axial (\%) (Figura 5.12).

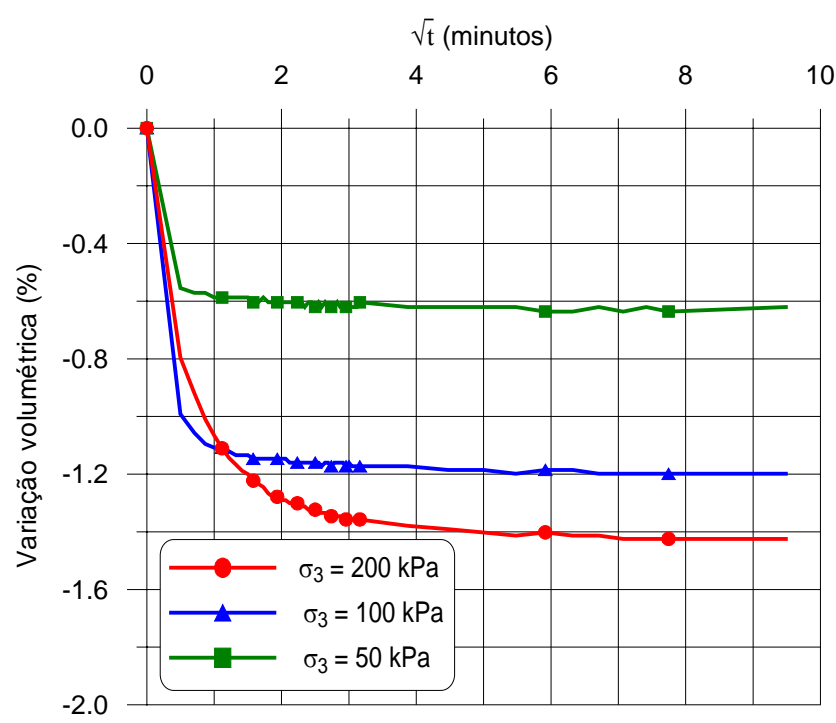

Figura 5.10. Curvas de Variação volumétrica (\%) versus 1 t, sendo o tempo em minutos.

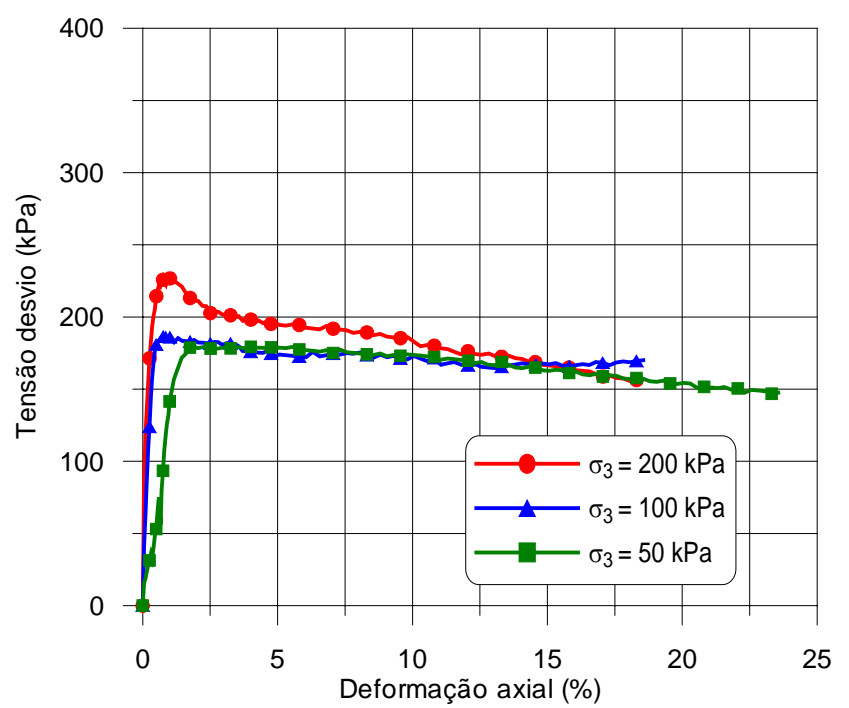

Figura 5.11. Curvas de Tensão desvio versus Deformação axial. 


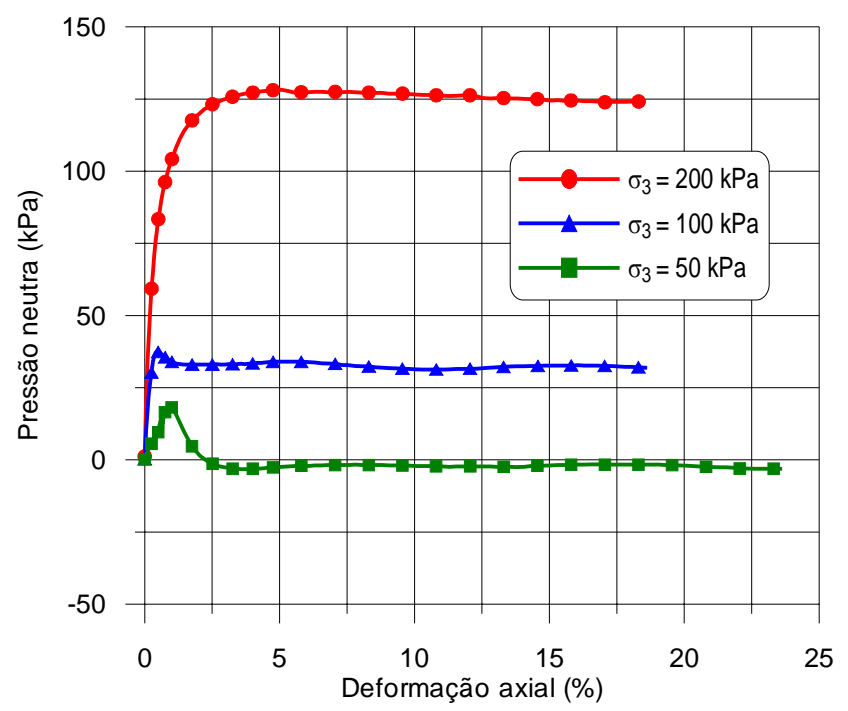

Figura 5.12. Curvas de Pressão neutra versus Deformação axial.

\subsubsection{Solo Botucatu}

- $\quad$ Solo Botucatu percolado com água destilada $(C=0)$

Nesta série os ensaios foram realizados em três corpos de prova percolados com água destilada, ou seja, concentração 0. Os corpos de prova foram submetidos a tensões de confinamento de 50, 100 e $200 \mathrm{kPa}$. Os resultados correspondentes à fase de adensamento são apresentados em curvas de Variação volumétrica (\%) versus $V_{t}$ (minutos) (Figura 5.13). Os resultados correspondentes à fase de cisalhamento são apresentados em curvas de Tensão desvio ( $\mathrm{kPa}$ ) versus Deformação axial (\%) (Figura 5.14) e de Pressão neutra (kPa) versus Deformação axial (\%) (Figura 5.15).

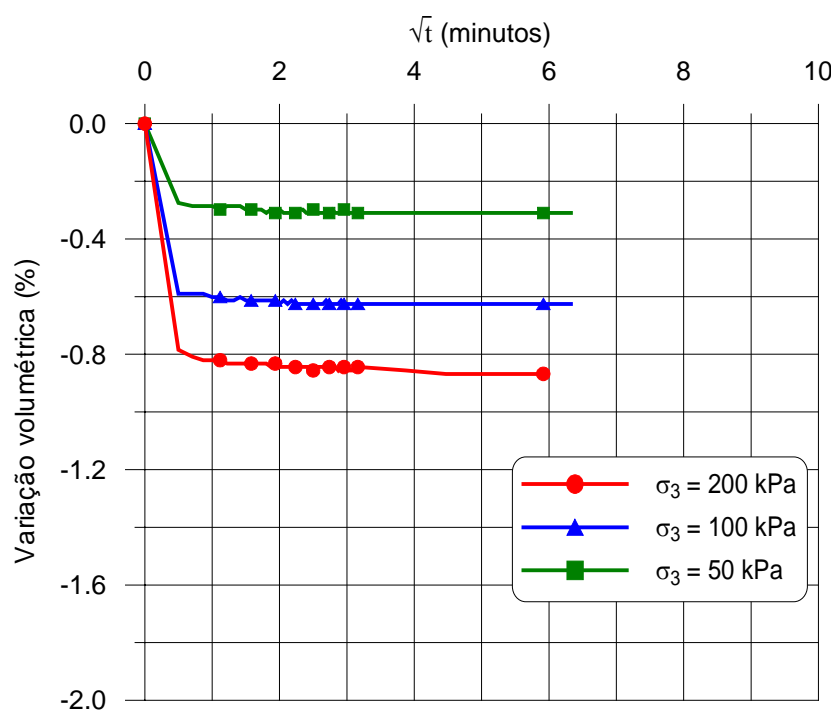

Figura 5.13. Curvas de Variação volumétrica (\%) versus 1 , sendo o tempo em minutos. 


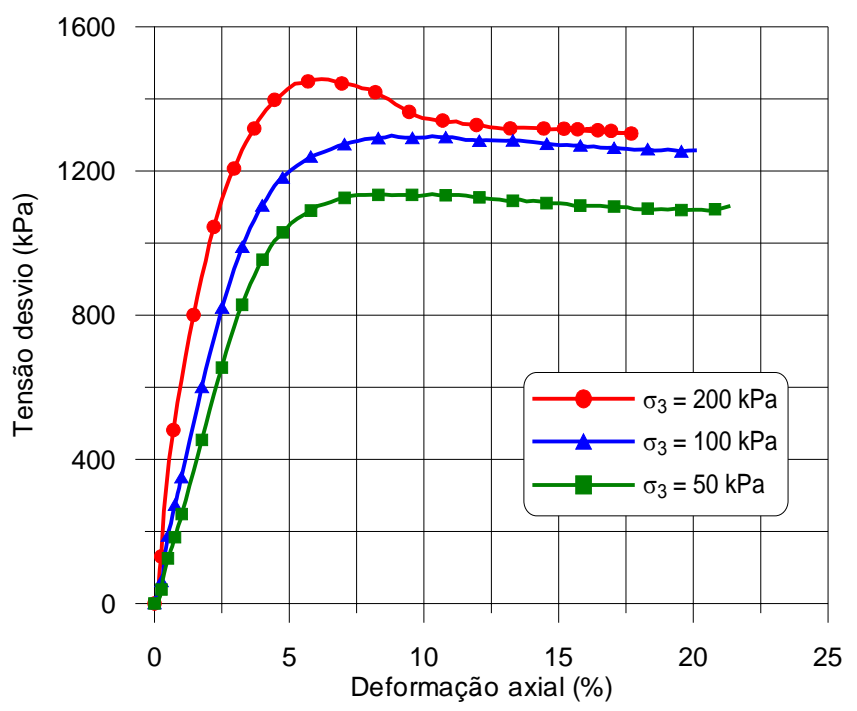

Figura 5.14. Curvas de Tensão desvio versus Deformação axial.

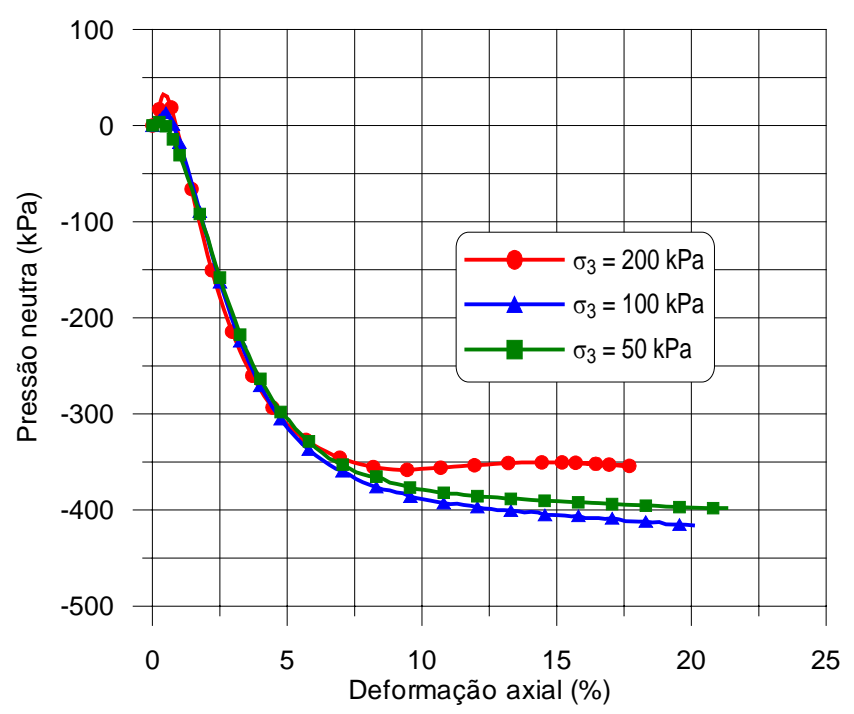

Figura 5.15. Curvas de Pressão neutra versus Deformação axial.

- $\quad$ Solo Botucatu percolado com solução contaminante de $50 \mathrm{mg} / \mathrm{L}$

Nesta série os ensaios foram realizados em três corpos de prova percolados com solução contaminante de concentração $50 \mathrm{mg} / \mathrm{L}$. Os corpos de prova foram submetidos a tensões de confinamento de 50,100 e $200 \mathrm{kPa}$. Os resultados correspondentes à fase de adensamento são apresentados em curvas de Variação volumétrica (\%) versus $V_{t}$ (minutos) (Figura 5.16). Os resultados correspondentes à fase de cisalhamento são apresentados em curvas de Tensão desvio ( $\mathrm{kPa}$ ) versus Deformação axial (\%) (Figura 5.17) e de Pressão neutra ( $\mathrm{kPa}$ ) versus Deformação axial (\%) (Figura 5.18). 


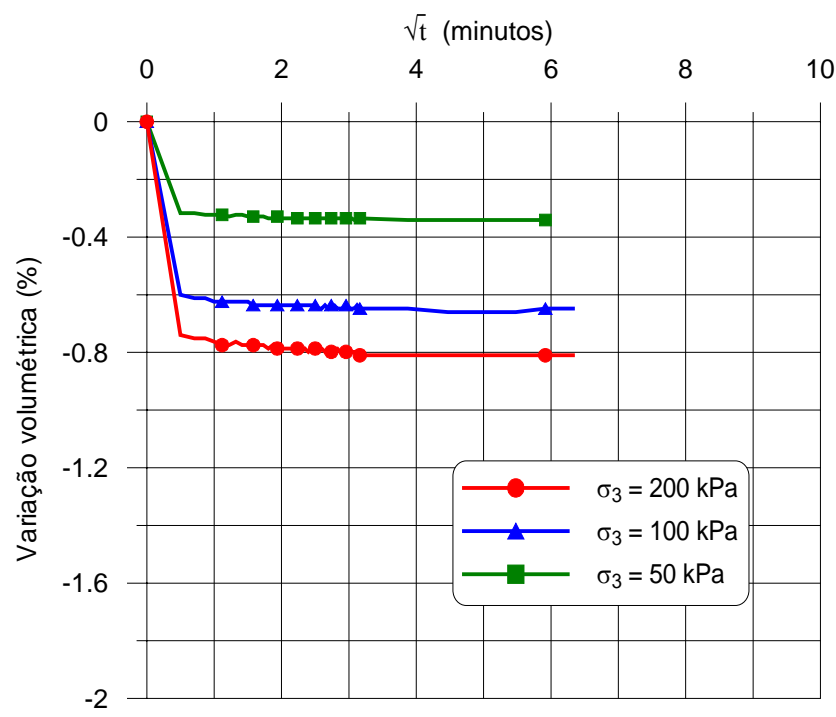

Figura 5.16. Curvas de Variação volumétrica (\%) versus $1 t$, sendo o tempo em minutos.

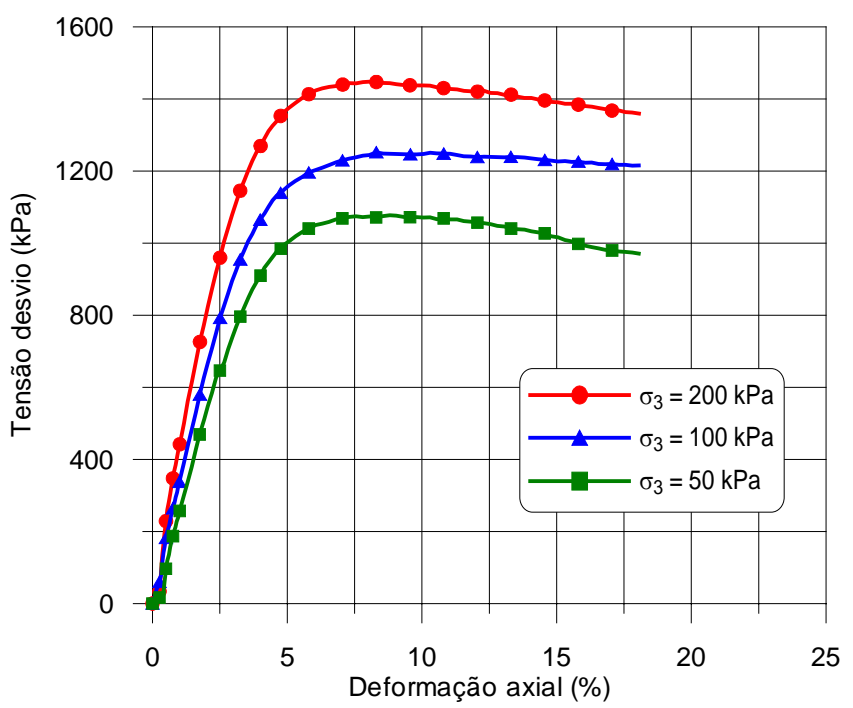

Figura 5.17. Curvas de Tensão desvio versus Deformação axial.

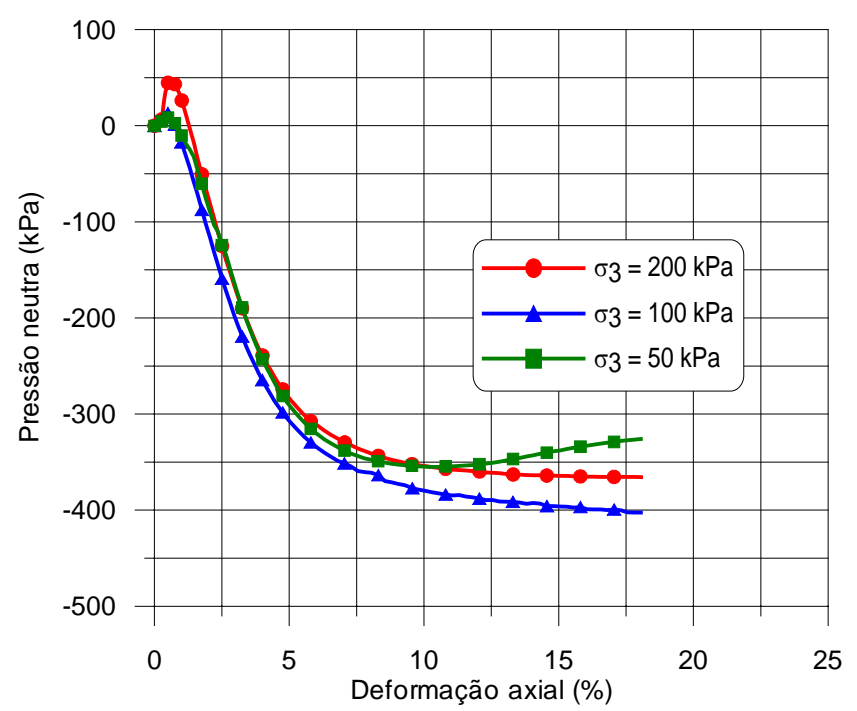

Figura 5.18. Curvas de Pressão neutra versus Deformação axial. 
- $\quad$ Solo Botucatu percolado com solução contaminante de $300 \mathrm{mg} / \mathrm{L}$

Nesta série os ensaios foram realizados em três corpos de prova percolados com solução contaminante de concentração $300 \mathrm{mg} / \mathrm{L}$. Os corpos de prova foram submetidos a tensões de confinamento de 50,100 e $200 \mathrm{kPa}$. Os resultados correspondentes à fase de adensamento são apresentados em curvas de Variação volumétrica (\%) versus $\bigvee_{t}$ (minutos) (Figura 5.19). Os resultados correspondentes à fase de cisalhamento são apresentados em curvas de Tensão desvio ( $\mathrm{kPa}$ ) versus Deformação axial (\%) (Figura 5.20) e de Pressão neutra ( $\mathrm{kPa}$ ) versus Deformação axial (\%) (Figura 5.21).

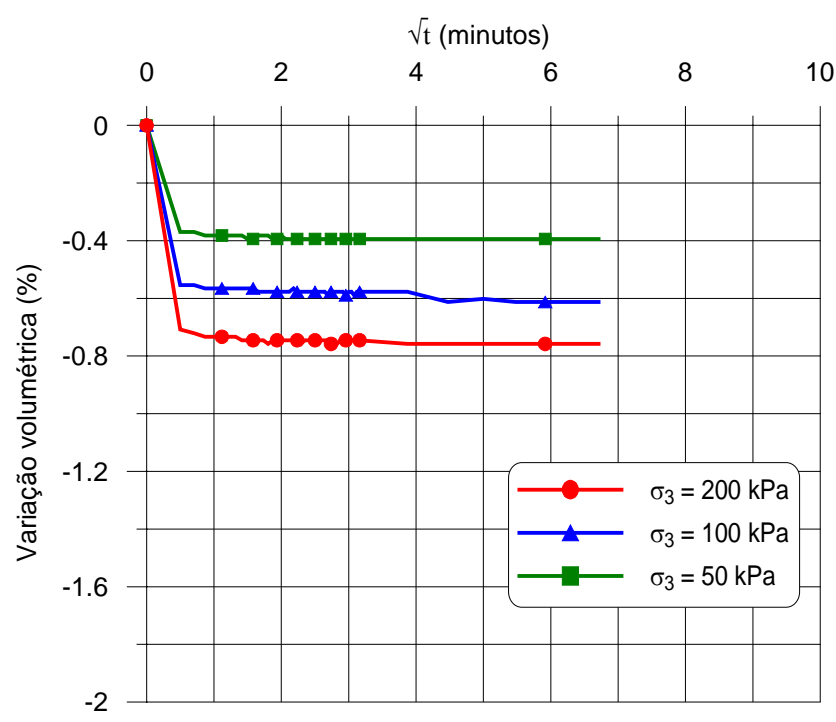

Figura 5.19. Curvas de Variação volumétrica (\%) versus $\sqrt{ }$, sendo o tempo em minutos.

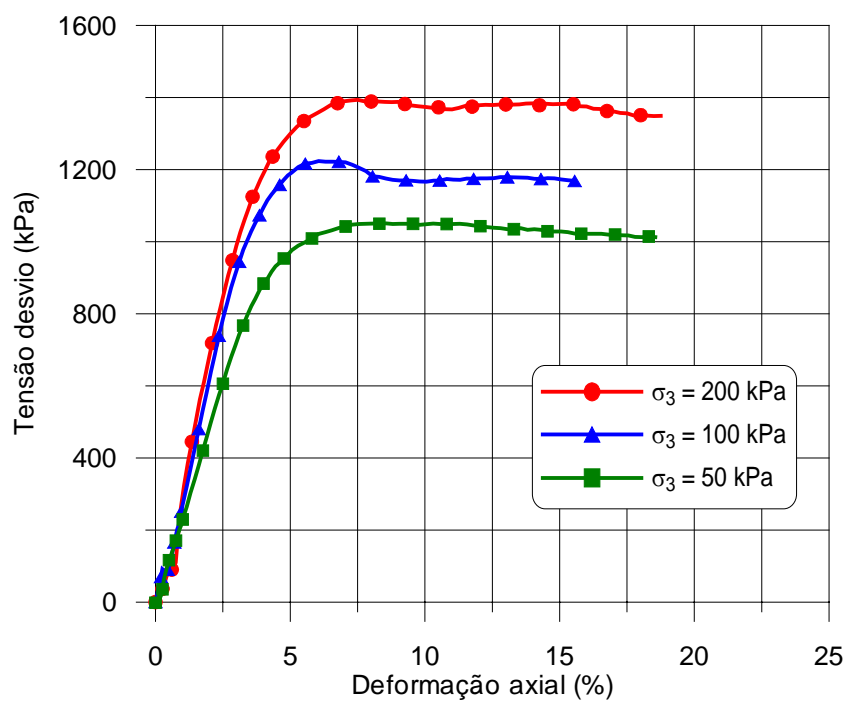

Figura 5.20. Curvas de Tensão Desvio versus Deformação axial. 


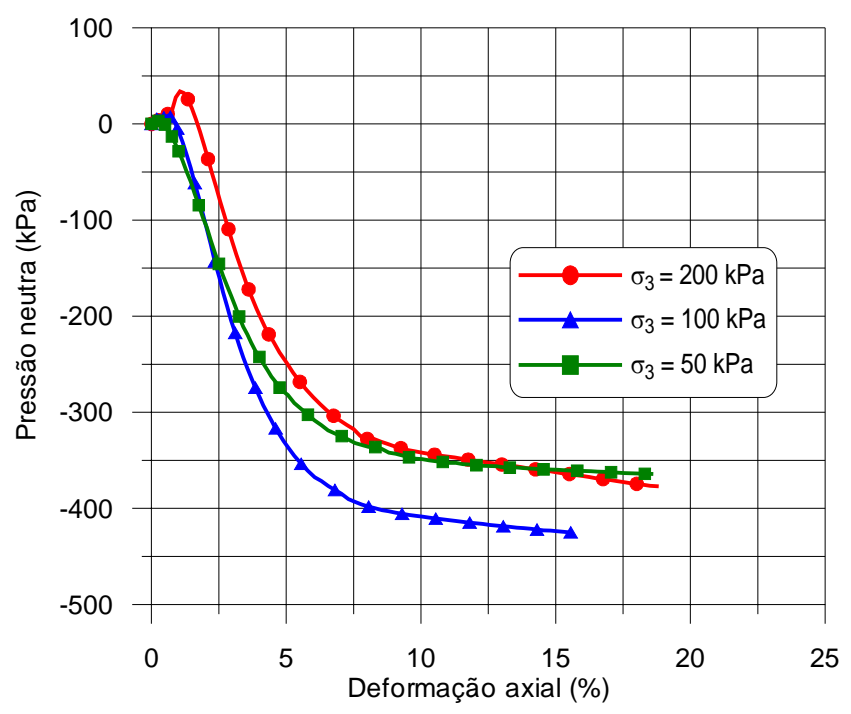

Figura 5.21. Curvas de Pressão neutra versus Deformação axial.

- $\quad$ Solo Botucatu percolado com solução contaminante de $600 \mathrm{mg} / \mathrm{L}$

Nesta série os ensaios foram realizados em três corpos de prova percolados com solução contaminante de concentração $600 \mathrm{mg} / \mathrm{L}$. Os corpos de prova foram submetidos a tensões de confinamento de 50,100 e $200 \mathrm{kPa}$. Os resultados correspondentes à fase de adensamento são apresentados em curvas de Variação volumétrica (\%) versus $\bigvee_{t}$ (minutos) (Figura 5.22). Os resultados correspondentes à fase de cisalhamento são apresentados em curvas de Tensão desvio (kPa) versus Deformação axial (\%) (Figura 5.23) e de Pressão neutra ( $k P a)$ versus Deformação axial (\%) (Figura 5.24).

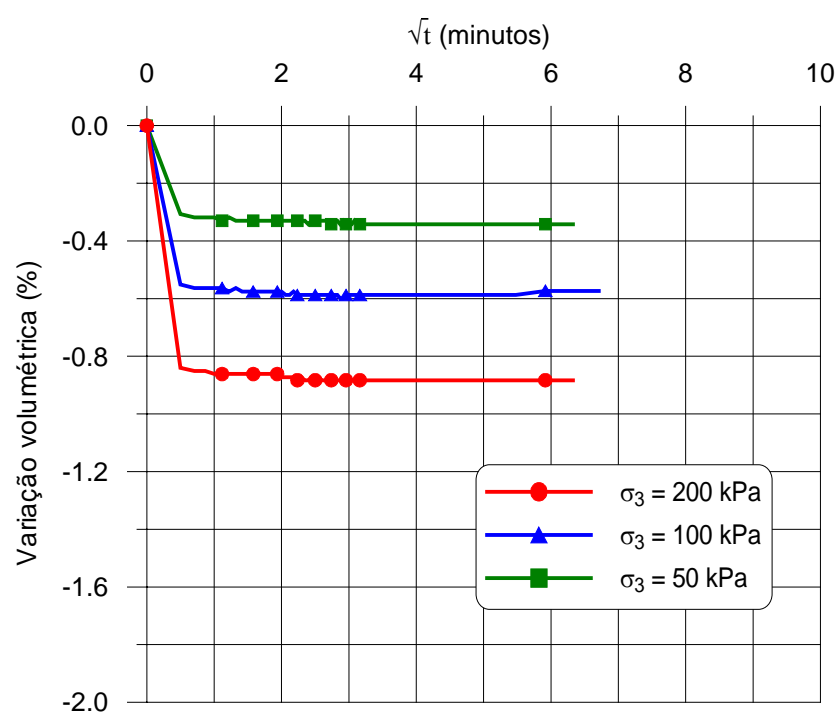

Figura 5.22. Curvas de Variação volumétrica (\%) versus 1 , sendo o tempo em minutos. 


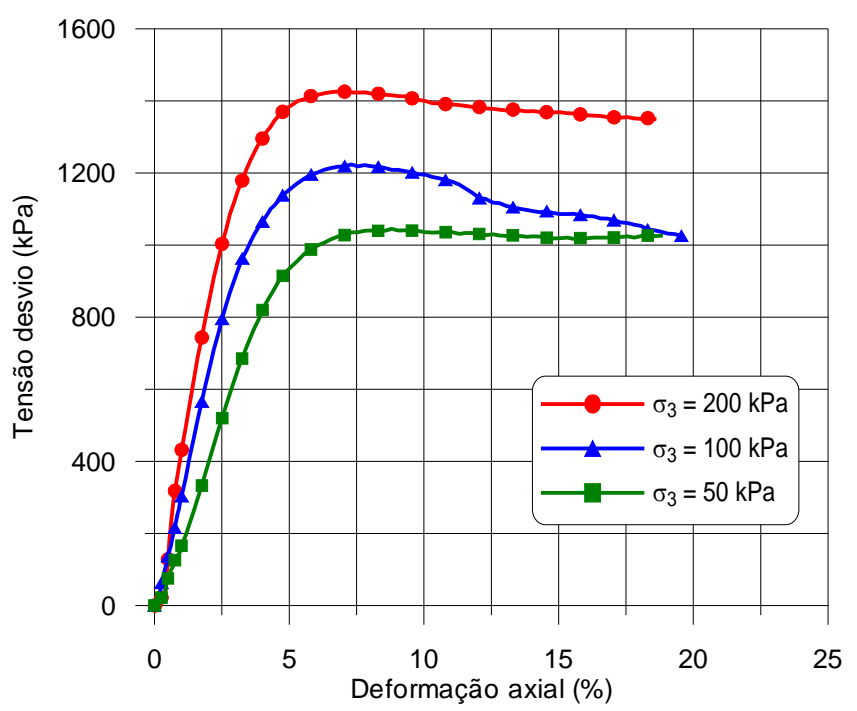

Figura 5.23. Curvas de Tensão desvio versus Deformação axial.

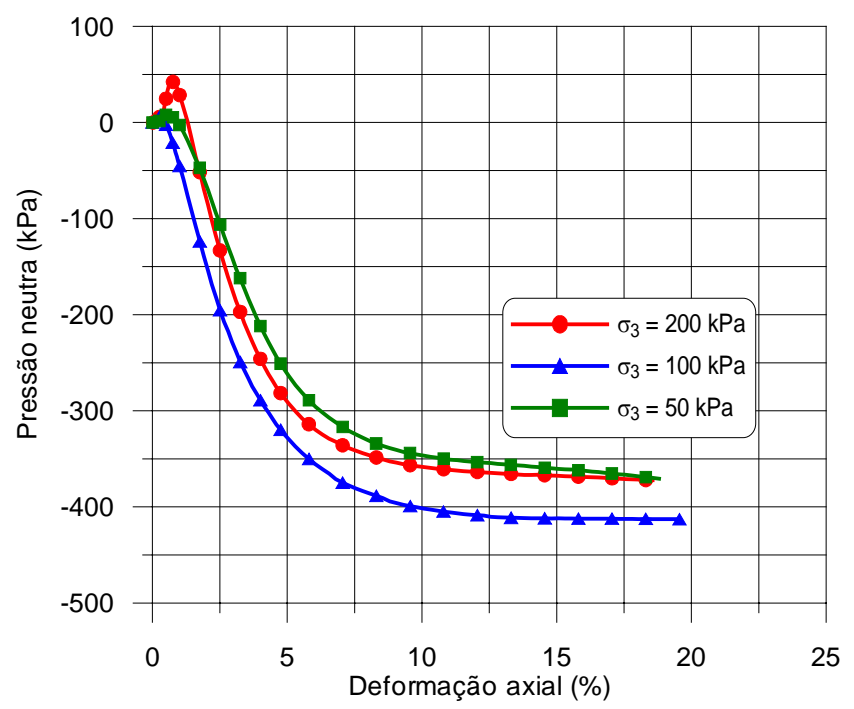

Figura 5.24. Curvas de Pressão neutra versus Deformação axial.

\subsubsection{Mistura $20 \%-80 \%$}

- $\quad$ Mistura percolada com água destilada $(C=0)$

Nesta série os ensaios foram realizados em três corpos de prova percolados com água destilada, ou seja, concentração 0. Os corpos de prova foram submetidos a tensões de confinamento de 50, 100 e $200 \mathrm{kPa}$. Os resultados correspondentes à fase de adensamento são apresentados em curvas de Variação volumétrica (\%) versus $V_{t}$ (minutos) (Figura 5.25). Os resultados correspondentes à fase de cisalhamento são apresentados em curvas de Tensão desvio ( $\mathrm{kPa}$ ) versus Deformação axial (\%) (Figura 5.26) e de Pressão neutra (kPa) versus Deformação axial (\%) (Figura 5.27). 


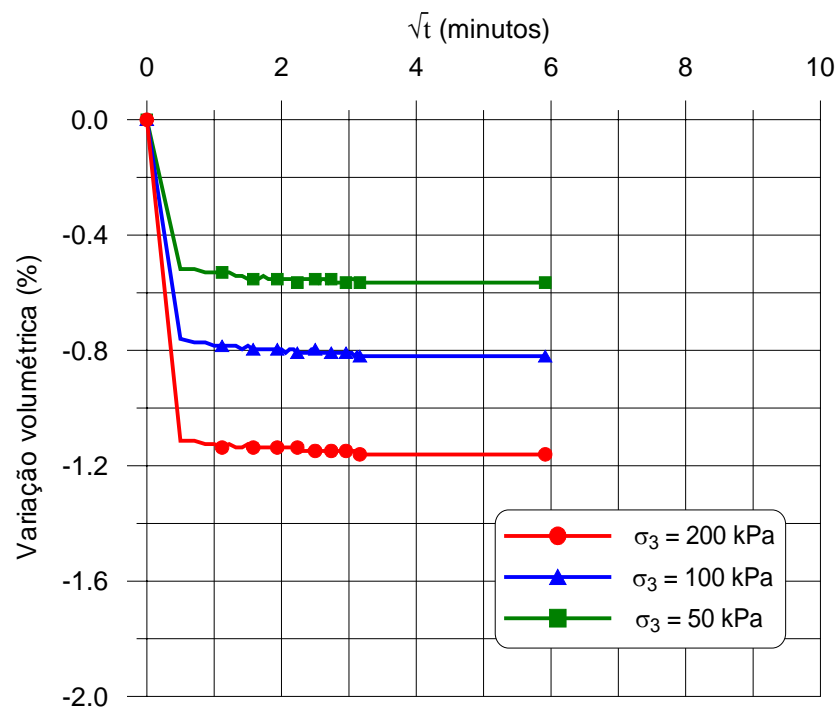

Figura 5.25. Curvas de Variação volumétrica (\%) versus $1 t$, sendo o tempo em minutos.

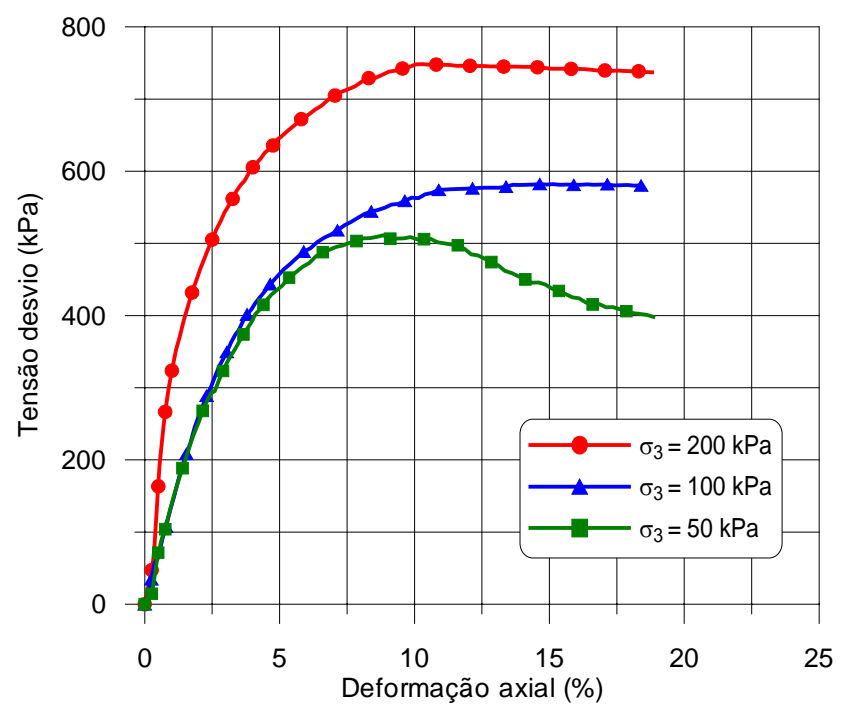

Figura 5.26. Curvas de Tensão desvio versus Deformação axial.

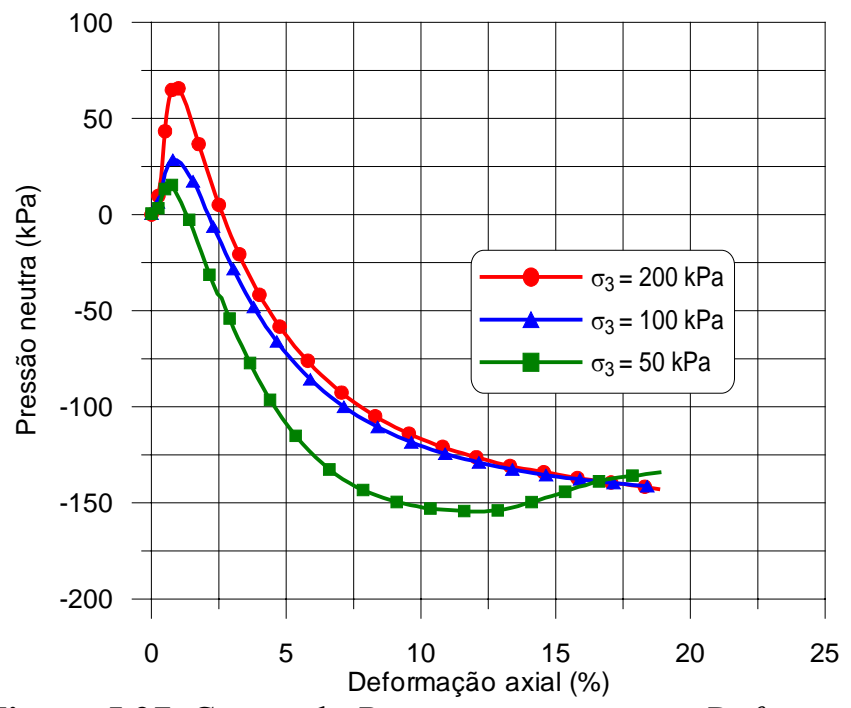

Figura 5.27. Curvas de Pressão neutra versus Deformação axial. 
- $\quad$ Mistura percolada com solução contaminante de $50 \mathrm{mg} / \mathrm{L}$

Nesta série os ensaios foram realizados em três corpos de prova percolados com solução contaminante de concentração $50 \mathrm{mg} / \mathrm{L}$. Os corpos de prova foram submetidos a tensões de confinamento de 50,100 e $200 \mathrm{kPa}$. Os resultados correspondentes à fase de adensamento são apresentados em curvas de Variação volumétrica (\%) versus $\bigvee_{t}$ (minutos) (Figura 5.28). Os resultados correspondentes à fase de cisalhamento são apresentados em curvas de Tensão desvio ( $\mathrm{kPa}$ ) versus Deformação axial (\%) (Figura 5.29) e de Pressão neutra ( $k P a)$ versus Deformação axial (\%) (Figura 5.30).

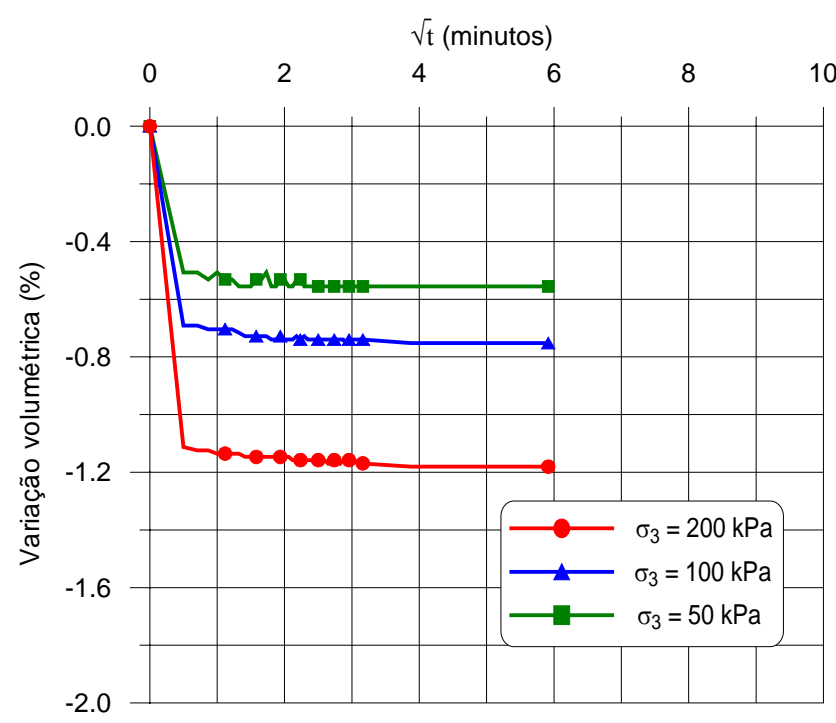

Figura 5.28. Curvas de Variação volumétrica (\%) versus $\downarrow t$, sendo o tempo em minutos.

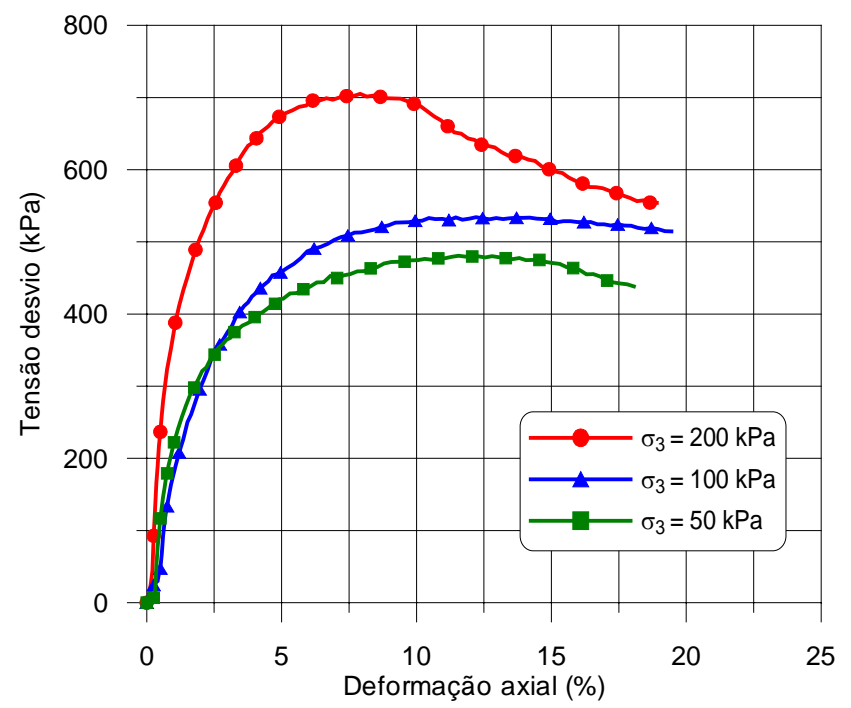

Figura 5.29. Curvas de Tensão desvio versus Deformação axial. 


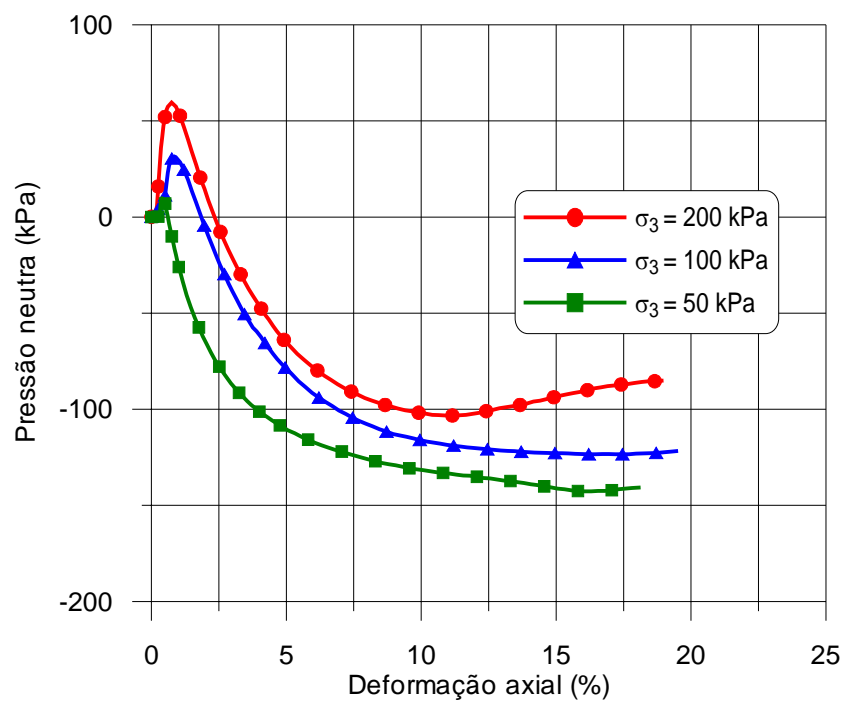

Figura 5.30. Curvas de Pressão neutra versus Deformação axial.

- $\quad$ Mistura percolada com solução contaminante de $300 \mathrm{mg} / \mathrm{L}$

Nesta série os ensaios foram realizados em três corpos de prova percolados com solução contaminante de concentração $300 \mathrm{mg} / \mathrm{L}$. Os corpos de prova foram submetidos a tensões de confinamento de 50,100 e $200 \mathrm{kPa}$. Os resultados correspondentes à fase de adensamento são apresentados em curvas de Variação volumétrica (\%) versus $\bigvee_{t}$ (minutos) (Figura 5.31). Os resultados correspondentes à fase de cisalhamento são apresentados em curvas de Tensão desvio (kPa) versus Deformação axial (\%) (Figura 5.32) e de Pressão neutra ( $k P a)$ versus Deformação axial (\%) (Figura 5.33).

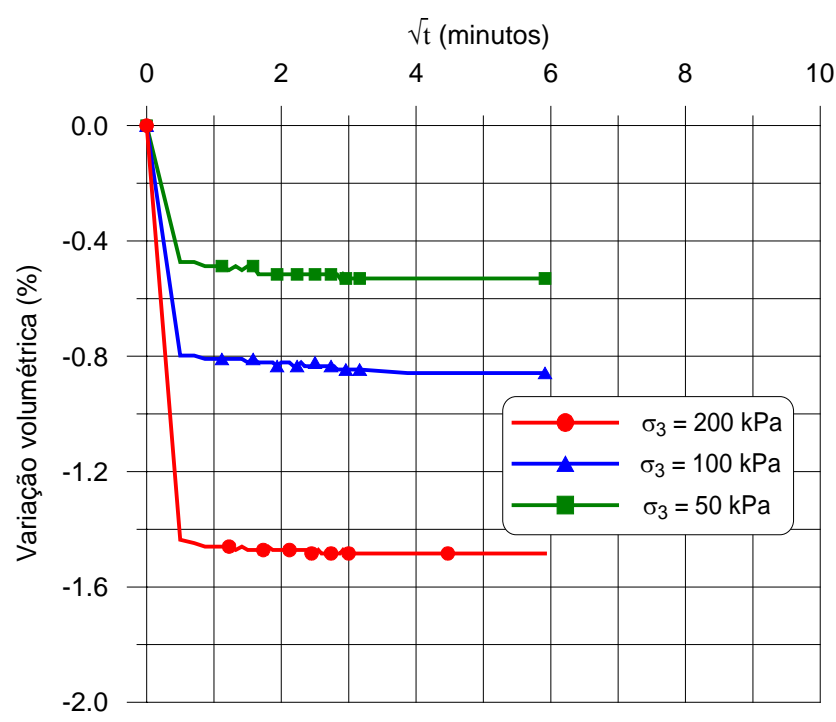

Figura 5.31. Curvas de Variação volumétrica (\%) versus 1 , sendo o tempo em minutos. 


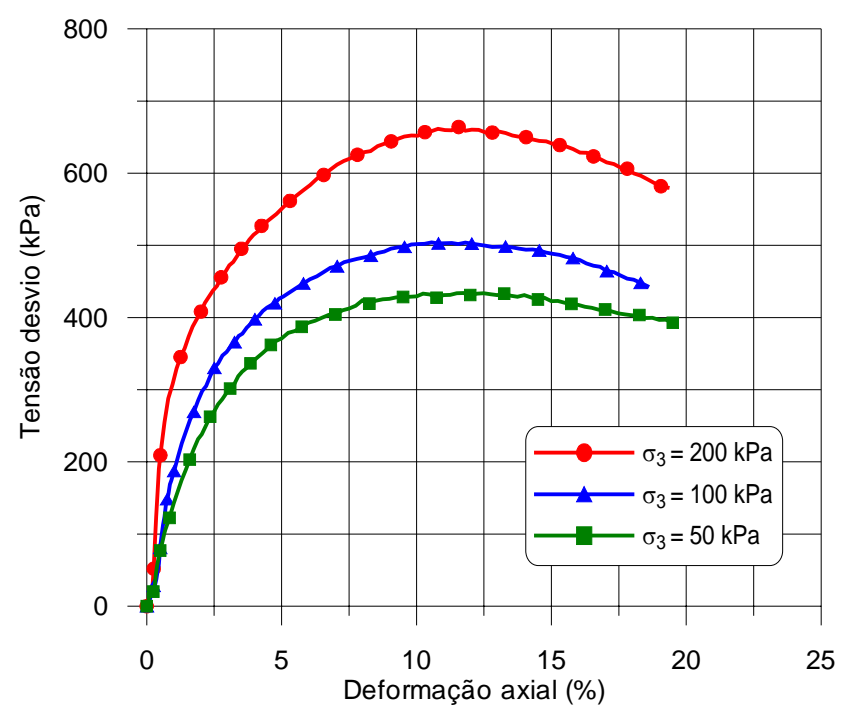

Figura 5.32. Curvas de Tensão desvio versus Deformação axial.

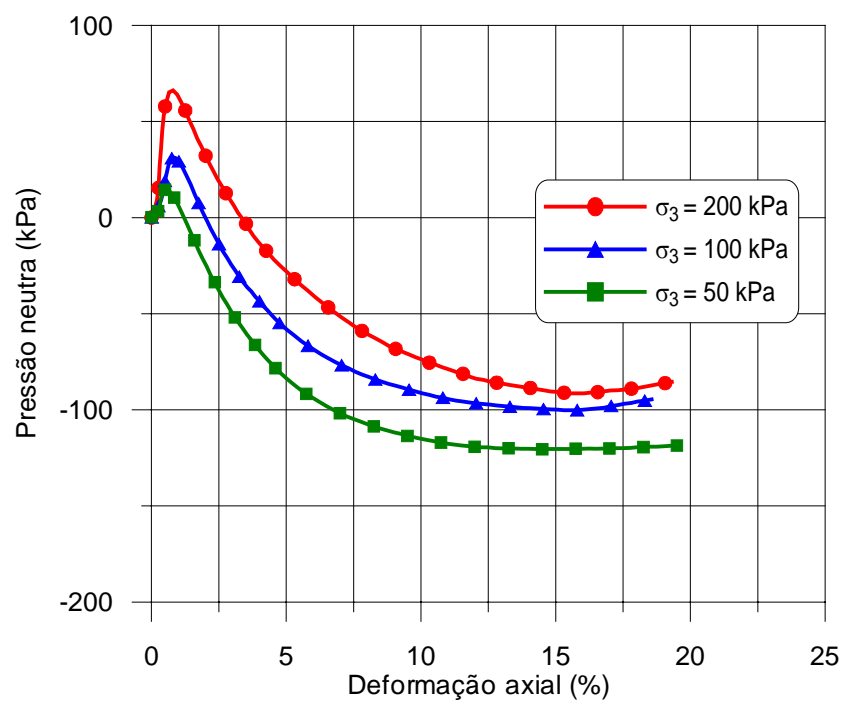

Figura 5.33. Curvas de Pressão neutra versus Deformação axial.

- $\quad$ Mistura percolada com solução contaminante de $600 \mathrm{mg} / \mathrm{L}$

Nesta série os ensaios foram realizados em três corpos de prova percolados com solução contaminante de concentração $600 \mathrm{mg} / \mathrm{L}$. Os corpos de prova foram submetidos a tensões de confinamento de 50,100 e $200 \mathrm{kPa}$. Os resultados correspondentes à fase de adensamento são apresentados em curvas de Variação volumétrica (\%) versus $V_{t}$ (minutos) (Figura 5.34). Os resultados correspondentes à fase de cisalhamento são apresentados em curvas de Tensão desvio ( $\mathrm{kPa}$ ) versus Deformação axial (\%) (Figura 5.35) e de Pressão neutra ( $\mathrm{kPa}$ ) versus Deformação axial (\%) (Figura 5.36). 


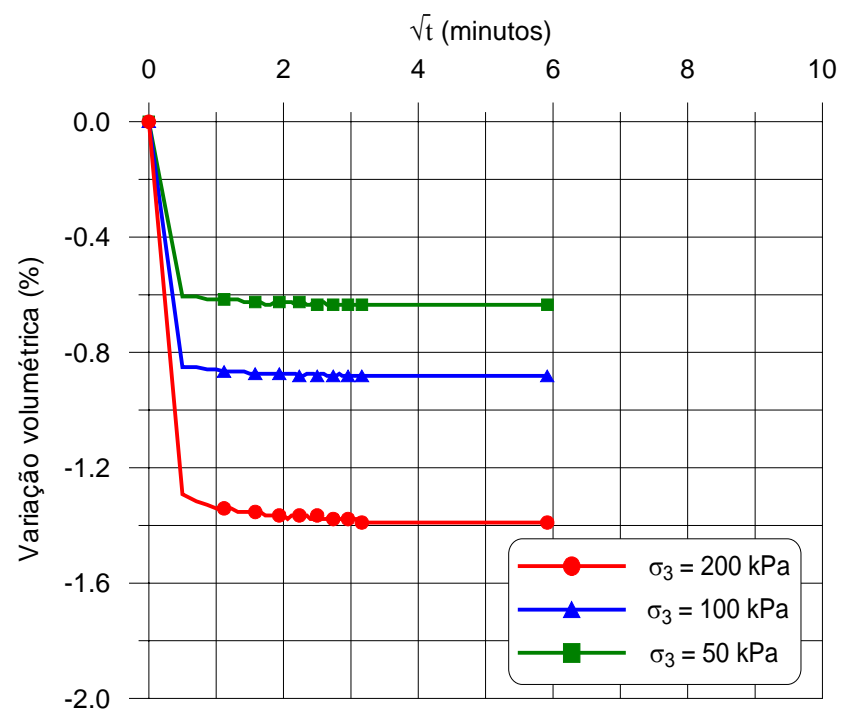

Figura 5.34. Curvas de Variação volumétrica (\%) versus $1 t$, sendo o tempo em minutos.

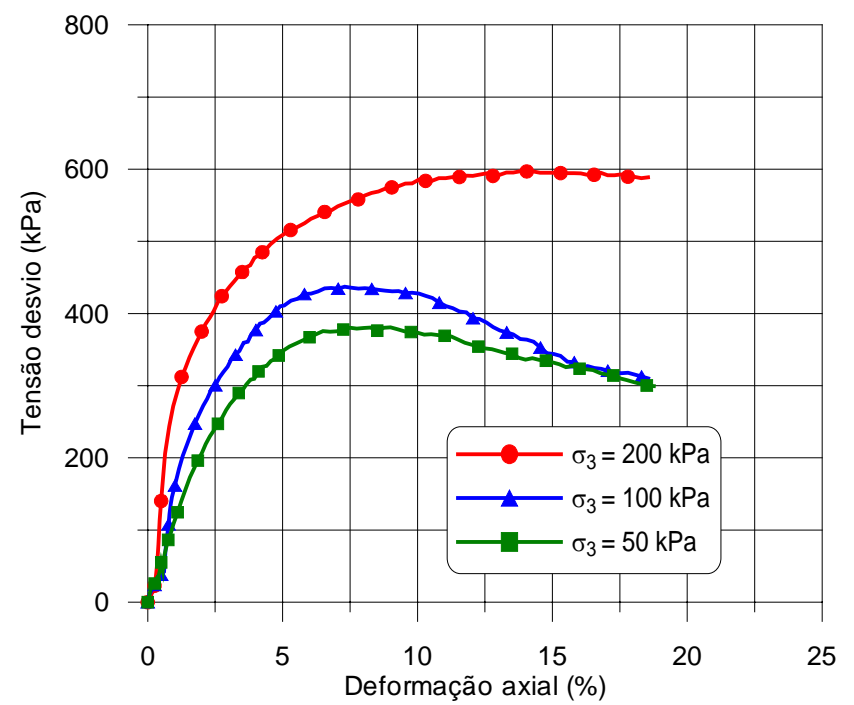

Figura 5.35. Curvas de Tensão desvio versus Deformação axial.

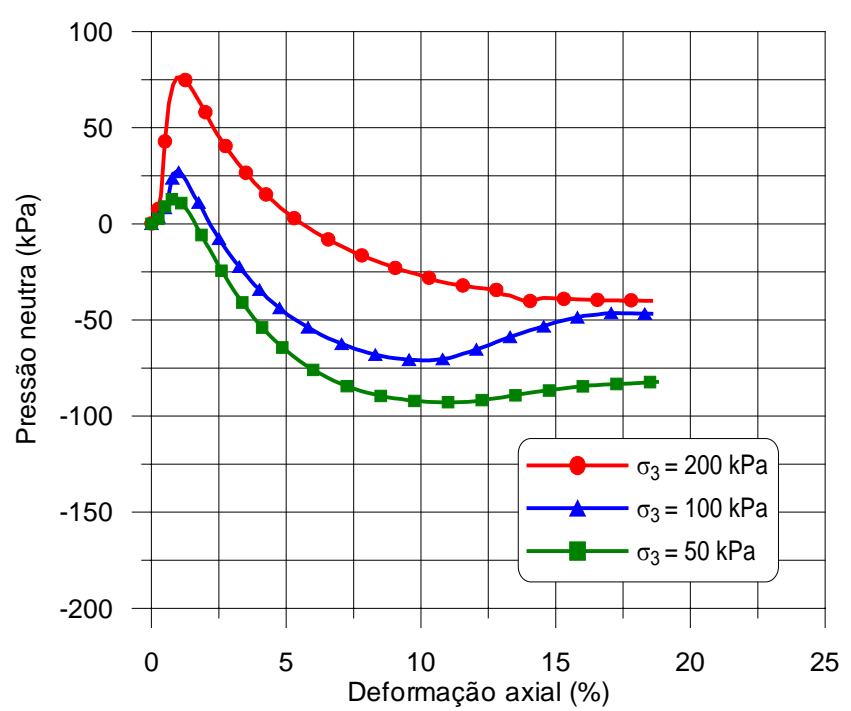

Figura 5.36. Curvas de Pressão neutra versus Deformação axial. 


\subsection{ENVOLTÓRIA DE RESISTÊNCIA}

Para uma representação mais clara, as envoltórias de resistência, são apresentadas em termos de trajetória de tensões. As envoltórias, para os três solos estudados, estão apresentadas nas Figuras 5.37, 5.38, 5.39, 5.40, 5.41 e 5.42. Para efeito de análise e comparação, para cada concentração de contaminante está plotado uma envoltória em termos de tensões totais ( $p \times q)$ e outra em tensões efetivas ( $\left.p^{\prime} \times q^{\prime}\right)$, onde:

$$
p=\frac{\sigma_{1}+\sigma_{3}}{2} ; q=\frac{\sigma_{1}-\sigma_{3}}{2} ; p^{\prime}=p-u ; q^{\prime}=q
$$

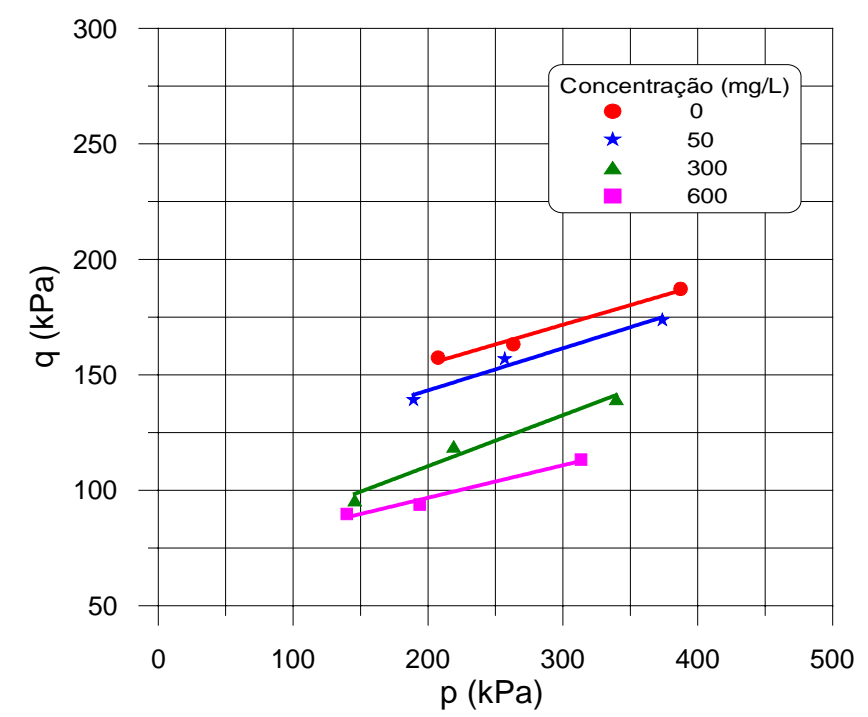

Figura 5.37. Envoltórias de resistência em termos de tensões totais - solo Serra Geral.

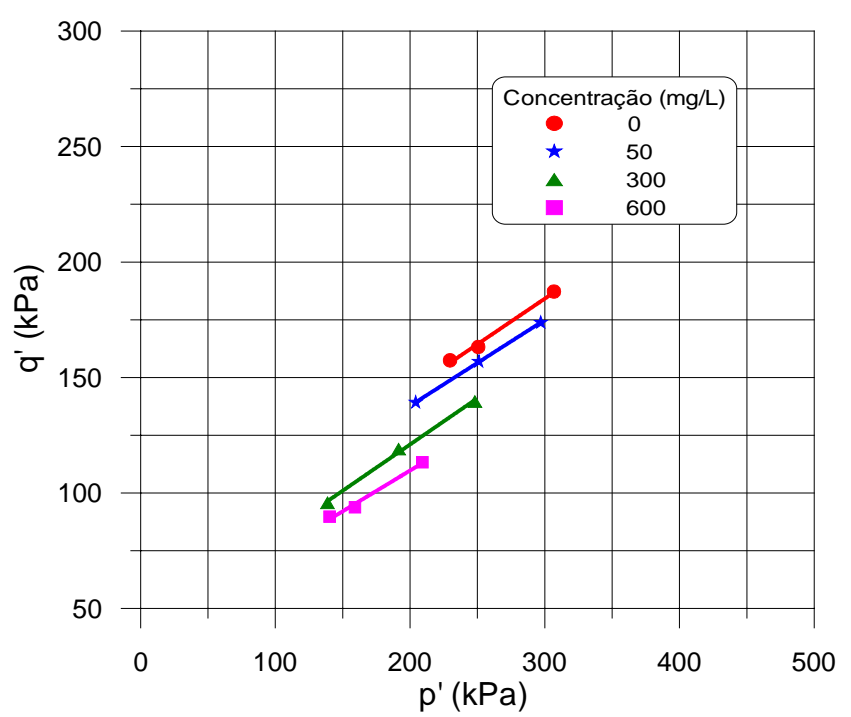

Figura 5.38. Envoltórias de resistência em termos de tensões efetivas - solo Serra Geral. 


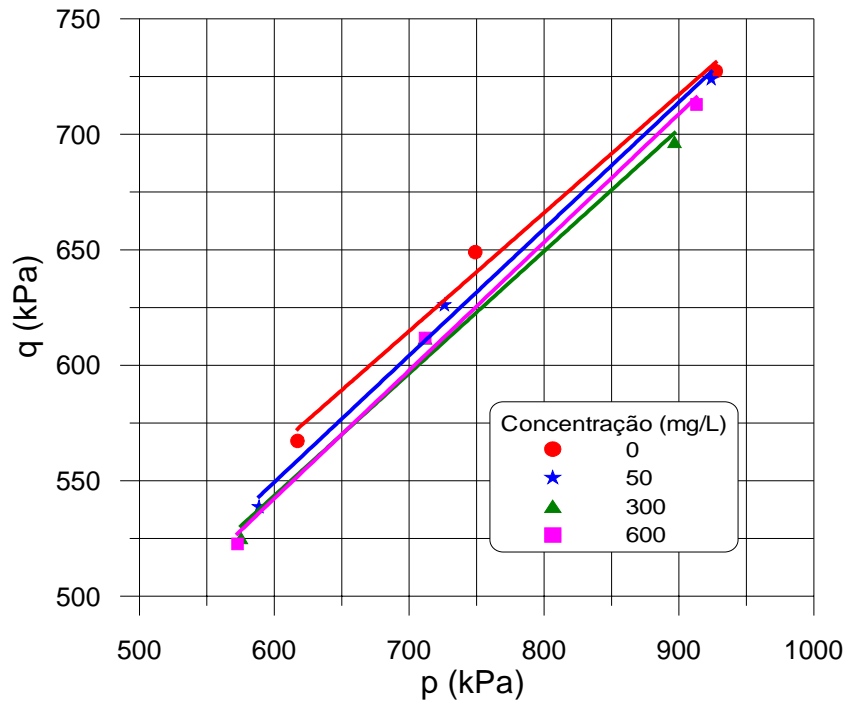

Figura 5.39. Envoltórias de resistência em termos de tensões totais - solo Botucatu.

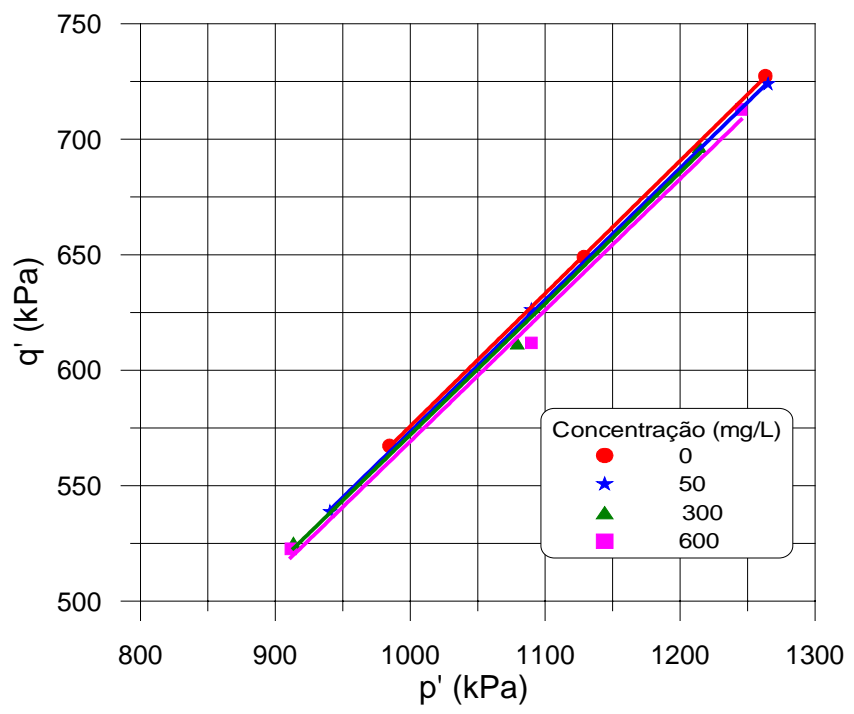

Figura 5.40. Envoltórias de resistência em termos de tensões efetivas - solo Botucatu.

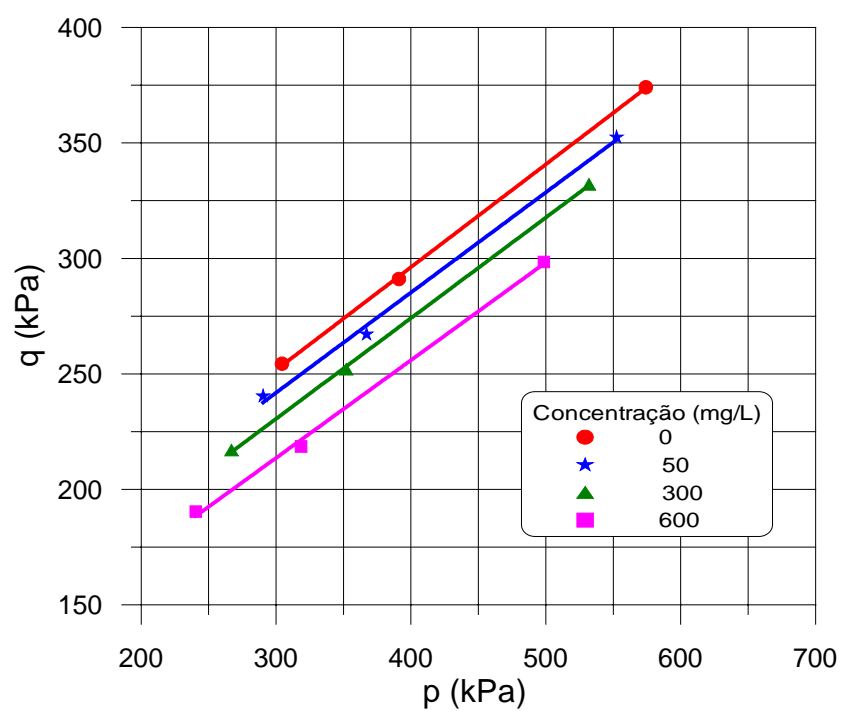

Figura 5.41. Envoltórias de resistência em termos de tensões totais - mistura. 


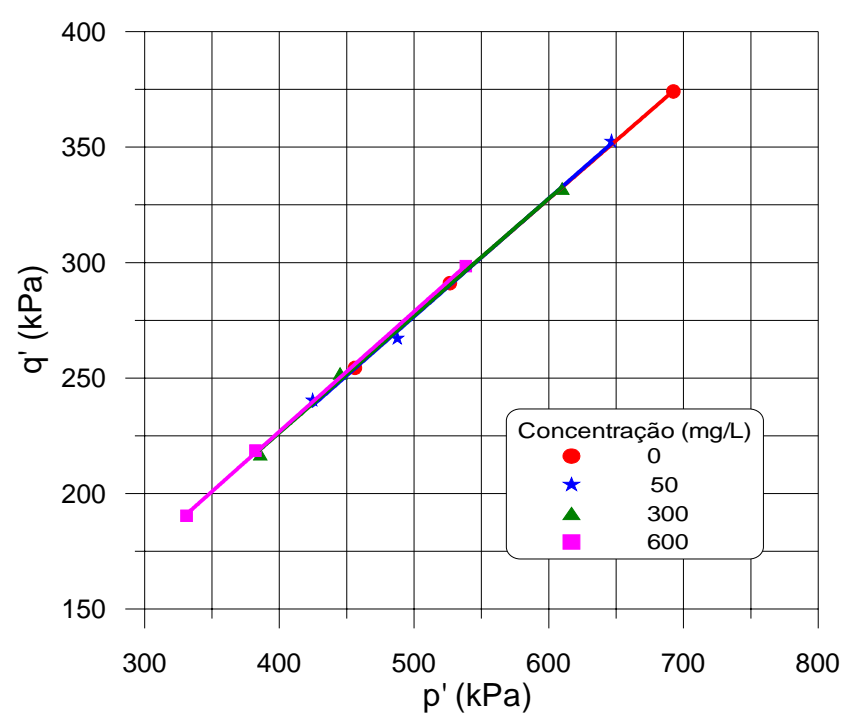

Figura 5.42. Envoltórias de resistência em termos de tensões efetivas - mistura. equação:

No plano $p-q$ a envoltória pode ser definida por uma reta determinada pela seguinte

onde:

$$
q=a+p \times \operatorname{tg} \alpha
$$

$a=$ intercepto da envoltória no plano $p-q$;

$\alpha=$ declividade da envoltória.

Os parâmetros de resistência, coesão total $(c)$ e efetiva $\left(c^{\prime}\right)$, e ângulo de atrito total $(\phi)$ e efetivo $\left(\phi^{\prime}\right)$, foram determinados a partir dos parâmetros $a$ e $\alpha$ da envoltória de trajetória de tensões . A Tabela 5.5 mostra, para cada nível de contaminação, os parâmetros de resistência obtidos para os três solos estudados.

Tabela 5.5. Parâmetros de resistência obtidos.

\begin{tabular}{|c|c|c|c|c|c|}
\hline \multirow{2}{*}{ Solo } & \multirow{2}{*}{$\begin{array}{c}\text { Concentração } \\
(\mathrm{mg} / \mathrm{L})\end{array}$} & \multicolumn{2}{|c|}{$\begin{array}{c}\text { Parâmetros } \\
\text { Totais }\end{array}$} & \multicolumn{2}{|c|}{$\begin{array}{c}\text { Parâmetros } \\
\text { Efetivos }\end{array}$} \\
\hline & & $\begin{array}{c}\mathrm{c} \\
(\mathrm{kPa})\end{array}$ & $\begin{array}{l}\phi \\
\left({ }^{\circ}\right)\end{array}$ & $\begin{array}{c}\mathrm{c}^{\prime} \\
(\mathrm{kPa})\end{array}$ & $\begin{array}{l}\phi \\
\left(^{\circ}\right)\end{array}$ \\
\hline \multirow{4}{*}{$\begin{array}{l}\text { Serra } \\
\text { Geral }\end{array}$} & 0 & 122,4 & 9,8 & 71,6 & 23,2 \\
\hline & 50 & 108,6 & 10,5 & 68,3 & 21,8 \\
\hline & 300 & 68,0 & 12,8 & 44,6 & 23,6 \\
\hline & 600 & 69,3 & 8,1 & 41,8 & 20,7 \\
\hline \multirow{4}{*}{ Botucatu } & 0 & 298,6 & 30,8 & 1,4 & 35,1 \\
\hline & 50 & 263,4 & 33,3 & 3,9 & 34,8 \\
\hline & 300 & 266,4 & 32,0 & 4,6 & 34,6 \\
\hline & 600 & 251,5 & 33,7 & 1,2 & 34,6 \\
\hline \multirow{4}{*}{ Mistura } & 0 & 131,9 & 26,4 & 28,2 & 30,4 \\
\hline & 50 & 124,0 & 25,7 & 24,3 & 30,8 \\
\hline & 300 & 111,0 & 25,8 & 27,2 & 30,5 \\
\hline & 600 & 95,6 & 25,0 & 22,4 & 31,3 \\
\hline
\end{tabular}




\subsection{ENSAIOS DE PERCOLAÇÃO EM COLUNAS}

\subsubsection{Condutividade Hidráulica}

Em geral, para os três solos estudados, a variação da condutividade hidráulica $(k)$ ao longo do processo de percolação com água deionizada manteve-se dentro de uma mesma faixa. Os valores médios de $k$ para os solos Serra Geral encontram-se entre $1,0 \times 10^{-9} \mathrm{~m} / \mathrm{s}$ e $3,0 \times 10^{-9} \mathrm{~m} / \mathrm{s}$, com exceção das três colunas que apresentaram valores na faixa de $9,0 \times 10^{-10} \mathrm{~m} / \mathrm{s}$, ou seja, muito próximo das demais. Para os solos Botucatu, os valores médios de $k$ situam-se entre $8,0 \times 10^{-8} \mathrm{~m} / \mathrm{s}$ e $1,0 \times 10^{-7} \mathrm{~m} / \mathrm{s}$, enquanto que para a mistura, os valores médios de $k$ se apresentam entre $9,0 \times 10^{-9} \mathrm{~m} / \mathrm{s}$ e $3,0 \times 10^{-8} \mathrm{~m} / \mathrm{s}$.

Durante a fase de percolação com as soluções contaminantes nas diferentes concentrações, os valores médios da condutividade hidráulica encontram-se próximos aos obtidos durante a fase de saturação com água. No entanto, para o solo Serra Geral e para a mistura, verificou-se um ligeiro aumento no valor médio de condutividade hidráulica durante a percolação das soluções contaminantes. Para o solo Botucatu, algumas colunas apresentaram valores médios de condutividade hidráulica superiores, enquanto outras, valores inferiores aos valores obtidos durante a percolação com água.

Embora não exista um consenso entre as agências reguladoras, a Cetesb (1993) especifica que a barreira impermeável constituída por solo compactado, deve apresentar uma condutividade hidráulica de no máximo $10^{-9} \mathrm{~m} / \mathrm{s}$. Assim, verificou-se que o solo Serra Geral atende a esta exigência, e a mistura se encontra em uma faixa muito próxima, podendo, dependendo da periculosidade do resíduo disposto, ser utilizada para fins de projeto. O solo Botucatu não atende à essa especificação, não podendo portanto ser utilizado isoladamente.

\subsubsection{Curvas de Chegada}

De forma genérica, as curvas de chegada determinadas a partir dos ensaios de percolação em colunas, mostraram que as concentrações iônicas finais tanto do $\mathrm{Cu}^{+2}$ quanto do $C l^{-1}$, se igualaram às concentrações originais da solução contaminante $\left(C / C_{0}=1,0\right)$. A 
igualdade entre as concentrações foi importante para confirmar o final do processo de atenuação do contaminante pelo solo e permitir a avaliação do efeito da contaminação por cloreto de cobre na resistência ao cisalhamento dos solos.

Ao analisar as curvas de chegada apresentadas no Apêndice A, é possível tecer alguns comentários:

- Verificou-se que as curvas de chegada construídas para os íons $\mathrm{Cu}^{+2}$ e $\mathrm{Cl}^{-1}$ apresentam comportamentos individuais e padrões bem definidos entre si;

- Para as amostras 04, 05 e 06 do solo Serra Geral, percoladas com contaminante na concentração de $50 \mathrm{mg} / \mathrm{L}$, representadas pelas curvas de chegada das Figuras A1, A2 e A3, respectivamente, ficou bem evidenciado o atraso na "saída do contaminante". Esta situação pode estar relacionada à menor concentração da solução contaminante, à baixa condutividade hidráulica do solo Serra Geral e principalmente à maior quantidade de partículas argilosas existentes neste solo, aumentando-se assim, a interação química entre o solo e o contaminante.

- Analisando-se as amostras de solos individualmente, observou-se que o íon $\mathrm{Cu}^{+2}$ é preferencialmente retido pelas amostras, em relação aos íons $\mathrm{Cl}^{-1}$. Porém, a capacidade de atenuação destes íons ocorreu de forma mais rápida à medida que se aumentou a concentração do contaminante que percolou através das amostras de solo.

- Ao comparar os três solos estudados, verificou-se que o volume percolado de contaminante para a completa adsorção, conforme apresentado nas Tabelas 5.2, 5.3 e 5.4, foi maior para o solo Serra Geral, em seguida para a mistura e por último para o solo Botucatu. Isso mostrou que a capacidade de atenuação do solo Serra Geral foi maior que àquela apresentada pelos demais solos. No caso do solo Botucatu, praticamente não houve alteração do volume percolado $\left(V_{p}\right)$, para as concentrações de $300 \mathrm{mg} / \mathrm{L}$ e $600 \mathrm{mg} / \mathrm{L}$.

\subsection{ENSAIOS TRIAXIAIS}

Ao serem analisadas as curvas de Variação volumétrica versus $V_{t}$, de Tensão desvio versus Deformação axial e de Pressão neutra versus Deformação axial, apresentadas para os três solos no Capítulo 5, podem ser feitas algumas considerações, tais como: 
De maneira geral, ao comparar às curvas de adensamento dos três solos estudados, pode-se dizer, que se apresentam de forma consistente, ou seja, o solo Serra Geral sofreu o maior adensamento, o solo Botucatu o menor e a mistura apresentou comportamento intermediário.

Partindo-se para as análises individuais, observou-se que para os corpos de prova do solo Serra Geral, percolados com as soluções contaminantes de $300 \mathrm{mg} / \mathrm{L}$ (Figura 5.7) e $600 \mathrm{mg} / \mathrm{L}$ (Figura 5.10) e confinados com 100 e $200 \mathrm{kPa}$, ocorreu uma maior variação volumétrica (maior adensamento) ao longo do tempo. Tal comportamento serviu como indicativo das possíveis alterações da estrutura do solo, provocadas pela interação química entre o solo e o contaminante. Para o solo Botucatu, pode-se dizer que a variação volumétrica, em termos comparativos em relação as concentrações de contaminante, foi mínima. Os valores de variação volumétrica para a mistura, apresentaram-se em uma faixa intermediária aos obtidos para os solos Serra Geral e Botucatu, com exceção feita para os corpos de prova confinados com $200 \mathrm{kPa}$ (nas quatro situações de percolação), que apresentaram valores muito próximos aos obtidos para o solo Serra Geral ensaiados com esta mesma tensão confinante. Sendo assim, os solos percolados com 300 mg/L (Figura 5.31) e $600 \mathrm{mg} / \mathrm{L}$ (Figura 5.34), em termos comparativos, sofreram maior adensamento que os percolados com 0 (Figura 5.25) e $50 \mathrm{mg} / \mathrm{L}$ (Figura 5.28).

Em geral, para cada solo, não há uma mudança significativa (curvas similares) no comportamento Tensão desvio-Deformação axial e Pressão neutra-Deformação axial entre as amostras contaminadas e as isentas de contaminante para um mesmo nível de tensão de confinamento. Porém, as diferenças se manifestam nas máximas tensões desvio, apresentando maiores variações para o solo Serra Geral.

As Figuras 6.1, 6.2 e 6.3 apresentam a influência do cloreto de cobre na resistência dos solos estudados, por meio de gráficos de tensão desvio $\left(\sigma_{1}-\sigma_{3}\right)$ na ruptura versus concentrações de contaminante. Cada figura mostra, para um determinado nível de tensão de confinamento, a variação da resistência com as diferentes concentrações de contaminantes, para cada um dos três solos. 


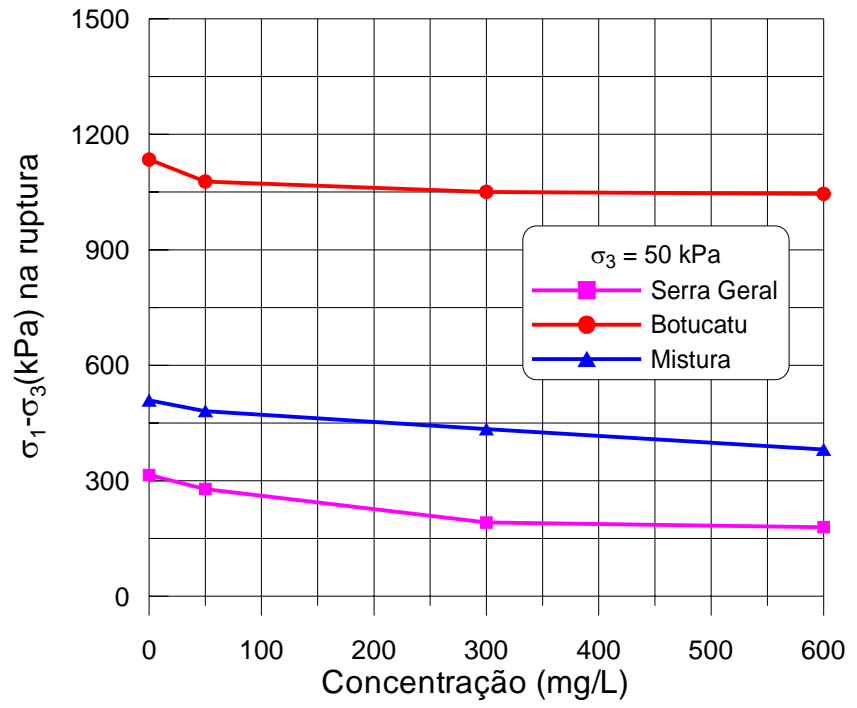

Figura 6.1. Tensão desvio na ruptura em função da concentração do contaminante para os três solos, confinados com $50 \mathrm{kPa}$.

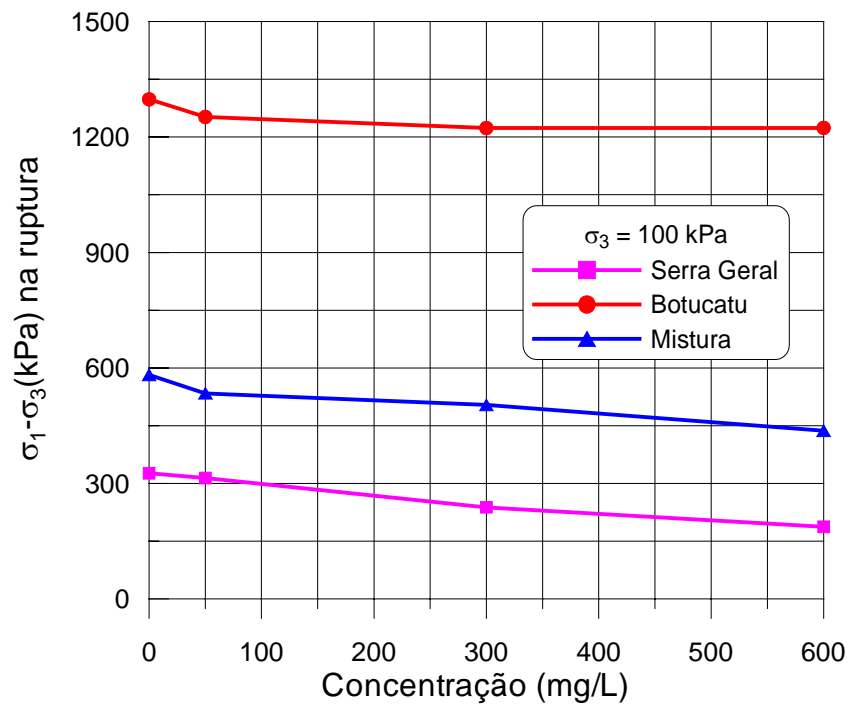

Figura 6.2. Tensão desvio na ruptura em função da concentração do contaminante para os três solos, confinados com $100 \mathrm{kPa}$. 


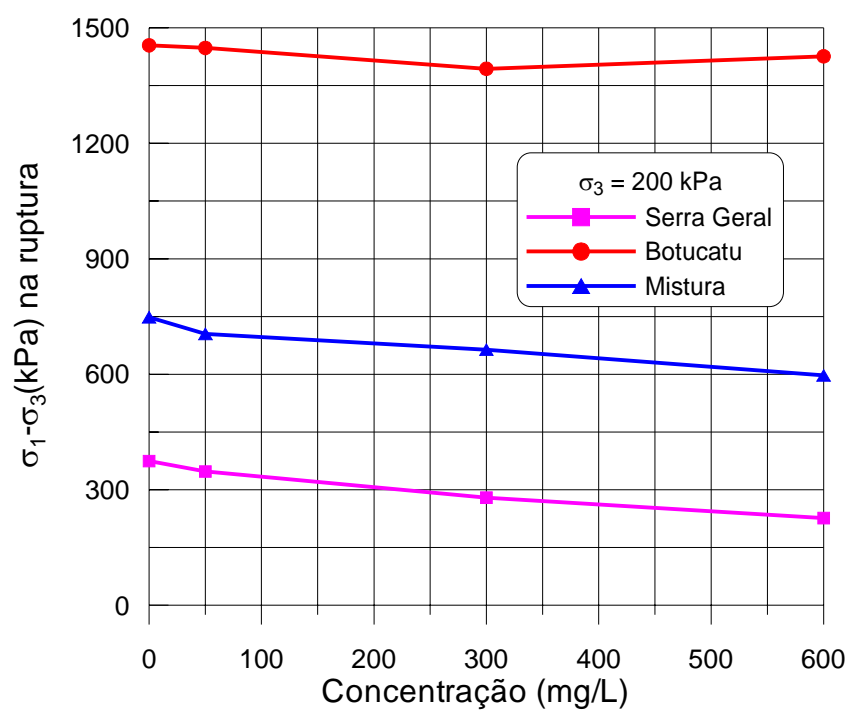

Figura 6.3. Tensão desvio na ruptura em função da concentração do contaminante para os três solos, confinados com $200 \mathrm{kPa}$.

Verifica-se que os solos arenosos (Botucatu) apresentam uma maior resistência em relação aos demais. A mistura, como era de se esperar, apresentou uma resistência superior à do solo argiloso (Serra Geral).

As Figuras 6.4, 6.5 e 6.6 mostram, para cada tensão confinante, a relação entre a tensão desvio na ruptura $\left(\sigma_{1}-\sigma_{3 \operatorname{máx}}\right)$ em função da concentração do contaminante para os três solos em estudo. No entanto, para efeito de comparação, os valores de tensão desvio na ruptura estão apresentados em termos porcentuais dos correspondentes valores dos solos isentos de contaminante. Isto é, o solo isento de contaminante, serviu como valor de referência $(100 \%)$ para as diferentes tensões de confinamento.

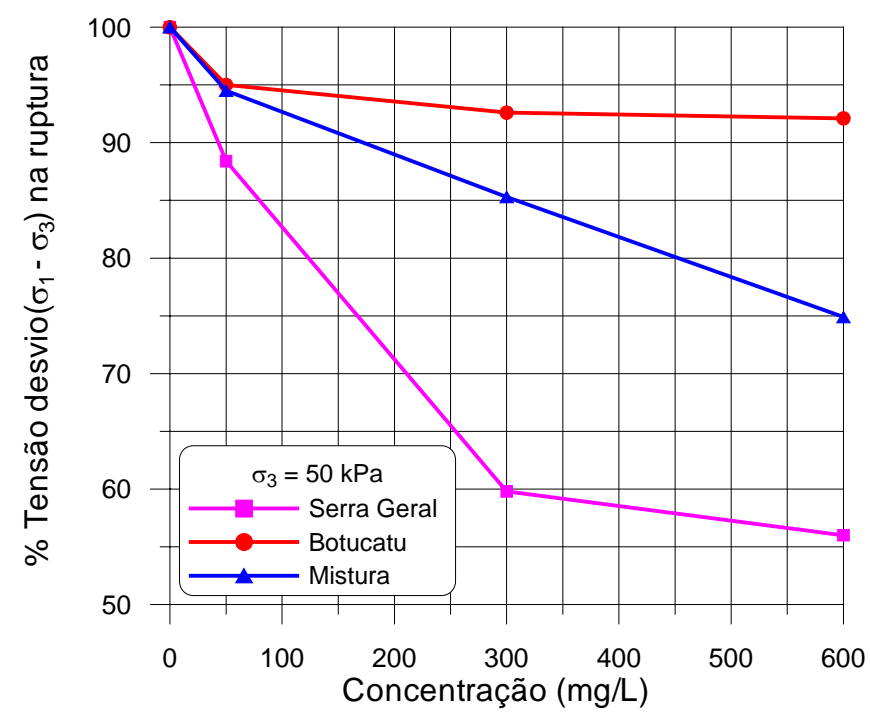

Figura 6.4. Valores relativos da tensão desvio de ruptura em função da concentração do contaminante, para os três solos, confinados com $50 \mathrm{kPa}$. 


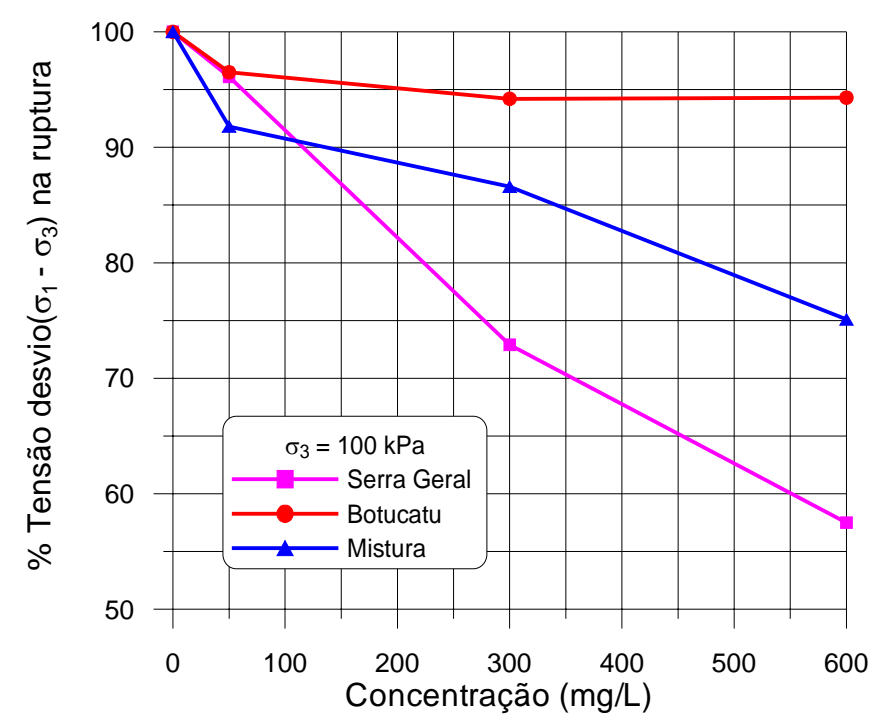

Figura 6.5. Valores relativos da tensão desvio de ruptura em função da concentração do contaminante, para os três solos, confinados com $100 \mathrm{kPa}$.

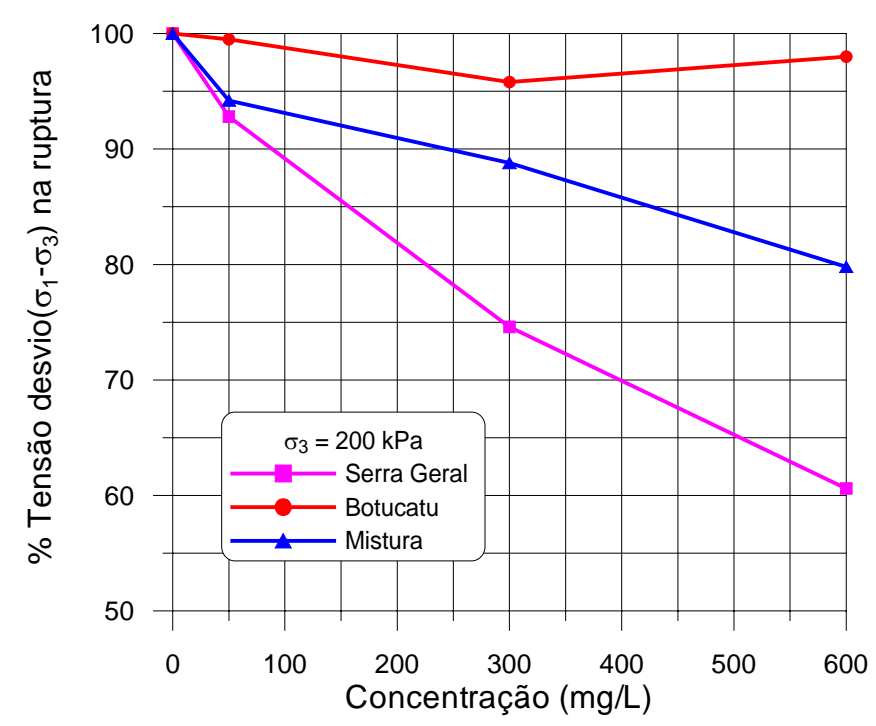

Figura 6.6. Valores relativos da tensão desvio de ruptura em função da concentração do contaminante, para os três solos, confinados com $200 \mathrm{kPa}$.

Observa-se, através das Figuras 6.4, 6.5 e 6.6, uma mesma tendência para os três solos analisados, para cada tensão confinante. Os solos podem ser agrupados em três faixas distintas: os que sofreram maior, menor e intermediária influência do contaminante, que correspondem ao solo Serra Geral, ao solo Botucatu e a mistura, respectivamente.

Outro aspecto importante é analisar o efeito da tensão de confinamento aplicada no corpo de prova. A partir dos resultados apresentados nas Figuras 6.4, 6.5 e 6.6, verificouse que existe uma relação entre a tensão desvio na ruptura e a concentração de contaminante, para cada tensão de confinamento. Nota-se que a influência da contaminação na resistência ao cisalhamento dos solos foi mais significativa para maiores concentrações de contaminante 
e menores tensões de confinamento. $\mathrm{O}$ efeito da tensão de confinamento pode ser explicado pelo fato de que ao aumentar a tensão de confinamento, a influência da contaminação passa a ser mascarada, sendo, portanto mais facilmente verificada para as menores tensões confinantes.

Pode-se observar ainda que o efeito da contaminação foi mais pronunciado nos solos argilosos Serra Geral. À medida em que se aumentou a concentração do contaminante, a tensão desviadora de ruptura diminuiu, chegando a uma redução máxima de $43,0 \%$ para tensão confinante de $50 \mathrm{kPa}$ e concentração de $600 \mathrm{mg} / \mathrm{L}$. Os solos arenosos Botucatu sofreram pouca influência, estando todos os valores dentro de uma mesma faixa de variação. A redução máxima apresentada foi de 7,9\% para tensão confinante de $50 \mathrm{kPa}$ e concentração de $600 \mathrm{mg} / \mathrm{L}$. A mistura também sofreu maiores reduções com o aumento da concentração, mas de magnitudes intermediárias entre os dois solos já mencionados, chegando a uma redução máxima de $25,1 \%$ para a tensão de confinamento de $50 \mathrm{kPa}$ e concentração de 600 $\mathrm{mg} / \mathrm{L}$.

\subsubsection{Parâmetros de Resistência em Função da Concentração}

As envoltórias totais e efetivas apresentadas nas Figuras 5.37 a 5.42 confirmaram a maior influência do contaminante no solo Serra Geral. Para este solo, observou-se que as envoltórias encontram-se mais espaçadas, ou seja, há maiores variações nos interceptos de coesão, ao se comparar aos demais solos. Notou-se ainda, que para todos os solos, existe um certo paralelismo entre as envoltórias apresentadas, indicando pouca variação no ângulo de atrito.

Para melhor analisar os parâmetros de resistência $(c$ e $\phi)$ totais e efetivos, mostrados na Tabela 5.4, apresentam-se as Figuras 6.7, 6.8, 6.9 e 6.10. Estas Figuras ilustram respectivamente, a variação da coesão total e efetiva e ângulo de atrito total e efetivo em função da concentração de contaminante, para os três solos em análise. 


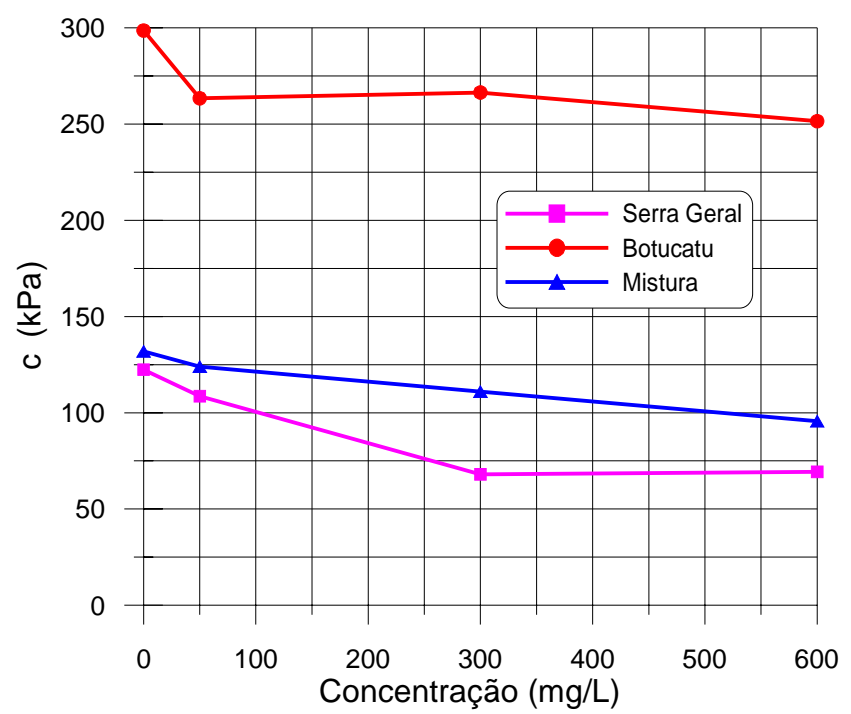

Figura 6.7. Variação da coesão total com a concentração do contaminante.

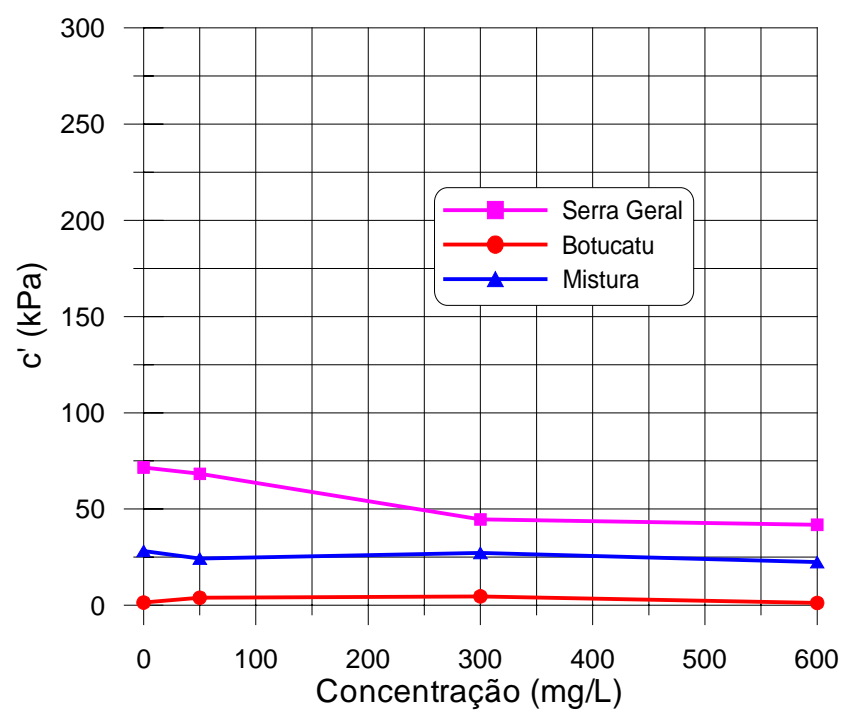

Figura 6.8. Variação da coesão efetiva com a concentração do contaminante.

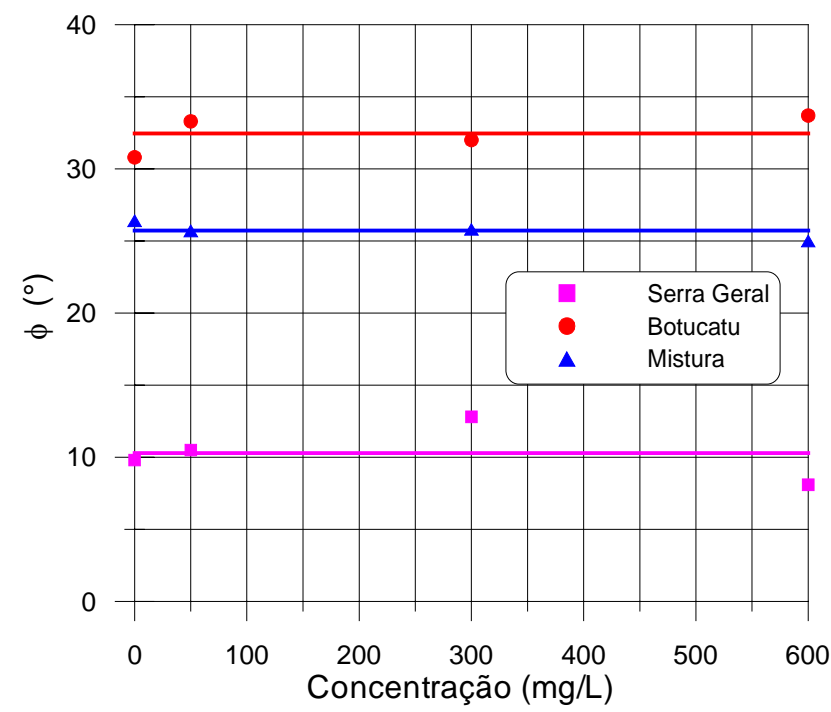

Figura 6.9. Variação do ângulo de atrito total com a concentração do contaminante. 


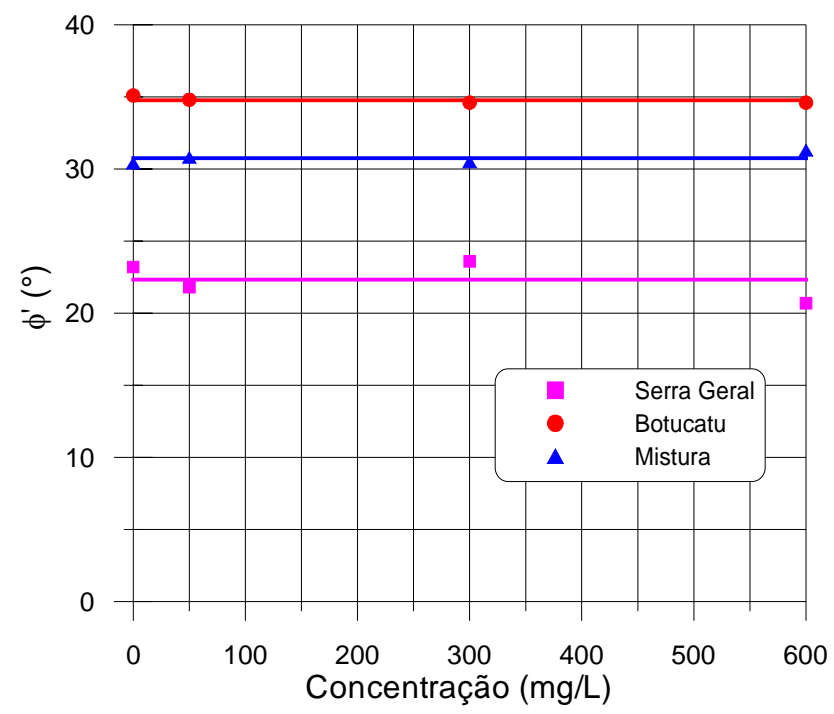

Figura 6.10. Variação do ângulo de atrito efetivo com a concentração do contaminante.

Para as amostras de solo Serra Geral, a coesão total e efetiva sofreram decréscimo com o aumento da concentração da solução contaminante. Ao analisar estes parâmetros, em relação aos solos percolados somente com água destilada, verificou-se que a coesão total sofreu redução de 43,4\%, passando de $122,4 \mathrm{kPa}$ para $69,3 \mathrm{kPa}$, para o corpo de prova percolado com solução contaminante na concentração de $300 \mathrm{mg} / \mathrm{L}$. Para a coesão efetiva, a redução foi de 41,6\%, passando de 71,6 kPa para 41,8 kPa, para a concentração de $600 \mathrm{mg} / \mathrm{L}$. No caso da mistura, para concentração de $600 \mathrm{mg} / \mathrm{L}$, houve redução de 27,5\% na coesão total, passando de $131,9 \mathrm{kPa}$ para $95,6 \mathrm{kPa}$, enquanto que a coesão efetiva sofreu redução de 20,6\%, passando de 28,2 kPa para 22,4 kPa.

O solo Botucatu foi pouco influenciado pelo contaminante, apresentando redução em torno de $15,7 \%$ na coesão total, para a concentração de $600 \mathrm{mg} / \mathrm{L}$, e praticamente nenhuma influência na coesão efetiva, estando os valores dentro de uma mesma faixa típica para solos arenosos, ou seja, próximos de zero. A baixa influência do contaminante no solo Botucatu confirma os valores obtidos por Izzo (2003), em que as reduções de resistência foram pouco significativas para este solo, ficando mais evidenciadas para menores tensões confinantes.

Para os três solos analisados, o ângulo de atrito total e efetivo foi pouco influenciado pelo contaminante. Houve uma variação máxima de $3^{\circ}$ (ângulo de atrito total) para o solo Serra Geral de concentração de $300 \mathrm{mg} / \mathrm{L}$, e de 2,9 (ângulo de atrito total) para . do solo Botucatu de concentração de $600 \mathrm{mg} / \mathrm{L}$. Todas as variações são referentes ao solo isento de contaminante. A baixa variação no ângulo de atrito, provocada pela contaminação, também foi constatada no trabalho de Al - Sanad e Ismael (1995), que ao realizar ensaio triaxial do tipo adensado e não drenado $(\mathrm{CU})$ em solos arenosos contaminados com óleo $(6 \%$ 
em relação a massa seca), constatou uma pequena redução da resistência, representando aproximadamente $2^{\circ}$ no ângulo de atrito.

Ao analisar os parâmetros efetivos de resistência, confirmou-se que a parcela de resistência, devido à coesão, é mais significativa para os solos que apresentam maiores quantidades de finos (argila), na ordem: solo Serra Geral, mistura e solo Botucatu. A parcela relativa ao atrito entre partículas é mais pronunciada em solos granulares (arenosos), na ordem: solo Botucatu, mistura e solo Serra Geral.

\subsubsection{Deformabilidade}

O módulo de deformabilidade não drenado é de difícil determinação. Lambe e Whitman (1979) comentam que o módulo não drenado é muito sensível ao nível de tensão e que muitos fatores podem afetá-lo, entre os quais, a magnitude do carregamento, tempo de adensamento, tensão principal intermediária $\left(\sigma_{2}\right)$ e especialmente, imperfeições na amostra. Estes fatores exercem maior influência na porção inicial da curva Tensão desvio Deformação axial do que na tensão de pico, afetando, portanto, mais o módulo de deformabilidade do que a resistência.

Embora a determinação do módulo de deformabilidade não fizesse parte dos objetivos deste trabalho, aproveitaram-se os resultados dos ensaios triaxiais realizados para determinar este módulo secante em relação a $50 \%$ da tensão de ruptura $\left(E_{50}\right)$. As Tabelas 5.6, 5.7 e 5.8 apresentam os valores obtidos para os três solos estudados nas diferentes concentrações $(0,50,300$ e $600 \mathrm{mg} / \mathrm{L})$. As diferenças são relativas ao solo percolado somente com água destilada $(\mathrm{C}=0)$.

Tabela 5.6 - Módulo de deformabilidade secante a 50\% $\left(E_{50}\right)$ para solo Serra Geral.

\begin{tabular}{|c|c|c|c|c|c|c|c|}
\hline \multirow{2}{*}{$\begin{array}{c}\sigma_{3} \\
(\mathbf{k P a})\end{array}$} & $\begin{array}{c}\text { E50 } \\
(\mathrm{MPa})\end{array}$ & $\begin{array}{c}\text { E50 } \\
(\mathrm{MPa})\end{array}$ & \multirow{2}{*}{$\begin{array}{c}\text { Diferença } \\
\text { relativa } \\
\text { (\%) }\end{array}$} & \multirow{2}{*}{$\begin{array}{c}\begin{array}{c}\text { E50 } \\
(\mathrm{MPa})\end{array} \\
\mathrm{C}=300 \\
(\mathrm{mg} / \mathrm{L})\end{array}$} & \multirow{2}{*}{$\begin{array}{c}\text { Diferença } \\
\text { relativa } \\
\text { (\%) }\end{array}$} & \multirow{2}{*}{$\begin{array}{c}\begin{array}{c}\text { E50 } \\
(\mathrm{MPa})\end{array} \\
\mathrm{C}=600 \\
(\mathrm{mg} / \mathrm{L})\end{array}$} & \multirow{2}{*}{$\begin{array}{c}\text { Diferença } \\
\text { relativa } \\
(\%)\end{array}$} \\
\hline & $\mathrm{C}=\mathbf{0}$ & $\begin{array}{c}\mathrm{C}=\mathbf{5 0} \\
(\mathrm{mg} / \mathrm{L})\end{array}$ & & & & & \\
\hline 50 & 40,54 & 45,18 & 11 & 27,56 & -32 & 12,18 & -7 \\
\hline 100 & 67,67 & 24,76 & $-63,4$ & 12,67 & 29,8 & 56,21 & -17 \\
\hline 200 & 26,92 & 106,13 & 294 & 85,82 & 219 & 124,3 & 362 \\
\hline
\end{tabular}

Tabela 5.7 - Módulo de deformabilidade secante a 50\% $\left(E_{50}\right)$ para solo Botucatu.

\begin{tabular}{|c|c|c|c|c|c|c|c|}
\hline \multirow{2}{*}{$\begin{array}{c}\sigma_{3} \\
(\mathrm{kPa})\end{array}$} & $\begin{array}{c}\text { E50 } \\
(\mathrm{MPa})\end{array}$ & $\begin{array}{c}\text { E50 } \\
(\mathrm{MPa})\end{array}$ & \multirow{2}{*}{$\begin{array}{c}\text { Diferença } \\
\text { relativa } \\
(\%)\end{array}$} & \multirow{2}{*}{$\begin{array}{c}\begin{array}{c}\text { E50 } \\
(\mathrm{MPa})\end{array} \\
\mathrm{C}=\mathbf{3 0 0} \\
(\mathrm{mg} / \mathrm{L})\end{array}$} & \multirow{2}{*}{$\begin{array}{c}\text { Diferença } \\
\text { relativa } \\
\text { (\%) }\end{array}$} & \multirow{2}{*}{$\begin{array}{c}\begin{array}{c}\text { E50 } \\
(\mathrm{MPa})\end{array} \\
\mathrm{C}=600 \\
(\mathrm{mg} / \mathrm{L})\end{array}$} & \multirow{2}{*}{$\begin{array}{c}\text { Diferença } \\
\text { relativa } \\
(\%)\end{array}$} \\
\hline & $\mathrm{C}=\mathbf{0}$ & $\begin{array}{c}\mathrm{C}=50 \\
(\mathrm{mg} / \mathrm{L})\end{array}$ & & & & & \\
\hline 50 & 26 & 26,67 & & 24,34 & & 20,71 & \\
\hline 100 & 34,34 & 32,95 & & 30,87 & & 32,39 & $-5,7$ \\
\hline 200 & 57,62 & 41,28 & $-28,3$ & 34,98 & $-39,3$ & 42,69 & $-25,9$ \\
\hline
\end{tabular}


Tabela 5.8 - Módulo de deformabilidade secante a 50\% $\left(E_{50}\right)$ para a mistura 20\%-80\%.

\begin{tabular}{|c|c|c|c|c|c|c|c|}
\hline \multirow{2}{*}{$\begin{array}{c}\sigma_{3} \\
(\mathrm{kPa})\end{array}$} & $\begin{array}{c}\text { E50 } \\
\text { (MPa) }\end{array}$ & $\begin{array}{c}\text { E50 } \\
\text { (MPa) }\end{array}$ & \multirow{2}{*}{$\begin{array}{c}\text { Diferença } \\
\text { relativa } \\
(\%)\end{array}$} & \multirow{2}{*}{$\begin{array}{c}\text { E50 } \\
\text { (MPa) }\end{array}$} & \multirow{2}{*}{$\begin{array}{c}\text { Diferença } \\
\text { relativa } \\
(\%)\end{array}$} & \multirow{2}{*}{$\begin{array}{c}\begin{array}{c}\text { E50 } \\
(\mathrm{MPa})\end{array} \\
\mathrm{C}=600 \\
(\mathrm{mg} / \mathrm{L})\end{array}$} & \multirow{2}{*}{$\begin{array}{c}\text { Diferença } \\
\text { relativa } \\
(\%)\end{array}$} \\
\hline & $C=0$ & $\begin{array}{c}\mathrm{C}=50 \\
(\mathrm{mg} / \mathrm{L})\end{array}$ & & & & & \\
\hline 50 & 12,58 & 20,72 & & 12,43 & & 10,69 & -1 \\
\hline 100 & 12,56 & 15,71 & 25,1 & 16,31 & 29,8 & 15,07 & 20 \\
\hline 200 & 28,28 & 39,42 & 39,4 & 29,3 & 3,6 & 26,17 & $-7,5$ \\
\hline
\end{tabular}

De um modo geral, as diferenças relativas no módulo de deformabilidade apresentadas nas Tabelas 5.6, 5.7 e 5.8 e melhor representados pelas Figuras 6.11, 6.12 e 6.13 , oscilam entre positivas e negativas, ou seja, de maior ou menor rigidez, dificultando a análise sobre a influência da contaminação neste parâmetro, mas, alguns valores chamaram a atenção. As amostras de solo Serra Geral confinadas com $200 \mathrm{kPa}$, apresentaram aumentos substanciais no módulo de deformabilidade, situando-se entre $219 \%$ e $362 \%$. Tal fato indica um aumento da rigidez deste solo, ou seja, a tensão de ruptura foi atingida para menores deformações. Para as amostras do solo Botucatu, a deformabilidade situa-se dentro de uma faixa que varia entre $1,44 \%$ e $-39,3 \%$, enquanto que para a mistura a amplitude desta faixa aumentou-se de $-15 \%$ para $64,7 \%$. O aumento desta variação pode ser um indicativo de uma maior influência do contaminante na mistura do que no solo Botucatu, porém, poucos resultados impossibilitam tirar maiores conclusões.

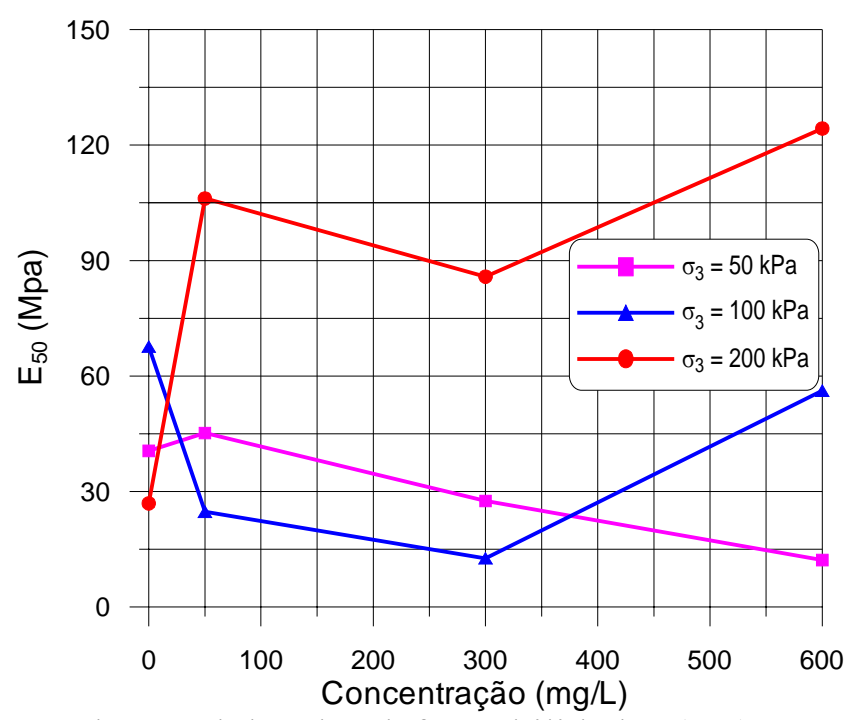

Figura 6.11. Variação do módulo de deformabilidade $\left(E_{50}\right)$ com a concentração de contaminante para o solo Serra Geral. 


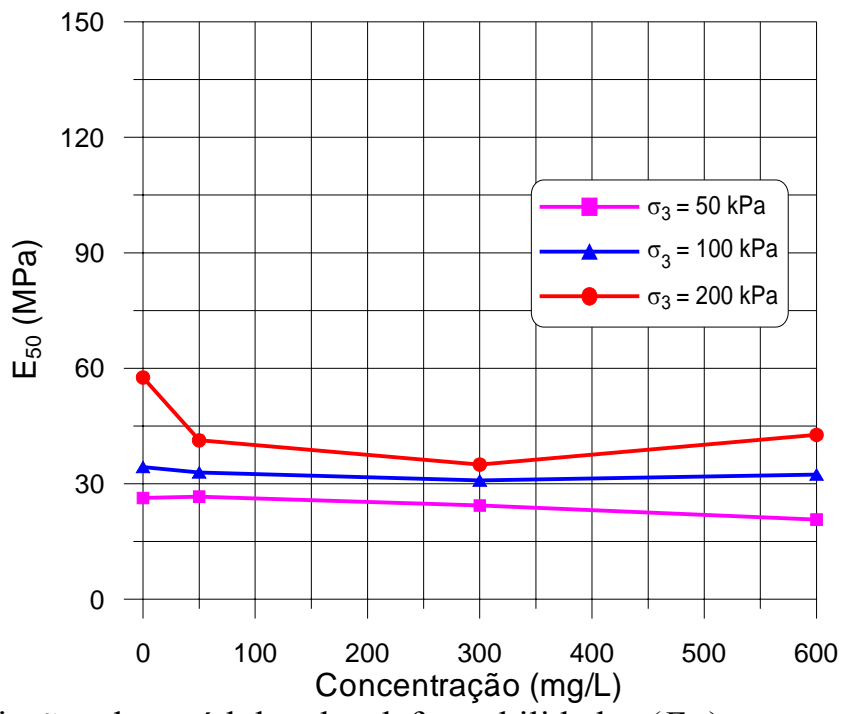

Figura 6.12. Variação do módulo de deformabilidade $\left(E_{50}\right)$ com a concentração de contaminante para o solo Botucatu.

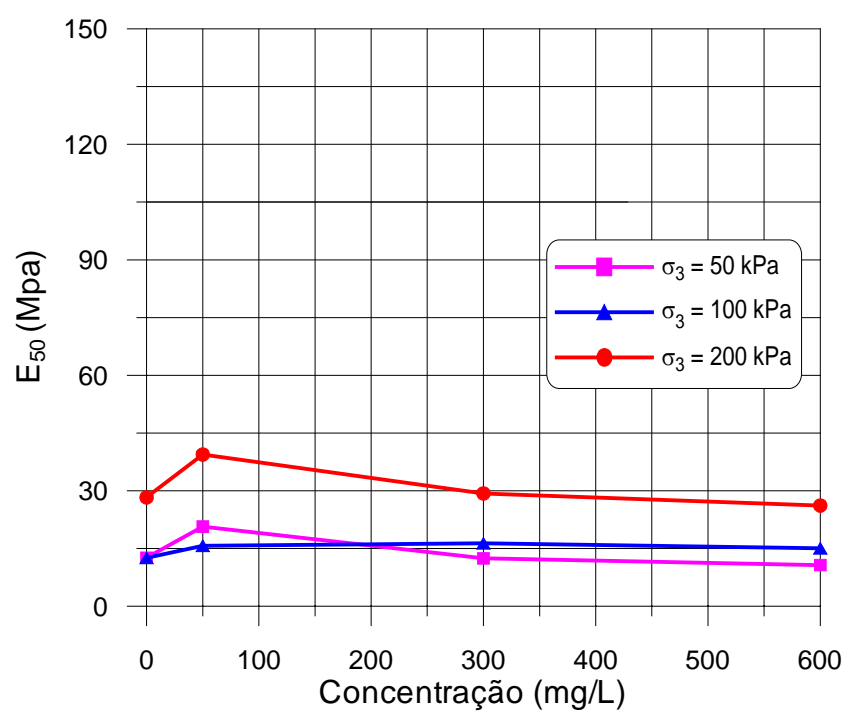

Figura 6.13. Variação do módulo de deformabilidade $\left(E_{50}\right)$ com a concentração de contaminante para a mistura. 


\subsection{CONCLUSÕES}

As curvas de chegada obtidas para os íons cobre $\left(C u^{+2}\right)$ e cloreto $\left(C l^{-1}\right)$ comprovaram que a maior atenuação da solução contaminante ocorreu para o solo Serra Geral, em seguida para a mistura e, por último, para o solo Botucatu. O aumento da concentração iônica dos íons cobre gerou uma diminuição da capacidade sorciva do solo Serra Geral e da mistura.

O processo de atenuação dos contaminantes através do solo, mais especificamente, pela fração fina do solo, pode estar relacionado ao fenômeno da dupla camada elétrica. Tal processo, provocado pelo desequilíbrio de cargas entre o solo (partículas finas carregadas eletricamente) e a solução contaminante, é responsável por alterar o comportamento do solo quanto ao arranjo da sua estrutura, e conseqüentemente, as suas características de condutividade hidráulica e resistência.

Para os solos argilosos Serra Geral, a resistência foi significativamente afetada, apresentando uma redução máxima na tensão de ruptura da ordem de $43 \%$ para a concentração de $600 \mathrm{mg} / \mathrm{L}$ e confinamento $50 \mathrm{kPa}$. A mistura apresentou redução máxima de $25,1 \%$ na tensão de ruptura para a concentração de $600 \mathrm{mg} / \mathrm{L}$ e confinamento de $50 \mathrm{kPa}$, enquanto que para o solo Botucatu a redução máxima foi de 7,9\% para as mesmas condições.

Para os três solos analisados, observou-se que a queda de resistência dos solos foi mais acentuada para os corpos de prova percolados com maiores concentrações (300 e $600 \mathrm{mg} / \mathrm{L}$ ) e confinados com menores tensões confinantes. $\mathrm{O}$ aumento da concentração da solução contaminante pode ter provocado a redução da espessura da dupla camada elétrica, aumentando a força atrativa entre as partículas. Esta condição pode promover a floculação das partículas argilosas, e, conseqüentemente, aumentar o volume de vazios do solo. Esta mudança na estrutura interna do solo pode ser responsável pelo acréscimo na condutividade hidráulica $(k)$ e diminuição na resistência ao cisalhamento do solo.

Em relação aos parâmetros de resistência, as maiores reduções, tanto para a coesão total quanto para a efetiva, também estão relacionadas ao solo Serra Geral. Porém, 
constatou-se que não houve variação significativa no ângulo de atrito total e efetivo, para os três solos estudados.

De maneira geral, os poucos resultados de módulo de deformabilidade $\left(E_{50}\right)$ não possibilitaram uma análise especifica da influência da contaminação neste parâmetro. A difícil determinação deste módulo pode ser relacionada a imperfeições das amostras, decorrentes de problemas de compactação.

Da análise dos três solos para utilização em liners, confirmou-se que o solo Serra Geral (baixa resistência) e o solo Botucatu (alta condutividade hidráulica) podem apresentar problemas quando utilizados isoladamente. A mistura na dosagem pré-definida apresentou comportamento mais adequado, tornando-se uma alternativa interessante para esta finalidade.

\subsection{SUGESTÕES PARA CONTINUIDADE}

A Revisão Bibliográfica desenvolvida demonstrou que o estudo sobre o comportamento dos solos tropicais, frente aos contaminantes, envolve vários fatores e está longe de estar concluído. A importância destes solos se deve a sua grande abundância no território brasileiro. Assim, sugere-se o desenvolvimento de novas pesquisas nesta área para aumentar o nível de conhecimento sobre as propriedades destes solos potenciais para utilização em liners.

Para dar continuidade à linha de pesquisa existente no Departamento de Geotecnia da EESC-USP, apresentam-se a seguir, algumas sugestões pertinentes para a realização de trabalhos futuros:

- Avaliar a influência de outro contaminante, por exemplo, o íon potássio $\left(\mathrm{K}^{+}\right)$, na resistência ao cisalhamento de solos para utilização como liners. Assim, o banco de dados sobre a influência de contaminantes na resistência ao cisalhamento de solos será mais representativo em relação aos íons mais comuns encontrados nos líquidos oriundos da decomposição de resíduos e que podem causar efeitos tóxicos aos seres vivos.

- Estudar o comportamento de uma mistura constituída de $40 \%$ de solo Serra Geral e $60 \%$ de solo Botucatu, já que a mistura 20\% - 80\% apresentou valores de condutividade hidráulica próximos e pouco inferior a $10^{-9} \mathrm{~m} / \mathrm{s}$. Desta forma, dependendo da periculosidade do resíduo, a sua utilização pode não ser aceita. Neste sentido, o conhecimento da influência da contaminação na mistura $40 \%-60 \%$ pode ser interessante. 
- Para agilizar a realização dos ensaios e minimizar as perdas de colunas de solo compactado sugere-se que o equipamento de percolação sofra adaptações, principalmente quando o objetivo do trabalho for realizar ensaios triaxiais em solos contaminados. As mudanças sugeridas são: (1) alterar as dimensões das colunas, passando-as para dimensões compatíveis com os corpos de prova triaxiais. Tal fato deve aumentar a velocidade do ensaio de percolação e evitar a realização do processo de talhagem e (2) confeccionar as colunas de forma bi-partida para facilitar a retirada das amostras, principalmente para os solos compostos com alto teor de argila. Esta modificação deve evitar perda de corpos de prova durante sua extração e destruição das colunas, evitando cortá-las.

- Em virtude da dificuldade da avaliação do efeito da contaminação na deformabilidade, sugere-se que ao analisar este parâmetro, aumente-se o espaço amostral (maior número de corpos de provas) na tentativa de quantificá-lo de forma mais satisfatória. 


\section{REFERÊNCIAS BIBLIOGRÁFICAS}

ALPHA STANDARD METHODS (1995) Standard Methods for the Examination of Water and Wastewater - Method 4500 - Cl. Americam Public Health Association, Washington D.C, $19^{\text {th }}$, pp. $4-45$.

AL-SANAD, H.A.; ISMAEL,N.F. (1995) Geotechnical Properties of Oil - Contaminated Sand. J. Geotechnical and Geoenvironmental Engineering, ASCE, V. 121 (5), pp. $407-$ 411.

AL-SANAD, H.A.; ISMAEL,N.F. (1997) Aging Efects on Oil - Contaminated Kuwait Sand. J. Geotechnical and Geoenvironmental Engineering, ASCE, V. 123 (3), pp. 290 - 293.

AMERICAN SOCIETY FOR TESTING AND MATERIALS (1998) Standard Test Method for Specific Gravity of Soils - D-854. ASTM International, West Conshohocken, Pennsylvania, USA.

AMERICAN SOCIETY FOR TESTING AND MATERIALS (1995) Standard Test Method for Consolidated Undrained Triaxial Compression Test for Cohesive Soils - D-4767. ASTM International, West Conshohocken, Pennsylvania, USA.

ASSOCIAÇÃO BRASILEIRA DE NORMAS TÉCNICAS (1992) Apresentação de Projetos de Aterros de Resíduos Sólidos Urbanos (NBR 8419), Rio de Janeiro.

ASSOCIAÇÃO BRASILEIRA DE NORMAS TÉCNICAS (1984) Peneiras para Ensaio EB-22 (NBR 5734/80), Rio de Janeiro.

ASSOCIAÇÃO BRASILEIRA DE NORMAS TÉCNICAS (1987) Resíduos Sólidos:

Classificação (NBR 10004), Rio de Janeiro. 
ASSOCIAÇÃO BRASILEIRA DE NORMAS TÉCNICAS (1995) Rochas e Solo (NBR 6502), Rio de Janeiro.

ASSOCIAÇÃO BRASILEIRA DE NORMAS TÉCNICAS (1984) Solo - Análise Granulométrica - MB - 32 (NBR 7181), Rio de Janeiro.

ASSOCIAÇÃO BRASILEIRA DE NORMAS TÉCNICAS (1984) Solo - Determinação do Limite de Plasticidade - MB -31 (NBR 9180), Rio de Janeiro.

ASSOCIAÇÃO BRASILEIRA DE NORMAS TÉCNICAS (1984) Solo - Determinação do Limite de Liquidez - MB - 30 (NBR 6459), Rio de Janeiro.

ASSOCIAÇÃO BRASILEIRA DE NORMAS TÉCNICAS (1984) Solo - Ensaio de Compactação - MB - 33 (NBR 7182), Rio de Janeiro.

BALERINI, C. (2000) Saneamento: Tratar o Lixo para Preservar o Planeta. Revista Ecologia e desenvolvimento, edição 88.

BARDET, J.P. (1997) Experimental Soil Mechanics. Prentice Hall, New Jersey.

BASSO, J.B. (2003) Transporte e Retenção de $\mathrm{K}^{+}, \mathrm{Cu}^{+2}$ e $\mathrm{Cl}^{-}$em uma Mistura Compactada de Solos Lateríticos para Uso em Barreiras Selantes: Procedimento de Homogeneização da Mistura e Adaptações em Equipamento de Percolação em Colunas. Dissertação de Mestrado, Escola de Engenharia de São Carlos, Universidade de São Paulo, 168 p.

BEDIENT, P.B; RAFAR, H.L; NEWELL, C.J (1994) Ground Water Contamination Transport and Remediation. Prentice Hall, New York, 541 p.

BENSON, C.B; DANIEL, D.E. (1990) Infuence of Clods on Hydraulic Conductivity of Compacted. Journal of Geotechnical Engineering, V.120 (10), pp. 1704-1725. 
BENSON, C.H.; DANIEL, D.E. (1994) Minimum Thickness of Compacted Soil Liners: I. Stochastic Models. J. Geotech. Engineering, ASCE, V.120 (1), pp. 131-171.

BENSON, C.H.; ZHAI, H.; WANG, X. (1994) Estimating the Hydraulic Conductivity of Compacted Clay Liners. J. Geotech. Engineering, ASCE, V.120 (2), pp. 366-387.

BIDONI, F.R.A; POVINELLI, J. (1999) Conceitos Básicos de Resíduos Sólidos. Escola de Engenharia de São Carlos, Universidade de São Paulo, Projeto REENGE, 109 p.

BOFF, F.E (1999) Avaliação do comportamento de uma mistura compactada de solos lateríticos frente a soluções de $\mathrm{Cu}^{+2}, \mathrm{~K}^{+}$e $\mathrm{Cl}^{-1}$ em colunas de percolação. Dissertação de Mestrado, Escola de Engenharia de São Carlos, Universidade de São Paulo, 180 p.

BRANDL, H. (1992) Mineral Liners for Hazardous Waste Containment. Geotéchnique, V.42 (1), pp 57-65.

BUENO, B.S.; VILAR, O.M. (1997) Mecânica dos Solos. Escola de Engenharia de São Carlos, Universidade de São Paulo, V.1, 131 p.

CAMARGO, O.A.; MONIZ, A.C.; JORGE, J.A.; VALADARES, J.M.A.S. (1986) Métodos de Análise Química, Mineralógica e Física de Solos do Instituto Agronômico de Campinas. Campinas, Instituto Agronômico, 94 p.

CETESB - COMPANHIA DE TECNOLOGIA E DE SANEAMENTO AMBIENTAL DE SÃO PAULO. (1993) Resíduos Sólidos Industriais. São Paulo - SP.

CLEARY, R.W.(1991) Qualidade da Água Subterrânea. In: Porto, R.L.L (org). Hidrologia Ambiental. São Paulo, Editora da Universidade de São Paulo, pp. 211-293.

CONAMA - CONSELHO NACIONAL DO MEIO AMBIENTE. (1986) Resolução CONAMA N² 20, 18 de junho de 1986, publicado no D.O.U. de 30/07/86. 
CORRÊA, A.C.; SOUZA, N.M.(2002) Alteração das Características dos Solos Tropicais Submetidos Contaminação por Chorume. XII Congresso Brasileiro de Mecânica dos Solos e Engenharia Geotécnica, V. 02, pp. 739-747.

COSTA JÚNIOR, F. A (2001) Estudo da Influência da Infiltração de Soda Cáustica nas Características de Resistência de um Solo Laterítico. Dissertação de Mestrado, Pontifícia Universidade Católica do Rio de Janeiro, 87 p.

CRAIG, R.F (1992) Soil Mechanics. Chapman \& Hall, London, Fifth Edition, 427 p.

DANIEL, D.E. (1993) Clay Liners. In: DANIEL, D.E. Geotechnical Pratice for Waste Disposal. Chapman \& Hall, London, Chapter 1, pp. 3-14.

DAY, S; DANIEL, D.E. (1985) Hydraulic Conductivity of Two Prototype Clay Liners. J. Geotech. Engineering, ASCE, V.111(8), pp. 957-970.

FARINHA, F.J.B. (1998) Alguns Princípios de Dimensionamento do Sistema Basal de Selagem em Aterros Sanitários. Geotecnia, Lisboa, n 84, pp. 67-74.

FREEZE, R.A.; CHERRY, J.A. (1979) Groundwater. Englewood Cliffs NJ, Prentice Hall, $604 \mathrm{p}$.

HEAD, K. (1986) Manual of Soil Laboratory Testing. V. 03. Pentech Press, London, 712 p.

INSTITUTO DE PESQUISA TECNOLÓGICA - IPT (1995) Lixo municipal: Manual de Gerenciamento Integrado. CEMPRE , 278 p.

IZZO, R. L. S. (2003) Influência da Contaminação por Cloreto de Cobre na Resistência de um Solo Arenoso Compactado. Dissertação de mestrado, Universidade Estadual Paulista Bauru, 143 p. 
KRAUSCOPF, K.B. (1972) Introdução a Geoquímica. São Paulo. Editora da Universidade de São Paulo, 294 p.

LAMBE, T.W (1958) The Structure of Compacted Clay. Journal of the Soil Mechanics and Foundations. Division SM2, n 1654, pp. 1-34.

LAMBE, T. ;WHITMAN, R.V. (1979) Soil Mechanics - Version SI. John Wiley \& Sons, New York, 553 p.

LEITE, A.L. (1997) A Difusão Molecular do $\mathrm{K}^{+}$e Cl em Solos Naturais Compactados: Uma Perspectiva para Uso em Liners. Dissertação de Mestrado, Escola de Engenharia de São Carlos, Universidade de São Paulo.

LEITE, A.L. (2001) Migração de Íons Inorgânicos em Alguns Solos Tropicais, com Ênfase nos Processos de Sorção e Difusão Molecular. Tese de Doutorado, Escola de Engenharia de São Carlos, Universidade de São Paulo, 254 p.

LEITE, J.C. (1995) Metodologia Para a Elaboração da Carta de Susceptibilidade à Contaminação e Poluição das Águas Subsuperficiais. Dissertação de Mestrado, Escola de Engenharia de São Carlos, Universidade de São Paulo, 110 p.

LEITE, J.C. (2000) Estudos Laboratoriais de Percolação em Colunas de Misturas compactadas: Equipamentos e Ensaios. Tese de Doutorado, Escola de Engenharia de São Carlos, Universidade de São Paulo, 223 p.

LEITE, J.C.; ZUQUETTE, L. (1995) Prevenção da Contaminação e Poluição de Aqüiferos: A Utilização de Liners. Boletim de Geociências, São Paulo, V.14 (1), pp. 167-178.

LEITE, J.C.; PARAGUASSÚ, A.B., ZUQUETTE, L.V. (1998) An equipament for percolation test in soil columns. In: International Congress on Environmental Geotechnics, $4^{\text {th }}$, Lisboa, Portugal, Anais, V.1, pp. 211-215. 
LEITE, W.C.A. (1991) Estudo do Comportamento da Temperatura, pH e Teor de Umidade na Decomposição de Resíduos Sólidos Urbanos em Aterros Sanitários. Dissertação de Mestrado, Escola de Engenharia de São Carlos, Universidade de São Paulo, 114 p.

LIU, Z.G.; DING, C.P.; WU, Y.X.; PAN, S.Z.; XU, R.K. (1997) Oxidation - Reduction Reactions, Chemistry of Variable Charge Soils. New York, Oxford University, pp. 442 471.

LUNDGREN, L. (1986) Environmental Geology. New Jersey, Prentice Hall, 576 p.

MACAMBIRA, I. (2002) Avaliação do Comportamento de Solos do Estado de São Paulo como liners para aterros sanitários. Dissertação de mestrado, Escola de Engenharia de São Carlos, Universidade de São Paulo,132 p.

MATHESS, G.; PEKDEGER, A; SCHROTER, J. (1985) Behavior of Contaminants in Groundwater. In. Theorical Background, Hydrogeology and practice of Groundwater Prediction Zones. UNESCO/INGS/HEISE. V.06, pp.1-86.

MELFI, A.J. (1994) Lateritas e Processos de Laterização. Escola de Engenharia de São Carlos, Universidade de São Paulo, 29 p.

MITCHELL, J.K. (1991) Conduction Phenomena. Geotechnical pratice.

MITCHELL, J.K. (1993) Fundamentals of Soil Behavior. John Wiley \& Sons, NewYork.

NOGAMI, J.C; VILLIBOR, D.F. (1995) Pavimentação de Baixo Custo com Solos Lateríticos. São Paulo, 240 p.

NOGUEIRA, J.B. (1995) Mecânica dos Solos - Ensaios de Laboratório. Escola de Engenharia de São Carlos, Universidade de São Paulo, 248 p. 
PEJON, O.P. (1992) Mapeamento Geotécnico Regional da Folha de Piracicaba - SP (escala 1:100.000): Estudo de Aspectos Metodológicos de Caracterização e de Apresentação de Atributos. Tese de Doutorado, Escola de Engenharia de São Carlos, Universidade de São Paulo.

PINTO, C.S (1998) Propriedades do Solo. Fundações Teoria e Prática. São Paulo, Editora Pini, 2 ${ }^{\text {a }}$ edição, pp. 641-690.

PINTO, C.S (2002) Curso Básico de Mecânica dos Solos. São Paulo, Oficina de textos, $355 \mathrm{p}$.

ROWE, R.K; QUIKLEY, R.M.; BOOKER, J.R. (1995) Clayey Barrier Systems for Waste Disposal Facilities. London, E \& FN SPON, 390 p.

SCHACKELFORD, C.D. (1993) Contaminant Transport. In: Daniel, D.E., Ed., Geotechnical Practice for Waste Disposal. London, Chapman \& Hall, pp. 33-65.

SHACKELFORD, C.D. (1994) Critical Concepts for Columm Testing. Journal of Geotechnical Engineering, V.120 (10), pp.1804 -1828.

SCHACKELFORD, C.D.; ROWE, R.K. (1998) Contaminant Transport modeling. In: Environmetal Geotechnics. Lisboa, Anais, Rotterdam Balkema, pp. 939-956.

SCHALCH, V.; WELLINGTON, C.A.L.; LUCIANA, P.G. (1990) Curso Sobre Gerenciamento de Resíduos Sólidos. ABES. Goiânia. 227 p.

SHARMA, H. D; LEWIS, S. P. (1994) Waste Containment Systems, Waste Stabilization, and Landfills - Design an Evaluation. John Wiley \& Sons, New York, 585 p.

SPARKS, D.L. (1986) Soil Physical Chemistry. Florida, CRC Press, 300 p. 
VARGAS, M (1977) Introdução à Mecânica dos Solos. São Paulo. São Paulo, Mcgraw - Hill do Brasil, Editora da Universidade de São Paulo, 509 p.

VILAR, O.M (2002) Resistência ao Cisalhamento. Escola de Engenharia de São Carlos, Universidade de São Carlos.

YONG, R.N; MOHAMED, A.M.O; WARKENTIM, B.P. (1992) Principles of Contaminant Transport in Soils. Amsterdam, Elsevier, 327 p. 


\section{A.1. CURVAS DE CHEGADA}

Para confirmar a ocorrência da completa atenuação do contaminante pelos solos estudados, são apresentadas as curvas de chegada para os íons $\mathrm{Cu}^{+2}$ e $\mathrm{Cl}^{-1}$. Estas curvas são obtidas a partir dos valores de concentração relativa $\left(C / C_{0}\right)$ versus os correspondentes valores de volume percolado (SHACKELFORD, 1994). De acordo com Cleary (1991), é conveniente que os valores dos volumes percolados $\left(V_{p}\right)$ sejam expressos em termos do fator $T_{p}$, que representa a relação entre o volume percolado e o volume de vazios do corpo de prova $\left(V_{v}\right)$. Assim, tem-se:

$$
T_{p}=\frac{V_{p}}{V_{v}}=\frac{q t}{n A H}
$$

onde:

$q=$ vazão que percola através da amostra de solo compactado;

$t=$ é o tempo decorrido entre uma coleta e outra do efluente;

$n=$ porosidade do solo;

$A$ = área da seção transversal do corpo de prova;

$H=$ altura do corpo de prova.

Como já mencionado, as determinações das concentrações dos íons $\mathrm{Cu}^{+2}$ e $C l^{-1}$, foram realizadas no Laboratório de Geotecnia Ambiental do Departamento de Geotecnia da EESC - USP. A partir dessas determinações, as curvas de chegada foram traçadas na forma de curvas de tendência polinomiais. Para facilitar a visualização, as curvas de chegada $\left(\mathrm{Cu}^{+2}\right.$ e $\mathrm{Cl}^{-1}$ ) são apresentadas no mesmo gráfico para cada coluna ensaiada. Para facilitar a apresentação deste APÊNDICE, os três solos são apresentados isoladamente. 


\section{A.2. CURVAS DE CHEGADA PARA O SOLO SERRA GERAL}

As nove amostras de solo Serra Geral (três para cada concentração de contaminante), foram identificadas da mesma forma como foi apresentado no Capítulo 4, ou seja:

- Concentração $50 \mathrm{mg} / \mathrm{L}$ : amostras 04, 05 e 06, representadas pelas curvas de chegada das Figuras A1, A2 e A3, respectivamente;

- Concentração 300 mg/L: amostras 07, 08 e 09, representadas pelas curvas de chegada das Figuras A4, A5 e A6, respectivamente;

- Concentração $600 \mathrm{mg} / \mathrm{L}$ : amostras 10, 11 e 12, representadas pelas curvas de chegada das Figuras A7, A8 e A9, respectivamente.

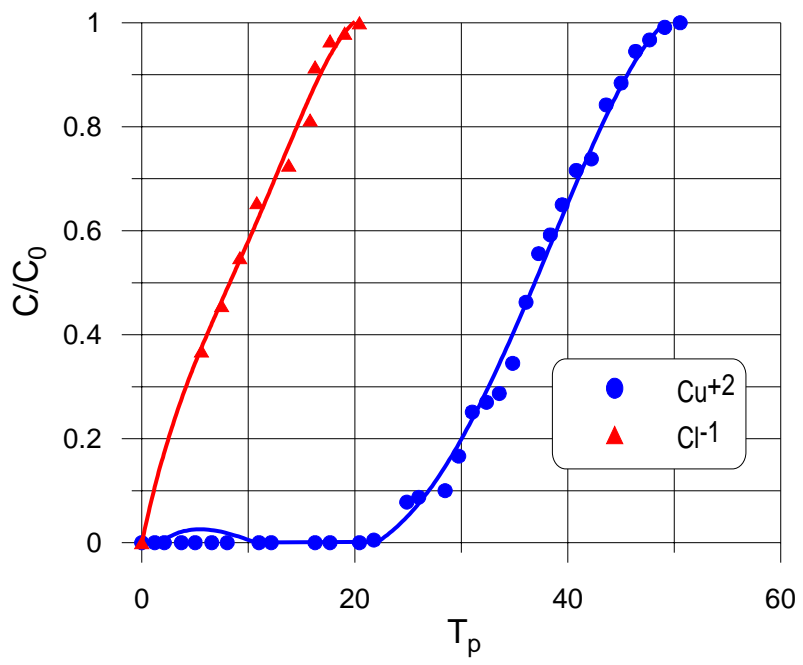

Figura A1. Curva de chegada para a amostra 04.

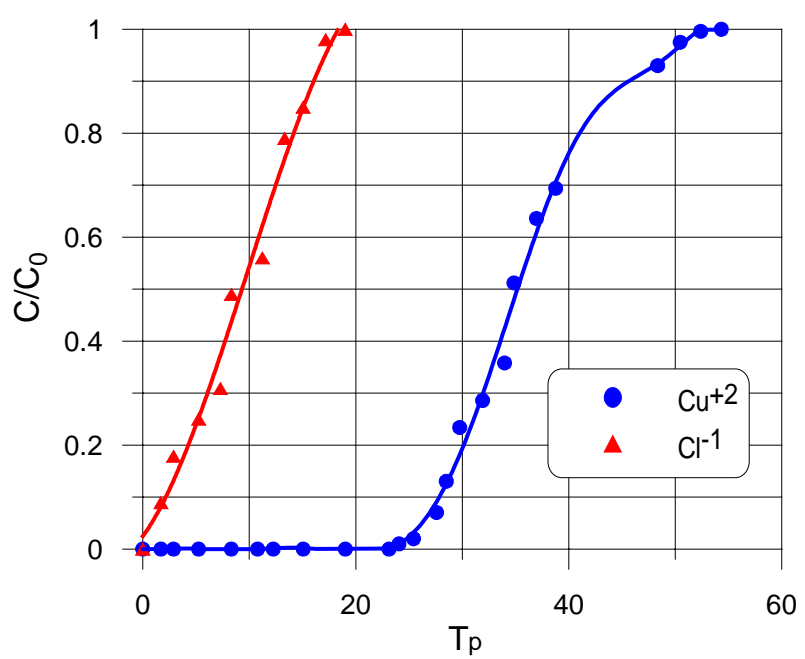

Figura A2. Curva de chegada para a amostra 05. 


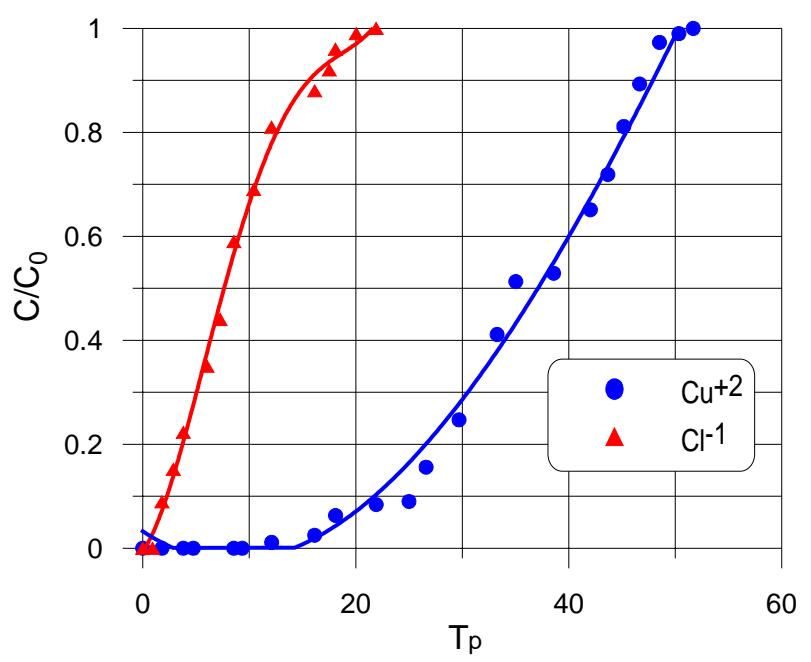

Figura A3. Curva de chegada para a amostra 06.

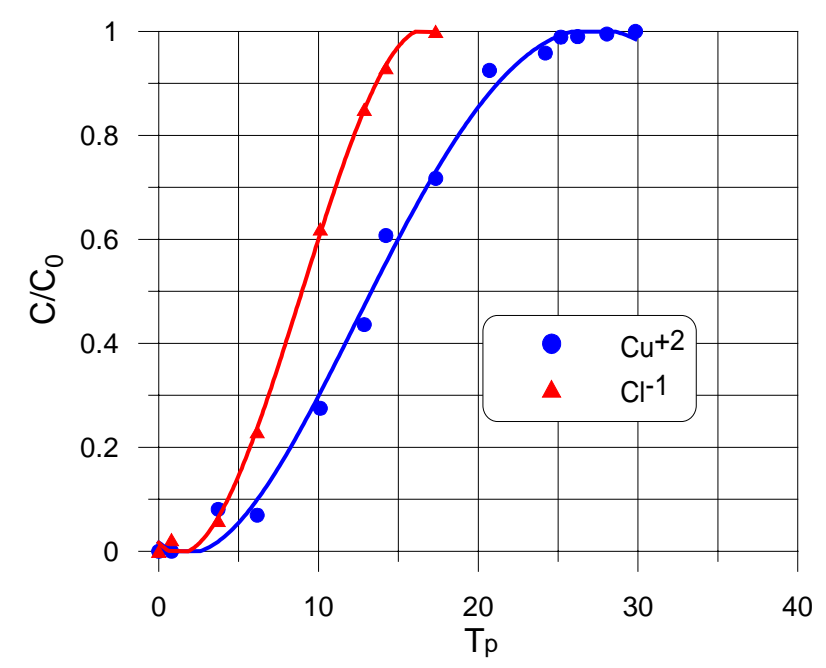

Figura A4. Curva de chegada para a amostra 07.

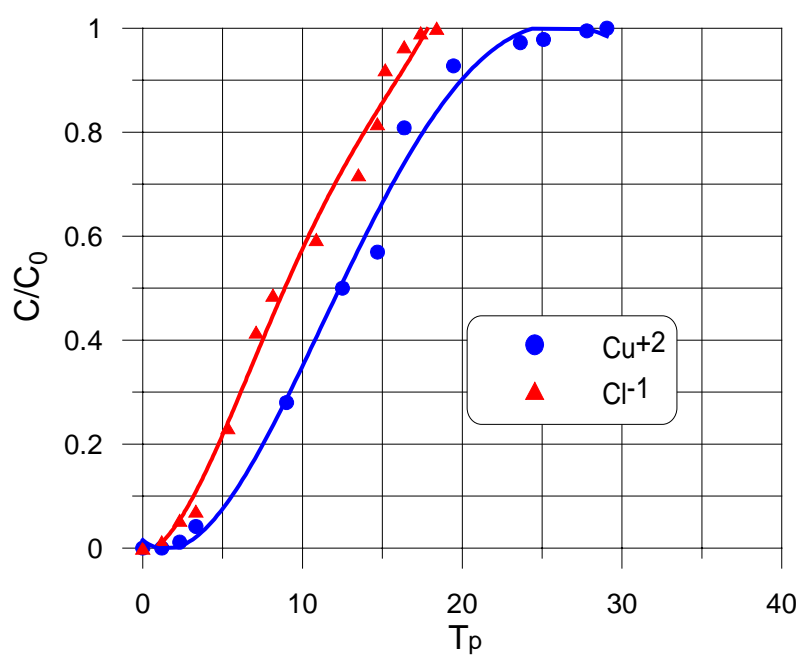

Figura A5. Curva de chegada para a amostra 08. 


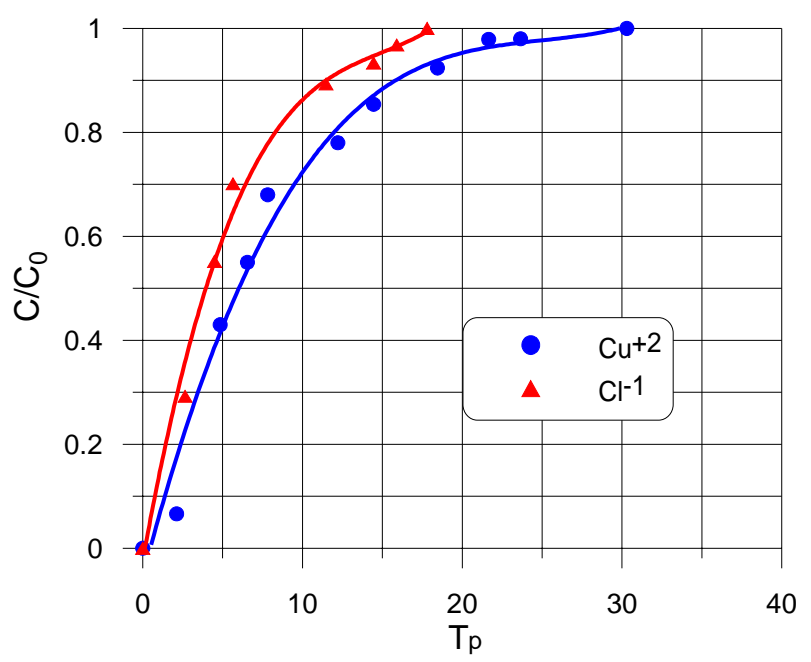

Figura A6. Curva de chegada para a amostra 09.

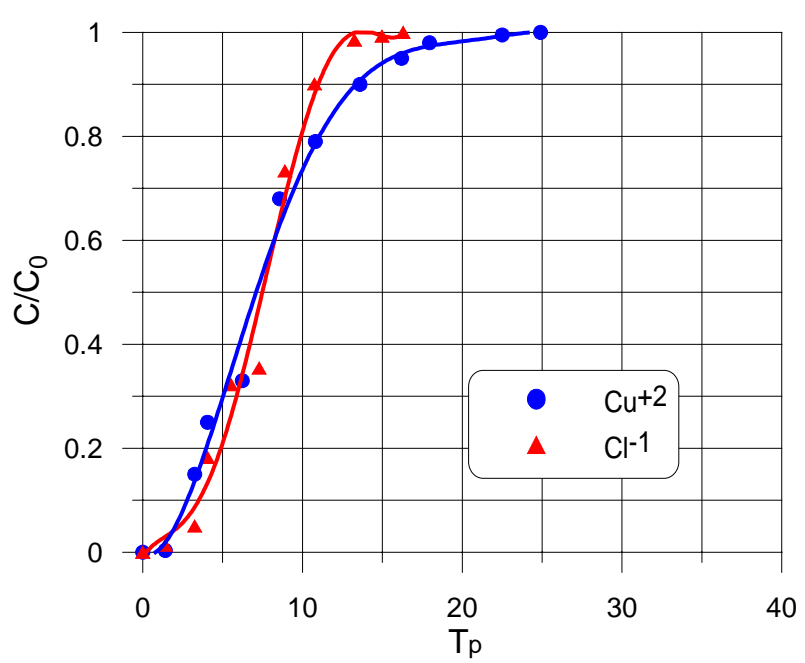

Figura A7. Curva de chegada para a amostra 10.

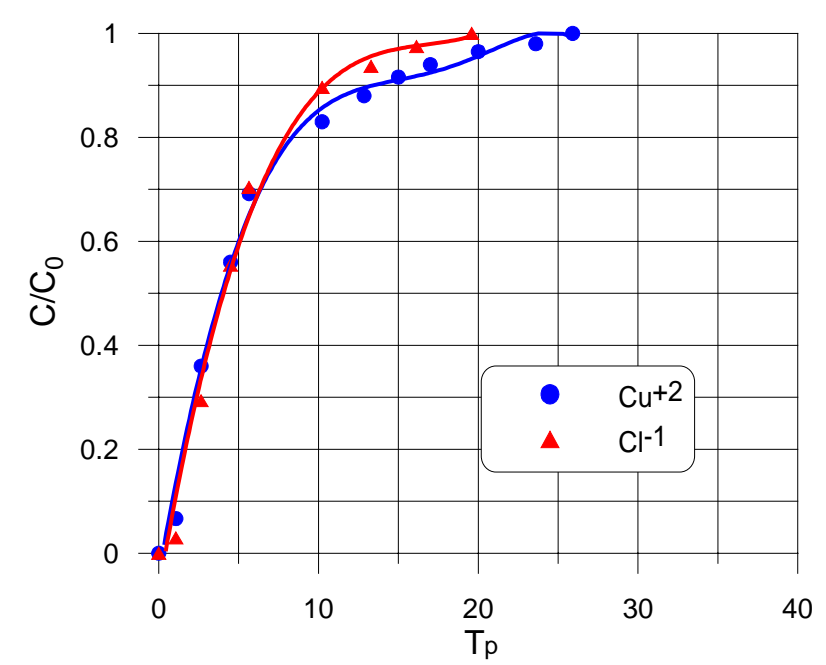

Figura A8. Curva de chegada para a amostra 11. 


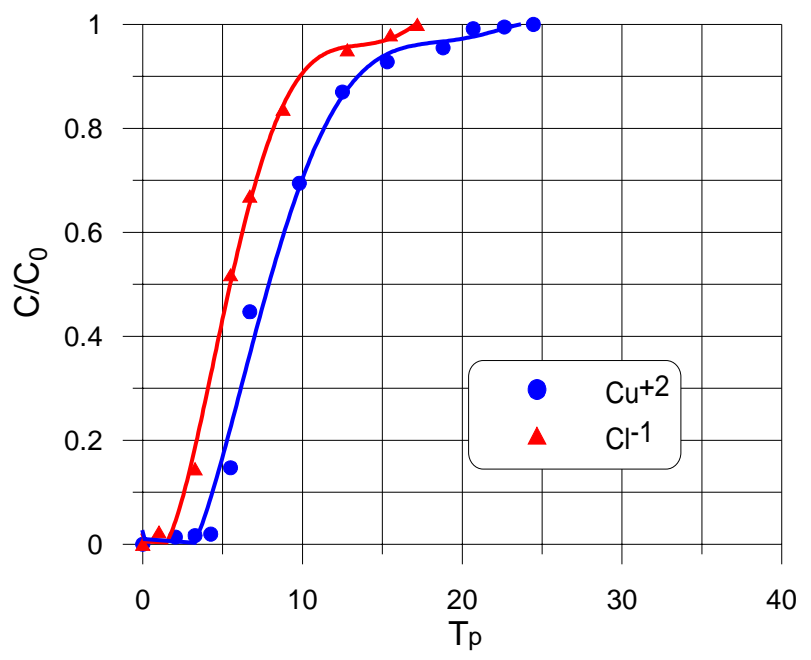

Figura A9. Curva de chegada para a amostra 12.

\section{A.3. CURVAS DE CHEGADA PARA O SOLO BOTUCATU}

As nove amostras de solo Botucatu (três para cada concentração de contaminante), foram identificadas da mesma forma como foi apresentado no Capítulo 4, ou seja:

- Concentração $50 \mathrm{mg} / \mathrm{L}$ : amostras 04, 05 e 06, representadas pelas curvas de chegada das Figuras A10, A11 e A12, respectivamente;

- Concentração $300 \mathrm{mg} / \mathrm{L}$ : amostras 07, 08 e 09, representadas pelas curvas de chegada das Figuras A13, A14 e A15, respectivamente;

- Concentração $600 \mathrm{mg} / \mathrm{L}$ : amostras 10, 11 e 12, representadas pelas curvas de chegada das Figuras A16, A17 e A18, respectivamente.

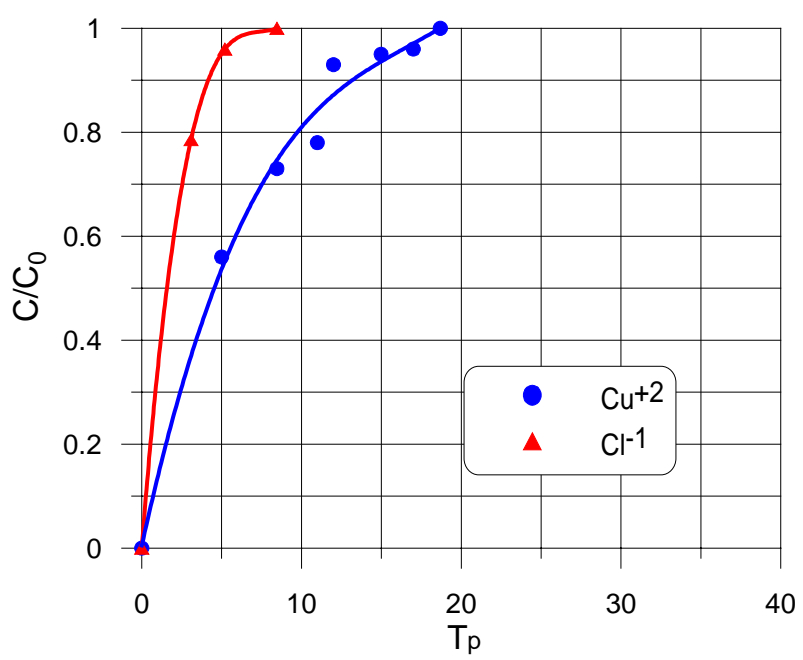

Figura A10. Curva de chegada para a amostra 04. 


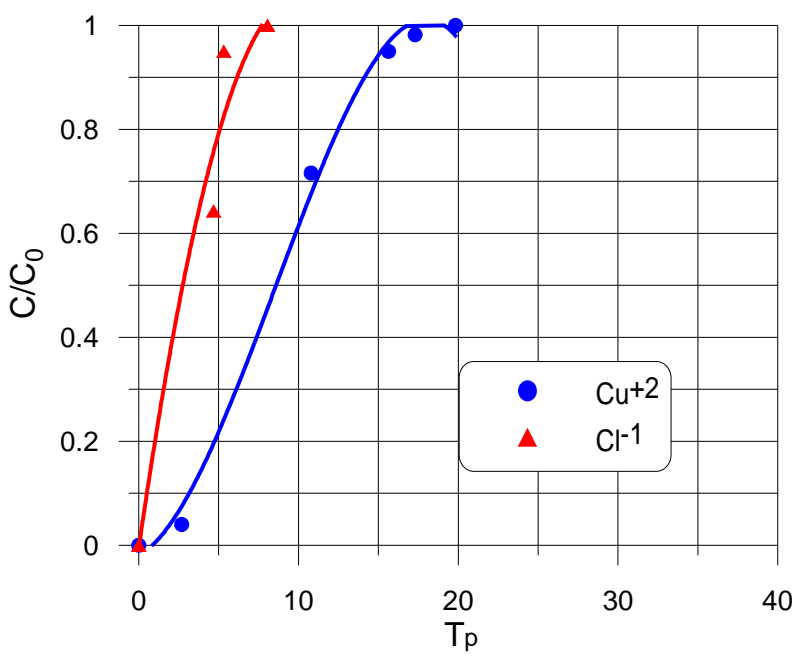

Figura A11. Curva de chegada para a amostra 05.

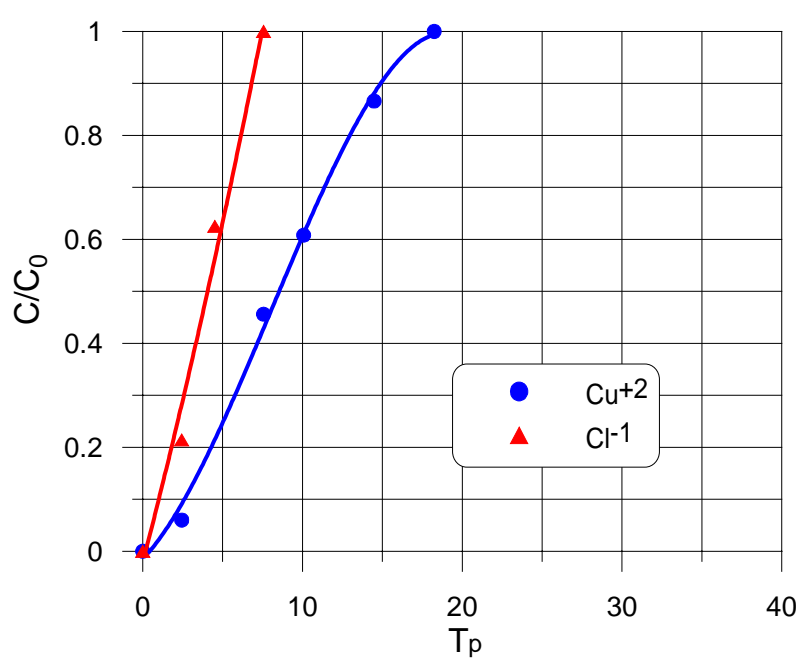

Figura A12. Curva de chegada para a amostra 06.

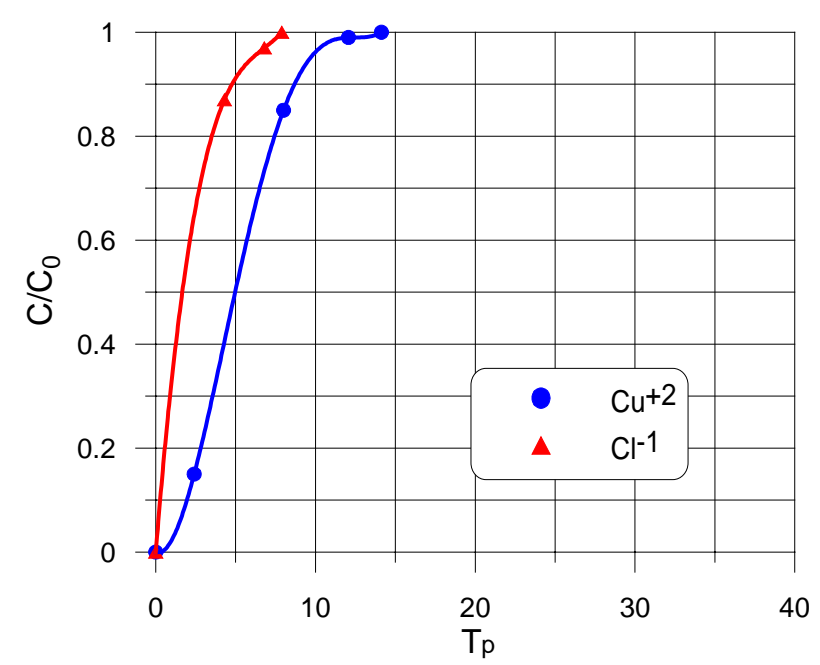

Figura A13. Curva de chegada para a amostra 07. 


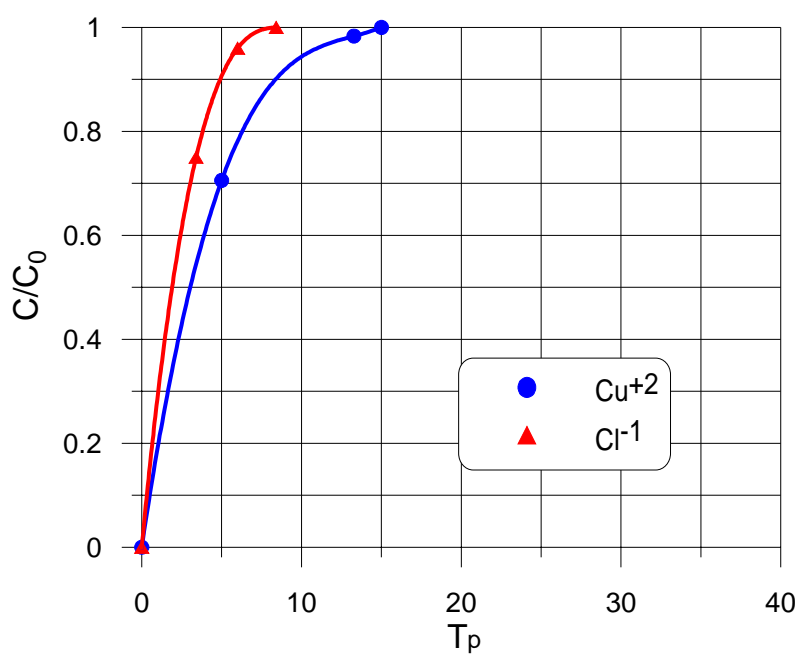

Figura A14. Curva de chegada para a amostra 08.

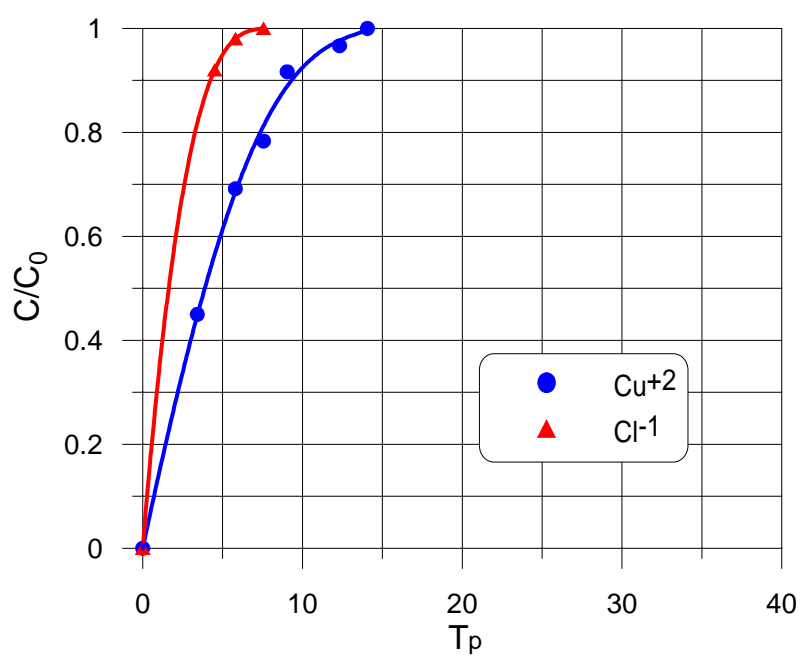

Figura A15. Curva de chegada para a amostra 09.

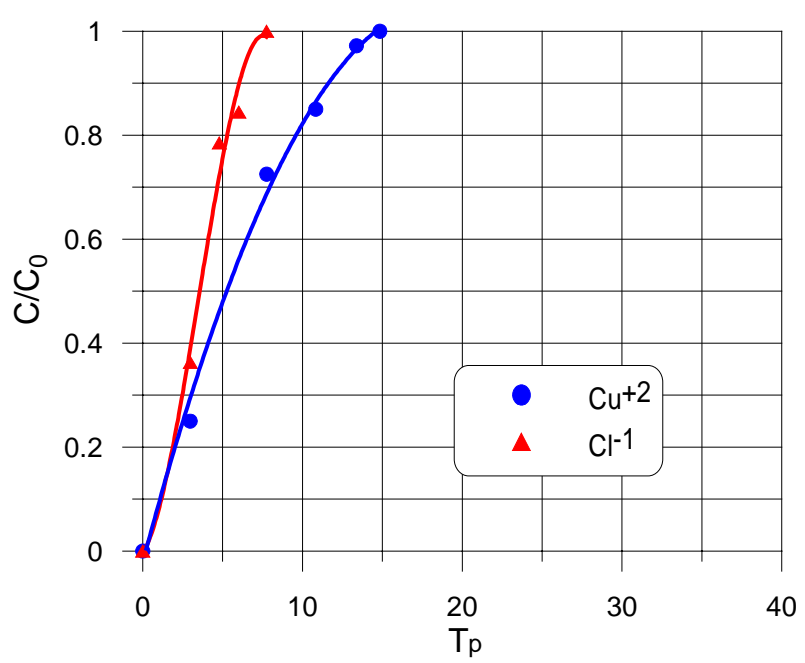

Figura A16. Curva de chegada para a amostra 10. 


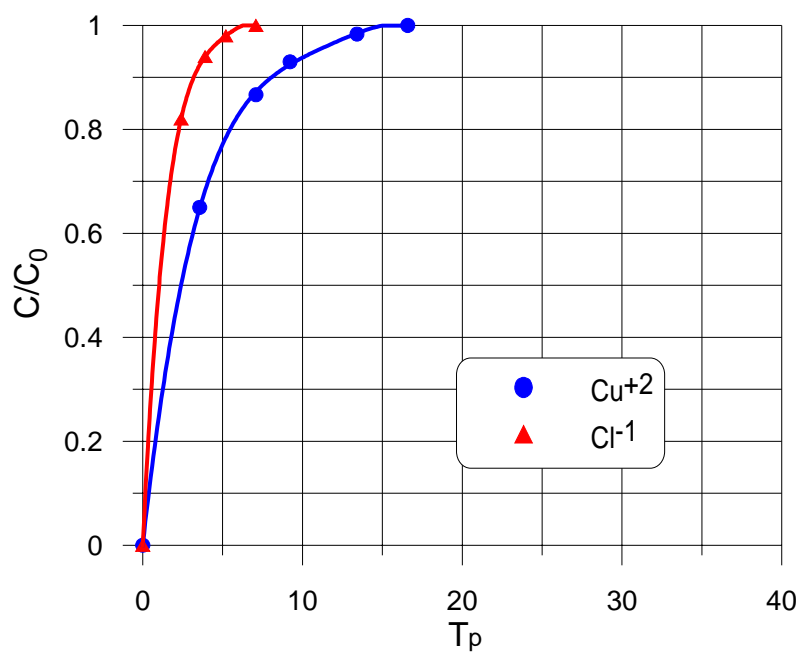

Figura A17. Curva de chegada para a amostra 11.

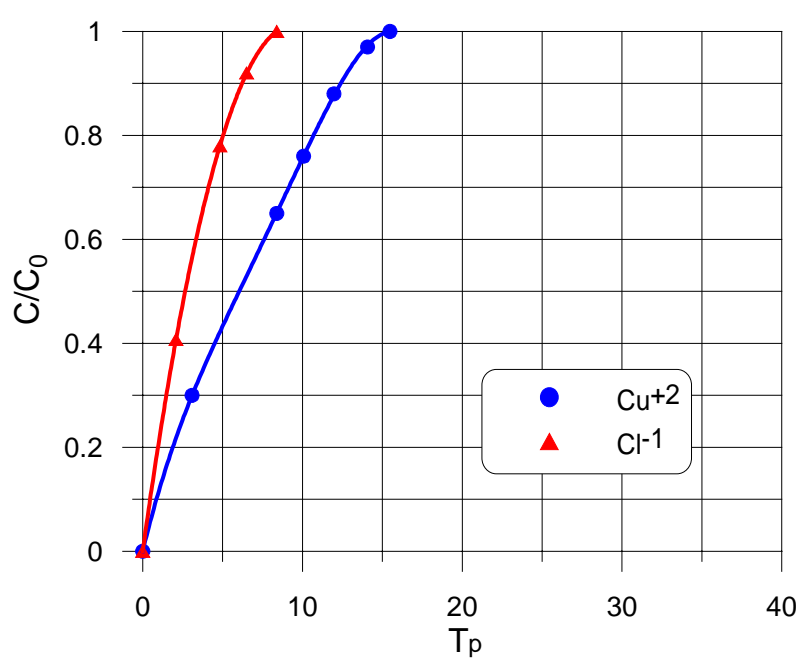

Figura A18. Curva de chegada para a amostra 12.

\section{A.4. CURVAS DE CHEGADA PARA A MISTURA 20\% - 80\%}

As nove amostras da Mistura 20\% - 80\% (três para cada concentração de contaminante), foram identificadas da mesma forma como foi apresentado no Capítulo 4, ou seja:

- Concentração $50 \mathrm{mg} / \mathrm{L}$ : amostras 04, 05 e 06, representadas pelas curvas de chegada das Figuras A19, A20 e A21, respectivamente;

- Concentração $300 \mathrm{mg} / \mathrm{L}$ : amostras 07, 08 e 09, representadas pelas curvas de chegada das Figuras A22, A23 e A24, respectivamente;

- Concentração 600 mg/L: amostras 10, 11 e 12, representadas pelas curvas de chegada das Figuras A25, A26 e A27, respectivamente. 


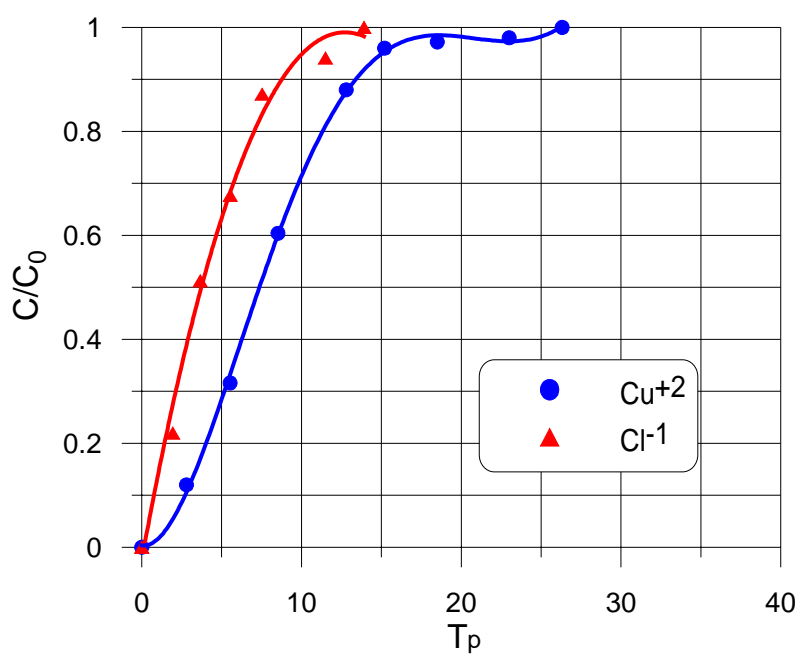

Figura A19. Curva de chegada para a amostra 04.

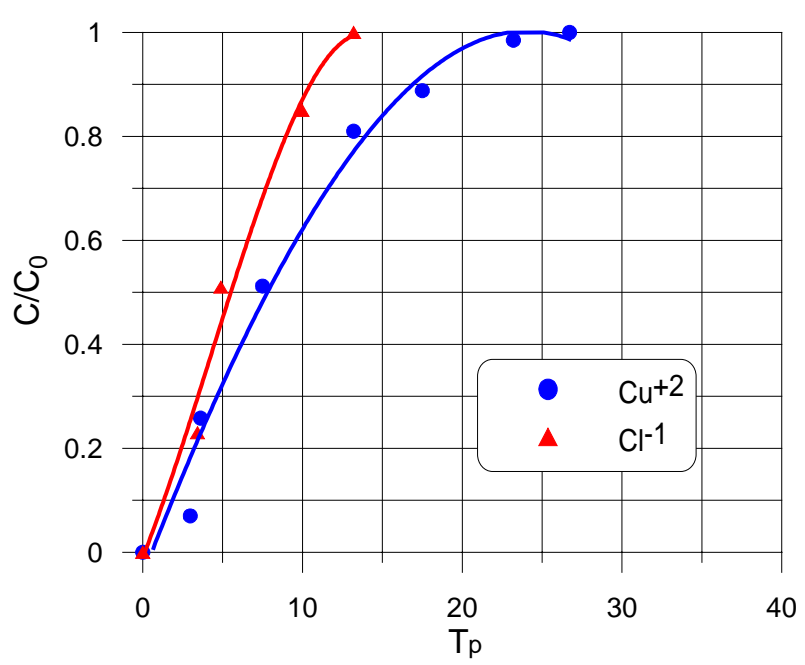

Figura A20. Curva de chegada para a amostra 05.

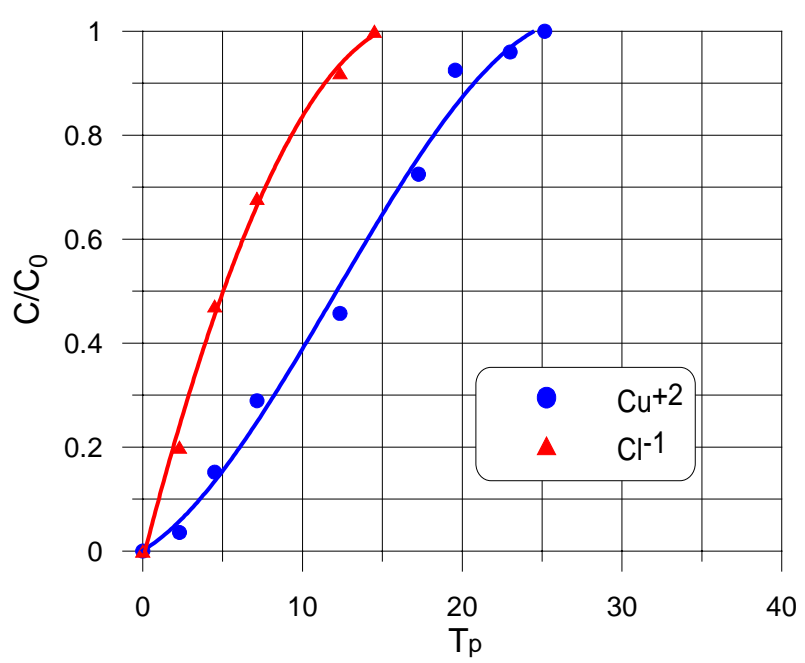

Figura A21. Curva de chegada para a amostra 06. 


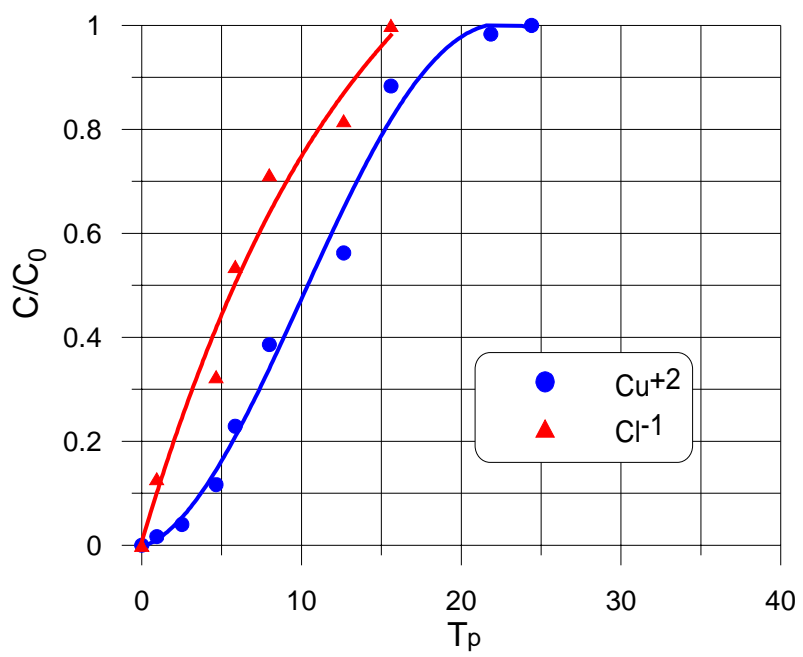

Figura A22. Curva de chegada para a amostra 07.

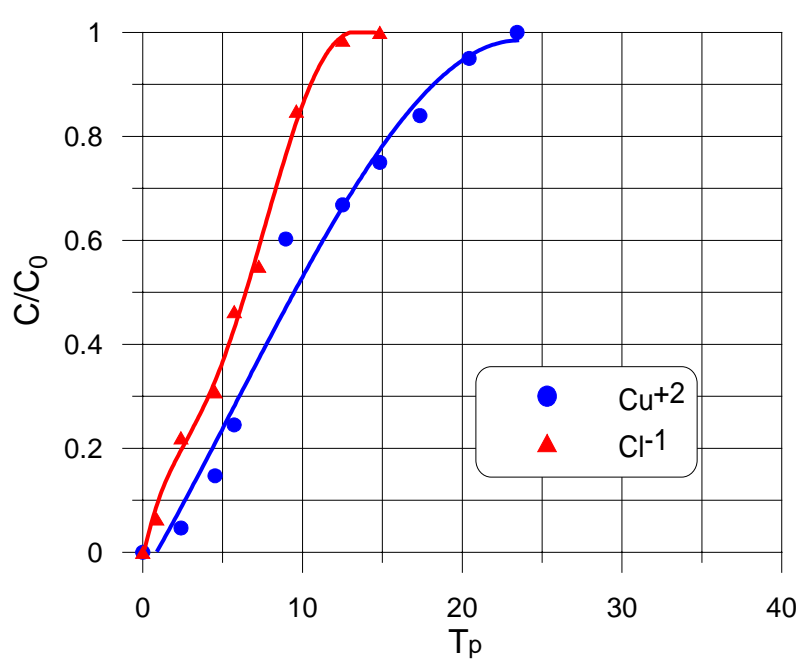

Figura A23. Curva de chegada para a amostra 08.

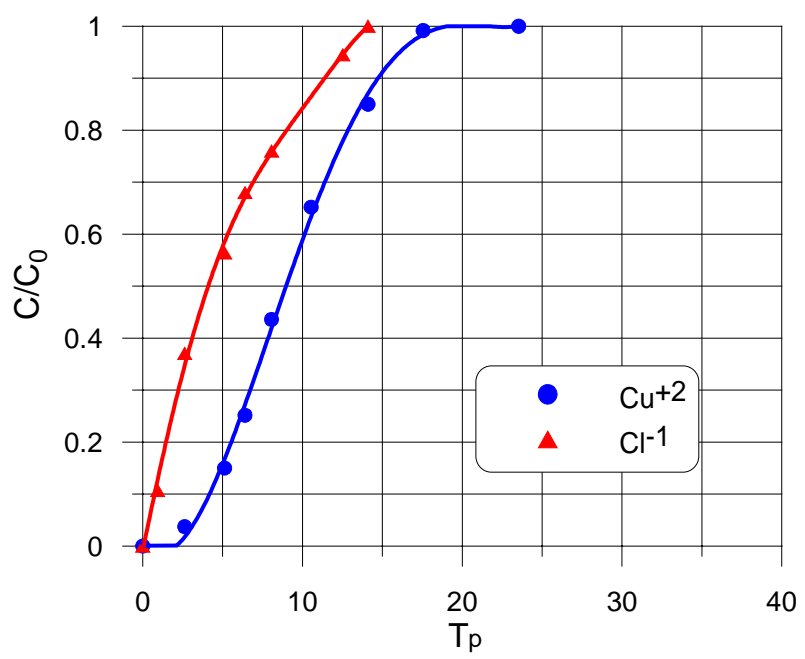

Figura A24. Curva de chegada para a amostra 09. 


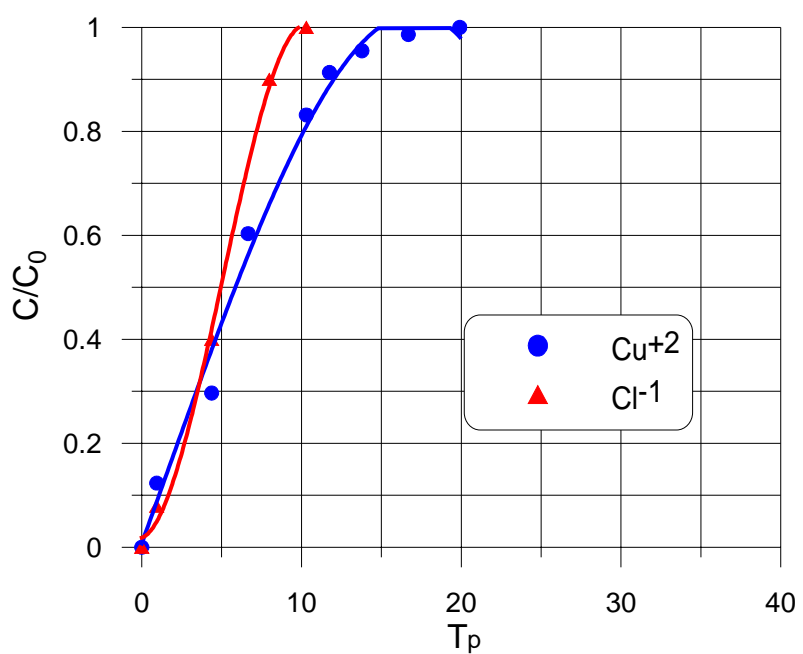

Figura A25. Curva de chegada para a amostra 10.

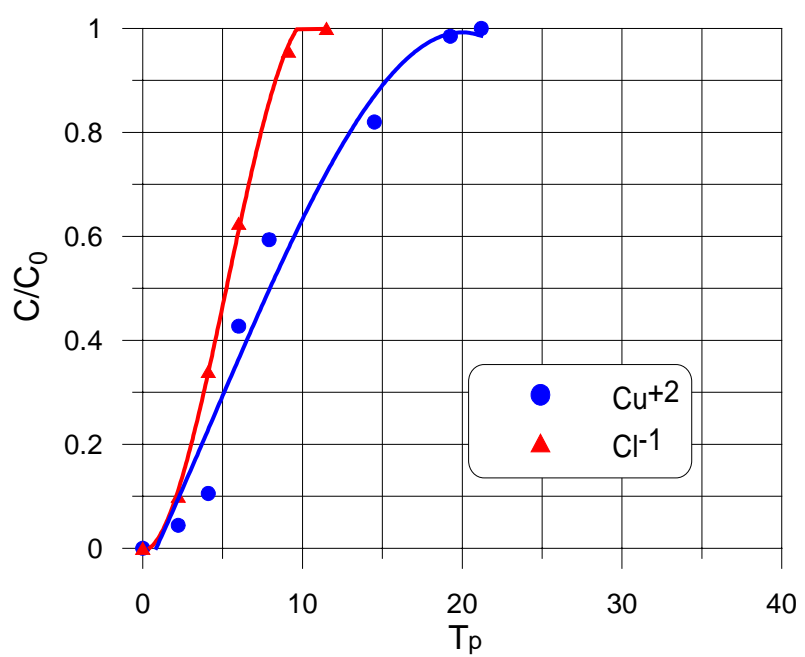

Figura A26. Curva de chegada para a amostra 11.

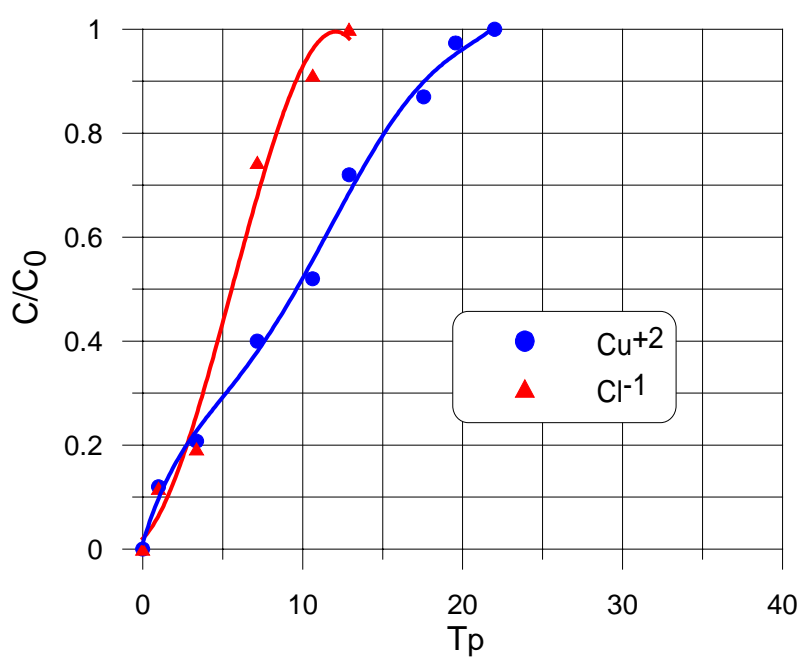

Figura A27. Curva de chegada para a amostra 12 